Fernando Anselmo de Oliveira

EFICÁCIA TERAPÊUTICA E MAPEAMENTO DAS CÉLULAS-TRONCO MEDULARES DE MURINOS JOVENS E IDOSOS MARCADAS COM NANOPARTÍCULAS EM MODELO DE TRANSPLANTE DE MEDULA ÓSSEA

Dissertação apresentada à Faculdade Israelita de Ciências da Saúde Albert Einstein para obtenção do título de Mestre em Ciências da Saúde.

São Paulo 
Fernando Anselmo de Oliveira

\title{
EFICÁCIA TERAPÊUTICA E MAPEAMENTO DAS CÉLULAS-TRONCO MEDULARES DE MURINOS JOVENS E IDOSOS MARCADAS COM NANOPARTÍCULAS EM MODELO DE TRANSPLANTE DE MEDULA ÓSSEA
}

\author{
Dissertação apresentada à Faculdade \\ Israelita de Ciências da Saúde Albert \\ Einstein para obtenção do título de Mestre \\ em Ciências da Saúde.
}

Orientador: Prof. Dr. Lionel Fernel Gamarra Contreras

Coorientador: Dr. Lucas Eduardo Botelho de Souza

São Paulo 


\section{Oliveira, Fernando Anselmo de \\ Eficácia terapêutica e mapeamento das células-tronco medulares de}

murinos jovens e idosos marcadas com nanopartículas em modelo de transplante de medula óssea / Fernando Anselmo de Oliveira. -- São Paulo, 2021.

xix, 103 f., il.

Dissertação (Mestrado) - Faculdade Israelita de Ciências da Saúde Albert Einstein. Instituto Israelita de Ensino e Pesquisa. Programa de Pós-Graduação em Ciências da Saúde.

Título em inglês: Therapeutic efficacy and mapping of bone marrow stem cells in young and aged mice labeled with nanoparticles in bone marrow transplantation model.

1. Nanopartículas. 2. Imagem de bioluminescência [não DeCS]. 3. Imagem de fluorescência [não DeCS]. 4. Imagem por ressonância magnética. 5. Célulastronco hematopoiéticas. 6. Transplante de medula óssea. 7. Imagem molecular.

Elaborada pelo Sistema Einstein Integrado de Bibliotecas 
FACULDADE ISRAELITA DE CIÊNCIAS DA SAÚDE ALBERT EINSTEIN

Coordenador do Curso de Pós-Graduação: Prof. Dr. Luiz Vicente Rizzo 
Fernando Anselmo de Oliveira

\title{
EFICÁCIA TERAPÊUTICA E MAPEAMENTO DAS CÉLULAS-TRONCO MEDULARES DE MURINOS JOVENS E IDOSOS MARCADAS COM NANOPARTÍCULAS EM MODELO DE TRANSPLANTE DE MEDULA ÓSSEA
}

Presidente da banca: Prof. Dr. Lionel Fernel Gamarra Contreras

\author{
BANCA EXAMINADORA
}

Membros titulares:

Dra. Luciana Cavalheiro Marti

Dra. Jessica Ruivo Maximino

Profa. Dra. Érika Bevilaqua Rangel

Membros suplentes:

Profa. Dra. Patrícia Severino

Dr. Alessandro Rodrigo Belon

Aprovada em: 02/07/2021. 


\section{Dedicatória}

À minha mãe, Terezinha Anselmo de Figueiredo, que sempre me apoiou em todos os momentos, infelizmente ela não está mais aqui para ver a conclusão do trabalho, e embora não soubesse exatamente do que se trata um mestrado, tenho certeza que estaria orgulhosa deste momento. Também dedico a minha namorada Sandra Kuroiwa Iguma e meu pai Patrocínio Rosa de Oliveira que tem sido meus companheiros nessa nova etapa da vida. 


\section{Agradecimentos}

Ao Prof. Dr. Lionel Gamarra pela oportunidade de ser seu aluno, pelos ensinamentos transmitidos durante todo o processo de construção dessa dissertação e pela confiança no meu trabalho.

Ao Prof. Dr. Hélio Rodrigues da Silva por ter tido papel importante na minha formação como Biomédico e por ter me convidado para conhecer o grupo de nanobiotecnologia.

Ao Prof. Dr. Lucas Eduardo Botelho de Souza pela ajuda nos experimentos e por ter aceitado ser meu coorientador neste trabalho.

Aos colegas, Mariana Penteado Nucci e Javier Bustamente Mamani pelas contribuições fundamentais para a execução do trabalho.

Aos colegas de tantos experimentos em laboratório, Arielly da Hora Alves, Bruna Souto Marinho, Eduarda Figueiredo Ribeiro, Fernando Alvieri, Giselly Passos, Igor Salerno Filgueiras, João Victor Matias Ferreira, Paloma de Lima Espinha, Paulo Gabriel César Machado e Ricardo Silva dos Santos.

À equipe do Centro de Experimentação e Treinamento em Cirurgia (CETEC) pelo fornecimento dos animais e da infraestrutura necessária para que o trabalho pudesse ser realizado. Em especial a Camila Fernanda Hernandes e Lucas Renan Rodrigues da Silva pela amizade e ajuda em questões fundamentais.

Ao Dr. Luiz Vicente Rizzo e a toda a equipe do Instituto Israelita de Ensino e Pesquisa (IIEP), em especial Laudiceia Almeida e Jaciele Silva, por todo o auxílio prestado durante todo o processo do programa de Pós-Graduação Strictu Sensu da Faculdade Israelita de Ciências da Saúde Albert Einstein (FICSAE).

Aos Amigos da Oncologia e Hematologia Einstein (AMIGOH) pelo financiamento do projeto.

Ao Hospital Israelita Albert Einstein pelo apoio e pela bolsa de estudos cedida para realização do mestrado.

Ao Ministério da Ciência e Tecnologia e Inovações (MCTI) e ao Conselho Nacional de Desenvolvimento Científico e Tecnológico (CNPq) pela bolsa concedida via SisNano (442539/2019-3). 


\section{Sumário}

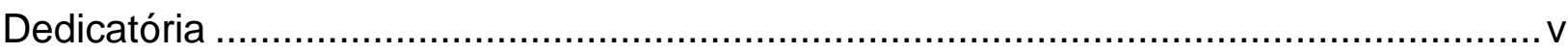

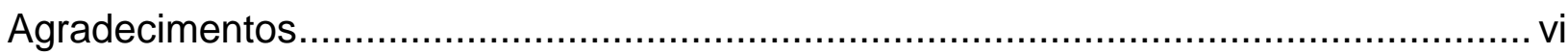

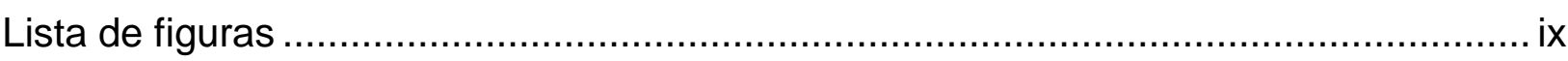

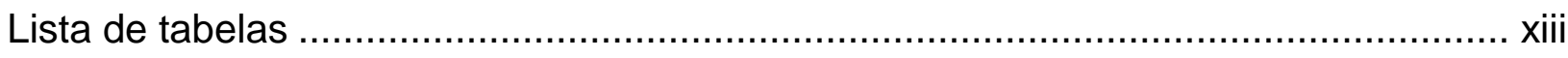

Lista de abreviaturas ...................................................................................

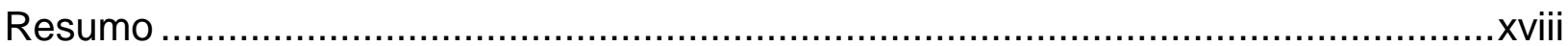

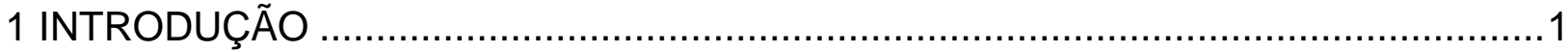

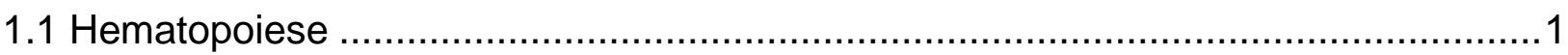

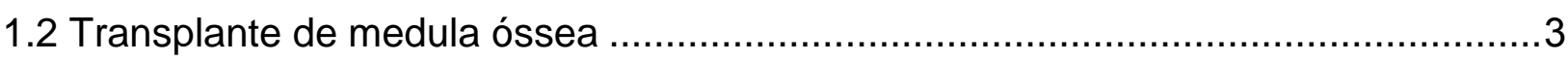

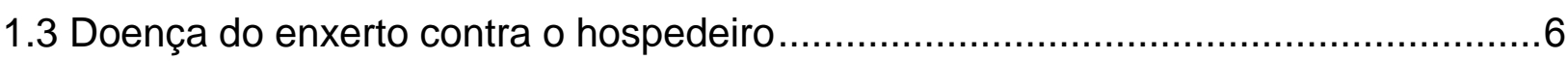

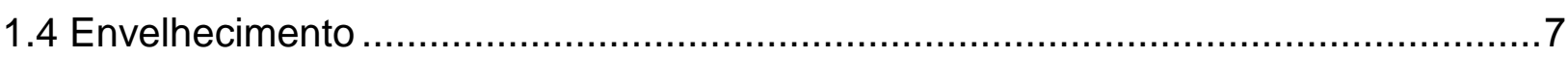

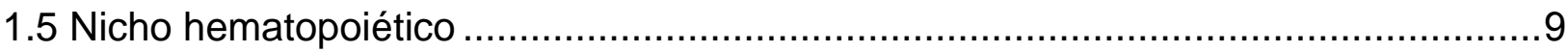

1.6 Homing das células-tronco hematopoiéticas para a medula óssea ......................11

1.7 Nanotecnologia aplicada ao rastreamento celular .......................................... 12

1.7.1 Nanopartículas superparamagnéticas de óxido de ferro ..............................14

1.8 Imagem molecular para o rastreamento de processos biológicos ........................ 15

1.8.1 Imagem por ressonância magnética.................................................. 18

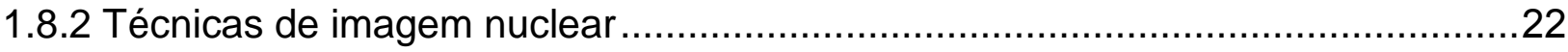

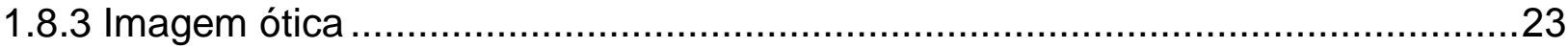

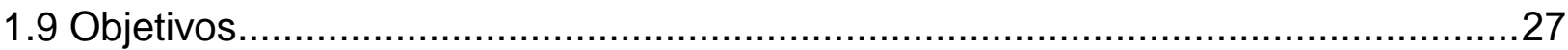

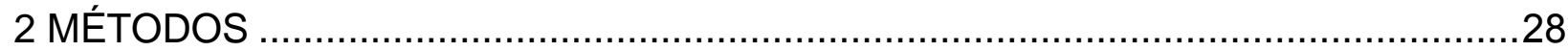

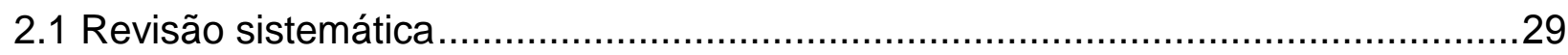

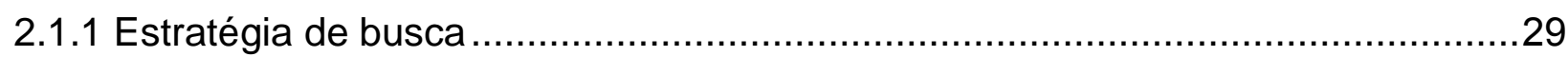

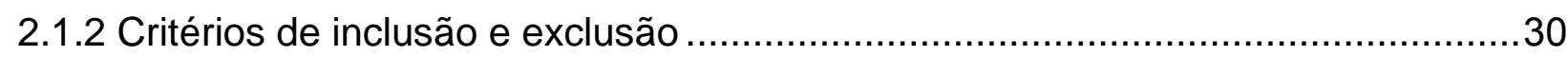

2.1.3 Extração e coleta de dados e avaliação de risco de viés .................................30

2.1.4 Análise de dados da revisão sistemática........................................................ 31

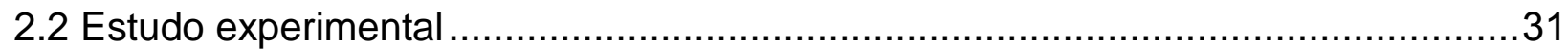

2.2.1 Avaliação físico-química das nanopartículas multimodais ................................31

2.2.1.1 Nanopartículas multimodais de oxido de ferro com dupla fluorescência ...........31

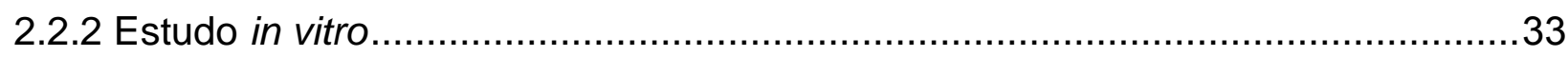

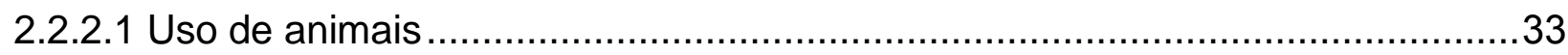




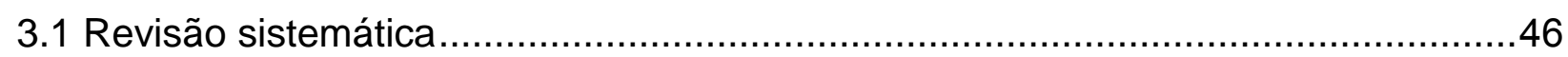

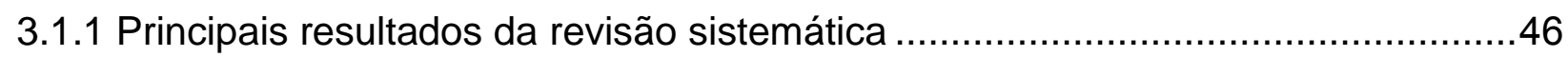

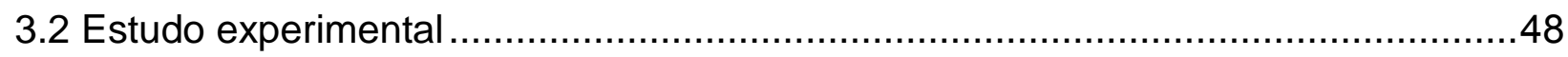

3.2.1 Avaliação físico-químicas das nanopartículas multimodais ................................48

3.2.1.1 Avaliação do tamanho hidrodinâmico e potencial zeta das nanopartículas

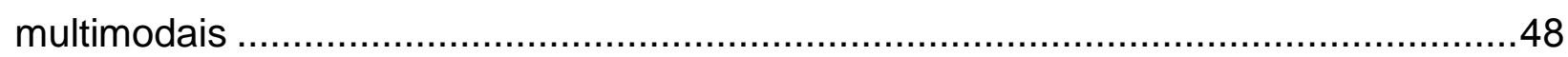

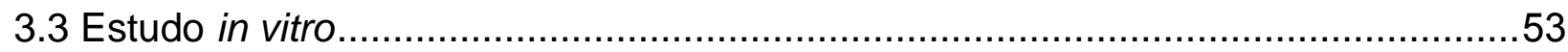

3.3.1 Caracterização de células lin- sca1+ c-kit+ a partir de células mononucleares da medula óssea

3.3.2 Avaliação da transdução das células mononucleares da medula óssea de camundongos jovens e idosos com vetor lentiviral por imagem de bioluminescência in vitro. .55

3.3.3 Avaliação da marcação das células mononucleares da medula óssea de camundongos jovens e idosos com nanopartículas multimodais .57

3.3.4 Avaliação da marcação das células mononucleares da medula óssea por imagem de fluorescência no infravermelho próximo e viabilidade após marcação por imagem de bioluminescência . .59

3.3.5 Avaliação da marcação das células mononucleares da medula óssea por imagem de ressonância magnética.

3.3.6 Quantificação do ferro internalizado nas células mononucleares da medula óssea de camundongos jovens e idosos .65

3.4 Estudo in vivo .74

3.4.1 Avaliação da curva de dose letal .74

3.4.2 Avaliação da migração das células mononucleares da medula óssea de camundongos jovens e idosos .75

3.4.3 Avaliação da reconstituição hematológica .83

3.4.4 Quantificação de células linhagem- Sca-1+ c-Kit+ na medula receptora. .85

4 DISCUSSÃO .86

5 CONCLUSÕES .93

6 REFERÊNCIAS .94

Abstract 


\section{Lista de figuras}

Figura 1. Representação diagramática da célula-tronco hematopoiética e das linhagens celulares que surgem a partir dela até as células maduras do tecido sanguíneo. 2 Figura 2. Desenvolvimento global do transplante de células-tronco hematopoiéticas de 1957-2012

Figura 3. Processo de encurtamento dos telômeros das células-tronco hematopoiéticas levando a imunosenescência e falha da medula óssea .8

Figura 4. Diferenças do enxerto entre animais jovens e idosos, em relação a proliferação e diferenciação das células após transplante

Figura 5. Localização dos nichos hematopoiéticos em cavidades ósseas trabeculares

Figura 6. Diferentes nanopartículas orgânicas e inorgânicas utilizadas para marcação celular 13

Figura 7. Representação de uma nanopartícula magnética de oxido de ferro (núcleo), que apresenta uma cobertura com caráter biocompativel, que pode ser funcionalizado à superfície para direcionar ao alvo específico além de ser utilizado como contraste pode ser utilizado para processos terapêuticos

Figura 8. Agentes de rastreamento utilizados pelas diferentes técnicas de imagem molecular..... 16

Figura 9. Processo de relaxação $\mathrm{T} 1$ e T2, em função das mudanças das magnetizações longitudinal e transversal a partir de um pulso de excitação de radiofrequência, onde inicialmente possui uma magnetização inicial, processo que acontece para a obtenção do sinal do sinal de ressonância magnética 19

Figura 10. Curvas de T2 mostrando a diferença entre as curvas na ausência e presença de nanopartículas magnéticas como contraste tanto para curtos e longos de tempo de eco, a partir de pulsos de excitação 20

Figura 11. Princípio das técnicas de tomografia por emissão de pósitrons e tomografia computadorizada por emissão de fóton único .23

Figura 12. Princípio das técnicas de imagem ótica

Figura 13. Reação química que ocorre na bioluminescência entre luciferase e luciferina para geração de luz. .25

Figura 14. Desenho experimental do estudo dividido em quatro etapas .28 
Figura 15. Coleta e isolamento de células mononucleares da medula óssea .36

Figura 16. Fluxograma baseado nas diretrizes do PRISMA para o processo de seleção de artigos para inclusão na revisão sistemática

Figura 17. Curva de polidispersão do diâmetro hidrodinâmico das nanopartículas multimodais suspensas na água

Figura 18. Curva de polidispersão do diâmetro hidrodinâmico das nanopartículas multimodais em várias condições. 49

Figura 19. Distribuição do potencial zeta das nanopartículas multimodais com núcleo de óxido de ferro cobertas com dextrana indicando o pico em 34,9mV .50

Figura 20. Análise da estabilidade das nanopartículas multimodais ao longo do tempo em água, meio de cultura e meio de cultura suplementado com soro fetal bovino .51

Figura 21. Espectro de excitação/emissão da nanopartícula multimodal evidenciando a dupla fluorescência da nanopartícula .52

Figura 22. Espectro 2D e 3D de excitação/emissão da nanopartícula multimodal ........53 Figura 23. Análise comparativa da população de células linhagem- Sca-1+ c-Kit+ de camundongos jovens e idosos com e sem a administração prévia de 5 -fluorouracil 4 dias antes da coleta das células

Figura 24. Análise de cinética da intensidade do sinal de bioluminescência de células mononucleares da medula óssea de camundongos jovens em função da concentração celular durante 297 minutos .55

Figura 25. Análise de cinética da intensidade do sinal de bioluminescência de células mononucleares da medula óssea de camundongos idosos em função da concentração celular durante 297 minutos .56

Figura 26. Curva de correlação da cinética de bioluminescência entre camundongos jovens e idosos após ajuste...

Figura 27. Microscopia de campo claro e fluorescência de células mononucleares da medula óssea marcadas com nanopartículas multimodais .58

Figura 28. Avaliação da intensidade de sinal de fluorescência no infravermelho próximo e viabilidade por bioluminescência de células mononucleares da medula óssea de animais jovens de idosos marcadas com nanopartículas multimodais em três concentrações diferentes

Figura 29. Intensidade de fluorescência no infravermelho próximo de células mononucleares da medula óssea de animais jovens de idosos marcadas com nanopartículas multimodais 
Figura 30. Representação gráfica da intensidade bioluminescência de células mononucleares da medula óssea de animais jovens de idosos marcadas com nanopartículas multimodais em diferentes concentrações

Figura 31. Avaliação da intensidade do sinal de ressonância magnética nas células mononucleares da medula óssea marcadas com nanopartículas multimodais.

Figura 32. Curva de calibração de fluorescência no infravermelho próximo a partir de concentrações conhecidas de nanopartículas multimodais. 66

Figura 33. Quantificação pela técnica de fluorescência no infravermelho próximo da internalização de nanopartículas multimodais/células mononucleares da medula óssea

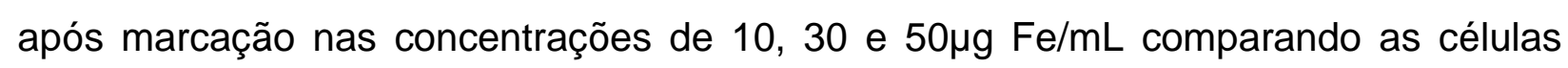
mononucleares da medula óssea de camundongos jovens e idosos.

Figura 34. Quantificação pela técnica de imagem de ressonância magnética da internalização de nanopartículas multimodais/células mononucleares da medula óssea após marcação na concentração de $50 \mu \mathrm{g} \mathrm{Fe} / \mathrm{mL}$ comparando as células mononucleares da medula óssea de camundongos jovens e idosos.

Figura 35. Curva de calibração de espectrometria de massa por plasma indutivamente acoplado a partir de concentrações conhecidas de nanopartículas multimodais ..

Figura 36. Quantificação pela técnica de espectrometria de massa por plasma indutivamente acoplado da internalização de nanopartículas multimodais/células mononucleares da medula óssea após marcação nas concentrações de 10, 30 e 50 $\mu \mathrm{g}$ $\mathrm{Fe} / \mathrm{mL}$ comparando as células mononucleares da medula óssea de camundongos jovens e idosos.

Figura 37. Análise de sobrevida realizada por 30 dias em animais que receberam irradiação de corpo inteiro

Figura 38. Rastreamento das células transplantadas de doadores jovens em receptores jovens por um período de 120 dias por imagem de bioluminescência ........76 Figura 39. Rastreamento das células transplantadas de doadores idosos em receptores jovens por um período de 120 dias por imagem de bioluminescência ........77 Figura 40. Intensidade de sinal de bioluminescência de animais que receberam células de doadores jovens e idosos ao longo de 120 dias. .78 Figura 41. Imagem de bioluminescência ex vivo dos principais órgãos de animais receptores de células de doadores jovens e idoso após 120 dias do transplante de medula óssea .79 
Figura 42. Imagem in vivo e ex vivo de fluorescência no infravermelho próximo 24 após o transplante de células provenientes de animais jovens e idosos .81 Figura 43. Análise histológica de tecidos de animais submetidos ao transplante de medula óssea cortados com $5 \mu \mathrm{m}$ e corados com azul da Prússia e nuclear fast red no aumento de 100x .82

Figura 44. Análise por hemograma da reconstituição hematopoiética dos animais receptores de células de doadores jovens e idosos por 120 dias .84 Figura 45. Análise por citometria de fluxo da população de células linhagem- Sca-1+ cKit+ presente na medula óssea receptora de células de animais jovens e idosos após 120 dias da realização do transplante de medula óssea. .85 


\section{Lista de tabelas}

Tabela 1. Principais características das técnicas de imagem molecular..... 21

Tabela 2. Amostras para a avaliação da influência do meio sobre o tamanho hidrodinâmico 33

Tabela 3. Processo de fixação e inclusão dos tecidos 44

Tabela 4. Valores das intensidades de fluorescência no infravermelho próximo das amostras de células mononucleares da medula óssea de animais jovens de idosos marcadas com nanopartículas multimodais.

Tabela 5. ANOVA da intensidade de fluorescência no infravermelho próximo das células mononucleares da medula óssea de animais jovens de idosos marcadas com nanopartículas multimodais

Tabela 6. Teste de post hoc da intensidade de fluorescência no infravermelho próximo das células mononucleares da medula óssea de animais jovens de idosos marcadas com nanopartículas multimodais

Tabela 7. Valores das intensidades de bioluminescência das amostras de células mononucleares da medula óssea de animais jovens e idosos marcadas com nanopartículas multimodais

Tabela 8. ANOVA da intensidade de bioluminescência das células mononucleares da medula óssea marcadas com nanopartículas multimodais .63

Tabela 9. Teste de post hoc da intensidade de bioluminescência das células mononucleares da medula óssea marcadas com nanopartículas multimodais 63

Tabela 10. Valores de relaxação spin-spin das amostras de células mononucleares da medula óssea de animais jovens e idosos marcadas com nanopartículas multimodais obtidas pela imagem de ressonância magnética.

Tabela 11. ANOVA dos valores de relaxação spin-spin das amostras de imagem de ressonância magnética das células mononucleares da medula óssea marcadas com nanopartículas multimodais

Tabela 12. Teste de post hoc dos valores de $T 2$ de imagem de ressonância magnética das amostras de células mononucleares da medula óssea de animais jovens e idosos marcadas com nanopartículas multimodais.

Tabela 13. Valores das da quantificação do ferro internalizado nas CMN-MO por NIRF de animais jovens e idosos marcadas com NPMM 
Tabela 14. ANOVA da quantificação do ferro internalizado nas CMN-MO por NIRF ....68 Tabela 15. Teste de post hoc da quantificação do ferro internalizado nas Células mononucleares da medula óssea por fluorescência no infravermelho próximo .68

Tabela 16. Valores da quantificação do ferro internalizado nas células mononucleares da medula óssea de animais jovens e idosos marcadas com nanopartículas multimodais por imagem de ressonância magnética.

Tabela 17. Teste $t$ da quantificação do ferro internalizado nas células mononucleares da medula óssea por imagem de ressonância magnética de animais jovens e idosos marcadas com nanopartículas multimodais.

Tabela 18. Valores das da quantificação do ferro internalizado nas células mononucleares da medula óssea por espectrometria de massa por plasma indutivamente acoplado de animais jovens e idosos marcadas com nanopartículas multimodais .72

Tabela 19. ANOVA da quantificação do ferro internalizado nas células mononucleares da medula óssea por espectrometria de massa por plasma indutivamente acoplado...72 Tabela 20. Teste de post hoc da quantificação do ferro internalizado nas células mononucleares da medula óssea por espectrometria de massa por plasma indutivamente acoplado

Tabela 21. Comparação da massa de ferro e número de nanopartículas multimodais internalizadas por células mononucleares da medula óssea mediante as técnicas de fluorescência no infravermelho próximo, espectrometria de massa por plasma indutivamente acoplado e imagem de ressonância magnética, nas concentrações de 10,30 e $50 \mu \mathrm{g}$ de nanopartículas multimodais $/ \mathrm{mL}$

Tabela 22. Valores de intensidade de sinal de bioluminescência de animais que receberam células de doadores jovens e idosos ao longo de 120 dias .78 


\section{Lista de abreviaturas}

7-AAD 7-amino-actinomicina D

AAALAC Association for Assessment and Accreditation of Laboratory Animal Care International

BLM Bioluminescência

CAA Células apresentadoras de antígeno

CEM Células estromais mesenquimais

CETEC Centro de Experimentação e Treinamento em Cirurgia

CEUA Comissão de Ética na Utilização de Animais

CMN-MO Células mononucleares da medula óssea

CPS Contas por segundo

CRA Células reticulares abundantes em CXCL12

CTH Célula-tronco hematopoiética

CTH-CP Células-tronco hematopoiéticas de curto prazo

CTH-LP Células-tronco hematopoiéticas de longo prazo

CXCL12 Quimiocina CXC-12

DAPI Diamidino-2-fenilindol

DECH Doença do enxerto contra o hospedeiro

DNA Ácido desoxirribonucleico (Deoxyribonucleic acid)

EDTA Ácido etilendinetrilo tetra-acético-sal dissódico dihidratado

FL Fluorescência

FLuc Luciferase de vagalume (Firefly luciferase)

FMO Fluorescência menos um (Fluorescence Minus One)

FOV Campo de visão (Field of view)

GFP Proteína verde fluorescente (Green fluorescent protein)

GLuc Gaussia luciferase

HIAE Hospital Israelita Albert Einstein

HLA Antígeno leucocitário humano (Human leukocyte antigen)

ICI Irradiação de corpo inteiro

ICP-MS Espectrometria de massa por plasma indutivamente acoplado (Inductively Coupled Plasma Mass Spectrometry)

IIEP Instituto Israelita de Ensino e Pesquisa 


$\begin{array}{ll}\text { IL-3 } & \text { Interleucina } 3 \\ \text { IL-6 } & \text { Interleucina } 6 \\ \text { IRM } & \text { Imagem de ressonância magnética } \\ \text { LKS } & \text { Células linhagem- Sca-1+ c-Kit+ } \\ \text { MHC } & \text { Complexo principal de histocompatibilidade (Major histocompatibility } \\ & \text { complex) } \\ \text { MO } & \text { Medula óssea } \\ \text { MOI } & \text { Multiplicidade de infecção } \\ \text { MT } & \text { Magnetização transversal } \\ \text { NIRF } & \text { Fluorescência no infravermelho próximo (Near infrared fluorescence) } \\ \text { NPMM } & \text { Nanopartículas multimodais } \\ \text { NSOF } & \text { Nanopartículas superparamagnéticas de óxido de ferro } \\ \text { PBS } & \text { Tampão fosfato-salino (Phosphate buffered saline) } \\ \text { PCR } & \text { Reação em cadeia da polimerase (Polymerase chain reaction) } \\ \text { PEG } & \text { Polietilenoglicol } \\ \text { PEI } & \text { Politilenimina } \\ \text { PET } & \text { Tomografia por emissão de pósitrons (Positron emission tomography) } \\ \text { PLL } & \text { Poli-L-lisina } \\ \text { PRISMA } & \text { Principais itens para relatar revisões sistemáticas e meta-análises } \\ & \text { (Preferred Reporting ltems for Systematic Reviews and Meta-Analyses) } \\ \text { PVA } & \text { Álcool polivinílico (Polyvinyl alcohol) } \\ \text { PVP } & \text { Polivinilpirrolidona } \\ \text { RLuc } & \text { Renilla luciferase } \\ \text { ROI } & \text { Região de interesse } \\ \text { SCF } & \text { Fator de célula-tronco (Stem cell fator) } \\ \text { SCUP } & \text { Sangue de cordão umbilical e placentário } \\ \text { SFB } & \text { Soro fetal bovino } \\ \text { SFEM } & \text { StemSpan Serum-Free Expansion Medium } \\ \text { SPECT } & \text { Tomografia computadorizada por emissão de fóton único (Single-photon } \\ & \text { emission computed tomography) } \\ \text { TCMM } & \text { Sangue periférico mobilizado } \\ \text { T1 } & \text { Relaxação spin-rede } \\ & \text { Relaxação spin-spin } \\ \text { Transplante de células-tronco hematopoiéticas } \\ \text { TH }\end{array}$


TMO Transplante de medula óssea

WBMT Worldwide Network for Bone Marrow Transplantation 


\section{Resumo}

Introdução: $O$ transplante de medula óssea é um procedimento terapêutico utilizado como tratamento para diversas patologias hematológicas, baseado na capacidade da célula-tronco hematopoiética de se autorrenovar e se diferenciar nas diversas linhagens do tecido hematopoiético. O envelhecimento da célula-tronco hematopoiética está ligado à capacidade reduzida de migrar, enxertar e se diferenciar em linhagens hematopoiéticas, outra dificuldade é a falta de dados consistentes em experimentos in vivo que permitam gerar dados sobre a cinética do enxerto e migração das célulastronco hematopoiéticas de forma não invasiva que possam melhorar o processo de transplante e enxerto. A marcação das células com nanopartículas ou transduzidas com luciferase aliado às técnicas de imagem molecular podem contribuir para um melhor entendimento sobre sua dinâmica após realização do transplante. Objetivos: Avaliar o homing de células-tronco hematopoiéticas de camundongos jovens e idosos, marcadas com nanopartículas multimodais e modificadas para expressão de luciferase, por técnicas de imagem molecular em modelo de transplante de medula óssea. Métodos: Foi realizada uma revisão sistemática da literatura para buscar as melhores estratégias para se realizar o rastreamento não invasivo de células-tronco hematopoiéticas em modelo de transplante de medula óssea. Em seguida a caracterização fisíco-química das nanopartículas multimodais (propriedades magnéticas e fluorescentes) quanto ao seu tamanho hidrodinâmico, estabilidade, potencial zeta e propriedades óticas. Após a caracterização marcamos as células mononucleares da medula óssea de camundongos jovens e idosos com nanopartículas e transduzimos para expressão de luciferase para realização análises de viabilidade, sensibilidade e quantificação da internalização por técnicas de como imagem de bioluminescência, ressonância magnética, fluorescência próxima ao infravermelho e espectrometria de massa com plasma indutivamente acoplado. Uma vez marcadas as células foram transplantadas e avaliadas por técnicas de imagem molecular, histológicas e hematológicas. Resultados: A revisão sistemática indicou que as técnicas de imagem de bioluminescência, fluorescência, ressonância magnética, tomografia por emissão de pósitrons e tomografia por emissão de fóton único são as mais utilizadas para o rastreamento não invasivo de células tronco hematopoiéticas. $A$ caracterização evidenciou um pontecial zeta positivo $(34,9 \mathrm{mV})$ que favorece a 
internalização das nanopartículas multimodais nas células, além disso, as nanopartículas se mostraram estáveis no meio de cultura utilizado para marcação, evitando a formação de aglomerados que podem prejudicar sua internalização. Também pode ser observado que após marcação na maior concentração de nanopartículas que as células se mantiveram 95\% viáveis, além de possibilitar a quantificação de nanopartículas internalizadas nas células por diversas técnicas, sendo que só houve diferença significativa entre jovens e idosos na quantificação de ferro por espectrometria de massa na mesma concentração, entretanto, obtivemos uma diferença significativa entre todas as diferentes concentrações de marcação (10, 30 e $50 \mu \mathrm{g} \mathrm{Fe} / \mathrm{mL}$ ), encontrando uma internalização por todas as técnicas na ordem de picogramas de ferro por célula ou em número de nanopartículas por célula na ordem de $10^{4}$. No estudo in vivo observamos por imagem de fluorescência no infravermelho próximo as células marcadas com nanopartículas 24 horas após o transplante em todos os órgãos analisados, com destaque para os órgãos hematopoiéticos (baço e medula óssea), resultado que foi corroborado pelas de bioluminescência ex vivo e análise histológica. A avaliação por imagem de bioluminescência permitiu acompanhar o enxerto do $11^{\circ}$ dia até o $120^{\circ}$, mas, sem diferenças entre o enxerto jovem e idoso, essa diferença pode ser observada apenas na análise hematológica, que demonstrou um enxerto enviesado para a linhagem mieloide. Conclusões: A revisão sistemática possibilitou direcionar nosso estudo para uma melhor abordagem de todos os aspectos referentes ao modelo de rastreamento não invasivo após transplante de medula óssea, principalmente nos tempos e parâmetros de avaliação. As nanopartículas utilizadas não alteraram a viabilidade celular de maneira expressiva e possibilitaram a quantificação por várias técnicas. A combinação de imagem de bioluminescência e fluorescência propiciou um acompanhamento das células em todas as etapas do transplante, mas sem evidenciar diferenças no enxerto jovem e idoso, sendo necessário complementar as técnicas de imagem molecular, com outras técnicas que permitam trazer dados sobre a eficácia do enxerto.

Descritores: Nanopartículas; Imagem de bioluminescência [não DeCS]; Imagem de fluorescência [não DeCS]; Imageamento por ressonância magnética; Células-tronco hematopoéticas; Transplante de medula óssea; Imagem molecular 


\section{INTRODUÇÃO}

O presente capítulo apresenta as bases teóricas para o entendimento do trabalho, primeiramente descrevendo o transplante de medula óssea (TMO) e suas aplicações, abordando as propriedades e características da célula-tronco hematopoiética (CTH) que possibilita a realização do TMO pela sua capacidade de autorrenovação e diferenciação, também explora a influência do envelhecimento nas CTH que prejudica sua migração e enxerto. Além disso, evidência a dificuldade para rastrear as $\mathrm{CTH}$ in vivo após o TMO e como técnicas de imagem molecular que possibilitam imagem não invasiva como: imagem de ressonância magnética (IRM), tomografia por emissão de pósitrons (PET - positron emission tomography), tomografia computadorizada por emissão de fóton único (SPECT - single-photon emission computed tomography), bioluminescência (BLM) e fluorescência (FL) possibilitam avaliar a migração das células em busca de um melhor entendimento sobre a dinâmica in vivo das CTH após o transplante, sobretudo com o auxílio de recursos nanotecnológicos para a criação de sondas multifuncionais que potencializam o rastreamento das células.

\subsection{Hematopoiese}

A hematopoiese, do grego haima (sangue) mais poiese (produção), é o processo no qual uma $\mathrm{CTH}$, consegue dar origem as diversas células do tecido hematopoiético (leucócitos, neutrófilos, eosinófilos, basófilos, linfócitos, monócitos, eritrócitos e plaquetas), pela sua capacidade de autorrenovação e diferenciação em linhagens comprometidas. ${ }^{(1)}$ Existem dois tipos principais de células progenitoras hematopoiéticas comprometidas com suas linhagens específicas, as células progenitoras mieloides e as células progenitoras linfoides, as progenitoras mieloides dão origem as células da linhagem granulocítica, monocítica, eritróide e megacariocítica, as progenitoras linfoides dão origem somente as células da linhagem linfocítica como pode ser observado na figura $1 .^{(2)}$ 


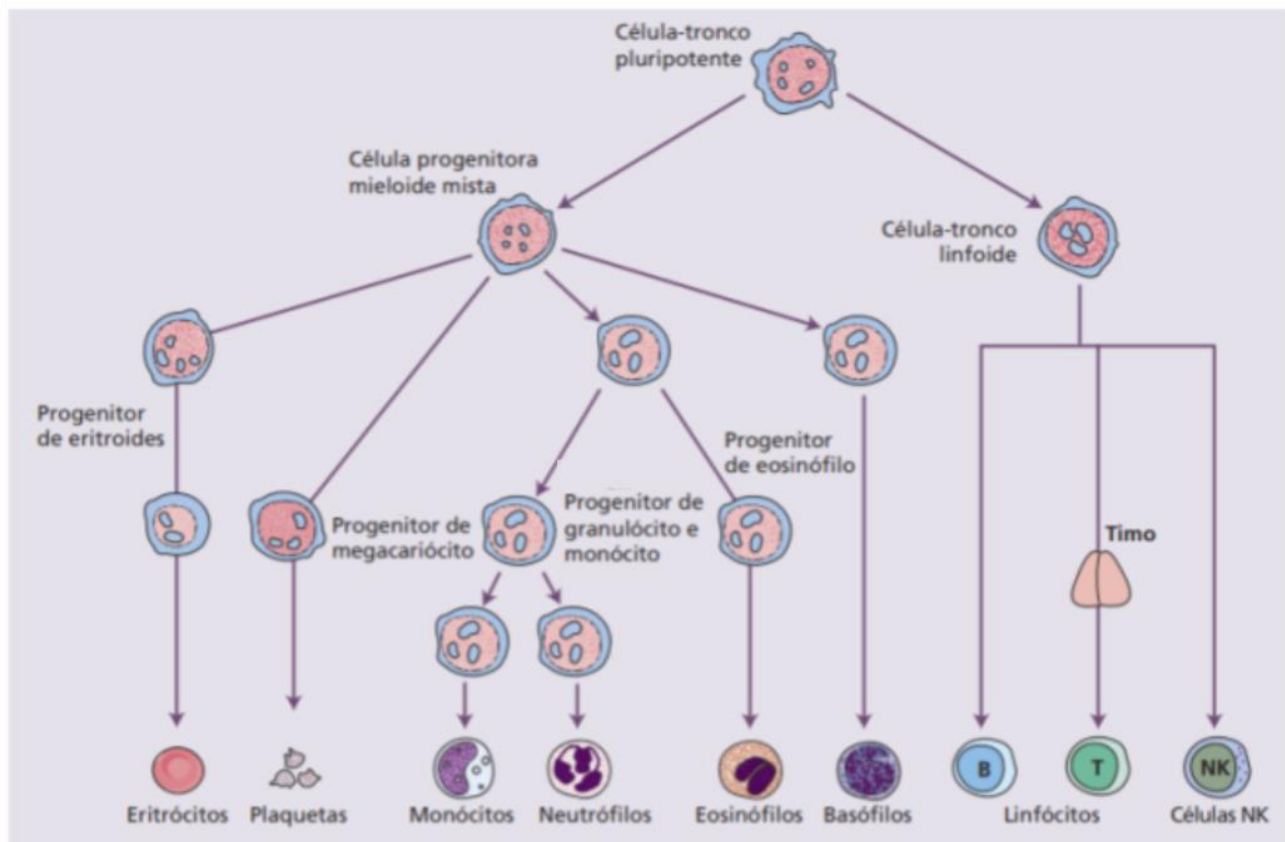

NK: natural killer.

Fonte: Adaptado de Hoffbrand AV, Moss PA, Pettit JE. Fundamentos em hematologia. Porto Alegre: Artmed; 2008. Figura 1.2 Diagrama mostrando a célulatronco multipotente da medula óssea e as linhagens celulares que dela se originam; p. $12 .^{(3)}$

Figura 1. Representação diagramática da célula-tronco hematopoiética e das linhagens celulares que surgem a partir dela até as células maduras do tecido sanguíneo

Em mamíferos a hematopoiese tem início no saco vitelino. Essa fase é conhecida como onda primitiva e é transitória, nela ocorre apenas a formação de progenitores eritroides, que vão fornecer oxigênio ao embrião. Esses progenitores eritróides são unipotentes e não são capazes de se autorrenovar. ${ }^{(4,5)}$

A onda definitiva da hematopoiese tem início quando fígado e baço começam a produzir as células sanguíneas. Essa fase se origina a partir de uma população de células encontradas na região aorta-gonadal-mesonéfrica,${ }^{(6)}$ que migram para o fígado fetal, transformando o fígado no principal órgão hematopoiético desse período. No fim da vida fetal a medula óssea (MO) aumenta a produção de células sanguíneas, após o período natal o fígado para a produção de células hematopoiéticas e a MO passa ser o principal órgão hematopoiético. ${ }^{(2)}$

As CTH representam uma pequena população de células contidas na MO do indivíduo adulto, estima-se que em cada $1 \times 10^{4}$ células presentes na $\mathrm{MO}$, somente uma seja $\mathrm{CTH}^{(7)}$ e por não possuírem um fenótipo exato conhecido, o principal marcador das CTH segue sendo o CD34+ que está presente em cerca de 2 a $5 \%$ das células mononucleadas da MO, sendo as células Lin- CD34+ CD38- CD90+ 
CD45RA- a população celular mais primitiva encontrada em humanos, já em camundongos a melhor representação das CTH está em Lin- c-Kit+ Sca1+ Flk2- CD34Slamf1+. ${ }^{(8,9)}$

As CTH são divididas em duas subpopulações de acordo com sua capacidade de se autorrenovar, células-tronco hematopoiéticas de longo prazo (CTHLP) e células-tronco hematopoiéticas de curto prazo (CTH-CP), as CTH-LP são responsáveis pela manutenção da população indiferenciada de $\mathrm{CTH}$, já as CTH-CP são células comprometidas que tem origem em divisões assimétricas das CTH-LP, quando uma CTH-LP se duplica preserva seu clone para manutenção da hematopoiese, enquanto a CTH-CP formada se compromete com uma linhagem hematopoiética. ${ }^{(9)}$

A MO vermelha encontrada no interior da grande maioria dos ossos é a principal fonte das $\mathrm{CTH}$, ela está presente principalmente nos indivíduos jovens e, com o passar do tempo essa MO vai sendo substituída pela $\mathrm{MO}$ amarela que é rica em tecido adiposo e possui atividade hematopoiética insignificante, exceto nas regiões proximais dos ossos longos. ${ }^{(10)}$

Além do envelhecimento que prejudica a reposição adequada das $\mathrm{CTH}$, outros fatores como algumas doenças hematológicas podem levar ao comprometimento da produção de células sanguíneas, produção insuficiente de células, produção descontrolada de células imaturas ou alterações genéticas que prejudiquem a função das células sanguíneas, entre outras. Nesses casos há a necessidade da realização de um TMO para que ocorra o reestabelecimento da hematopoiese. ${ }^{(11)}$

\subsection{Transplante de medula óssea}

O TMO, também conhecido como transplante de células-tronco hematopoiéticas (TCTH), é um procedimento terapêutico realizado pela infusão de $\mathrm{CTH}$ de pacientes saudáveis em pacientes com medula defeituosa, ${ }^{(12)}$ essas células podem ser retiradas não só da MO, como também do sangue periférico mobilizado (SPM), ou do sangue de cordão umbilical e placentário (SCUP), tendo como finalidade reestabelecer a função da medula. ${ }^{(11,13,14)}$

De acordo com o relatório da Worldwide Network for Bone Marrow Transplantation (WBMT), até o final de 2012, mais de um milhão de pacientes haviam 
sido submetidos ao TCTH (Figura 2). A grande maioria dos procedimentos de TCTH foi usada para tratar distúrbios malignos (87\%), sendo a maioria deles leucemias (72\%), seguidos por distúrbios linfoproliferativos $(14,7 \%)$ e tumores sólidos $(0,6 \%) .{ }^{(15)}$ O TCTH também é utilizado como tratamento para várias doenças genéticas, como imunodeficiência combinada grave, síndrome de Wiskott-Aldrich, talassemia, anemia falciforme, entre outras. ${ }^{(12)}$
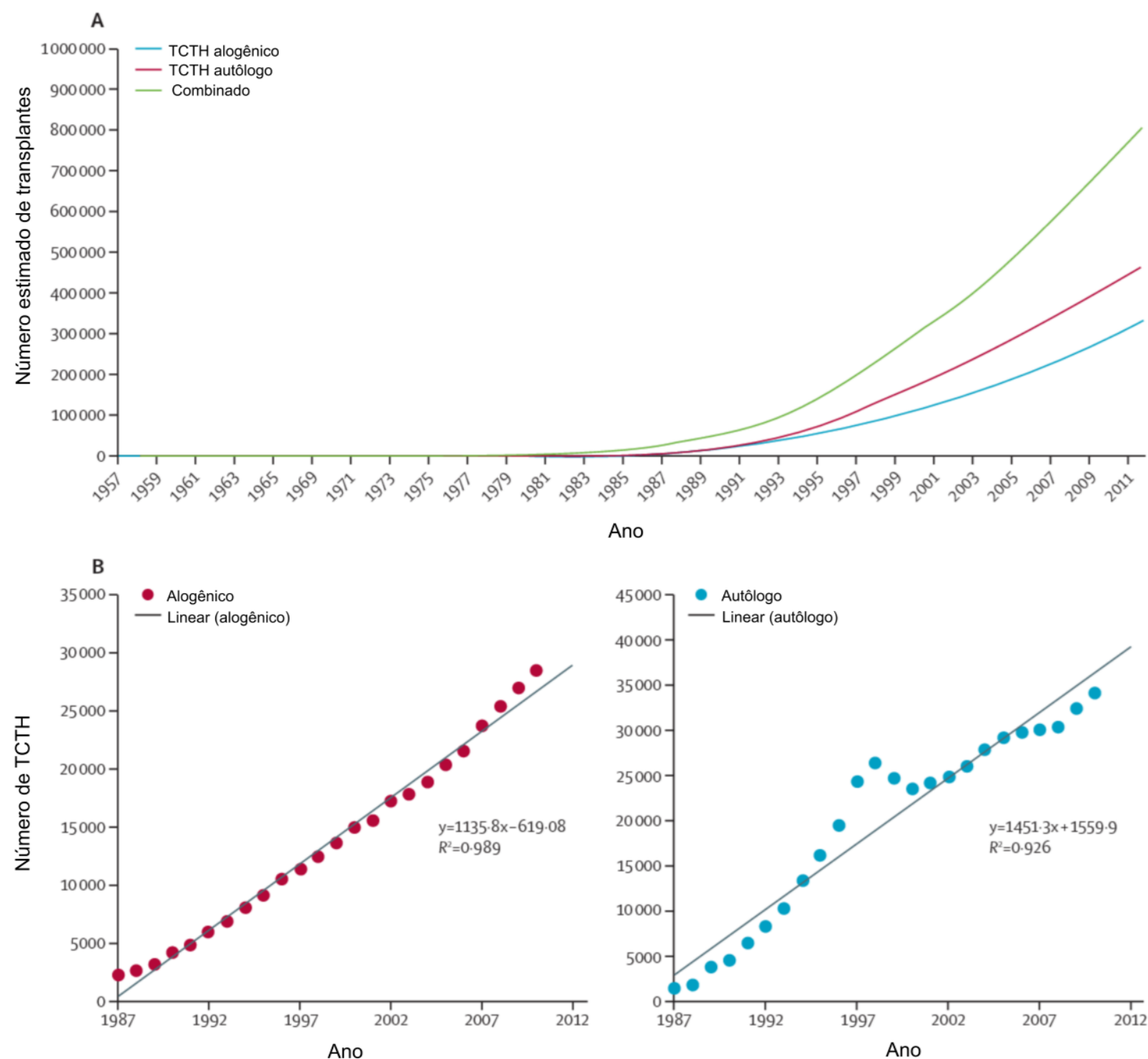

A: Crescimento do número de transplante de células-tronco hematopoiéticas alongênicos, autólogos e o total combinado realizados até o ano de 2012 no mundo. B: Crescimento linear do número de transplante de células-tronco hematopoiéticas alogênicos e autólogos realizados até o ano de 2012 no mundo. TCTH: transplante de células-tronco hematopoiéticas.

Fonte: Traduzido e adaptado de Gratwohl A, Pasquini MC, Aljurf M, Atsuta Y, Baldomero H, Foeken L, et al.; Worldwide Network for Blood and Marrow Transplantation (WBMT). One million haemopoietic stemcell transplants: a retrospective observational study. Lancet Haematol. 2015;2(3):e91-100. Figure 1: Global development of HSCT, 1957-2012. p. 3. ${ }^{(15)}$

Figura 2. Desenvolvimento global do transplante de células-tronco hematopoiéticas de 1957-2012 
O TCTH é dividido em modalidades quanto ao tipo de doador, o autólogo, ocorre quando as células transplantadas são retiradas do próprio paciente, o alogênico, quando as células vêm de um doador aparentado ou não aparentado, já a modalidade singênica, ocorre quando o doador é irmão gêmeo univitelino. ${ }^{(11,16)}$ Existe também a modalidade xenogênica de TCTH, quando as células transplantadas são de um doador de outra espécie, sendo restrita a estudos pré-clínicos. ${ }^{(17)}$

A disseminação do TCTH como modalidade terapêutica está intimamente ligada à identificação e tipificação do principal complexo de antígeno leucocitário humano (HLA - human leukocyte antigen) que teve início nos anos 60. Como consequência dessas descobertas, o TCTH alogênico entre indivíduos com HLA compatível tornou-se viável. Quase metade dos procedimentos de TCTH são alogênicos, de acordo com a mais recente pesquisa global. ${ }^{(15)}$

Para a realização do TCTH é necessário que doador e receptor sejam compatíveis, sendo a condição mais favorável quando doador e receptor são irmãos gêmeos idênticos, porém a parcela de pacientes que possui irmão gêmeo idêntico é mínima, há também a chance que um parente próximo seja compatível, mas infelizmente mais de $60 \%$ dos pacientes não possuem um doador aparentado compatível. ${ }^{(18)}$

O problema da compatibilidade só será resolvido quando as barreiras do HLA forem superadas, nesse sentido a realização de TCTH haploidênticos surge como uma opção. Nessa forma de TCTH, as células do doador têm o HLA parcialmente semelhante as do receptor (superior a 50\%), e para sua realização é necessário que o paciente seja submetido a um regime de imunossupressão, geralmente utilizando uma das seguintes estratégias: depleção dos linfócitos $T$ in vitro antes do transplante ou uso de ciclofosfamida que inibe as células que estão se multiplicando em grande quantidade como linfócitos $T$ aloreativos. Outra estratégia é o uso de células-tronco do SCUP, essas células necessitam de uma combinação menor de HLA, além da ausência de linfócitos T maduros. ${ }^{(19-22)}$

A incompatibilidade do HLA também é a principal dificuldade presente após o TCTH alogênico, devido a isto os pacientes que realizam o TCTH são submetidos a regimes de imunossupressão, estas drogas imunossupressoras têm como finalidade modular a resposta imune, inibindo a ação das células transplantadas contra o receptor, para evitar a doença do enxerto contra o hospedeiro (DECH). ${ }^{(23)}$ Já o principal risco do transplante autólogo é a toxicidade de curto e longo prazos, por causa 
do condicionamento pré-transplante decorrente do uso de agentes quimioterápicos combinados ou não com irradiação de corpo inteiro $(\mathrm{ICl})$, que podem levar a danos nos órgãos, infecções e sangramentos associados à aplasia da MO. ${ }^{(24)}$

\subsection{Doença do enxerto contra o hospedeiro}

A DECH é uma complicação comum do TMO alogênico, no qual as células $T$ aloreativas do doador atacam os tecidos do receptor. ${ }^{(25)} \mathrm{A} D E C H$ é a principal barreira imune à eficácia do TMO alogênico e é a segunda causa de morte nos pacientes submetidos a esse procedimento, ficando atrás apenas da mortalidade causada pela doença primária. ${ }^{(26)}$

A DECH foi descrita pela primeira vez nos anos 60 , em experimentos com camundongos submetidos ao modelo de TMO com condicionamento por $\mathrm{ICl}$, esses camundongos tiveram células transplantadas a partir de animais isogênicos com complexo principal de histocompatibilidade (MHC - major histocompatibility complex) semelhante, também foram transplantadas células de animais não isogênicos, com MHC diferente, os animais que receberam células de camundongos não isogênicos vieram a desenvolver uma reação imune caracterizada por erupção cutânea e diarreia que foi chamada primeiramente de "doença de Runt" e posteriormente como $\mathrm{DECH} .{ }^{(27)}$

Outro estudo realizado em 1966 definiu os requisitos necessários para o desenvolvimento da DECH:

1ํ - o enxerto deve conter células imunologicamente competentes;

$2^{\circ}$ - o hospedeiro deve possuir aloantígenos que faltam no doador, para que o hospedeiro pareça estranho ao enxerto;

$3^{\text {o }}$ - o sistema imune do hospedeiro deve ser incapaz de gerar uma reação imunológica eficaz contra o enxerto, pelo menos por tempo suficiente para que ocorra a resposta imune. ${ }^{(28)}$

Anteriormente, a DECH era dividida temporalmente, em forma aguda e crônica, a forma aguda ocorria nos primeiros 100 dias após o transplante e era caracterizada por danos a pele, fígado e trato gastrointestinal, já a forma crônica ocorria após os primeiros 100 dias do transplante, possuindo manifestações mais 
diversas, podendo se assemelhar a várias síndromes, doenças de pele semelhantes, bem como, comprometimento das glândulas salivares e lacrimais. ${ }^{(29,30)}$

A forma aguda foi dividida em duas subcategorias, conforme as manifestações clínicas do paciente: clássica e tardia. A forma aguda clássica apresenta eritema, lesões máculo-papulosas, náusea, vômitos, anorexia, diarreia, íleo paralítico ou doença hepática colestática, e ocorre nos 100 primeiros dias após o TCTH, sem apresentar sinais da forma crônica. Já a forma aguda tardia, é semelhante à forma clássica, sem sinais da forma crônica e ocorre 100 dias após o TCTH. A forma crônica também foi dividida em duas subcategorias: clássica e síndrome de sobreposição, onde a forma crônica clássica não possui características da forma aguda e pode ocorrer a qualquer momento após o TCTH, já na síndrome de sobreposição as formas aguda e crônica se manifestam em conjunto e pode ocorrer a qualquer momento após o TCTH. ${ }^{(31,32)}$

\subsection{Envelhecimento}

Além das doenças hematológicas outro fator que leva a um prejuízo na hematopoiese é o envelhecimento das $\mathrm{CTH}$. O envelhecimento é um processo biológico que tem como características o declínio funcional de tecidos e órgãos; degeneração estrutural; capacidade de se adaptar e resistência reduzidas, o que acaba contribuindo para o aumento da morbimortalidade causada por múltiplas doenças crônicas. ${ }^{(33)}$ A principal causa de envelhecimento nas células está relacionada ao acúmulo de danos no ácido desoxirribonucleico (DNA - deoxyribonucleic acid), causando nas células-tronco alterações que modificam seu ciclo celular, levando a perda gradual da capacidade de se autorrenovar, o que ocasiona o envelhecimento do sistema em que elas atuam. ${ }^{(34)}$

A capacidade de proliferação das células está associada à manutenção da extensão dos seus cromossomos. Um dos principais causadores de danos ao DNA é a deterioração dos telômeros, estruturas de DNA não codificantes (TTAGGG) localizadas nas extremidades da dupla fita de DNA, sua principal função é proteger a informação genética contida nos cromossomos, que podem ser perdidas pela degradação que ocorre a cada divisão da célula. $O$ encurtamento dos telômeros pode causar instabilidade cromossômica, disfunção celular, limitação de proliferação e 
apoptose, estando associado ao processo de imunossenescência (Figura 3), desta forma a manutenção dos telômeros está relacionada ao potencial proliferativo das células. ${ }^{(35)}$

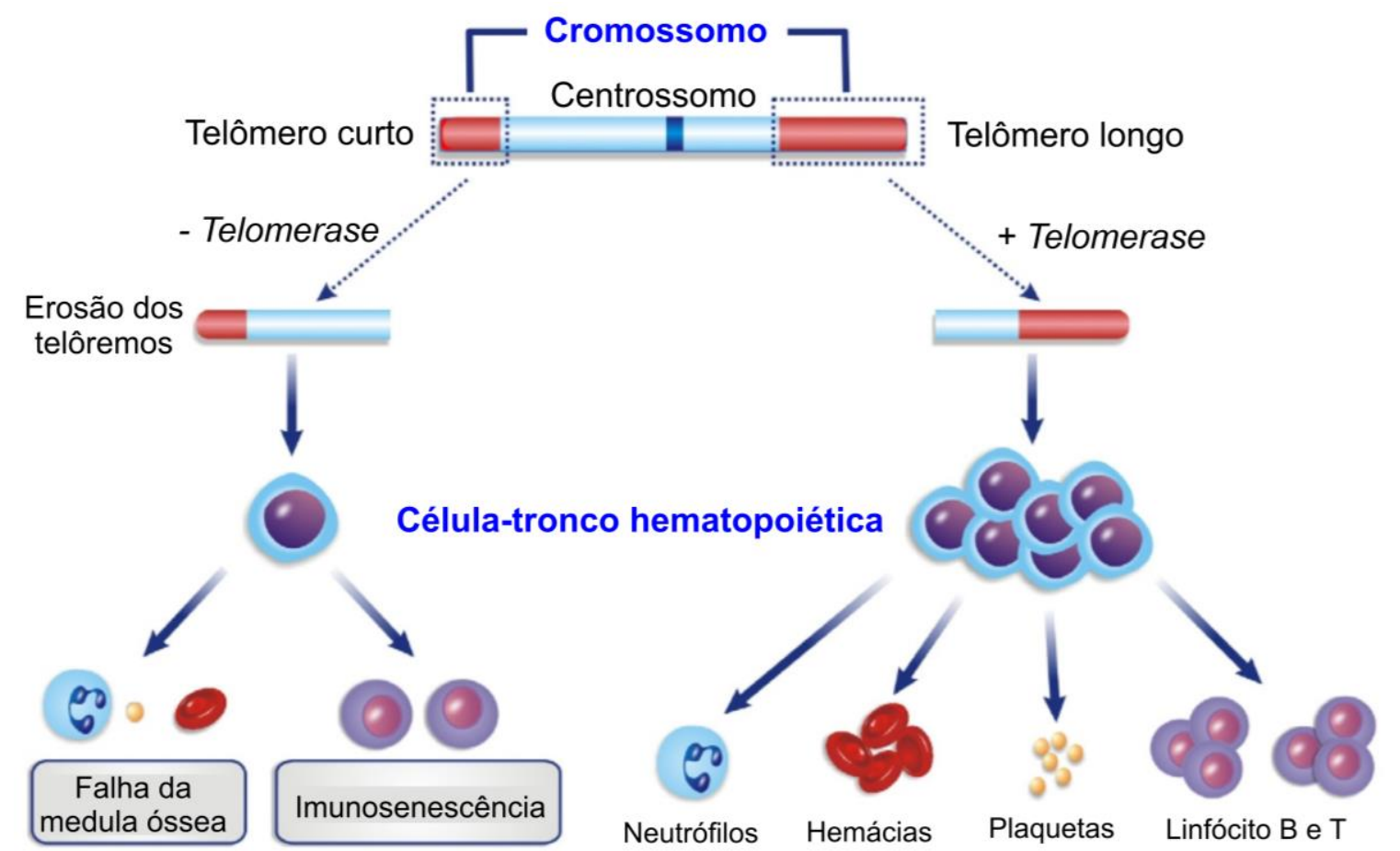

Fonte: Traduzido e adaptado de Paiva RM, Calado RT. Telomere dysfunction and hematologic disorders. Prog Mol Biol Transl Sci. 2014;125:133-57. Figure 6.1 Short telomeres engage hematopoietic stem cells into senescense and apoptosis, impairingthe appropriate production of peripheral blood cells. p. 134. ${ }^{(36)}$

Figura 3. Processo de encurtamento dos telômeros das células-tronco hematopoiéticas levando a imunosenescência e falha da medula óssea

Outros fatores que também influenciam no processo de envelhecimento das CTH são a polaridade (distribuição assimétrica de proteínas), autofagia prejudicada, atividade mitocondrial (acúmulo mitocondrial que leva a estresse metabólico) e reprogramação epigenética. ${ }^{(34)}$

Alguns trabalhos demonstraram que as CTH-LP estão diminuídas em humanos e camundongos idosos. ${ }^{(37)}$ Além disso foi demonstrada a redução na capacidade das CTH de camundongos idosos enxertarem em camundongos jovens, não apresentando a mesma qualidade do enxerto de quando as células são provenientes de doadores jovens, resultando em aumento da proliferação celular, expansão reduzida, acúmulo de danos ao DNA, baixo homing e enxerto, como também, um enxerto mais inclinado para à linhagem mieloide, como demonstrado na figura $4 .^{(38,39)}$ 


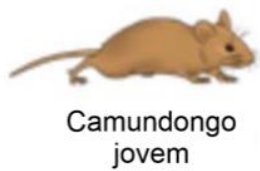

jovem

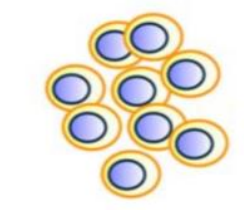

CTH
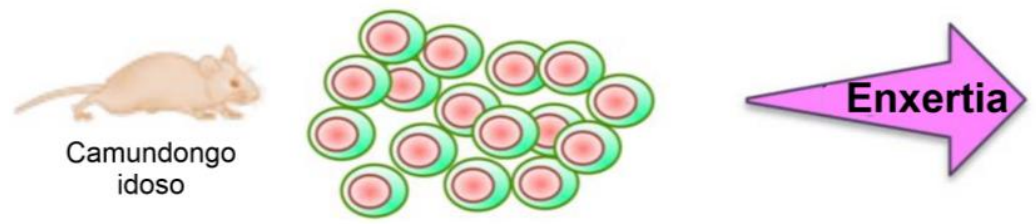
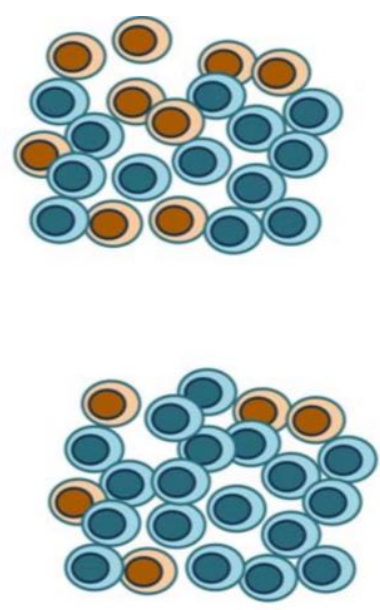

Célula mieloide

Célula linfóide

CTH: Célula-tronco hematopoiética.

Fonte: Traduzido e adaptado de Khurana S. The effects of proliferation and DNA damage on hematopoietic stem cell function determine aging. Dev Dyn. 2016;245(7):739-50. Fig. 2. Increased numbers of myeloid-biased HSCs in aged mice. p. $741 .{ }^{(39)}$

Figura 4. Diferenças do enxerto entre animais jovens e idosos, em relação a proliferação e diferenciação das células após transplante

\subsection{Nicho hematopoiético}

As $\mathrm{CTH}$ e seus precursores em maturação, antes de migrarem para o sangue periférico, estão localizados em regiões específicas da $\mathrm{MO}$, essas regiões são microambientes conhecidos como nichos hematopoiéticos. A interação das $\mathrm{CTH}$ com o microambiente medular e com as células que compõe o nicho promove sua manutenção e regula sua função. ${ }^{(40)}$

Existem dois diferentes nichos hematopoiéticos (endosteal e vascular), esses nichos são compostos por diversas células além das CTH como: células estromais mesenquimais (CEM), células de linhagem óssea, células endoteliais, células do sistema imune, células neuronais, células reticulares abundantes (CRA) em quimiocina CXC-12 (CXCL12), além de outros tipos celulares como representado na figura $5 .{ }^{(41)}$ 


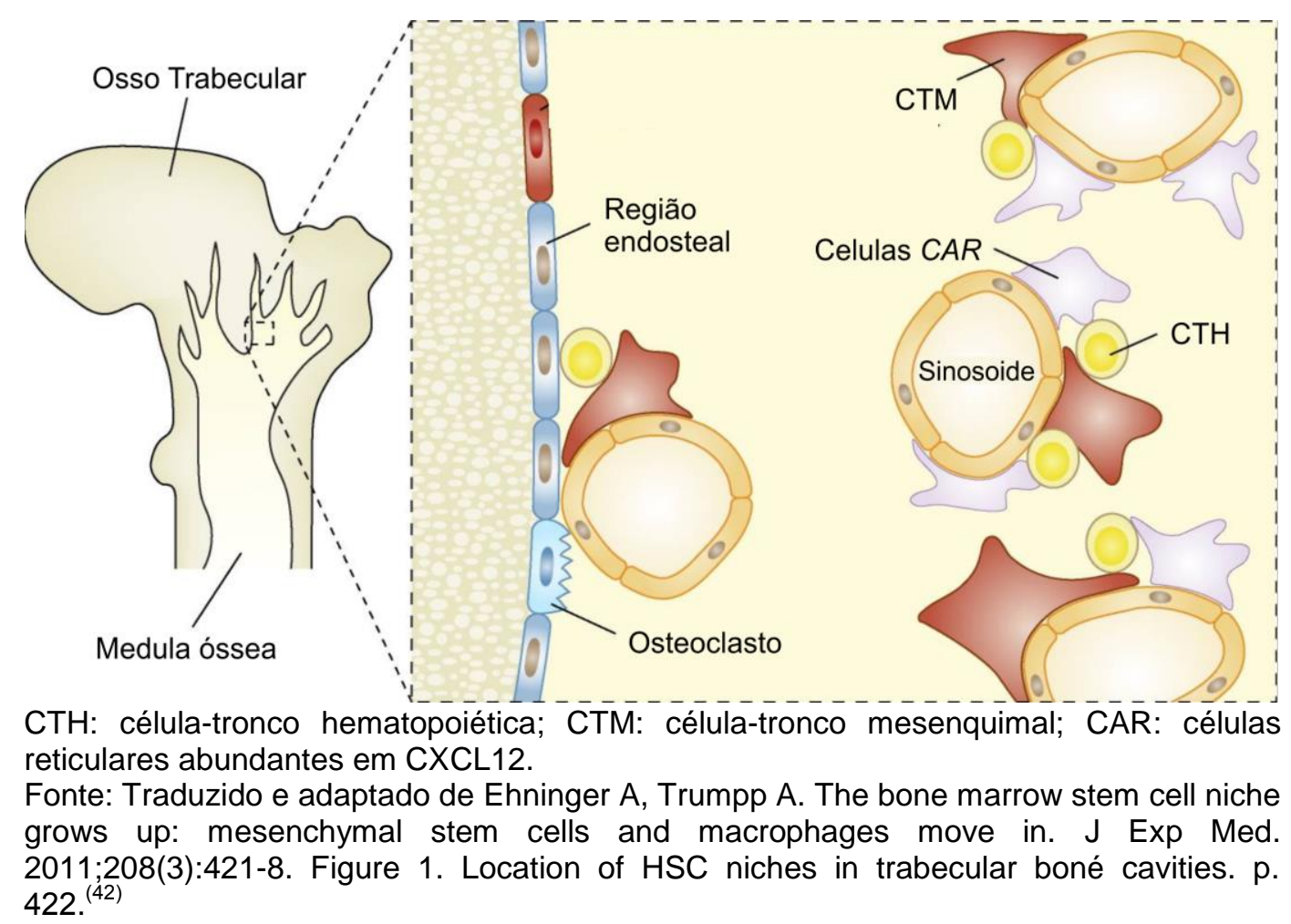

Figura 5. Localização dos nichos hematopoiéticos em cavidades ósseas trabeculares

O nicho endosteal está localizado na região da $\mathrm{MO}$ revestida por células de linhagem óssea (osteoblastos e osteoclastos) que agem no processo de formação óssea. O nicho vascular está localizado próximo ao endotélio vascular na região onde a tensão de $\mathrm{O}_{2}$ é maior, ele é composto de vasos revestidos por uma camada endotelial simples e, são responsáveis pela comunicação entre o nicho endosteal e a circulação. ${ }^{(43,44)}$

As CTH são encontradas em sua maioria adjacente aos capilares sinusóides localizados na $\mathrm{MO}$, onde células reticulares, endoteliais e mesenquimais promovem sua manutenção pela produção do fator de célula-tronco (SCF - stem cell factor) e de CXCL12 além de outros fatores. Outras células perivasculares, como as células periarteriolares Ng2-CreER+, podem sintetizar o CXCL12 necessário para a manutenção das $\mathrm{CTH} .{ }^{(45,46)}$ As $\mathrm{CTH}$ também expressam Notch, que se une ao seu ligante Jagged 1 em osteoblastos e, assim, desencadeiam sinais que contribuem para evitar sua diferenciação. ${ }^{(47)}$

Outros tipos celulares também contribuem para a regulação das CTH presentes nos nichos como: nervos simpáticos, células de Schwann não mielinizantes, macrófagos, osteoclastos, matriz extracelular e cálcio. Os osteoblastos não promovem diretamente a manutenção das $\mathrm{CTH}$, mas estão envolvidos na 
manutenção e diferenciação de progenitores linfoides pela secreção de osteopontina. $^{(45)}$

Em condições fisiológicas os nichos hematopoiéticos estão saturados de $\mathrm{CTH}$, os procedimentos de condicionamento como a $\mathrm{ICI}$ para realização do TCTH ocorrem destruindo boa parte das células presentes nos nichos, abrindo assim espaço para que ocorra o homing das CTH transplantadas para os nichos hematopoiéticos afim de reestabelecer a hematopoiese. ${ }^{(48)}$

\subsection{Homing das células-tronco hematopoiéticas para a medula óssea}

Após a realização do TCTH as CTH precisam migrar para os nichos específicos localizados na $\mathrm{MO}$, onde irão habitar e promover o reestabelecimento da hematopoiese. Esse processo de migração das CTH pelo tecido hematopoiético, através da vasculatura endotelial para diversos órgãos e os nichos hematopoiéticos presentes na $\mathrm{MO}$ é denominado homing. O homing é um processo rápido que acontece em questão de horas e não mais que 1 ou 2 dias, e é essencial para o sucesso do TCTH. ${ }^{(49)}$ Um dos principais mecanismos que direciona a migração das CTH após sua infusão no sangue periférico para os nichos localizados na $\mathrm{MO}$ envolve a interação da CXCL12 com o receptor CXCR4. O CXCR4 é um receptor acoplado à proteína G expresso na superfície das $\mathrm{CTH}$, enquanto CXCL12 é expressa principalmente pelas células endoteliais que revestem os nichos hematopoiéticos e também por osteoblastos, além de ser fundamental para o homing das CTH essa interação é muito importante para a manutenção das CTH em estado quiescente. ${ }^{(50,51)}$ Experimentos em camundongos com nocaute de CXCL12 e CXCR4 resultaram em um fenótipo letal, com vários comprometimentos sobretudo na hematopoiese. ${ }^{(52,53)}$

Grande parte dos estudos que visam obter informações in vivo sobre o homing de células após o TCTH utiliza técnicas como citometria de fluxo e microscopia confocal. ${ }^{(54)} \mathrm{O}$ uso da citometria de fluxo possibilita a quantificação de $\mathrm{CTH}$ após transplante, e permite a avaliação do nível de enxerto, mas tem a limitação quanto a exata localização das células nos órgãos. Já a microscopia confocal fornece informações sobre a distribuição espacial das células por meio de tecidos imunocorados. Ambas as técnicas só permitem analises ex vivo, não sendo possível uma avaliação in vivo em tempo real de forma não invasiva. Por isso é necessário 
encontrar técnicas que possibilitem a avaliação do homing das CTH de maneira mais eficiente do que as técnicas convencionais. ${ }^{(55)}$

Uma alternativa que vem sendo cada vez mais utilizada para o rastreamento in vivo das CTH após o TCTH é o uso de recursos nanotecnológicos. A nanotecnologia aplicada ao rastreamento de células in vivo se dá pelo uso de nanopartículas como agente de contraste para realização de $\operatorname{IRM}^{(56-58)}$ essas nanopartículas também podem ser funcionalizadas com adição de agentes fluorescentes ou de radiotraçadores, gerando nanopartículas multimodais (NPMM), que permitem o monitoramento da migração das células com o auxílio de técnicas de imagem molecular. ${ }^{(59)}$ Outra estratégia para a avaliação da migração das CTH é através da modificação das células para expressão de proteínas como a proteína verde fluorescente (GFP - green fluorescent protein) e a enzima luciferase que permitem a realização de imagens de FL e BLM, respectivamente. ${ }^{(60)}$

A avaliação da migração das $\mathrm{CTH}$ in vivo após o TMO de forma não invasiva através destas técnicas podem gerar dados sobre a cinética do enxerto, permitindo a avaliação de fatores que interfiram na migração das células para o local de interesse, sendo assim útil para buscar estratégias que auxilie na melhora dos processos de transplante e enxerto. ${ }^{(61)}$

\subsection{Nanotecnologia aplicada ao rastreamento celular}

A nanotecnologia é uma ciência que está envolvida no projeto, síntese, caracterização e utilização de materiais em escala nanométrica, denominados nanomateriais. O uso desses nanomateriais na área da Medicina tem aplicação para fins preventivo, terapêutico, diagnóstico e teranóstico. ${ }^{(62,63)}$ Dentre os nanomateriais utilizados podemos destacar as nanopartículas que possibilitam a conjugação, encapsulação ou adsorção de vários agentes como agentes radioativos, fluoróforos, peptídeos, pequenas moléculas orgânicas, quimioterápicos, anticorpos, entre outros, o

que lhes confere grande aplicabilidade em diversas áreas da Medicina. ${ }^{(64,65)}$

Existe uma série de nanopartículas utilizadas para marcação celular, por exemplo: nanopartículas orgânicas como lipossomos, micelas, polímeros, dendrímeros, e nanopartículas inorgânicas como ouro, prata, óxido de ferro, pontos quânticos (quantum dots), entre outras (Figura 6). Cada nanopartícula com tamanho, 
forma, composição e propriedades diferentes, apresentando vantagens e desvantagens de acordo com a aplicação. ${ }^{(66,67)}$

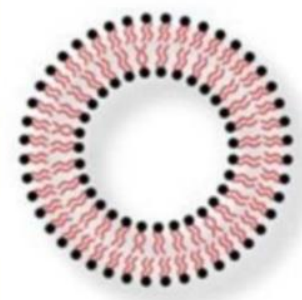

Liposomos

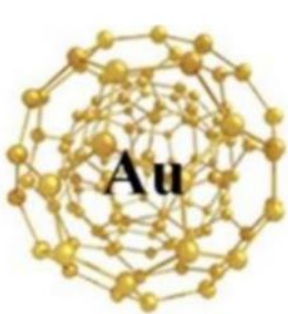

Ouro

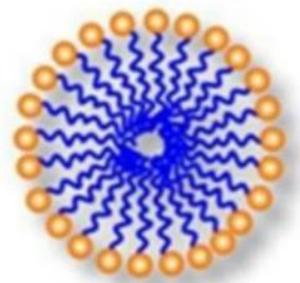

Miscelas

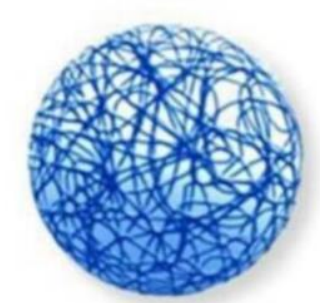

Poliméricas

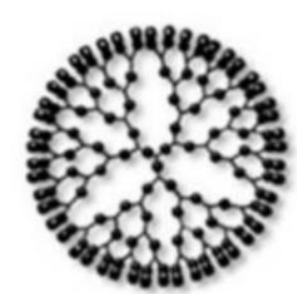

Dendrímeros

\section{Nanopartículas inorgânicas}

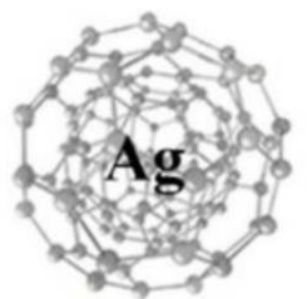

Prata

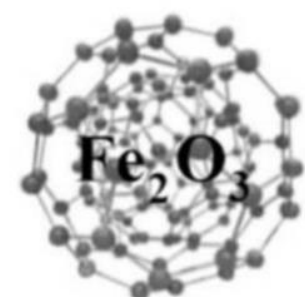

Óxido de ferro

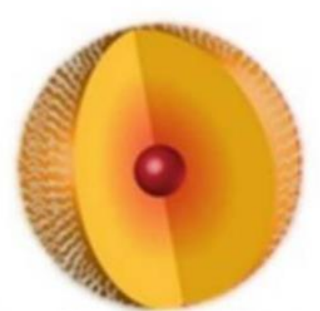

Quantum Dots

Fonte: Traduzido e adaptado de Itani R, Al Faraj A. siRNA conjugated nanoparticles-a next generation strategy to treat lung cancer. Int J Mol Sci. 2019;20(23):6088 ${ }^{(67)}$

Figura 6. Diferentes nanopartículas orgânicas e inorgânicas utilizadas para marcação celular

As nanopartículas aplicadas ao rastreamento não invasivo in vivo de CTH permite acompanhar sua localização por determinado tempo, além de ser um método sensível e que não causa citotoxicidade. Atualmente, o uso de nanopartículas para rastreamento de células-tronco está limitado a estudos pré-clínicos, para a utilização das nanopartículas como agente de rastreamento no uso clínico, é necessário o entendimento de curto e longo prazo de sua influência na viabilidade celular após marcação, influência na migração, diferenciação e capacidade da célula enxertar. $^{(68)}$

Dentre as nanopartículas utilizadas para o rastreamento de CTH podemos destacar as nanopartículas superparamagnéticas de óxido de ferro (NSOF), que possuem a propriedade do superparamagnetismo. Além disso, a síntese das NSOF é relativamente fácil, além da possibilidade de tornar sua superfície biocompatível e adicionar vários agentes como fluoróforos e radiotraçadores para tornar as NSOF multifuncionais. ${ }^{(69)}$ 


\subsubsection{Nanopartículas superparamagnéticas de óxido de ferro}

As NSOF são as nanopartículas metálicas mais utilizadas na nanomedicina, em comparação com as nanopartículas de ouro, são consideravelmente mais baratas além de serem mais biocompatíveis. ${ }^{(70)}$

As NSOF são compostas por um núcleo de óxido de ferro geralmente de magnetita $\left(\mathrm{Fe}_{3} \mathrm{O}_{4}\right)$, maghemita $\left(\mathrm{\gamma}-\mathrm{Fe}_{2} \mathrm{O}_{3}\right)$ ou hematita $\left(\alpha-\mathrm{Fe}_{2} \mathrm{O}_{3}\right),{ }^{(71)} \mathrm{com}$ uma camada de revestimento biocompatível que pode ser composta por diferentes materiais como polietilenoglicol (PEG), álcool polivinílico (PVA - polyvinyl alcohol), polivinilpirrolidona (PVP), dextrana, quitosana, pululano, alginato, entre outras. ${ }^{(72)} A$ representação de uma NSOF é mostrada na figura 7, onde o diâmetro da nanopartícula é formado pelo núcleo e a sua cobertura. Quando a nanopartícula estiver funcionalizada temos o denominado diâmetro hidrodinâmico que corresponde à dimensão total da nanopartícula. ${ }^{(73)}$

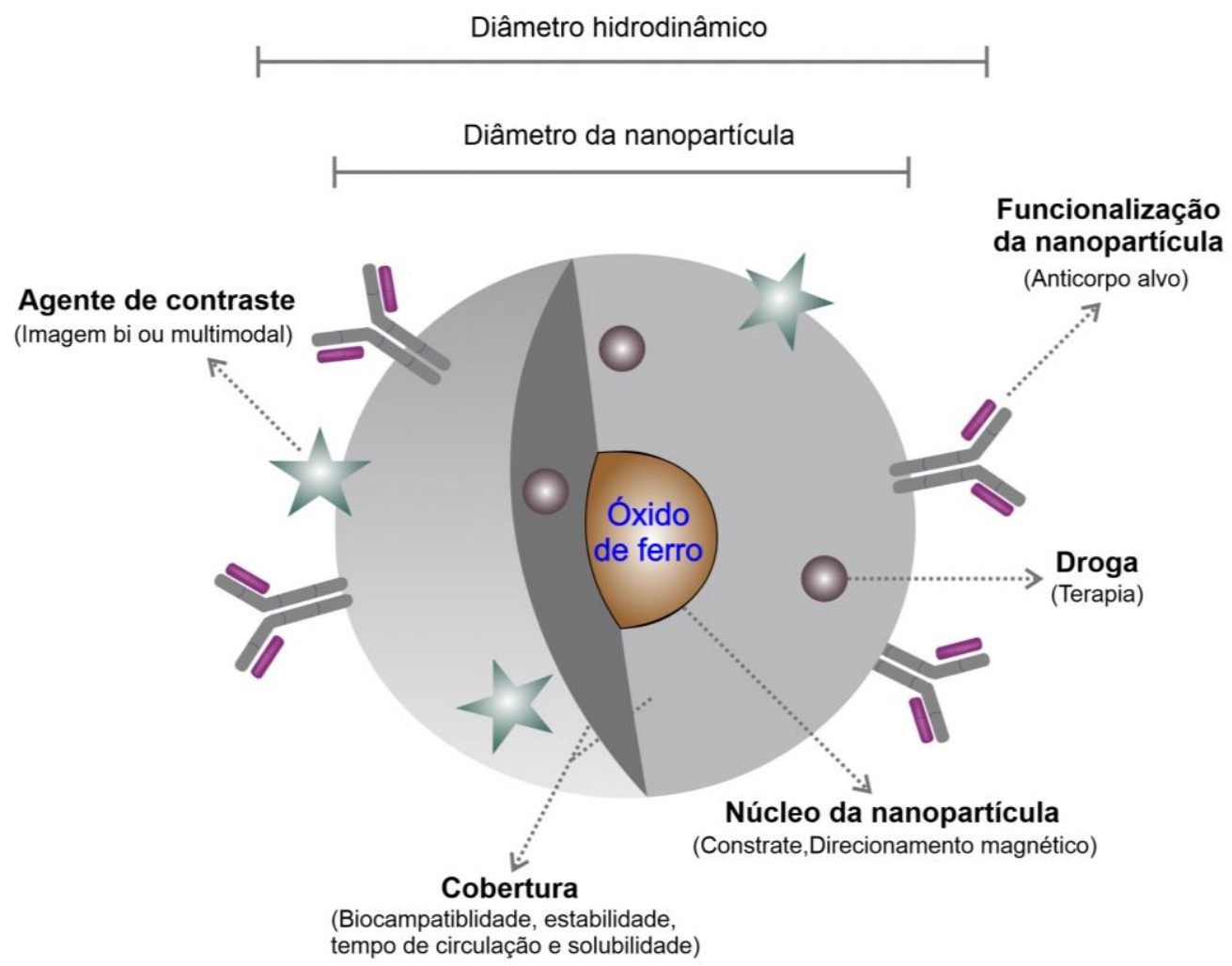

Fonte: Traduzido e adaptado de Bakhtiary Z, Saei AA, Hajipour MJ, Raoufi M, Vermesh O, Mahmoudi M. Targeted superparamagnetic iron oxide nanoparticles for early detection of cancer: possibilities and challenges. Nanomedicine. 2016;12(2):287-307. ${ }^{(73)}$

Figura 7. Representação de uma nanopartícula magnética de oxido de ferro (núcleo), que apresenta uma cobertura com caráter biocompativel, que pode ser funcionalizado à superfície para direcionar ao alvo específico além de ser utilizado como contraste pode ser utilizado para processos terapêuticos 
Outra característica das NSOF é apresentar a propriedade do superparamagnetismo. Materiais que possuem essa propriedade têm como característica possuir momentos magnéticos desorganizados que apontam em direções opostas quando um campo magnético forte é aplicado, esses momentos magnéticos se alinham na mesma direção e o material se magnetiza, uma vez que o campo é retirado o material se desmagnetiza, essa propriedade tem influência direta do tamanho, por isso que nanopartículas entre 10 a $20 \mathrm{~nm}$ tendem a exibir monodomínios que possibilitam uma resposta magnética mais rápida, quando comparada a nanopartículas maiores que possuem diâmetro crítico gerando multidomínios. ${ }^{(74)}$

Ainda não se tem total entendimento sobre a forma com que é realizada a marcação das células com as NSOF a nível molecular, entretanto, é sabido que a marcação das células se dá por duas formas: ligação à membrana das células e internalização celular (endocitose ou fagocitose). A marcação das nanopartículas por ligação a membrana gera grande possibilidade de eliminação pelas células após o transplante invalidando o monitoramento, portanto, a internalização é o modo mais seguro de marcação das células por nanopartículas, a fagocitose fica restrita a células fagocíticas como monócitos, macrófagos, neutrófilos e células dendríticas e, a internalização por processo de endocitose pode ser realizada por receptores de membrana, internalização independente de clatrina e caveolina, internalização mediada por clatrina, internalização mediada por caveolina, e internalização mediada por agente de transfecção como poli-L-lisina (PLL). ${ }^{(75,76)}$

As NSOF são muito utilizadas como agentes de contraste para realização de técnicas imagens molecular, no caso da IRM ela aumenta o contraste entre os tecidos. As células marcadas com NSOF geram um forte contraste em imagens hipointensas ponderadas em mapas de tempo de relaxação spin-spin (T2), quando funcionalizadas também possibilitam 0 rastreamento in vivo de células transplantadas por outras modalidades de imagem molecular como imagem de FL e técnicas de imagem nuclear. ${ }^{(77)}$

\subsection{Imagem molecular para o rastreamento de processos biológicos}

A imagem molecular compreende um grupo de técnicas de imagem que utilizam moléculas alvo para o rastreamento de processos biológicos em análises 
in vivo. O uso de técnicas de imagem molecular permite a realização de imagens não invasivas e análises quantitativas. ${ }^{(78)}$

As técnicas de imagem molecular podem ser divididas em:

I. Imagem por ressonância magnética;

II. Imagem nuclear: PET e SPECT;

III. Imagem ótica: imagem de BLM e imagem de FL no espectro infravermelho. Sendo que cada uma dessas técnicas requer agentes próprios para marcação e posterior rastreamento. ${ }^{(79)}$ Exemplos de agentes de rastreamento para cada técnica podem ser visualizados na figura 8 .
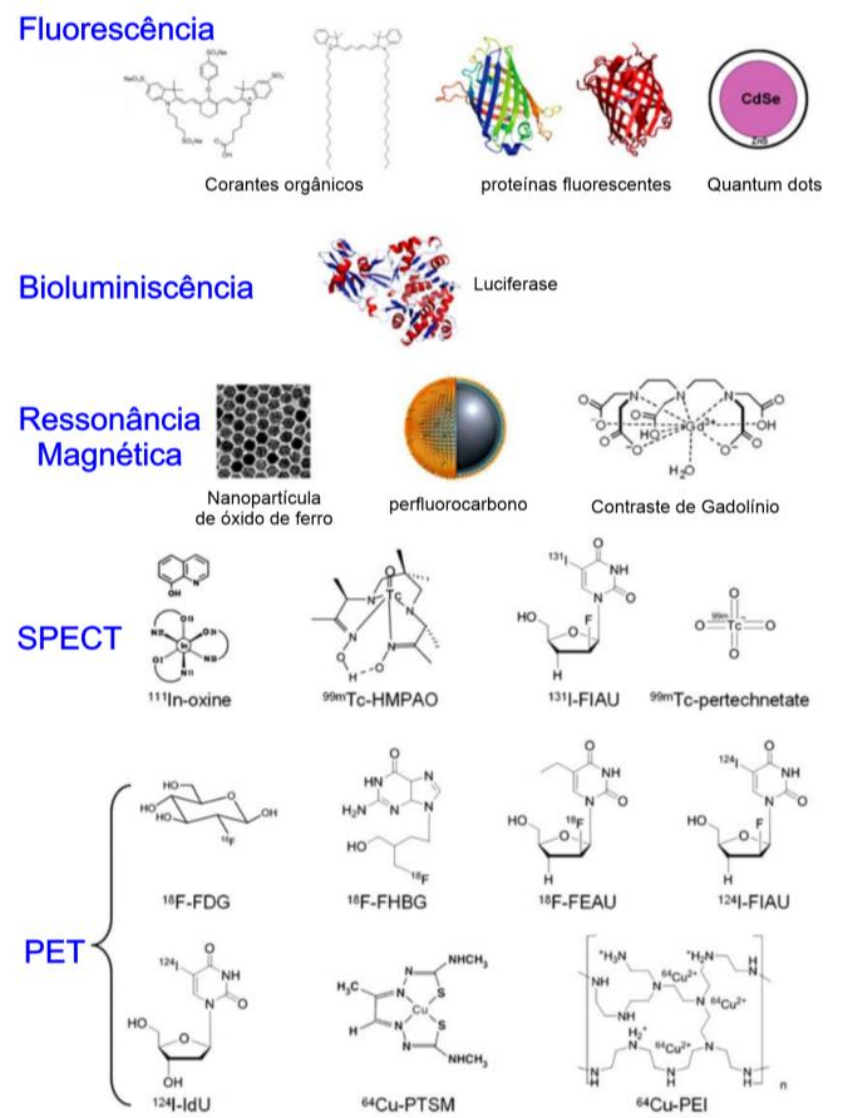

PET: tomografia por emissão de pósitrons; SPECT: tomografia computadorizada com emissão de fóton único.

Fonte: Traduzido e adaptado de Hong $\mathrm{H}$, Yang $\mathrm{Y}$, Zhang $Y$, Cai W. Non-invasive cell tracking in cancer and cancer therapy. Curr Top Med Chem. 2010;10(12):1237-48. Fig. (1). Many imaging labels and techniques have been used to label cells and track them in vivo. Some involve direct labeling of the cells while others require genetic modification of the cells. p. $1238 .{ }^{(80)}$

Figura 8. Agentes de rastreamento utilizados pelas diferentes técnicas de imagem molecular 
A realização de qualquer uma das técnicas citadas acima depende da marcação das células por um agente que permita seu rastreamento, sendo que duas abordagens são utilizadas para realizar a marcação celular: marcação direta e indireta. ${ }^{\left({ }^{81}\right)} \mathrm{A}$ marcação direta geralmente é mais simples, e se dá pela incorporação in vitro do agente de rastreamento como: nanopartículas, fluoróforos ou radiotraçadores. Já a marcação indireta ocorre através da modificação genética para que a célula passe a produzir internamente uma molécula como, por exemplo, luciferase ou GFP, essa marcação é mais complexa por necessitar de habilidades em outras técnicas para a marcação. ${ }^{(71)} \mathrm{O}$ quadro 1 indica as características favoráveis e desfavoráveis segundo cada tipo de marcação.

Quadro 1. Vantagens e desvantagens das marcações diretas e indiretas das célula-tronco hematopoiéticas por agentes de rastreamento

\begin{tabular}{|c|c|}
\hline Marcação direta & Marcação indireta \\
\hline Relativamente fácil & Requer habilidades técnicas especializadas \\
\hline $\begin{array}{l}\text { Geralmente envolve cultura de células } \\
\text { ex vivo }\end{array}$ & Envolve cultura celular ex vivo \\
\hline $\begin{array}{l}\text { Não requer nenhuma manipulação genética } \\
\text { necessária }\end{array}$ & Requer experiência em biologia molecular \\
\hline Custo mais acessível & Mais caro \\
\hline Risco reduzido de manipulação & $\begin{array}{l}\text { Requer um nível de biossegurança maior devido à } \\
\text { manipulação de vetores retro ou lentivirais e no } \\
\text { descarte de materiais }\end{array}$ \\
\hline Sem risco direto de mutagênese & Risco de mutagênese nas células transformadas \\
\hline $\begin{array}{l}\text { Sinal do agente de rastreamento desaparece } \\
\text { com o tempo }\end{array}$ & $\begin{array}{l}\text { O sinal é mantido por longos períodos em } \\
\text { transformação estável (excluindo a possibilidade de } \\
\text { silenciamento de genes) }\end{array}$ \\
\hline $\begin{array}{l}\text { O agente de marcação é diluído nas células } \\
\text { filhas }\end{array}$ & $\begin{array}{l}\text { O agente de marcação continua a ser produzido } \\
\text { pelas células filhas (em transformação estável) }\end{array}$ \\
\hline $\begin{array}{l}\text { Não fornece informações sobre proliferação } \\
\text { celular in vivo }\end{array}$ & $\begin{array}{l}\text { Permite avaliação da proliferação celular (em } \\
\text { transformação estável) }\end{array}$ \\
\hline $\begin{array}{l}\text { O marcador pode ser difundido para hospedar } \\
\text { tecidos e hospedar células não-alvo }\end{array}$ & $\begin{array}{l}\text { Sinal gerado apenas nas células inicialmente } \\
\text { preparadas }\end{array}$ \\
\hline Facilmente traduzível para uso em humanos & Não aplicável em humanos \\
\hline
\end{tabular}

Fonte: Traduzido e adaptado de Jasmin, de Souza GT, Louzada RA, Rosado-de-Castro PH, MendezOtero R, Campos de Carvalho AC. Tracking stem cells with superparamagnetic iron oxide nanoparticles: perspectives and considerations. Int J Nanomedicine. 2017;12:779-93. ${ }^{(71)}$

$\mathrm{O}$ uso de técnicas de imagem molecular para rastreamento de $\mathrm{CTH}$ teve início, com estudos que visavam avaliar, sobretudo a capacidade de enxerto das $\mathrm{CTH}^{\left({ }^{82)}\right.}$ Com o avanço das técnicas de imagem também se tornou possível o monitoramento agudo da migração das $\mathrm{CTH}$ in vivo. ${ }^{(57,83)} \mathrm{A}$ avaliação da migração das CTH após o TMO auxilia no entendimento do homing e pode aprimorar estudos tanto pré-clínicos, como clínicos de TCTH. 
Cada uma das técnicas de imagem molecular possui suas vantagens e desvantagens, tanto para marcação quanto para aquisição das imagens, portanto, a combinação entre técnicas de imagem ótica, IRM e imagem nuclear auxilia no desenvolvimento de sondas que contenham potencial para traduzir informações anatômicas, funcionais e metabólicas, que em muitos casos somente uma modalidade de imagem não seria capaz de evidenciar. ${ }^{(84,85)}$

\subsubsection{Imagem por ressonância magnética}

A IRM é uma técnica não invasiva, muito utilizada para realização de imagens em seres humanos para fins de diagnóstico. ${ }^{(86)}$ A IRM tem como base a interação do campo magnético com os prótons de hidrogênio do tecido, o sinal obtido é coletado através de uma bobina que é processado e convertido em imagem. ${ }^{(87)}$

Os prótons de hidrogênio presentes nos tecidos estão em momentos magnéticos distintos apontando para várias direções de forma que seus momentos magnéticos acabam sendo cancelados, quando um campo magnético forte é aplicado, os prótons se movimentam ao redor do seu eixo (spin) fazendo com que os momentos magnéticos apontem para uma só direção, a liberação de energia obtida por esse processo se chama relaxação, que pode ocorrer de duas formas: relaxação spin-rede (T1) e T2 (Figura 9). ${ }^{(86)}$ Na figura 9 é observado o processo de T2 (em azul) onde existe uma interação entre os spins, apresentando um sinal inicialmente intenso e um posterior decaimento do sinal (magnetização transversal $\left[\mathrm{M}_{\mathrm{T}}\right]$ ) como mostrada na parte central da figura 9, através do decaimento exponencial governada pelo tempo T2. Quando um tecido possui a presença das nanopartículas magnéticas é possível verificar o decaimento do sinal rapidamente como é mostrado na figura 10, onde dependendo do tempo do eco (TE) é possível obter um melhor contraste como é mostrada nas áreas 1 e 2 no gráfico da figura 10, que representam tecido sem e com nanopartículas magnéticas respectivamente. ${ }^{(88)}$ 


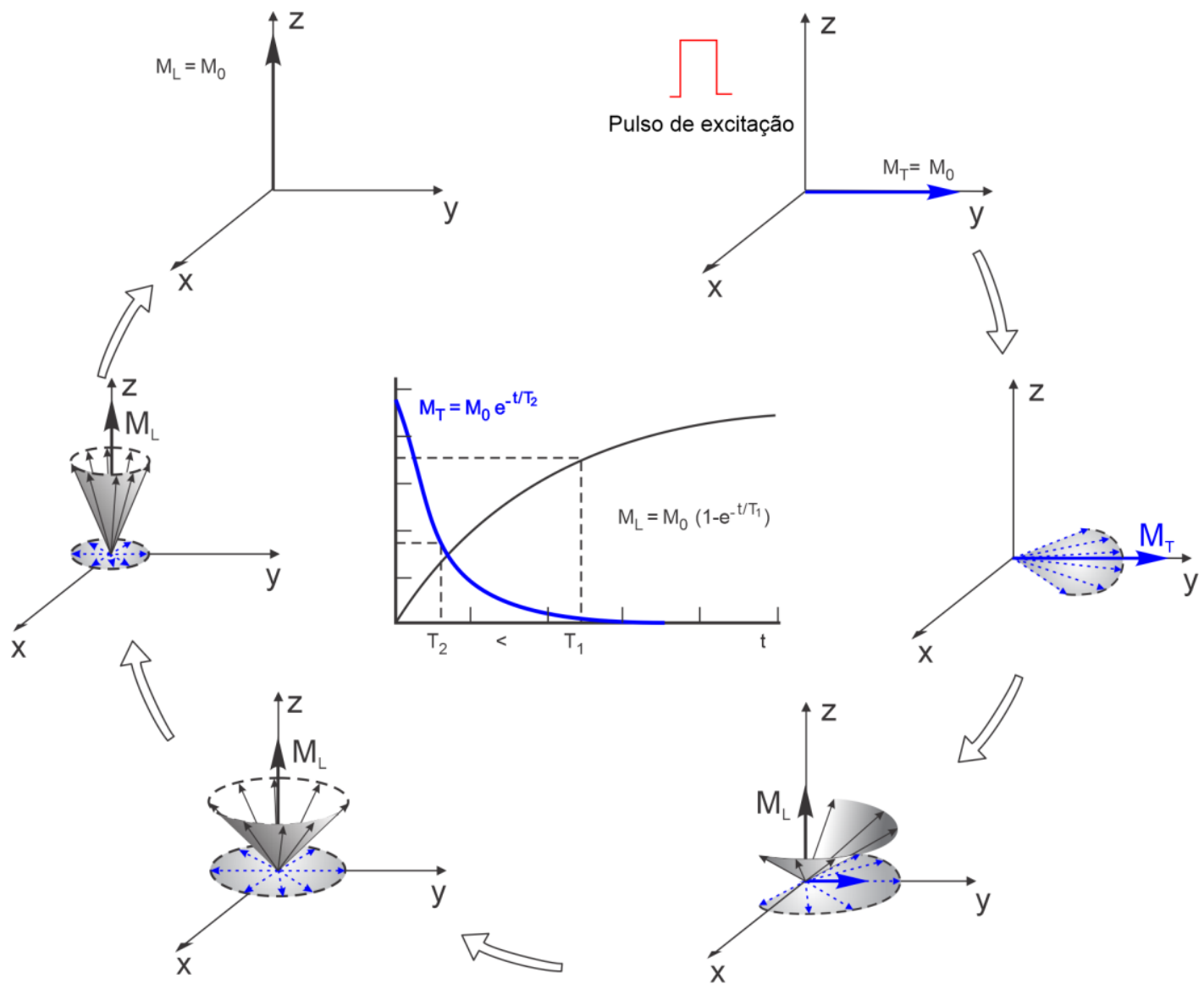

z: Eixo z. x: Eixo x. y: Eixo y. $M_{L}$ : Magnetização longitudinal. $M_{T}$ : Magnetização transversal. $\mathrm{M}_{0}$ : Magnetização inicial. T1: relaxação spin-rede. T2: relaxação spin-spin.

Fonte: Adaptado de Contreras LF. Espectroscopia por ressonância magnética nuclear localizada: projeto e implementação [dissertação]. São Paulo: Universidade de São Paulo; 2001. ${ }^{(89)}$

Figura 9. Processo de relaxação T1 e T2, em função das mudanças das magnetizações longitudinal e transversal a partir de um pulso de excitação de radiofrequência, onde inicialmente possui uma magnetização inicial, processo que acontece para a obtenção do sinal do sinal de ressonância magnética

Portanto, os agentes de contraste são utilizados para melhorar a visualização da imagem, o que implica em melhora da sensibilidade e da especificidade, ${ }^{(90)}$ as NSOF podem ser utilizados como agentes de contraste para imagens principalmente em T2, gerando um sinal hipointenso e aumentando o contraste entre os tecidos que pode ser utilizado na avaliação do homing e rastreamento das $\mathrm{CTH}$ marcadas. ${ }^{(68)}$ 

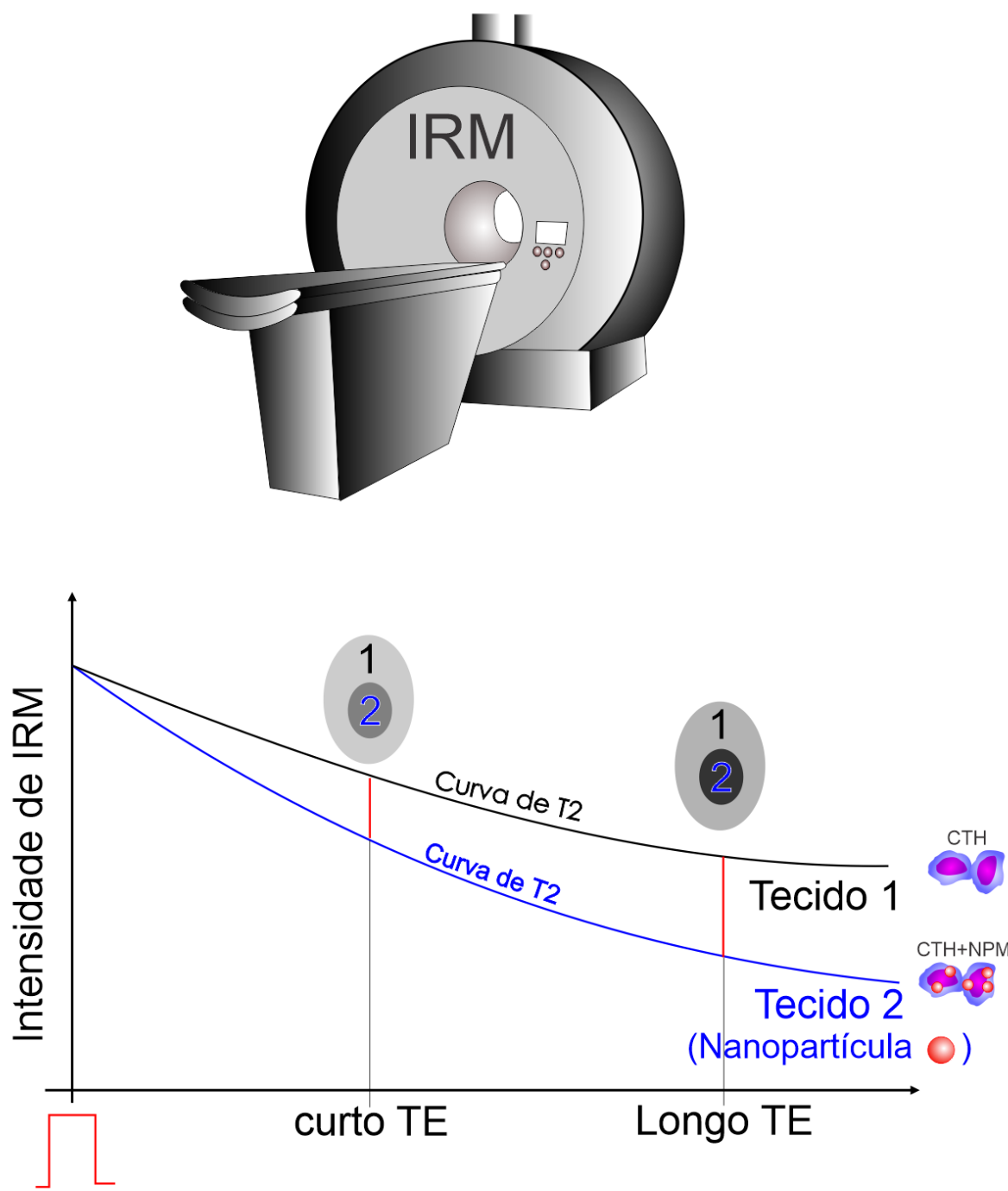

\section{Pulso de excitação}

IRM: imagem de ressonância magnética; T2: relaxação spin-spin; TE: tempo de eco; CTH: célula-tronco hematopoiética NPM: nanopartícula magnética.

Fonte: Traduzido e adaptado de Oliveira FA, Nucci MP, Filgueiras IS, Ferreira JM, Nucci LP, Mamani JB, et al. Noninvasive tracking of hematopoietic stem cells in a bone marrow transplant model. Cells. 2020;9(4):939. (91) $^{2}$

Figura 10. Curvas de T2 mostrando a diferença entre as curvas na ausência e presença de nanopartículas magnéticas como contraste tanto para curtos e longos de tempo de eco, a partir de pulsos de excitação

Podemos observar na tabela 1 que a IRM tem uma alta resolução espacial $(0,02-0,01 \mathrm{~mm})$, uma resolução temporal de minutos a horas, penetração tecidual ilimitada e sensibilidade na faixa de $10^{-3}-10^{-5} \mathrm{~mol} / \mathrm{L}$. Não necessita de exposição à radiação como as técnicas de imagem nuclear e é uma técnica de imagem de fácil translação da pesquisa pré-clínica para a clínica. Em contrapartida, a IRM apresenta um alto custo e baixa sensibilidade. 
Tabela 1. Principais características das técnicas de imagem molecular

\begin{tabular}{|c|c|c|c|c|c|c|c|c|c|c|c|c|}
\hline $\begin{array}{l}\text { Tipo de } \\
\text { imagem }\end{array}$ & Técnica & $\begin{array}{l}\text { Princípio } \\
\text { físico }\end{array}$ & Traçador & $\begin{array}{l}\text { Imagem } \\
\text { In vitro }\end{array}$ & $\begin{array}{l}\text { Imagem } \\
\text { pré- } \\
\text { clínica }\end{array}$ & $\begin{array}{l}\text { Imagem } \\
\text { clínica }\end{array}$ & $\begin{array}{l}\text { Resolução } \\
\text { espacial }\end{array}$ & $\begin{array}{l}\text { Tempo de } p \\
\text { aquisição } d\end{array}$ & $\begin{array}{l}\text { rofundidade } \\
\text { penetração }\end{array}$ & Sensibilidade & Vantagens & Desvantagens \\
\hline \multirow{2}{*}{$\begin{array}{l}\text { Imagem } \\
\text { ótica }\end{array}$} & BLM & Luz visível & $\begin{array}{l}\text { Proteínas } \\
\text { luminescentes }\end{array}$ & Sim & Sim & Não & $3-5 \mathrm{~mm}$ & $\begin{array}{l}\text { Segundos } \\
\text { a minutos }\end{array}$ & $1-2 \mathrm{~cm}$ & Alta+++ & $\begin{array}{l}\text { Alta sensibilidade, não } \\
\text { radioativa, expansão celular }\end{array}$ & $\begin{array}{l}\text { Baixa profundidade de } \\
\text { penetração, não } \\
\text { translacional }\end{array}$ \\
\hline & $\mathrm{FL}$ & $\begin{array}{l}\text { Luz visível ou } \\
\text { no } \\
\text { infravermelho } \\
\text { próximo }\end{array}$ & $\begin{array}{l}\text { Proteínas ou } \\
\text { corantes } \\
\text { fluorescentes }\end{array}$ & Sim & Sim & Não & $2-3 m m$ & $\begin{array}{l}\text { Segundos } \\
\text { a minutos }\end{array}$ & $<1 \mathrm{~cm}$ & Alta++ & $\begin{array}{l}\text { Alta sensibilidade, não } \\
\text { radioativa }\end{array}$ & $\begin{array}{l}\text { Baixa profundidade de } \\
\text { penetração, } \\
\text { autofluorescência }\end{array}$ \\
\hline \multirow{2}{*}{$\begin{array}{l}\text { Imagem } \\
\text { nuclear }\end{array}$} & PET & $\begin{array}{l}\text { Raios- } \gamma \text { - de } \\
\text { alta energia }\end{array}$ & $\begin{array}{l}\text { Radioisótopos } \\
\text { (89Zr, 18F, } \\
\text { 11C, 64Cu, } \\
\text { 68GA) }\end{array}$ & Não & Sim & Sim & $1-2 m m$ & Minutos & Ilimitada & Alta++ & $\begin{array}{l}\text { Alta profundidade de } \\
\text { penetração, alta sensibilidade }\end{array}$ & $\begin{array}{c}\text { Exposição à radiação, alto } \\
\text { custo }\end{array}$ \\
\hline & SPECT & $\begin{array}{c}\text { Raios- } \gamma-\mathrm{de} \\
\text { baixa energia }\end{array}$ & $\begin{array}{c}\text { Radioisótopos } \\
\text { (99mTc, 123I, } \\
111 \mathrm{ln})\end{array}$ & Não & Sim & Sim & $1-2 m m$ & Minutos & Ilimitada & Alta++ & $\begin{array}{c}\text { Alta profundidade de } \\
\text { penetração, alta sensibilidade }\end{array}$ & $\begin{array}{c}\text { Exposição à radiação, alto } \\
\text { custo }\end{array}$ \\
\hline $\begin{array}{l}\text { Imagem } \\
\text { magnética }\end{array}$ & IRM & $\begin{array}{l}\text { Ondas de } \\
\text { rádio }\end{array}$ & $\begin{array}{l}\text { Agentes de } \\
\text { contraste }\end{array}$ & Não & Sim & Sim & $0,02-0,1 \mathrm{~mm}$ & $\begin{array}{l}\text { Minutos a } \\
\text { horas }\end{array}$ & Ilimitada & Baixa & $\begin{array}{l}\text { Alta profundidade de } \\
\text { penetração, não radioativa, } \\
\text { alta resolução espacial }\end{array}$ & $\begin{array}{l}\text { Alto custo, baixa } \\
\text { sensibilidade }\end{array}$ \\
\hline
\end{tabular}

BLM: bioluminescência; FL: fluorescência; PET: tomografia por emissão de pósitrons; SPECT: tomografia computadorizada com emissão de fóton único; IRM: imagem de ressonância magnética; 89Zr: Zircônio-89; 18F: Flúor-18; 11C: Carbono-11; 64CU: Cobre-64; 68GA: Gálio-68; 99mTc: Tecnécio-99 metaestável; 123I: lodo-123; 111 In: Índio-111.

Fonte: Traduzido e adaptado de Nucci MP, Filgueiras IS, Ferreira JM, de Oliveira FA, Nucci LP, Mamani JB, et al. Stem cell homing, tracking and therapeutic efficiency evaluation for stroke treatment using nanoparticles: a systematic review. World J Stem Cells. 2020;12(5):381-405. Table 1. Molecular imaging modalities. p. 384. ${ }^{(92)}$ 


\subsubsection{Técnicas de imagem nuclear}

As técnicas de imagem nuclear, PET e SPECT, representam outra modalidade de imagem molecular utilizada para rastreamento não invasivo de células após transplante já aplicada a área clínica. ${ }^{(93-96)}$ Ambas as técnicas são realizadas com tomógrafos ou aparelhos de ressonância magnética acoplados que permitem a realização de imagens metabólicas e anatômicas, o que possibilita a análise da distribuição das células-tronco marcadas, gerando imagens tridimensionais. ${ }^{\left({ }^{(2)}\right.}$

As imagens PET e SPECT dependem do uso de radiotraçadores para marcação das células antes do transplante, para tal é de grande importância escolher o radiotraçador correto, já que eles possuem meia-vida diferentes. Entre os principais radiotraçadores utilizados para o rastreamento de células e suas respectivas meias-vidas, temos: Gálio-68: 68 minutos, Flúor-18: 109 minutos, Tecnécio-99m: 6 horas, Cobre-64: 12 horas, e Lutécio-117: 6,7 dias. ${ }^{(98,99)}$

Quanto às características técnicas das imagens de PET e SPECT, podemos observar na tabela 1 que ambas têm boa resolução espacial (1-2mm), uma resolução temporal de minutos, penetração tecidual ilimitada e alta sensibilidade, no caso do PET, na faixa de $10^{-11}-10^{-12} \mathrm{~mol} / \mathrm{L}$ e no SPECT na faixa de $10^{-10}-10^{-11} \mathrm{~mol} / \mathrm{L}$, além de serem técnicas de imagem de fácil translação para a prática clínica. Em contrapartida, as imagens nucleares têm um alto custo e requer a exposição à radiação ionizante. A figura 11 mostra os princípios das técnicas de PET e SPECT que resultam do decaimento de átomos instáveis, no caso do PET ocorre o processo de aniquilamento dos prótons que gera raios gama, já na técnica de SPECT o radioisótopo emite o fóton gama que é detectado por uma câmera gama. ${ }^{(100)}$ 


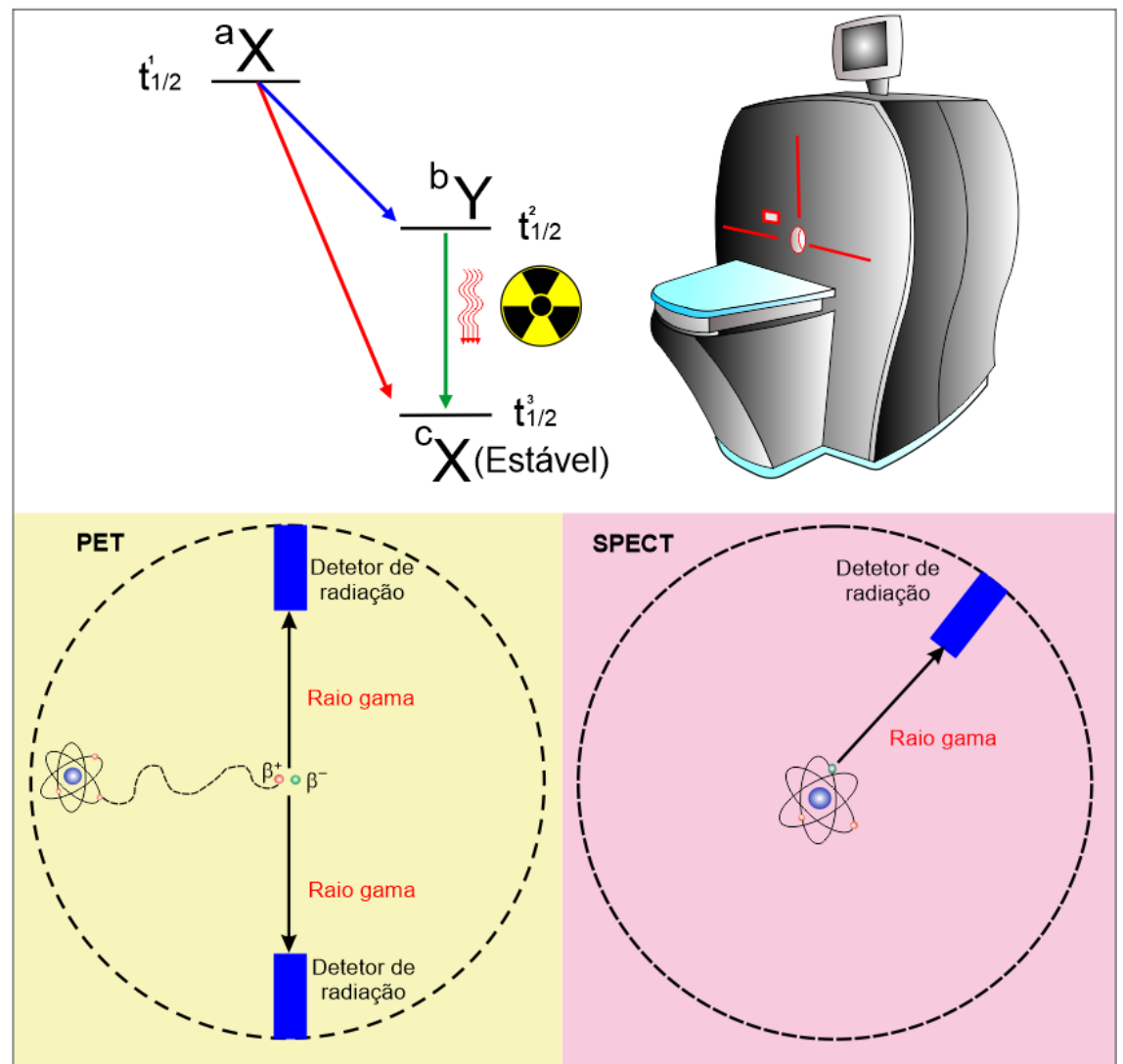

PET: tomografia por emissão de pósitrons. SPECT: tomografia computadorizada por emissão de fóton único.

Fonte: Traduzido e adaptado de Oliveira FA, Nucci MP, Filgueiras IS, Ferreira JM, Nucci LP, Mamani JB, et al. Noninvasive tracking of hematopoietic stem cells in a bone marrow transplant model. Cells. 2020;9(4):939. ${ }^{(91)}$

Figura 11. Princípio das técnicas de tomografia por emissão de pósitrons e tomografia computadorizada por emissão de fóton único

\subsubsection{Imagem ótica}

\subsubsection{Imagem de bioluminescência}

A BLM é um fenômeno natural de emissão de luz realizado por uma série de organismos vivos. Este fenômeno ocorre quando há interação entre dois componentes principais, a enzima luciferase e seu substrato a luciferina, que em condições adequadas tem a capacidade de emitir luz (Figura 12). ${ }^{(101)}$ 


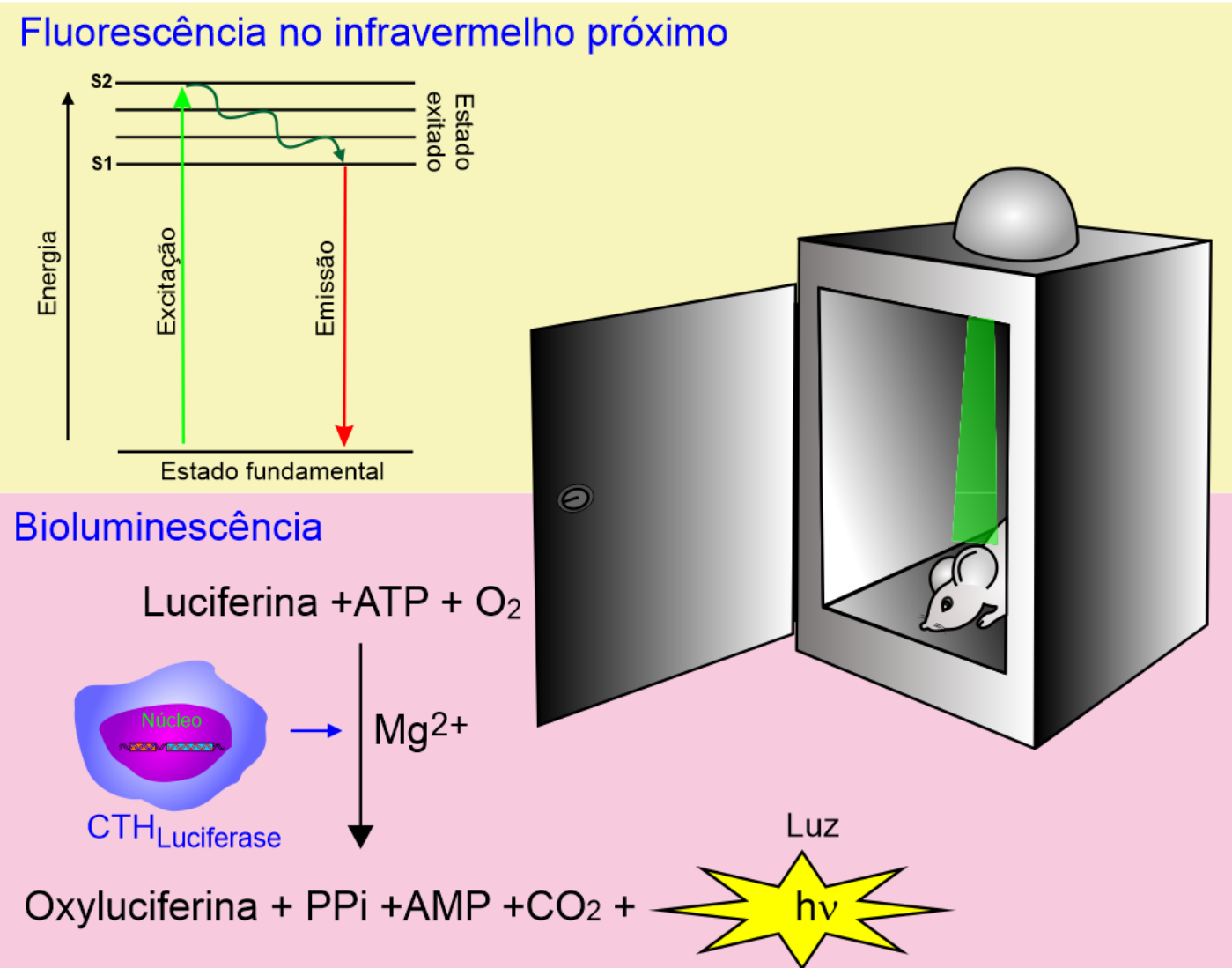

Fonte: Traduzido e adaptado de Oliveira FA, Nucci MP, Filgueiras IS, Ferreira JM, Nucci LP, Mamani JB, et al. Noninvasive tracking of hematopoietic stem cells in a bone marrow transplant model. Cells. 2020;9(4):939. ${ }^{(91)}$

Figura 12. Princípio das técnicas de imagem ótica

As luciferases são uma família de fotoproteínas presentes em uma grande variedade de insetos, organismos marinhos e procariontes. A principal luciferase utilizada para realização de imagens óticas é a luciferase de vagalume (FLuc - Firefly luciferase) que oxida seu substrato d-luciferina na presença de ATP, Mg2 e $\mathrm{O}_{2}$ para gerar luz no comprimento de onda de 562nm. Algumas luciferases, Renilla luciferase/Gaussia luciferase (RLuc/GLuc), de animais marinhos que vivem em águas profundas, utilizam a luciferina chamada coelenterazina como substrato e catalisam a reação somente na presença de $\mathrm{O}_{2}$, gerando luz no comprimento de onda de $480 \mathrm{~nm}$ (Figura 13). Já as luciferases bacterianas têm como característica não utilizar substrato exógenos para emissão de luz. ${ }^{(102)}$ 


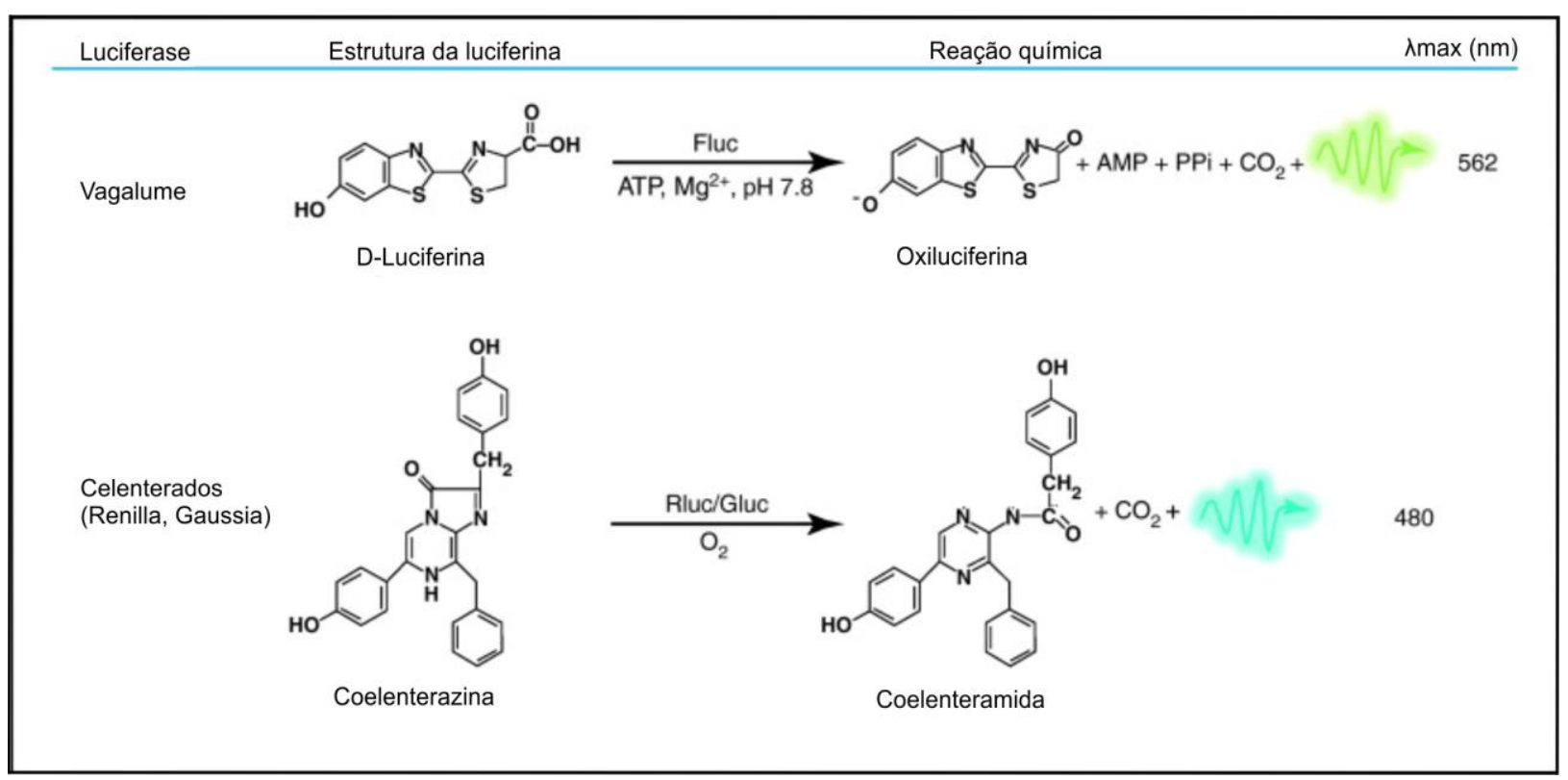

Fonte: Traduzido e adaptado de Badr CE, Tannous BA. Bioluminescence imaging: progress and applications. Trends Biotechnol. 2011;29(12):624-33. Figure 1. Bioluminescence reactions of Fluc, Rluc and Gluc. p. 625. ${ }^{(103)}$

Figura 13. Reação química que ocorre na bioluminescência entre luciferase e luciferina para geração de luz

O uso da imagem de BLM em ensaios in vivo permite 0 monitoramento da migração celular, por meio da representação visual da BLM gerada pela oxidação da luciferina pela enzima luciferase, fornecendo um perfil da dinâmica das células transplantadas e sua proliferação em animais receptores vivos. ${ }^{(104,105)}$ Assim, células geneticamente modificadas para expressão de luciferase podem ser rastreadas após a injeção de luciferina utilizando câmeras com dispositivo acoplado a carga altamente sensível para detectar luz. ${ }^{(106)}$

Podemos observar na tabela 1 que a imagem de BLM tem baixa resolução espacial (3-5mm), resolução temporal na escala de segundos a minutos, penetração tecidual ocorre entre $1-2 \mathrm{~cm}$ e sensibilidade na faixa de $10^{-15}-10^{-17} \mathrm{~mol} / \mathrm{L}$. Portanto, esta técnica permite a avaliação das células após transplante por longos períodos, sendo uma análise de baixo custo, que não requer a exposição à radiação, como as técnicas de imagem nuclear. As desvantagens do uso da BLM estão na atenuação da sensibilidade por tecidos sobrepostos e a baixa profundidade de penetração. Sua principal limitação é que está restrita a estudos pré-clínicos, não sendo aplicada em estudos clínicos. 


\subsubsection{Imagem de fluorescência}

A imagem de FL no espectro infravermelho é outra modalidade de imagem ótica, diferentemente da imagem de BLM que depende de uma enzima reagindo com seu substrato para geração de luz, a imagem de FL ocorre por um processo físico, no qual um elétron é excitado e seu retorno a posição inicial faz com que seja gerada luz (Figura 12). ${ }^{(107)}$

Geralmente o uso de agentes fluorescentes para o rastreamento de células in vivo requer procedimentos invasivos, já que a imagem de FL possui penetração limitada em tecidos, um exemplo é a microscopia intravital que permite a visualização das células marcadas por meio da abertura de uma janela no local onde se pretende analisar, ${ }^{(108)}$ outra estratégia utilizada é o uso de modelos geneticamente modificados que sejam transparentes e permitam a visualização por microscopia ótica das células transplantadas. ${ }^{(109,110)}$ Considerando esse panorama, a marcação com agentes fluorescentes no infravermelho próximo (NIRF - near-infrared fluorescence), que tem um espectro de emissão de luz na faixa de 700 a 900nm, torna viável o rastreamento in vivo não invasivo das CTH. Na faixa de emissão do NIRF, sinais interferentes como oxi e desoxi hemoglobina e água são mais baixos e os fótons podem penetrar mais profundamente nos tecidos vivos, quando comparado aos agentes de FL que emitem luz em comprimentos de onda menores como: GFP (505nm), TRITC (572nm) e DsRed (586nm). ${ }^{(111)}$

A imagem de NIRF, como podemos observar na tabela 1 possui baixa resolução espacial $(2-3 \mathrm{~mm})$, a resolução temporal está na escala de segundos a minutos, penetração tecidual é menor que $1 \mathrm{~cm}$ e sua sensibilidade na faixa de $10^{-9}-10^{-}$ $12 \mathrm{~mol} / \mathrm{L}$. As vantagens desta técnica estão no uso de vários agentes fluorescentes simultaneamente, alta sensibilidade, baixo custo, além de não ter a necessidade de exposição à radiação, como as técnicas de imagem nuclear. As desvantagens do uso da imagem de FL estão na atenuação da sensibilidade por tecidos sobrepostos, baixa profundidade de penetração e autofluorescência. Assim como a imagem de BLM, a FL também está restrita a estudos pré-clínicos, devido ao uso de células geneticamente modificadas.

Portanto, a avaliação da expressão de BLM por células modificadas já é uma importante ferramenta para o monitoramento celular in vivo, entretanto, se 
houver morte celular precoce, não será possível determinar a sua localização já que a BLM depende da viabilidade celular. Neste caso, a marcação celular com NPMM seria uma estratégia adicional que possibilita a localização celular, mesmo que estas células não estejam mais viáveis.

Considerando este panorama, a execução do presente trabalho visa mapear e avaliar o potencial de enxertia de CTH de MO de camundongos jovens e idosos, marcadas com NPMM e aplicadas ao modelo de TMO. Para tanto, serão utilizados recursos nanobiotecnológicos para monitorar as CTH por técnicas de FL e BLM com dados corroborados por técnicas histológicas.

\subsection{Objetivos}

1. Avaliar o homing de células-tronco hematopoiéticas provenientes de camundongos jovens e idosos, marcadas com nanopartículas superparamagnéticas de óxido de ferro e modificadas para expressão de luciferase, por técnicas de imagem molecular em modelo de transplante de medula óssea;

2. Realizar uma revisão sistemática da literatura sobre técnicas não invasivas para rastreamento de células-tronco hematopoiéticas em modelo de transplante de medula óssea;

3. Realizar a caracterização físico-química das nanopartículas multimodais;

4. Realizar a transdução das células medulares de animais jovens e idosos com gene repórter de luciferase e avaliar a cinética por imagem de bioluminescência;

5. Avaliar in vitro a internalização nas células medulares das nanopartículas multimodais;

6. Avaliar a sensibilidade e quantificar a marcação das células medulares com nanopartículas multimodais, além de verificar a viabilidade das células após marcação;

7. Avaliar in vivo a migração das células medulares transduzidas e marcadas com nanopartículas multimodais por imagem de bioluminescência, fluorescência no infravermelho próximo e análise histológica. 


\section{MÉTODOS}

Para a realização do trabalho foi aplicada a metodologia descrita no presente capítulo e resumida na figura 14, sendo que foi dividida em quatro etapas: na $1^{\text {a }}$ etapa foi realizada a revisão sistemática da literatura para o entendimento sobre as melhores estratégias para realizar o rastreamento in vivo de $\mathrm{CTH}$ de forma não invasiva. A $2^{\underline{a}}$ etapa corresponde à caraterização físico-química das NPMM; na $3^{\underline{a}}$ etapa a realização do estudo in vitro com células isoladas a partir de camundongos jovens e idosos, com a transdução de luciferase seguido pela cinética de BLM, então a marcação das células com NPMM, seguida da avaliação do processo de internalização, bem como a viabilidade após marcação, a intensidade do sinal pela técnica de NIRF e quantificação da carga de ferro internalizada por NIRF, espectrometria de massa e IRM. Finalmente, a 4⿳a etapa corresponde ao estudo in vivo do modelo de transplante com rastreamento in vivo das células nos animais por imagem de BLM e NIRF.

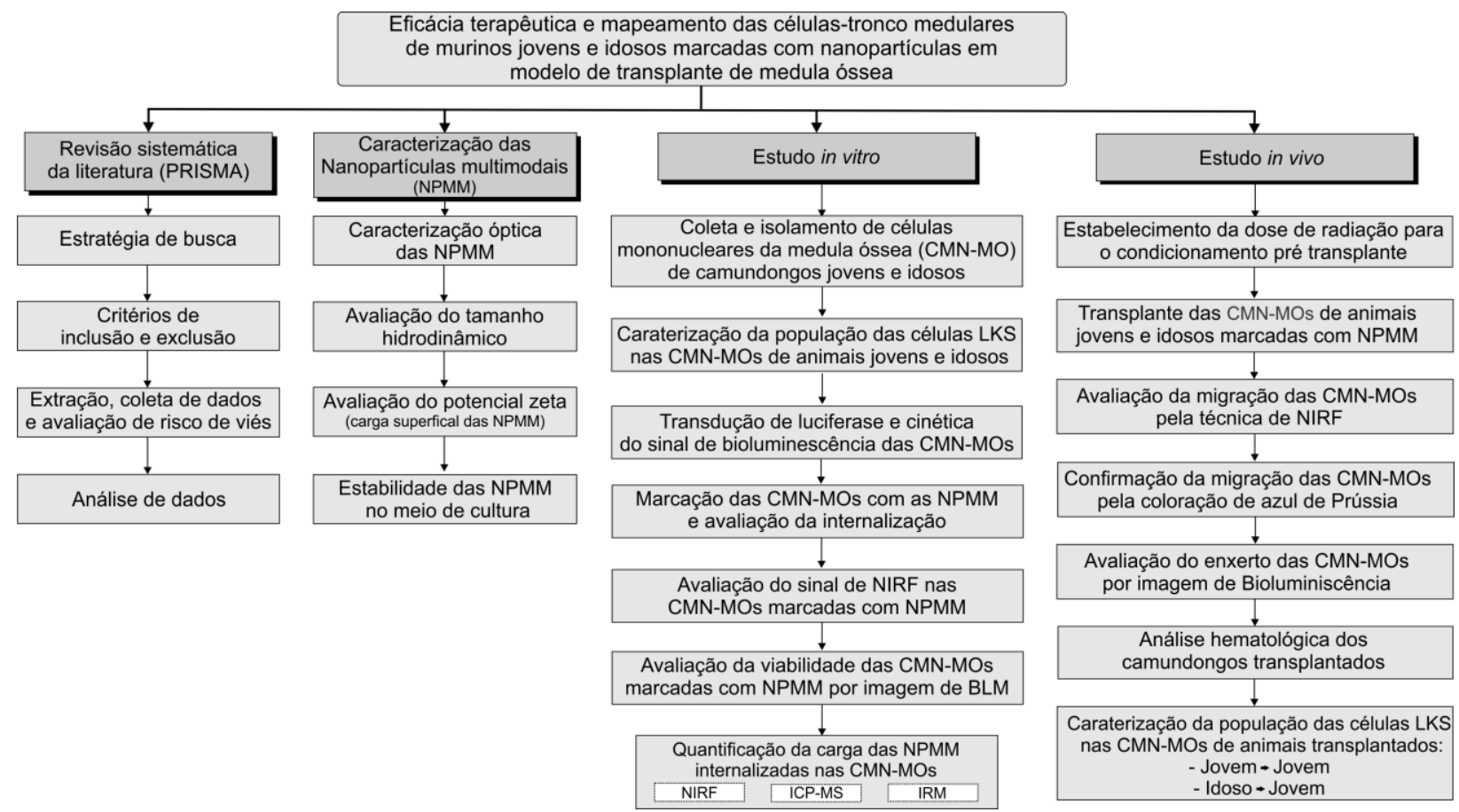

PRISMA: principais itens para relatar revisões sistemáticas e meta-análises; NPMM: nanopartículas multimodais; CMN-MO: célula mononuclear da medula óssea; BLM: bioluminescência; NIRF: fluorescência no infravermelho próximo; ICP-MS: espectrometria de massa por plasma indutivamente acoplado; IRM: imagem de ressonância magnética.

Figura 14. Desenho experimental do estudo dividido em quatro etapas 


\subsection{Revisão sistemática}

Considerando a importância de obter dados da literatura de todos os trabalhos científicos publicados nos principais bancos de dados com objetivos semelhantes ao do presente trabalho foi realizada uma revisão sistemática de artigos originais publicados entre os anos de 2000 e 2020, seguindo as diretrizes dos principais itens para relatar revisões sistemáticas e meta-análises (PRISMA - Preferred Reporting Items for Systematic Reviews and Meta-Analyses). ${ }^{(112)}$

\subsubsection{Estratégia de busca}

Foram pesquisados artigos indexados, publicados antes de janeiro de 2020, nas bases de dados PubMed, Cochrane Library e Scopus, utilizando os seguintes critérios de interesse selecionados em inglês:

((Hematopoietic Stem Cell OR Hematopoietic Progenitor Cell) AND (Tracking OR Homing) AND (Transplantation))

Scopus:

((TITLE-ABS-KEY (tracking) OR TITLE-ABS-KEY (homing))) AND ((TITLE-ABS-KEY ("Hematopoietic Stem Cell") OR TITLE-ABS-KEY ("Hematopoietic Stem Cells") OR TITLE-ABS-KEY ("Hematopoietic Cell") OR TITLE-ABS-KEY ("Hematopoietic Cells") OR TITLE-ABS-KEY ("Hematopoietic Progenitor Cell") OR TITLE-ABS-KEY ("Hematopoietic Progenitor Cells"))) AND (TITLE-ABS-KEY (transplantation))

PubMed:

((((("Hematopoietic Stem Cell"[Title/Abstract]) OR "Hematopoietic Stem Cells"[Title/Abstract]) OR "Hematopoietic Progenitor Cell"[Title/Abstract]) OR "Hematopoietic Progenitor Cells"[Title/Abstract])) AND ((tracking[Title/Abstract]) OR homing[Title/Abstract])) AND transplantation[Title/Abstract]

Cochrane:

"hematopoietic stem cell" in Title Abstract Keyword OR "hematopoietic progenitor cell" in Title Abstract Keyword AND tracking in Title Abstract Keyword OR homing in Title Abstract Keyword AND "transplantation" in Title Abstract Keyword 


\subsubsection{Critérios de inclusão e exclusão}

A revisão sistemática incluiu apenas artigos originais escritos em inglês, publicados entre 2000 e 2020, que usaram:

I. Modelos in vivo de TMO;

II. Agentes de rastreamento para rastrear as $\mathrm{CTH}$ marcadas com esses agentes;

III. Técnicas não invasivas para permitir o rastreamento in vivo de CTH no modelo de TMO.

Os critérios para exclusão foram:

I. Revisões;

II. Artigos clínicos;

III. Capítulos de livros;

IV. Protocolos;

V. Editoriais ou opiniões de especialistas;

VI. Cartas ou artigos de comunicação rápida;

VII. Publicações em outros idiomas que não o inglês;

VIII. Artigos que não analisaram o homing das CTH com técnicas não invasivas;

IX. Artigos indexados publicados em mais de um banco de dados (duplicatas);

X. Artigos que utilizaram apenas técnicas invasivas para analisar o homing de $\mathrm{CTH}$.

\subsubsection{Extração e coleta de dados e avaliação de risco de viés}

$\mathrm{Na}$ revisão sistemática, os participantes foram selecionados de forma independente e aleatória (em pares), para revisar e avaliar os títulos e resumos das publicações identificadas pela estratégia de busca nos bancos de dados e todas as publicações potencialmente relevantes foram recuperadas na íntegra. Os revisores avaliaram os artigos em texto completo para decidir se os critérios de elegibilidade foram atendidos. Discrepâncias na seleção do estudo e extração de dados entre os dois revisores foram discutidas com um terceiro revisor e resolvidas. A inclusão final 
dos estudos na revisão sistemática foi de acordo com todos os revisores. Após a inclusão dos estudos os dados foram extraídos e tabelados quanto à fonte e método de isolamento das $\mathrm{CTH}$; marcação das $\mathrm{CTH}$ com agentes de rastreamento; modelo de TMO; rastreamento não invasivo das $\mathrm{CTH}$ por meio de técnicas de imagem molecular.

\subsubsection{Análise de dados da revisão sistemática}

Todos os resultados foram descritos e apresentados utilizando a distribuição percentual para todas as variáveis analisadas nas tabelas.

\subsection{Estudo experimental}

Após a conclusão da revisão sistemática foi realizado o estudo experimental dividido em 3 etapas:

I. Avaliação físico-química das NPMM;

II. Estudo in vitro;

III. Estudo in vivo para avaliação da migração das CTH marcadas com agentes de rastreamento em modelo de TMO, como mostrado na figura 14.

\subsubsection{Avaliação físico-química das nanopartículas multimodais}

\subsubsection{Nanopartículas multimodais de oxido de ferro com dupla fluorescência}

Para realização da marcação das células mononucleares da medula óssea (CMN-MO) foram utilizadas NPMM (BioPal, Worcester, Estados Unidos da América), compostas por um núcleo magnético de magnetita, tamanho hidrodinâmico de $35 \mathrm{~nm}$, núcleo de óxido de ferro de $8 \mathrm{~nm}$ revestido com dextrana, um potencial zeta de $\sim+31 \mathrm{mV}$ e uma densidade de $\sim 1,25 \mathrm{~g} / \mathrm{cm}^{3}$ (Biopal, Molday ION TM), que foram conjugados com fluoróforos que emitem luz em comprimentos de onda de excitação/emissão na faixa de 750/777nm (espectro do infravermelho próximo) e com fluoróforos que emitem luz em comprimentos de onda de excitação/emissão da rodamina-B na faixa de 558/580nm (espectro visível). 


\subsubsection{Propriedades óticas}

A caracterização ótica das NPMM para a corroboração dos parâmetros de excitação/emissão da dupla $\mathrm{FL}$ foi realizada utilizando um espectrofluorofotômetro RF-6000 (Shimadzu, Kyoto, Japão), no qual as medidas foram realizadas com as NPMM dispersas em meio aquoso em uma concentração de $50 \mu \mathrm{g} / \mathrm{mL}$. Os espectros de excitação foram adquiridos na faixa de comprimento de onda de 520 a $800 \mathrm{~nm}$ e emissão de 550 a 780nm. Adicionalmente foram adquiridos os espectros de excitação/emissão em 3D.

\subsubsection{Avaliação do tamanho hidrodinâmico e potencial zeta das nanopartículas multimodais}

A avaliação da polidispersão do tamanho hidrodinâmico das NPMM suspensas em meio aquoso foi realizada no equipamento Zetasizer Ultra (Malvern, Reino Unido) utilizando a técnica de espalhamento de luz dinâmica. A distribuição do tamanho hidrodinâmico foi obtida em ângulo manual de 173ํㅡ média de 20 e tempo de 5 segundos. As medições foram feitas em posição fixa a $25^{\circ} \mathrm{C}$ com período de equilíbrio de 60 segundos.

O diâmetro médio foi obtido ajustando os dados experimentais a uma função de distribuição log-normal:

$$
f\left(D_{N P M M}\right)=\frac{1}{\sqrt{2 \pi} \omega_{N P M M} D_{N P M M}} \exp \left(-\frac{\left(\ln D_{N P M M}-\ln D_{N P M M}^{0}\right)^{2}}{2 \omega_{N P M M}^{2}}\right)
$$

Com diâmetro médio:

$$
<D_{N P M M}>=D_{N P M M}^{0} \exp \left(\omega_{N P M M}^{2} / 2\right)
$$

E desvio padrão do diâmetro médio

$$
\sigma_{N P M M}=D_{P}^{0}\left[\exp \left(2 \omega_{N P M M}^{2}\right)-\exp \left(\omega_{N P M M}^{2}\right)\right]^{1 / 2}
$$


A avaliação do potencial zeta das NPMM também realizada no Zetasizer Ultra em água com $\mathrm{pH}$ de 7,4 na temperatura de $37^{\circ} \mathrm{C}$. Também foi avaliada a influência no tamanho hidrodinâmico do meio de cultura, soro fetal bovino (SFB) e tampão fosfato-salino (PBS - phosphate buffered saline) nas condições mostradas na tabela 2, assim determinamos a influência de cada elemento na marcação celular.

Tabela 2. Amostras para a avaliação da influência do meio sobre o tamanho hidrodinâmico

\begin{tabular}{cccccc}
\hline Condição & NPMM & Água & Meio de cultura & SFB (10\%) & PBS \\
\hline 1 & $\bullet$ & $\bullet$ & & & \\
2 & $\bullet$ & & $\bullet$ & & \\
3 & $\bullet$ & & $\bullet$ & & \\
4 & & & $\bullet$ & & $\bullet$ \\
5 & $\bullet$ & & & & \\
\hline
\end{tabular}

NPMM: nanopartículas multimodais; SFB: soro fetal bovino; PBS: tampão fosfato-salino.

\subsubsection{Avaliação temporal da estabilidade e do tamanho hidrodinâmico das nanopartículas multimodais}

A estabilidade das NPMM suspensas em meio aquoso ao longo do tempo foi avaliada no mesmo equipamento Zetasizer Ultra para observar a manutenção do diâmetro hidrodinâmico nas soluções aquosas onde as NPMM foram dispersas. A análise de estabilidade foi realizada nas condições 1,2 e 3 da tabela 2, utilizando NPMM na concentração de $50 \mu \mathrm{g} / \mathrm{mL}$ a $37^{\circ} \mathrm{C}$ por 420 minutos com registros a cada 30 minutos.

\subsubsection{Estudo in vitro}

Para execução da avalição in vitro foi realizado primeiramente o isolamento das células da MO de camundongos jovens e idosos.

\subsubsection{Uso de animais}

O trabalho foi desenvolvido de acordo com as normas da Comissão de Ética na Utilização de Animais (CEUA) do Hospital Israelita Albert Einstein (HIAE) 
sob o número 3133/17. Foram utilizados camundongos machos e fêmeas da linhagem C57BL/6, pesando entre 20 e $40 \mathrm{~g}$, com idade variando entre 6-8 semanas (animais jovens) à 18 meses (animais idosos). Os animais foram acondicionados no Centro de Experimentação e Treinamento em Cirurgia (CETEC) do Instituto Israelita de Ensino e Pesquisa (IIEP), onde permaneceram alojados com ração e água ad libitum em gaiolas de polipropileno forradas com maravalha autoclavada. O biotério é acreditado pela Association for Assessment and Accreditation of Laboratory Animal Care International (AAALAC), obedecendo a um ciclo claro-escuro de 12 horas (7 às 19 horas), com temperatura ambiente constante de $21 \pm 2^{\circ} \mathrm{C}$, conforme especificações internacionais.

$O$ processo de anestesia para realização de procedimentos invasivos foi realizado por um protocolo pré-estabelecido $(1,0 \mathrm{~mL} / \mathrm{kg}$ de cloridrato de cetamina a $100 \mathrm{mg} / \mathrm{mL}$ e $0,5 \mathrm{~mL} / \mathrm{kg}$ de cloridrato de xilazina a $20 \mathrm{mg} / \mathrm{mL}$ ), as eutanásias para coleta de $\mathrm{MO}$ foram realizadas por overdose anestésica, utilizando 3 vezes a dose anestésica. A indução de anestesia para a avaliação in vivo por imagem de BLM e FL foi realizada com isoflurano utilizando o equipamento de anestesia XGI-8 (Perkin Elmer). Para a indução da anestesia, o animal foi acondicionado em uma caixa de acrílico, acoplada ao sistema de anestesia. Em seguida, foi liberado para a caixa o fluxo de 2,5L/min de $\mathrm{O}_{2}$ com saturação de $2 \%$ de isoflurano para indução da anestesia. Após a indução o animal foi transferido para o interior do equipamento e acoplado a uma cânula de acrílico para manutenção da anestesia com saturação de $2 \%$ de isoflurano.

\subsubsection{Coleta, isolamento e cultura de células mononucleares da medula óssea}

As CMN-MO foram isoladas por gradiente de densidade utilizando Ficoll-Hypaque $(1.070 \mathrm{~g} / \mathrm{mL}$ ) (GE Healthcare). Para isto, 4 dias antes da coleta foi administrado $150 \mathrm{mg} / \mathrm{kg}$ de 5 -fluorouracil (Millipore, Estados Unidos da América) intraperitonealmente nos camundongos C57BL/6 jovens e idosos, com o objetivo de aumentar a população de CTH no pool de CMN-MO. No dia da coleta, os camundongos foram eutanasiados por overdose anestésica, fêmures e tíbias foram extraídos, higienizados com álcool $70 \%$ e centrifugados dentro de ponteiras alocadas em tubos cônicos por 5 minutos a $1000 \mathrm{~g}$ e $21^{\circ} \mathrm{C}$. Após a centrifugação, o pool de células peletizado no fundo dos tubos foi recolhido e ressuspendido em outro tubo 
cônico com 4mL de meio StemSpan Serum-Free Expansion Medium (SFEM; Stem Cell Technologies, Canadá), suplementado com penicilina (100 unidades $/ \mathrm{mL}$ ) e estreptomicina $(100 \mu \mathrm{g} / \mathrm{mL})$ (GIBCO, Invitrogen Technologies, Nova lorque, Estados Unidos da América), interleucina 3 (IL-3) (10ng/mL), interleucina 6 (IL-6) $(10 \mathrm{ng} / \mathrm{mL})$ e SCF (100ng/mL) (PeproTech, Estados Unidos da América). As células foram lavadas e centrifugadas no tubo por 5 minutos a $500 \mathrm{~g}$ e $21^{\circ} \mathrm{C}$, o pellet formado foi novamente ressupendido em $4 \mathrm{~mL}$ de meio SFEM, em outro tubo cônico de $15 \mathrm{~mL}$ foi adicionado $4 \mathrm{~mL}$ de ficoll, e transferiu-se delicadamente o conteúdo do tubo com células para o tubo com ficoll, de modo que os dois não se misturassem, o tubo foi centrifugado por 30 minutos a $400 \mathrm{~g} \mathrm{e} 21^{\circ} \mathrm{C}$, sem freio. Após a centrifugação, o halo formado entre meio de cultura e ficoll foi aspirado, no qual estão localizadas as CMN-MO, as células foram lavadas novamente com o meio, contadas em uma câmara de Neubauer com auxílio do corante celular azul de tripano, após a contagem as células foram distribuídas $1 \times 10^{6}$ células $/ \mathrm{mL}$ em cada poço de uma placa de 24 poços, suspensas com meio SFEM suplementado com citocinas hematopoiéticas e incubadas a $37^{\circ} \mathrm{C}$ com $5 \%$ de $\mathrm{CO}_{2}$. $\mathrm{O}$ processo de isolamento pode ser visualizado na figura 15. 

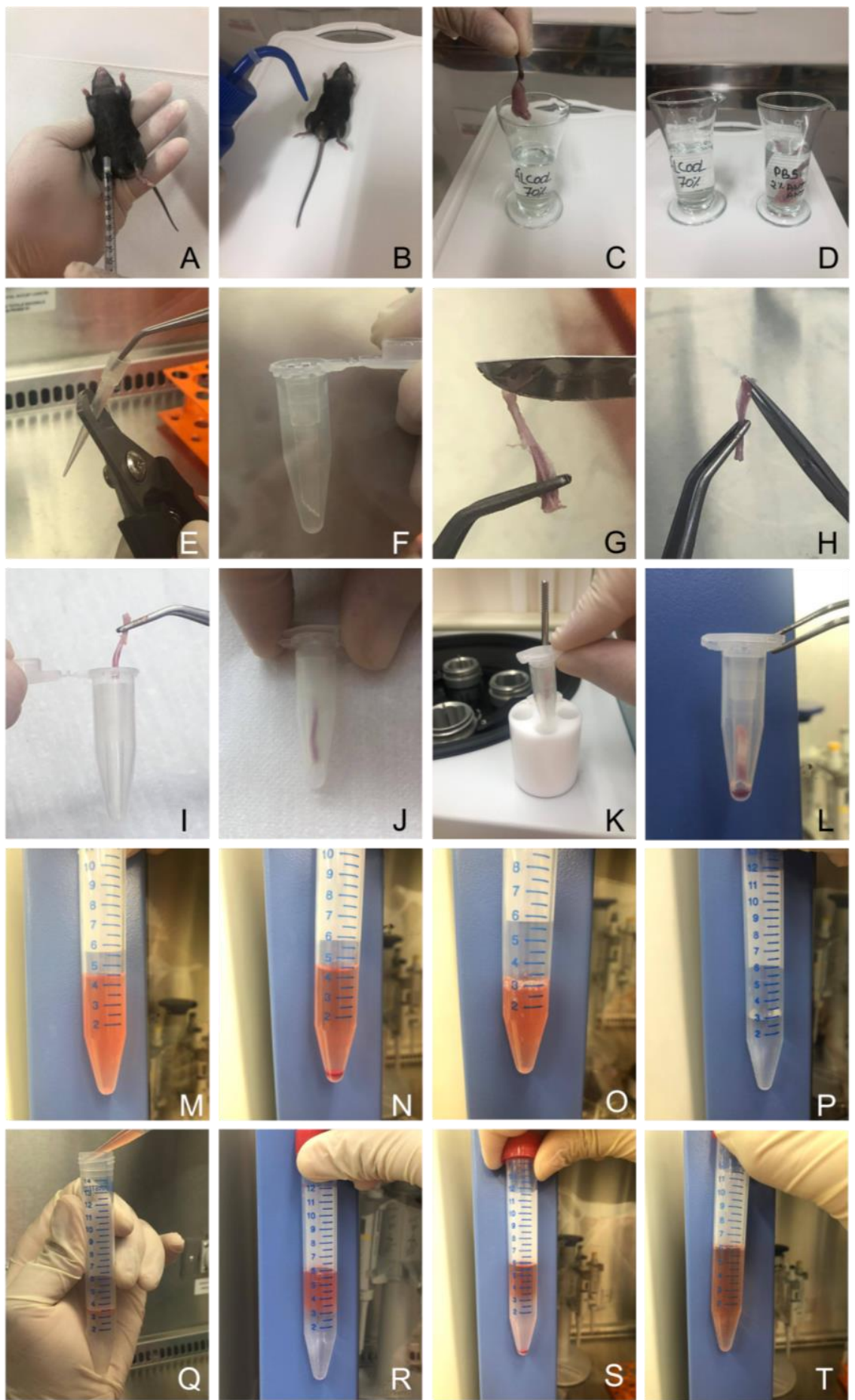

A: Animal eutanasiado por overdose anestésica. B: É realizada a desinfecção dos membros inferiores com álcool 70\%. C-D: Após a extração dos membros inferiores a pele é retirada e os membros inferiores são mergulhados em álcool $70 \%$ e em seguida transferidos para tampão fosfato-salino $2 \%$ antibióticoantimicótico. E-F: Ponteiras de $200 \mu \mathrm{L}$ são cortadas na diagonal e alocadas em eppendorfs de 1,5mL. G: É retirada a musculatura de fêmur e tíbia expondo somente os ossos. H: São retiradas as epífeses ósseas. I-J: O osso é colocado dentro da ponteira localizada no eppendorf. K-L: O eppendorf contendo o osso é centrifugado até formar um pellet com a medula óssea. M-O: O pellet é ressuspendido em meio de cultura e centrifugado para lavagem. P-R: As células em suspensão são transferidas para outro tubo contendo ficoll e então são centrifugadas. S: Após a centrifugação é formado um halo onde estão localizadas as células mononucleares da medula óssea. T: As células contidas no halo são transferidas para outro tubo e centrifugadas para eliminação de resíduos de ficoll, então mais uma vez foram ressuspendidas em meio de cultura para serem cultivadas.

Figura 15. Coleta e isolamento de células mononucleares da medula óssea 


\subsubsection{Caracterização de células linhagem- Sca-1+ c-Kit+ a partir de células mononucleares da medula óssea}

A caracterização das células linhagem- Sca-1+ c-Kit+ (LKS) presentes nas $\mathrm{CMN}-\mathrm{MO}$ isoladas de camundongos C57BL/6 jovens e idosos, foi realizada por citometria de fluxo (FACSAria ${ }^{\mathrm{TM}}$ III, BD Biosciences, Estados Unidos da América). As $\mathrm{CTH}$ foram isoladas utilizando um kit específico para isolamento de $\mathrm{CTH}$ de camundongos (BD Mouse Hematopoietic Stem and Progenitor Cell Isolation Kit, BD Biosciences, Estados Unidos da América) por meio de marcadores imunofenotípicos específicos para isolamento de CTH e células progenitoras hematopoiéticas como Sca1 e CD117 também conhecido como c-Kit e marcadores de linhagens hematopoiéticas como CD3 (marcador de células T), CD45R (marcador de células B), Ly6C e Ly6G (marcadores de granulócitos), CD11b (marcador de macrófagos) e TER-119 (marcador de eritrócitos).

Para a separação das células LKS foram isoladas CMN-MO de camundongos jovens e idosos com e sem a administração prévia de 5-fluorouracil, as células então foram incubadas com os seguintes anticorpos para CTH e para linhagem hematopoiética: PE CD117, PE-Cy7 Sca-1, coquetel de marcadores de células apresentadoras de antígeno (CAA) e 7-amino-actinomicina $D$ (7-AAD), que é um marcador de DNA, utilizado para avaliação da viabilidade celular. As células foram selecionadas primeiramente por viabilidade, em seguida por tamanho e granulosidade, e por último para marcadores de linhagem. Os dados obtidos foram analisados pelos softwares FACSDIVA (BD Biosciences, San Jose, CA) e FlowJo.

\subsubsection{Produção de vírions}

As CMN-MO foram transduzidas com vírions carreando o vetor lentiviral pMSCV.Luc2.T2A_puro. Este vetor codifica a proteína bioluminescente luciferase 2 e a proteína puromicina $\mathrm{N}$-acetil-transferase, a qual confere resistência ao antibiótico puromicina. Para a produção dos vírions, células HEK 293FT foram transfectadas simultaneamente com os vetores pMSCV.Luc2.T2A.puro, pCMV_dr8.91 e pMD2.G. A transfecção foi realizada com politilenimina (PEI) linear de $25 \mathrm{kDa}$ utilizando uma taxa de nitrogênio/f́́sforo de 50. Dois dias após a transfecção, o 
sobrenadante contendo os vírions foi coletado, concentrado por ultracentrifugação e o título viral calculado por reação em cadeia da polimerase PCR - Polymerase chain reaction quantitativo em tempo real.

\subsubsection{Transdução das células mononucleares da medula óssea com vetor luciferase}

Para a transdução lentiviral, após 48 horas da coleta as células de camundongos jovens e idosos foram ressuspendidas em meio SFEM, na presença de IL-3 $10 \mathrm{ng} / \mathrm{mL}$, IL-6 $10 \mathrm{ng} / \mathrm{mL}$ e SCF $100 \mathrm{ng} / \mathrm{mL}$, na densidade de $1 \times 10^{6} / \mathrm{mL}$, foram adicionadas a cultura celular partículas virais em uma multiplicidade de infecção (MOI multiplicity of infection) de 5 na presença de $8 \mu \mathrm{g} / \mathrm{mL}$ de polibreno (Sigma-Aldrich). As células em suspensão foram transferidas para um tubo cônico de $50 \mathrm{~mL}$ e centrifugadas por 90 minutos, a $1000 \mathrm{~g}$ e $33^{\circ} \mathrm{C}$. Após a centrifugação, as células foram transferidas para uma placa de 24 poços e incubadas durante a noite, no dia seguinte foi realizado um novo ciclo de transdução como descrito anteriormente.

\subsubsection{Curva cinética do sinal de bioluminescência das células mononucleares da medula óssea}

A expressão do sinal de BLM nas CMN-MO transduzidas de camundongos jovens e idosos foi realizada nas concentrações celulares por poço de: $2 \times 10^{5}, 1 \times 10^{5}, 5 \times 10^{4}$ e $2,5 \times 10^{4}$ com amostras em quadruplicata sobre uma placa preta de 48 poços, utilizando o equipamento IVIS Lumina LT Série III (Xenogen Corp. CA, Estados Unidos da América). As imagens foram adquiridas após a adição de $20 \mu \mathrm{L}$ de D-luciferina (150mg/mL) (XenoLight, PerkinElmer), e a imagem BLM foi adquirida usando os seguintes parâmetros: tempo de exposição no automático, F/stop 4 e binning 8, com 3 minutos de intervalo entre cada aquisição de imagem, em um total de 297 minutos. A cinética da expressão BLM foi registrada e analisada com o software Living Image versão 4.3.1 (IVIS Imaging System) em unidades de fótons/segundos. 


\subsubsection{Marcação das células mononucleares da medula óssea com nanopartículas multimodais}

Para o processo de marcação das CMN-MO com as NPMM, as células de animais jovens e idosos foram plaqueadas na concentração de $1 \times 10^{6}$ células/mL em uma placa de 24 poços, com meio SFEM suplementado com citocinas hematopoiéticas. Posteriormente, as células foram marcadas com NPMM na concentração de $50 \mu \mathrm{g} / \mathrm{mL}$ por 4 horas a $37^{\circ} \mathrm{C}$. Após esse período, as células foram lavadas três vezes com PBS centrifugando por 5 minutos, a $500 \mathrm{~g}$ e $21^{\circ} \mathrm{C}$, para remover as NPMM que não foram internalizadas.

\subsubsection{Avaliação da internalização das nanopartículas multimodais nas células mononucleares da medula óssea}

A avaliação da internalização das NPMM foi realizada por microscopia de campo claro e FL devido às propriedades óticas (FL no campo claro e no espectro infravermelho) e magnéticas das NPMM.

Para confecção das lâminas as CMN-MO de animais jovens e idosos foram ressuspendidas em PBS, então $10 \mu \mathrm{L}$ foram depositados sobre uma lâmina de vidro. Para a avaliação da internalização pela microscopia de campo claro, foi utilizada a coloração azul da Prússia que evidencia as nanopartículas por corar o ferro presente em azul. Para realização desta coloração foi preparada uma solução contendo ferrocianeto de potássio a 5\% (Sigma Aldrich, St Louis, Estados Unidos da América) e ácido clorídrico a 5\% (Merck, Darmstadt, Alemanha), então foi colocado 10 $\mathrm{LL}$ da solução sobre a lâmina contendo as células por 10 minutos, após este período a lâmina foi lavada em água corrente e em seguida foi realizado a coloração Nuclear Fast Red (Sigma Aldrich St Louis, Estados Unidos da América) por 5 minutos, a lâmina foi lavada mais uma vez em água e analisada por microscopia ótica.

A análise de $F L$ foi realizada após a marcação dos núcleos das CMN-MO por diamidino-2-fenilindol (DAPI, Sigma Aldrich St Louis, Estados Unidos da América) por 5 minutos, seguido de lavagem com água, as imagens de FL foram adquiridas utilizando um filtro de excitação/emissão de 358/461nm para DAPI e de 
530/550nm para as NPMM. Ambas as análises de imagem foram registradas utilizando um microscópio de FL Nikon TiE (Nikon, Tóquio, Japão).

\subsubsection{Avaliação do sinal da fluorescência no infravermelho próximo e viabilidade por bioluminescência após marcação das células mononucleares da medula óssea com nanopartículas multimodais}

Foi realizada a avaliação in vitro do sinal de NIRF nas CMN-MO isoladas de animais jovens e idosos transduzidas com luciferase. Para isso as CMNMO foram marcadas com NPMM nas concentrações de 10, 30 e 50 $\mathrm{g} / \mathrm{mL}$ em uma placa de 24 poços, após 24 horas as células marcadas foram transferidas para eppendorfs e realizadas imagens de $\mathrm{FL}$ do infravermelho próximo no equipamento IVIS, utilizando um tempo de exposição de 2 segundos, F/stop 4, binning 4 e filtro de excitação/emissão de 745nm/ICG.

A viabilidade das CMN-MO marcadas com as NPMM nas concentrações de 10, 30 e $50 \mu \mathrm{g} / \mathrm{mL}$ foram realizadas após a adição de $20 \mu \mathrm{L}$ de luciferina em cada eppendorf e posterior aquisição de imagem de BLM no equipamento IVIS utilizando o tempo de exposição no automático, F/stop 4, binning 8 . Para análise de intensidade da NIRF e BLM foram selecionadas regiões de interesse (ROI - Region of Interest) de $2,5 \mathrm{~cm}^{2}$. Os sinais adquiridos foram analisados no software Living Image em unidades de fótons/s e a viabilidade foi obtida pela relação (Intensidade de BLM das CMN-MO marcadas/Intensidade de BLM das CMN-MO não marcadas) x100.

\subsubsection{Quantificação da carga de nanopartículas internalizada nas células mononucleares da medula óssea}

A avaliação da quantificação de NPMM internalizadas nas CMN-MO após o processo de marcação foi realizada pelas técnicas de NIRF, ICP-MS e IRM.

A) Quantificação pela técnica de FL no infravermelho próximo: A quantificação das NPMM internalizadas nas CMN-MO pela técnica de NIRF foi realizada após a marcação destas células com as concentrações de 10, 30 e $50 \mu \mathrm{g} / \mathrm{mL}$ de NPMM. O sinal NIRF foi detectado após excitação das amostras em 710nm e foi 
registrado na faixa de emissão de 780nm usando o equipamento IVIS. A quantificação absoluta foi determinada após o estabelecimento da curva de calibração, utilizando

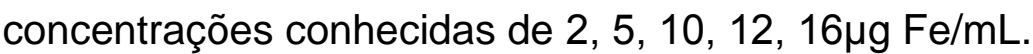

B) Quantificação do ferro internalizado por espectrometria de massa por plasma indutivamente acoplado: A quantificação da carga de ferro internalizada nas CMN-MO após a marcação com NPMM por espectrometria de massa por plasma indutivamente acoplado (ICP-MS - Inductively Coupled Plasma Mass Spectrometry) foi realizada utilizando $1 \times 106$ células $/ \mathrm{mL}$ marcadas com NPMM nas concentrações de 10, 30 e $50 \mu \mathrm{g} / \mathrm{mL}$ dispersas em $1 \mathrm{~mL}$ de PBS e $1 \mathrm{~mL}$ de ácido nítrico (37\%) para digestão durante 4 horas, a $70^{\circ} \mathrm{C}$. As amostras digeridas foram diluídas 10 vezes com água Milli-Q (EMD Millipore Corporation, Bedford MA, Estados Unidos da América) e foram analisadas com o equipamento Nexion 350x ICP-MS (Perkin Elmer Corporation, Estados Unidos da América) para determinar o teor de ferro de cada amostra. As medições da amostra foram realizadas em sextuplicata e a quantificação foi baseada em uma curva de calibração usando ferro padrão certificado (NexION \# N8145054).

C) Quantificação do sinal de ressonância magnética das CMNMO marcadas com NPMM: Para a quantificação das NPMM por IRM as CMN-MO de amimais jovens e idosos foram marcadas com NPMM na concentração de $50 \mu \mathrm{g} / \mathrm{mL}$ e após o período de incubação (4 horas) as células misturadas com agarose a 1\% (Sigma Aldrich, St Louis, MO, Estados Unidos da América) e transferidas para uma placa de poços. As imagens foram adquiridas em um equipamento de tomografia híbrida PET-MRI 3T (Siemens, Alemanha) usando a sequência de imagens ponderadas em T2 (multicontraste turbo-spin eco, SE_MS), com 9 tempos de eco. Seguidamente, as imagens foram analisadas pelo software SyngoVia (Siemens, Alemanha) usando uma ROI para cada poço da IRM para extrair os sinais de intensidade nos diferentes tempos de eco. A partir do ajuste das curvas de decaimento exponencial $I=I_{0} e^{-\left(\frac{T E}{T 2}\right)}$ (onde $I$ é a intensidade do sinal, $I_{0}$ é a intensidade inicial do sinal de ressonância magnética e TE tempo ao eco), foram obtidos os valores do tempo de relaxamento T2. Para o cálculo da quantificação das NPMM ([NPMM]) internalizadas nas células foi utilizado a seguinte relação:

$$
\frac{1}{T_{2}^{\text {CMN-MOSmarcada }}}=\frac{1}{T_{2}^{\text {Controle }}}+r_{2} *[N P M M]
$$


Onde o valor da relaxatividade transversal r2 é de $(19,9 \pm 0,9) \times 10^{-4}$ $\mathrm{ms}^{-1} \mu \mathrm{g} \mathrm{Fe} \mathrm{e}^{-1} \mathrm{~mL}$.

A partir da carga de NPMM [NPMM] que foi internalizado nas células foi calculado o número de NPMM por célula mediante a seguinte relação:

$$
\text { Número de NPMM }=\frac{6 \times[N P M M] \times(\text { massa atômica } F e)}{\pi \times \rho_{N P M M} \times M_{F e} \times \emptyset_{N P M M}},
$$

Onde [NPMM] é a carga de ferro internalizada nas células (grama); $\rho_{N P M M}$ densidade do oxido de ferro; $M_{F e}$ peso molecular do Fe; e $\emptyset_{M-S P I O N}$ diâmetro das NPMM.

\subsubsection{Estudo in vivo}

\subsubsection{Estabelecimento da dose de radiação para condicionamento pré- transplante por irradiação de corpo inteiro}

O condicionamento por $\mathrm{ICI}$ dos animais foi realizado no irradiador de raios-x Rad Source RS2000 do Centro de Medicina Nuclear do Hospital das Clínicas de São Paulo. Os camundongos foram expostos à fonte de raio $\mathrm{X}$ em 4 diferentes doses (5, 7, 9 e 11Gy) (n=3), na taxa de dose de 1Gy/min, estas doses foram aplicadas para realização de uma curva de sobrevida com finalidade de se estabelecer a dose padrão de radiação para o condicionamento dos animais para o TMO.

\subsubsection{Transplante de medula óssea}

O TMO foi realizado em camundongos C57BL/6 de 6-8 semanas de idade. Os camundongos foram irradiados com uma dose de 9Gy, em uma única fração, 24 horas antes do TMO. No momento do TMO, os camundongos foram anestesiados seguindo o protocolo de anestesia previamente descrito, foi realizada a infusão de $1 \times 10^{6}$ CMN-MO marcadas ressuspensas em $150 \mu \mathrm{L}$ de PBS no plexo retro orbital, utilizando uma agulha de $27 \mathrm{G}$, com uma velocidade de infusão de $50 \mu \mathrm{L} / \mathrm{min}$ controlada 
por meio de uma bomba de infusão de microgotas (Pump 11 Elite Nanomite, Massachusetts, Estados Unidos da América).

\subsubsection{Avaliação da migração das células mononucleares da medula óssea}

A Avaliação da migração das CMN-MO foi avaliada pelas técnicas de BLM, NIRF e histologia.

A) Avaliação da migração por imagem de BLM: A obtenção das imagens de BLM das CMN-MO permite avaliar a migração das células após o TMO, além de possibilitar a verificação do enxerto. Com este proposito foram adquiridas imagens de BLM por 4 meses (120 dias), de animais receptores de células jovens $(n=4)$ e idosos $(n=4)$. No primeiro mês as imagens de BLM foram realizadas semanalmente, nos meses seguintes após o transplante as imagens foram adquiridas a cada 15 dias aproximadamente, sendo que 10 minutos antes da aquisição de cada imagem de BLM foi administrada luciferina pela via intraperitoneal. As imagens foram adquiridas no equipamento IVIS nas posições dorsal, ventral, lateral esquerda e direita, utilizando um tempo de exposição automático, $F /$ stop 4 , binning 8 e campo de visão (FOV - field of view) $12,9 \mathrm{~cm}$. Para a aquisição das imagens os animais foram tricotomizados antes da aquisição para reduzir a dispersão dos fótons.

B) Avaliação da migração por imagem de NIRF: A avaliação do homing das CMN-MO por NIRF foi realizada após 4 horas do transplante de células marcadas com NPMM, utilizando as mesmas posições citadas anteriormente e com os seguintes parâmetros: tempo de exposição 3 segundos, F/stop 4, binning8, FOV de $12,9 \mathrm{~cm}$, filtro de excitação 710nm e filtro de emissão 780nm.

C) Avaliação da migração por análise histológica: Após 24 horas da realização do TMO, os animais foram eutanasiados e os tecidos (cérebro, pulmão, coração, fígado, rim, baço e MO) foram coletados e fixados em paraformaldeído 4\% por 24 horas, o tecido ósseo foi descalcificado antes de ser emblocado em parafina, utilizando solução aquosa de ácido etilendinetrilo tetra-acético-sal dissódico dihidratado (EDTA). Após a fixação, os tecidos foram desidratados permanecendo por 1 hora em soluções alcoólicas crescentes, em seguida em soluções de xilol e por fim parafina, como pode ser observado na tabela 3, até o tecido ser incluído em blocos de parafina. Após o processo de inclusão, os tecidos foram cortados na espessura de $5 \mu \mathrm{m}$ em 
micrótomo (Leica) e corados por azul da Prússia e Nuclear fast red. As lâminas foram visualizadas no microscópio de FL Nikon TiE.

Tabela 3. Processo de fixação e inclusão dos tecidos

\begin{tabular}{ccc}
\hline Solução & $\begin{array}{c}\text { Tempo } \\
\text { (horas) }\end{array}$ & $\begin{array}{c}\text { Temperatura } \\
\left({ }^{\circ} \mathbf{C}\right)\end{array}$ \\
\hline Paraformaldeído 4\% & 48 & 21 \\
Etanol $70 \%$ & 1 & 21 \\
Etanol $90 \%$ & 1 & 21 \\
Etanol $100 \%$ & 1 & 21 \\
Etanol 100\% & 1 & 21 \\
Etanol 100\% & 1 & 21 \\
Etanol 100\% & 1 & 21 \\
Xilol & 1 & 21 \\
Xilol & 1 & 21 \\
Xilol & 1 & 21 \\
Parafina & 1 & 55 \\
Parafina & 1 & 55 \\
\hline
\end{tabular}

\subsubsection{Avaliação da reconstituição hematológica por hemograma}

A avaliação do perfil hematológico após (15, 30, 60, 90 e 120 dias) a realização do transplante foi avaliada por hemograma, utilizando amostra de sangue total periférico coletada com a adição de anticoagulante EDTA. A avaliação quantitativa foi realizada utilizando o analisador automático Hematoclin 2.8 Vet (Bioclin).

\subsubsection{Quantificação das células Sca-1+ na medula doadora}

Após 4 meses do TMO de animais jovens e idosos, os animais receptores foram eutanasiados e as CMN-MO coletadas como descrito anteriormente. A quantificação das células LKS presente na MO dos receptores foi realizada por citometria de fluxo utilizando o kit para isolamento de células LKS citado anteriormente. Os dados obtidos foram analisados pelos softwares FACSDIVA e FlowJo. 


\subsection{Análise estatística}

As análises estatísticas foram realizadas utilizando os softwares JASP (0.9.0.1) e Origin 9.1 (OriginLab). Os valores das análises in vitro foram submetidos à avaliação de normalidade pelo teste de igualdade das variâncias (Teste de Levene) para determinar qual teste estatístico utilizar. Foram utilizados os testes de ANOVA e teste $t$ de Student para as análises paramétricas. Dentro do teste de ANOVA foram realizadas análises post hoc para verificar diferenças significativas das variáveis entre cada um dos grupos analisados. Os resultados foram considerados estatisticamente significativos quando apresentaram um valor-p <0,05. 
3 RESULTADOS

\subsection{Revisão sistemática}

\subsubsection{Principais resultados da revisão sistemática}

A revisão sistemática dos artigos originais publicados entre janeiro de 2000 e janeiro de 2020 sobre rastreamento não invasivo de CTH em um modelo de TMO, indexadas no PubMed, Scopus e Cochrane Library, resultou na inclusão de, apenas 21 artigos $^{(56-58,83,104,109,110,113-126)}$ após a aplicação dos critérios de inclusão e exclusão, como também a análise de elegibilidade, como pode ser observado na figura 16.

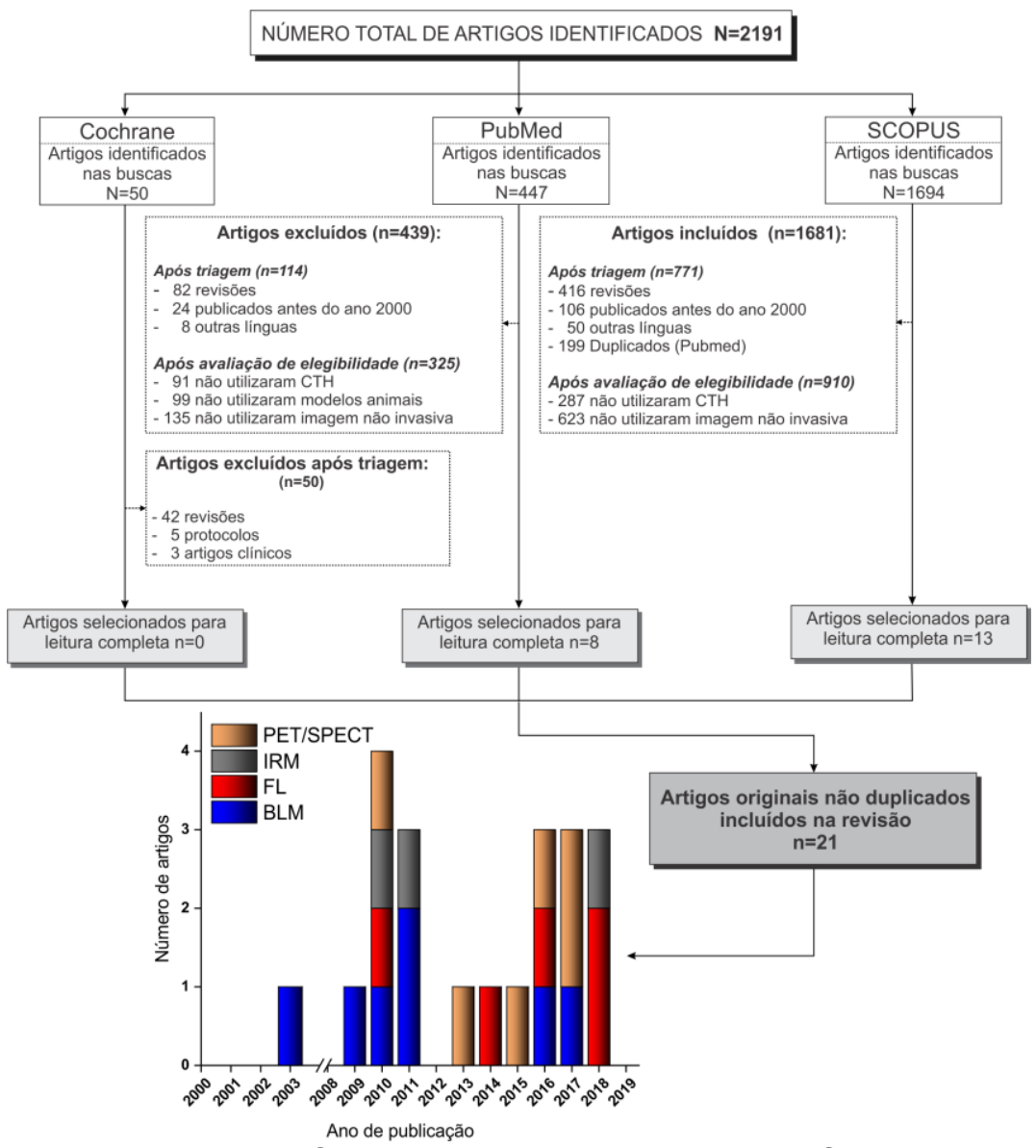

Fonte: Traduzido de Oliveira FA, Nucci MP, Filgueiras IS, Ferreira JM, Nucci LP, Mamani JB, et al. Noninvasive tracking of hematopoietic stem cells in a bone marrow transplant model. Cells. 2020;9(4):939. Figure 1. Flowchart corresponding to the stages of PRISMA guidelines of the article screening process for inclusion in this review. p. $5 .{ }^{(100)}$ Figura 16. Fluxograma baseado nas diretrizes do PRISMA para o processo de seleção de artigos para inclusão na revisão sistemática 
Nesta revisão sistemática dos 21 estudos selecionados foram avaliados principalmente 4 aspectos relacionados a esta temática, Primeiro, quanto a extração e isolamento das células $\mathrm{CTH}$, no qual foi verificado que a maioria dos doadores de $\mathrm{CTH}$ foram os camundongos (43\%), seguido por células de seres humanos (33\%), o nosso estudo experimental também adotou como doadores de CTH os camundongos. Segundo aspecto, a estratégia da marcação das CTH com agentes de rastreamento para avaliação da migração por técnicas de imagem não invasiva, no qual foi realizada principalmente por marcação direta (62\%), sendo $46 \%$ da marcação por radioisótopos para a aquisição de imagens de PET/SPECT, em $31 \%$ as CTH foram marcadas com fluoróforos usados na geração de imagens $\mathrm{FL}$ e em $23 \%$ as células foram marcadas com nanopartículas magnéticas, utilizadas como agente de contraste para realização de IRM. Outros 38\% dos estudos utilizaram marcação indireta, no qual $88 \%$ dos estudos adotados a modificação das células para expressão de luciferase que possibilita a realização de imagens de BLM. No nosso estudo adotamos o uso de NPMM que permitissem a análise das CTH por diferentes técnicas, bem como a utilização da marcação indireta através da transdução das células com luciferase, essa combinação de técnicas permite corroborar a localização das células, já que o uso de somente uma técnica de imagem estaria restrito as limitações intrínsecas da técnica. Terceiro, o TMO foi realizado principalmente em camundongos (57\%) com condicionamento por $\mathrm{ICl}$ em $48 \%$ dos estudos, a análise do enxerto in vitro foi realizada em 18 estudos (86\%), sendo a técnica de citometria de fluxo a mais utilizada. Nosso estudo experimental, também utilizou o condicionamento por $\mathrm{ICI}$ nos camundongos pré-TMO, e análise da enxertia por citometria de fluxo. Quarto aspecto, o rastreamento não invasivo das $\mathrm{CTH}$ foi realizado por imagem de BLM, PET/SPECT, FL e IRM. A BLM não possibilitou avaliação da migração imediata das $\mathrm{CTH}$, em contrapartida permitiu avaliar a longo prazo o enxerto. As imagens de PET/SPECT foram adquiridas após o TMO em até 7 dias. Já a imagem FL na maioria dos casos foi utilizada para avaliação aguda do TMO, somente um estudo realizou a avaliação crônica. A IRM também avaliou a migração após o TMO e um estudo acompanhou as células até 14 dias. Esperamos que ao adotar agentes de contraste multimodais tenhamos a possibilidade do rastreio das $\mathrm{CTH}$ e avaliação da sua enxertia a curto, médio e longo prazo. Os resultados da revisão em texto completo foram publicados na revista Cells. ${ }^{(91)}$ 


\subsection{Estudo experimental}

\subsubsection{Avaliação físico-químicas das nanopartículas multimodais}

\subsubsection{Avaliação do tamanho hidrodinâmico e potencial zeta das nanopartículas multimodais}

A caracterização da distribuição do tamanho das NPMM por meio de espalhamento de luz dinâmico mostrou que após o ajuste com uma distribuição lognormal, o diâmetro hidrodinâmico foi de $(38,2 \pm 0,5 \mathrm{~nm})$ como mostrado na figura 17 . Estes dados foram obtidos com as NPMM suspensas em água.

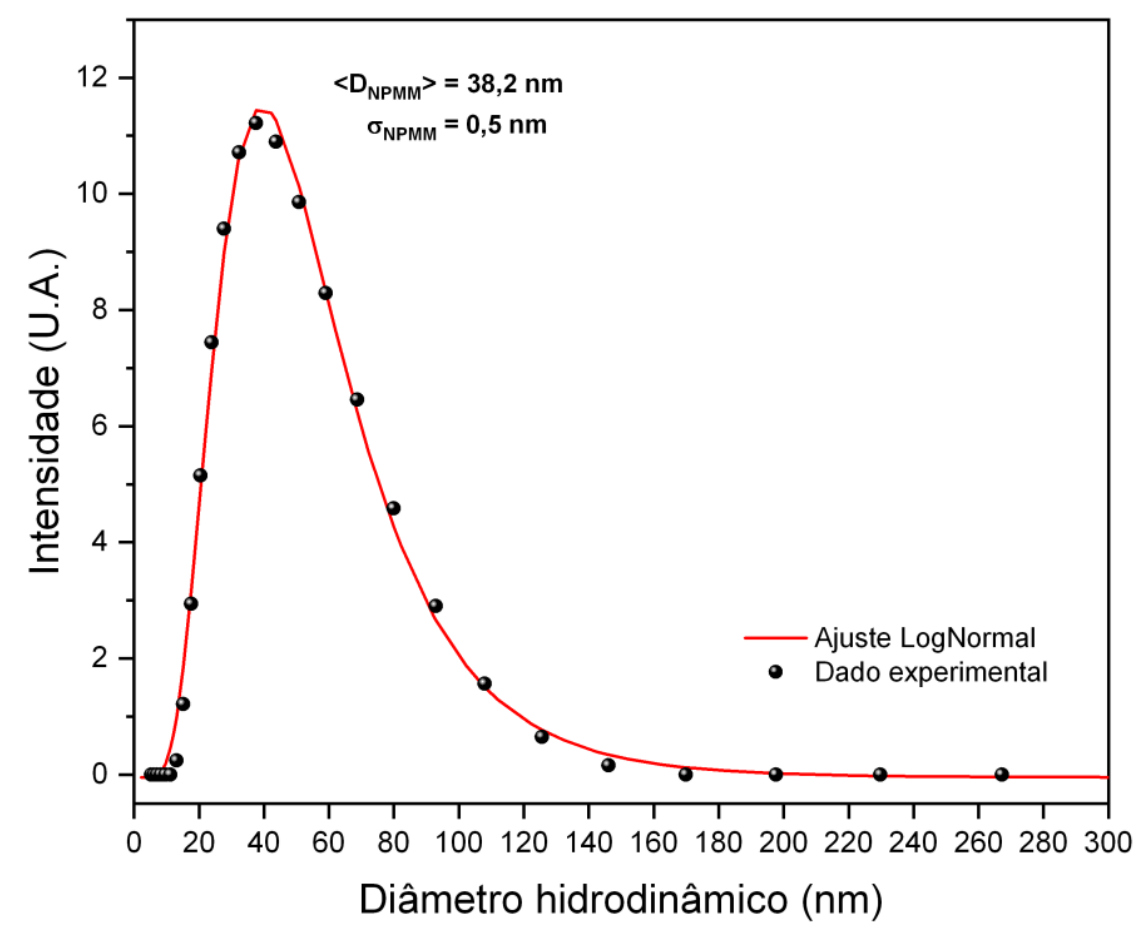

NPMM: nanopartículas multimodais.

Figura 17. Curva de polidispersão do diâmetro hidrodinâmico das nanopartículas multimodais suspensas na água

Para a avaliação da polidispersão as NPMM foram analisadas nas seguintes condições de suspensão: SFEM; água + NPMM; SFEM + NPMM; PBS + NPMM; SFEM + SFB + NPMM; esta avaliação é mostrada na figura 18. Foi observado que a amostra SFEM apresentou um pico em 9,8nm (curva com tracejado em verde). A avaliação de polidispersão da amostra água + NPMM (curva em preto) apresentou um pico de $37,3 \mathrm{~nm}$, mas quando as NPMM foram suspensas no SFEM (SFEM + NPMM) 
foi possível observar dois picos em 9,5nm e 43,6nm (curva em vermelho), que de acordo com os resultados anteriores podemos identificar o pico do SFEM $(9,5 \mathrm{~nm})$ e das NPMM $(43,6 \mathrm{~nm})$, sendo que para este último pico foi possível verificar que ocorreu um aumento do crescimento das NPMM de $37,3 \mathrm{~nm}$ para 43,6nm, entretanto, este novo diâmetro médio não afetaria o processo de internalização pela pouca variabilidade. $\mathrm{Na}$ condição PBS + NPMM (curva em tracejado rosa) foi observado um pico em 32,4nm correspondente ao diâmetro das NPMM sem haver influência do PBS no aumento da mesma. Outra das possiblidades de marcação das células com NPMM é na presença de SFB junto com SFEM e assim foram observados dois picos em $8,3 \mathrm{~nm}$ e $42,7 \mathrm{~nm}$ (curva com tracejado azul), resultado semelhante ao grupo SFEM + NPMM, confirmando assim que o SFB não influência na polidispersão das NPMM. No inset da figura 18 são mostrados três espectros de polidispersão que permitem o entendimento do soluto no processo de marcação celular mostrando que as NPMM não são afetadas pela presença de SFEM e SFB.

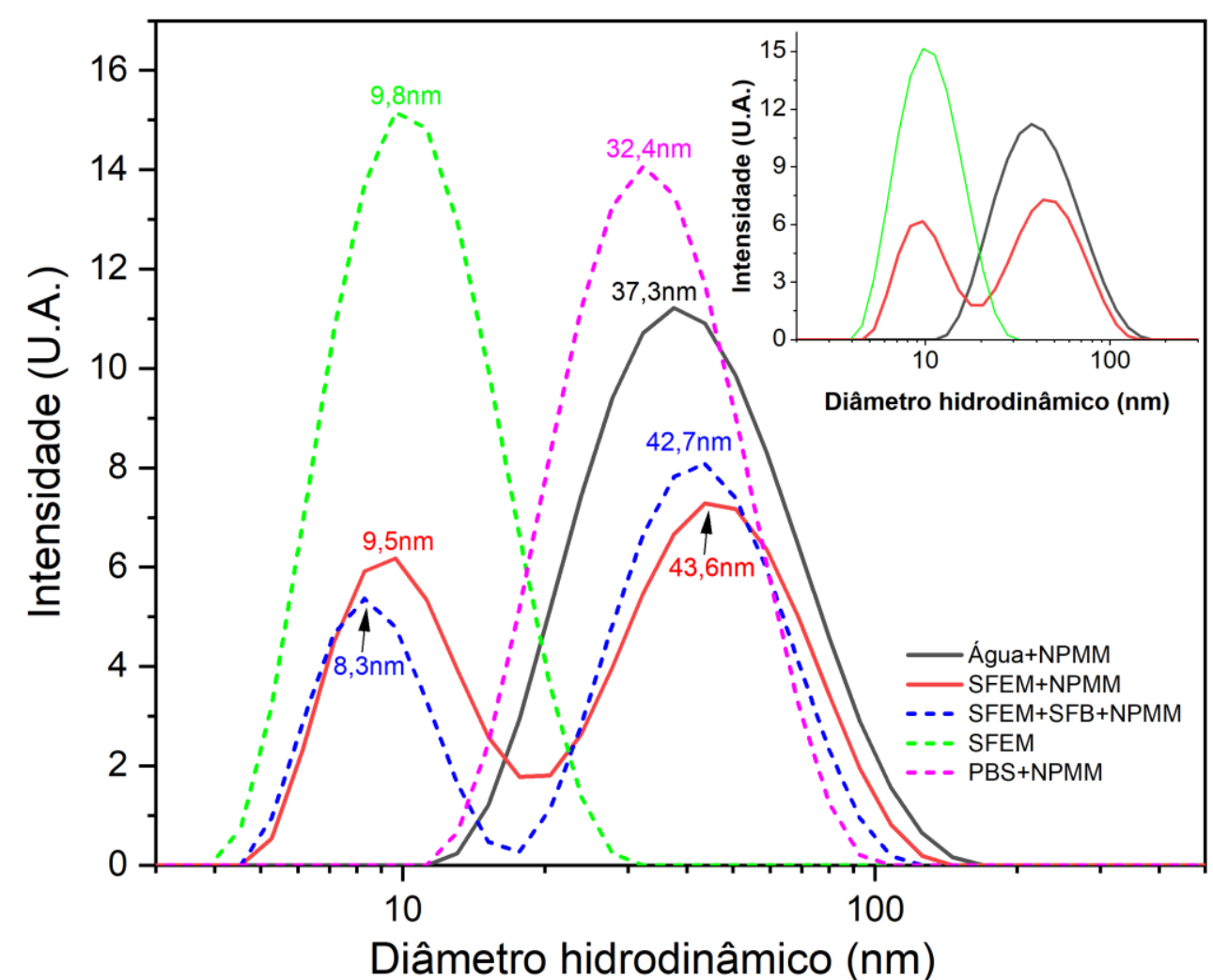

NPMM: nanopartículas multimodais; SFEM: StemSpan Serum-Free Expansion Medium; SFB: soro fetal bovino; PBS: tampão fosfato-salino (phosphate buffered saline).

Figura 18. Curva de polidispersão do diâmetro hidrodinâmico das nanopartículas multimodais em várias condições 
A figura 19 mostra a análise da carga superficial (potencial zeta) das NPMM medida em água com pH de 7,4, o mesmo utilizado na marcação das células com NPMM, sendo encontrado um potencial zeta de aproximadamente $34,9 \mathrm{mV}$. Esse potencial positivo proporciona uma maior interação eletrostática entre as células e as NPMM, favorecendo sua internalização, dado que as células apresentam um potencial zeta negativo e assim ser favorável para uma interação eletrostática.

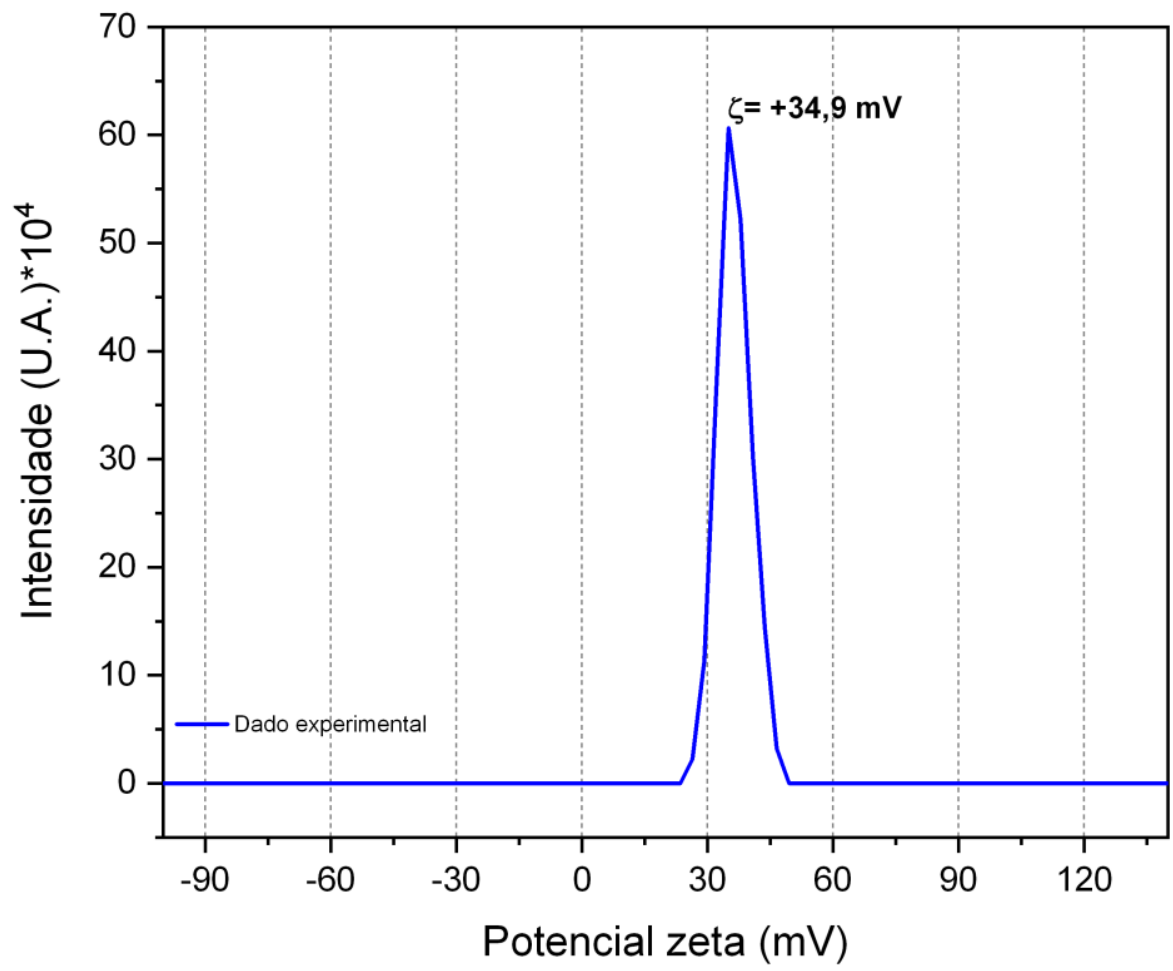

Figura 19. Distribuição do potencial zeta das nanopartículas multimodais com núcleo de óxido de ferro cobertas com dextrana indicando o pico em $34,9 \mathrm{mV}$

\subsubsection{Avaliação da estabilidade do tamanho hidrodinâmico das nanopartículas multimodais temporalmente}

A estabilidade do diâmetro hidrodinâmico das NPMM foi avaliado temporalmente por 420 minutos em diferentes condições (Água + NPMM; SFEM + NPMM; SFEM + SFB + NPMM; respectivamente mostrado no item A, C e D da figura 20) podendo ser observado que as NPMM conseguem manter o diâmetro hidrodinâmico médio ao logo do tempo avaliado sem alterações importantes, como mostrado nos gráficos $B, D$ e $F$ da figura 20 . 

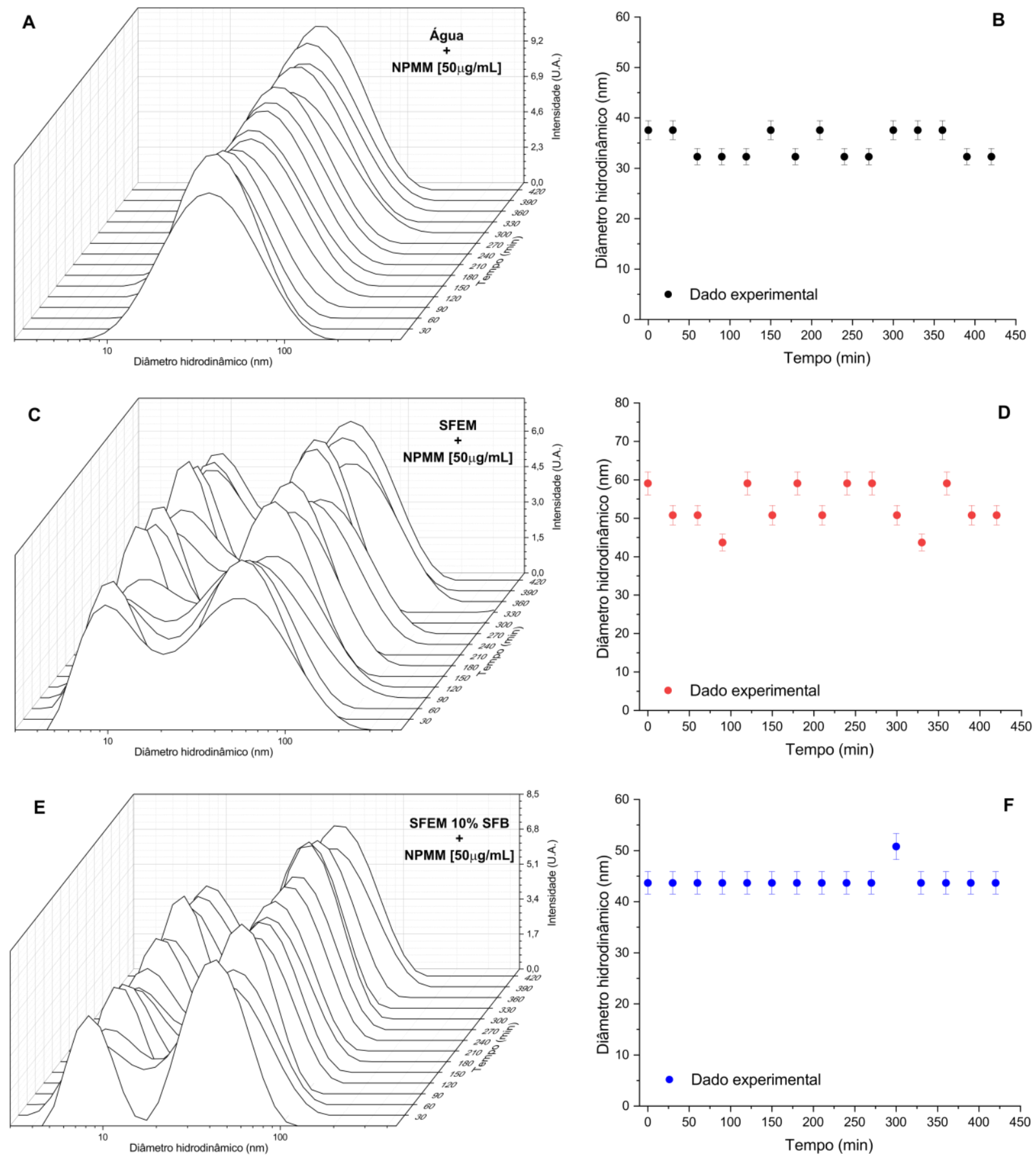

A-B: Análise da estabilidade das nanopartículas multimodais em StemSpan Serum-Free Expansion Medium por 420 minutos. C-D: Análise da estabilidade das nanopartículas multimodais em StemSpan Serum-Free Expansion Medium + soro fetal bovino por 420 minutos. E-F: Análise da estabilidade das nanopartículas multimodais em água por 420 minutos.

Figura 20. Análise da estabilidade das nanopartículas multimodais ao longo do tempo em água, meio de cultura e meio de cultura suplementado com soro fetal bovino 


\subsubsection{Propriedades óticas}

A caracterização ótica das NPMM representada nas figuras 21 e 22 destaca seu espectro de excitação/emissão através de curvas em diferentes cores (vermelho, azul, amarelo e marrom). O espectro da figura 21 mostra o pico de FL no visível $(562,2 / 588,3 \mathrm{~nm})$ e no infravermelho próximo $(757,8 / 779,4 \mathrm{~nm})$. Na figura $22 \mathrm{~A}$ podemos confirmar o espectro evidenciando a dupla FL da nanopartícula, assim como projeções do espectro excitação em 2D nas figuras 22B-C, já a figura 22D permite uma visualização do espectro 3D de excitação/emissão da NPMM com dupla FL confirmando os valores encontrados na figura 21.

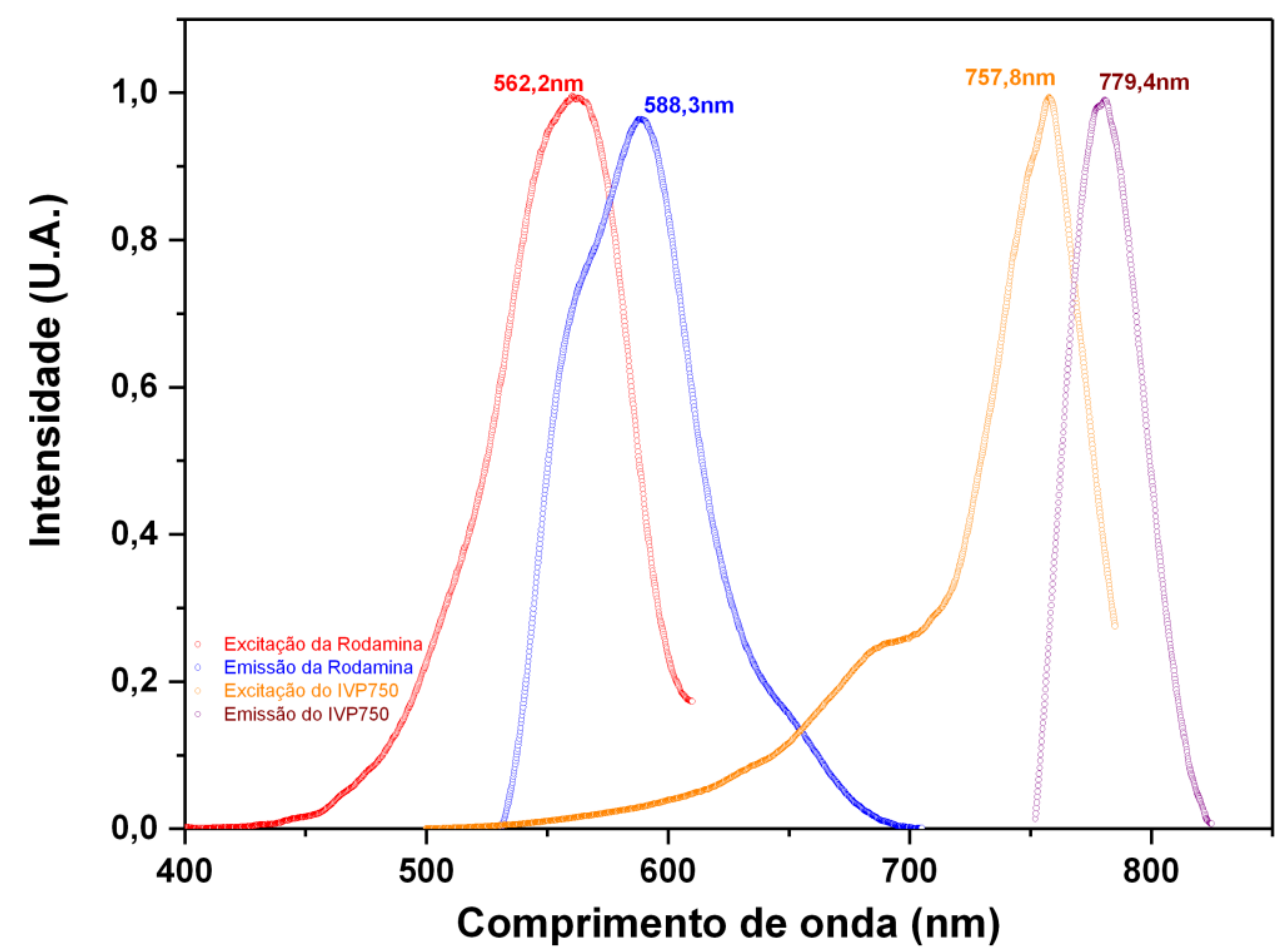

Figura 21. Espectro de excitação/emissão da nanopartícula multimodal evidenciando a dupla fluorescência da nanopartícula 


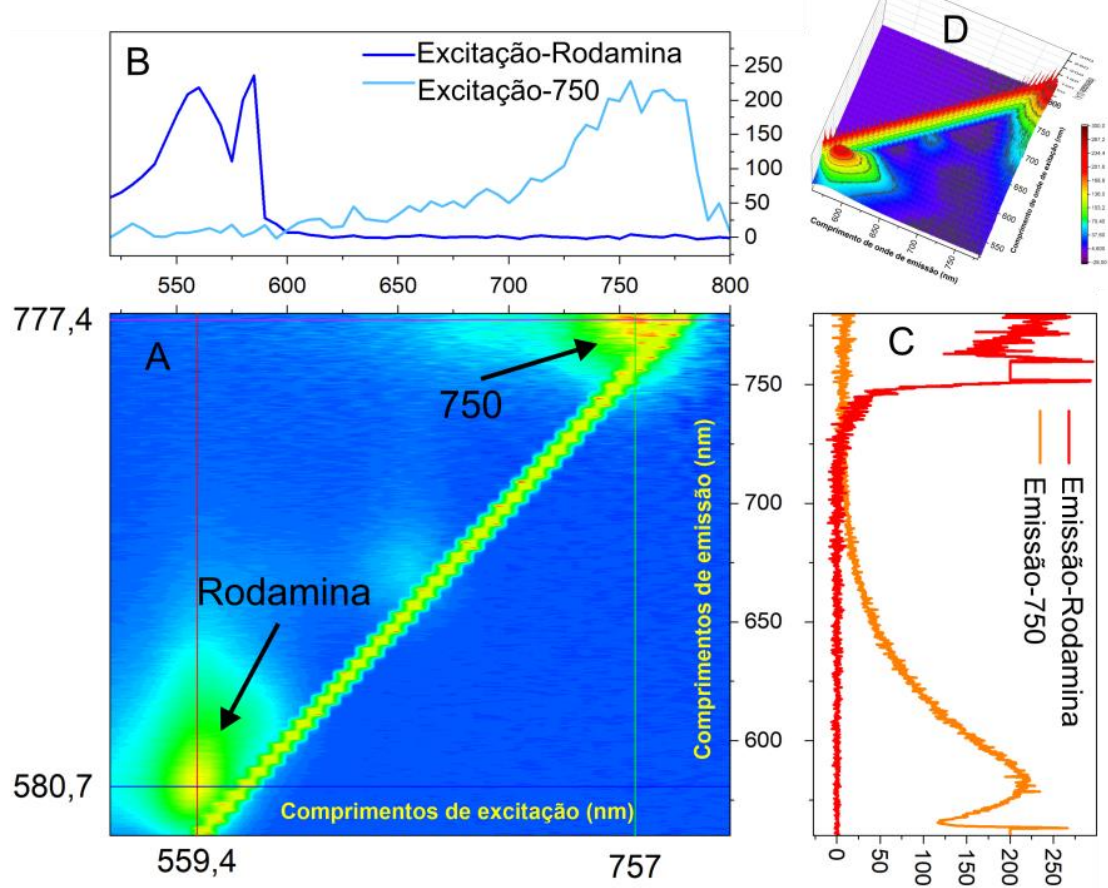

A: Espectro evidenciando a dupla fluorescência da nanopartícula. B: Projeções do espectro excitação em 2D. C: Projeções do espectro emissão em 2D. D: Visualização 3D do excitação/emissão da nanopartícula multimodal com dupla fluorescência.

Figura 22. Espectro 2D e 3D de excitação/emissão da nanopartícula multimodal

\subsection{Estudo in vitro}

\subsubsection{Caracterização de células lin- sca1+ c-kit+ a partir de células mononucleares da medula óssea}

A caracterização de células LSK de animais jovens e idosos foi realizada com e sem a administração prévia de 5-fluorouracil, para avaliar a ação deste antimetabólico antineoplásico sobre a produção de células LKS. A análise por citometria de fluxo (Figura 23) evidenciou que quando não é realizada a administração de 5-fluorouracil a quantidade de CMN-MO isoladas é menor quando comparada as células isoladas de camundongos que receberam 5 -fluorouracil 4 dias antes da coleta. Também foi possível observar um aumento na população de células linhagemindicando uma grande presença de progenitores hematopoiéticos, sendo que as células de camundongos jovens tratados com 5-fluorouracil apresentaram um número maior de células linhagem+ talvez pela capacidade superior de retorno a homeostase quando comparadas a células de animais idosos na mesma condição. 

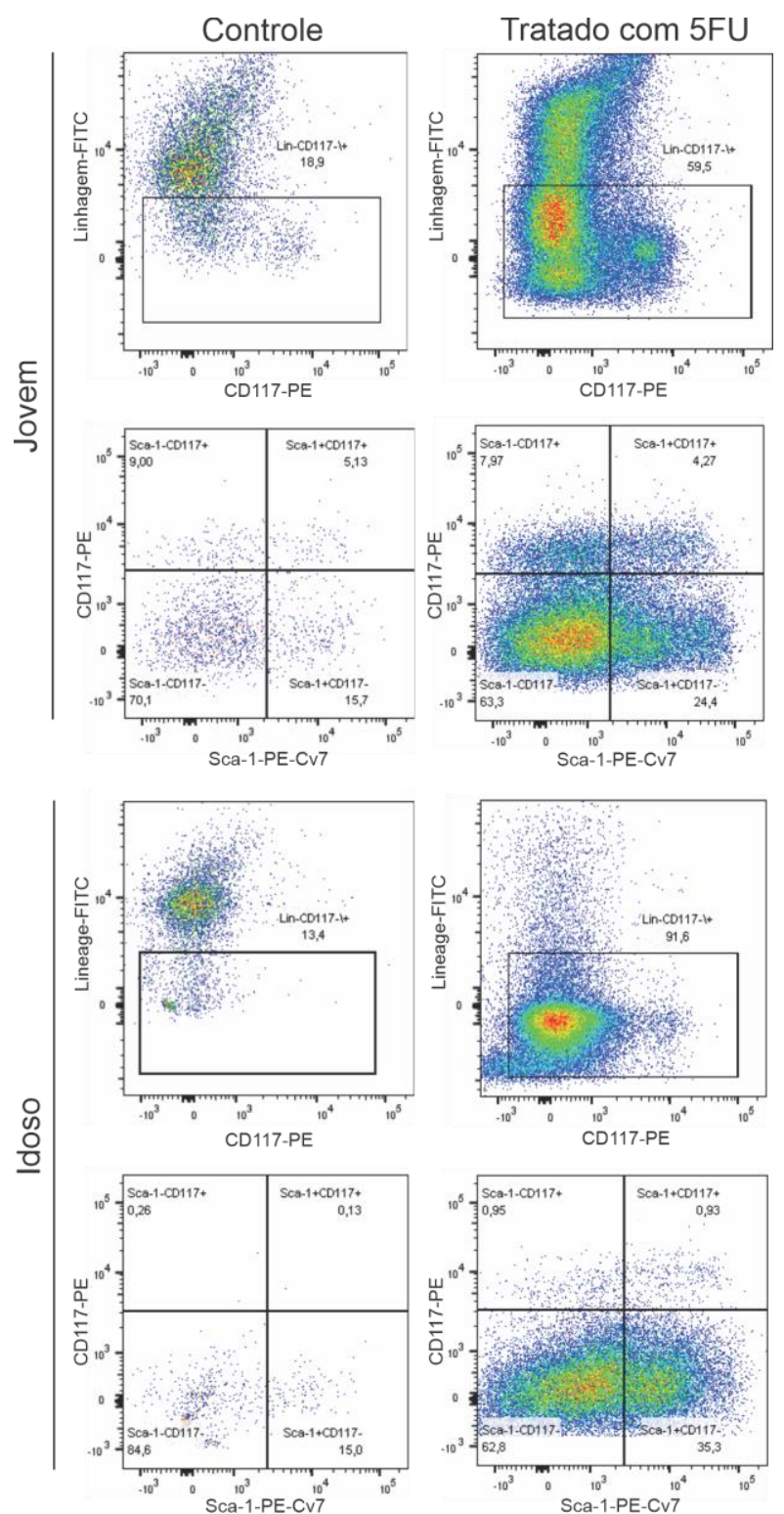

Figura 23. Análise comparativa da população de células linhagem- Sca-1+c-Kit+ de camundongos jovens e idosos com e sem a administração prévia de 5-fluorouracil 4 dias antes da coleta das células

Quando observamos a população de interesse, as células de animais jovens mostraram uma maior frequência que as células de animais idosos, as LKS jovens representaram 5,13\% dos 18,9\% de células linhagem- em animais não tratados, já com a administração prévia de 5-fluorouracil elas representaram 4,27\% dos $59,5 \%$ de células linhagem-, enquanto, as LKS de animais idosos representaram 0,13\% dos $13,4 \%$ de células linhagem- de animais não tratados, já as células de animais idosos tratados com 5-fluorouracil representaram 0,93\% dos 91,65 de células linhagem-. Indicando um aumento na população de células-tronco e progenitores 
hematopoiéticos na população de CMN-MO tanto em animais jovens como em idosos quando é realizada a administração prévia de 5-fluorouracil.

\subsubsection{Avaliação da transdução das células mononucleares da medula óssea de camundongos jovens $e$ idosos com vetor lentiviral por imagem de bioluminescência in vitro}

A avaliação da expressão do sinal de BLM nas CMN-MO isoladas de camundongos jovens e idosos foi realizada durante 297 minutos utilizando diferentes números de células $\left(1 \times 10^{4}, 2 \times 10^{4}, 5 \times 10^{4}, 1 \times 10^{5}\right.$ e $\left.2 \times 10^{5}\right)$. Na figura 24 , pode ser visualizado que o pico de máxima intensidade do sinal de $\operatorname{BLM}\left(9,3 \times 10^{9}\right.$ fótons/s) ocorreu em $2 \times 10^{5}$ células de camundongos jovens, aos 21 minutos, seguido de redução na intensidade do sinal ao longo do tempo.

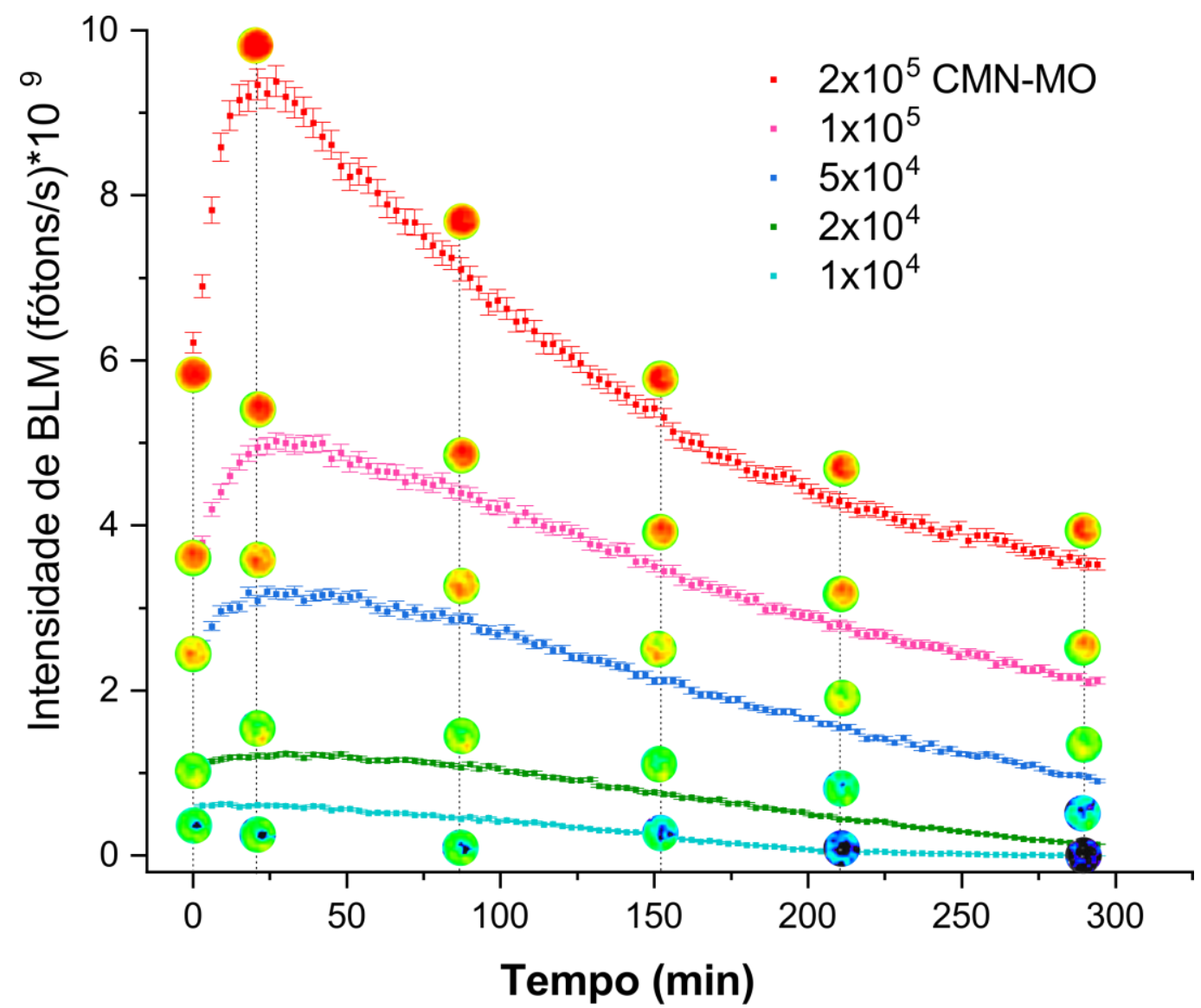

BLM: bioluminescência; CMN-MO: células mononucleares da medula óssea; Min: minutos.

Figura 24. Análise de cinética da intensidade do sinal de bioluminescência de células mononucleares da medula óssea de camundongos jovens em função da concentração celular durante 297 minutos 
Comportamento semelhante foi verificado na figura 25 , onde pico máximo de intensidade do sinal de BLM foi de $8,6 \times 10^{9}$ fótons/s na amostra de $2 \times 10^{5}$ células de camundongos idosos sendo obtido em cerca de 21 minutos, com uma redução do sinal ao longo do tempo. Esse padrão de decaimento do sinal pode ser visualizado nos outros números de CMN-MO avaliados: $1 \times 10^{5}, 5 \times 10^{4}, 2 \times 10^{4}$ e $1 \times 10^{4}$ após seus correspondentes picos de intensidade máxima para jovens: $5 \times 10^{9}, 3,3 \times 10^{9}$, $1,3 \times 10^{9}, 7 \times 10^{8}$ fótons/s e para idosos: $5 \times 10^{9}, 3 \times 10^{9}, 1,4 \times 10^{9}$ e $5 \times 10^{8}$ fótons/s respectivamente.

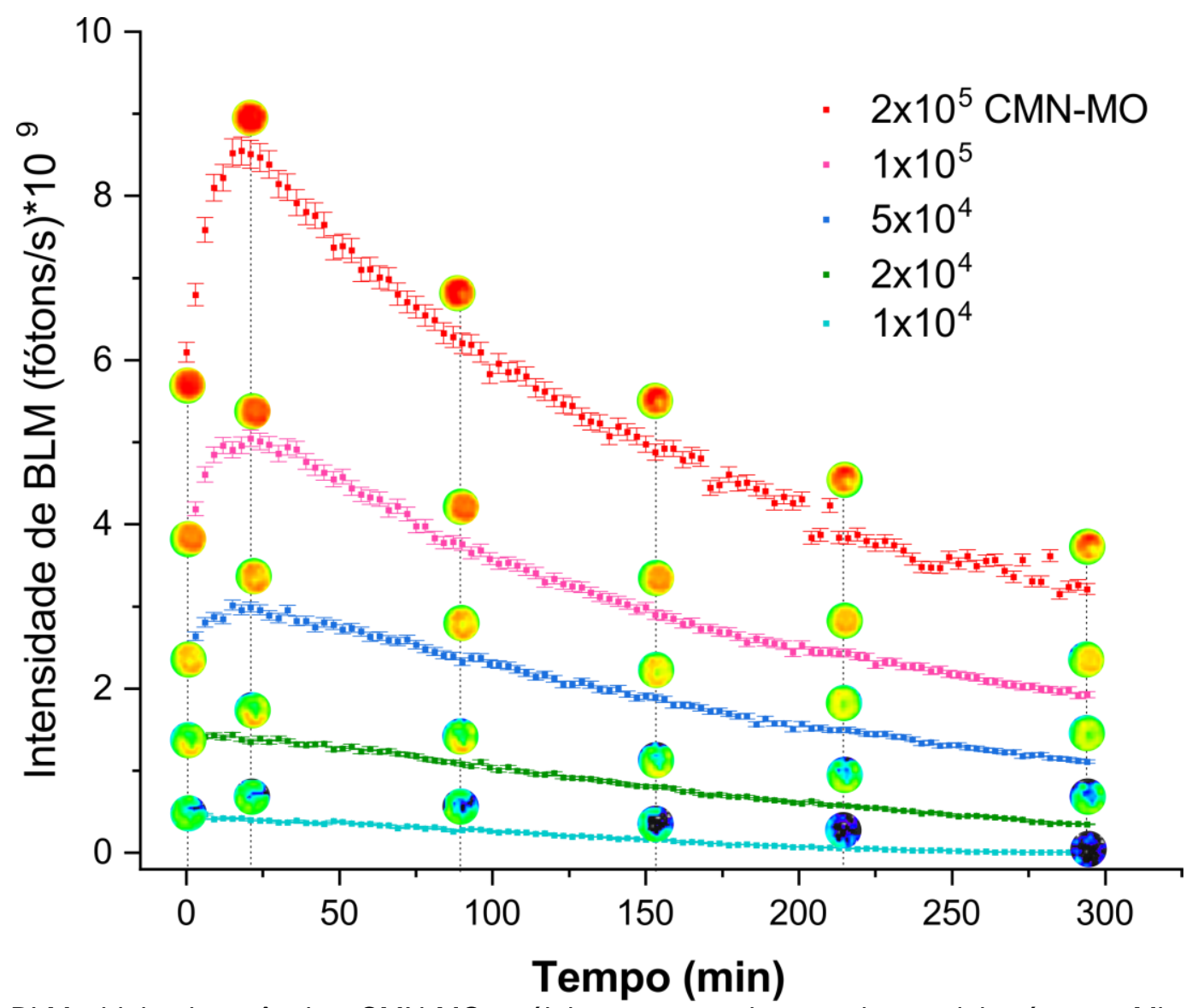

BLM: bioluminescência; CMN-MO: células mononucleares da medula óssea; Min: minutos.

Figura 25. Análise de cinética da intensidade do sinal de bioluminescência de células mononucleares da medula óssea de camundongos idosos em função da concentração celular durante 297 minutos

Foi realizada a comparação das intensidades de BLM entre as diferentes concentrações de células dos camundongos jovens e idosos através de uma curva de intensidade utilizando os maiores picos de sinal de cada concentração de células utilizado, tanto para camundongos jovens como para idosos, onde se observou um comportamento exponencial nas CMN-MO de camundongos jovens e idosos após 
ajuste como pode ser observado na figura 26 , onde não foi possível observa diferença na intensidade de BLM entre os grupos das células dos camundongos jovens e idosos.

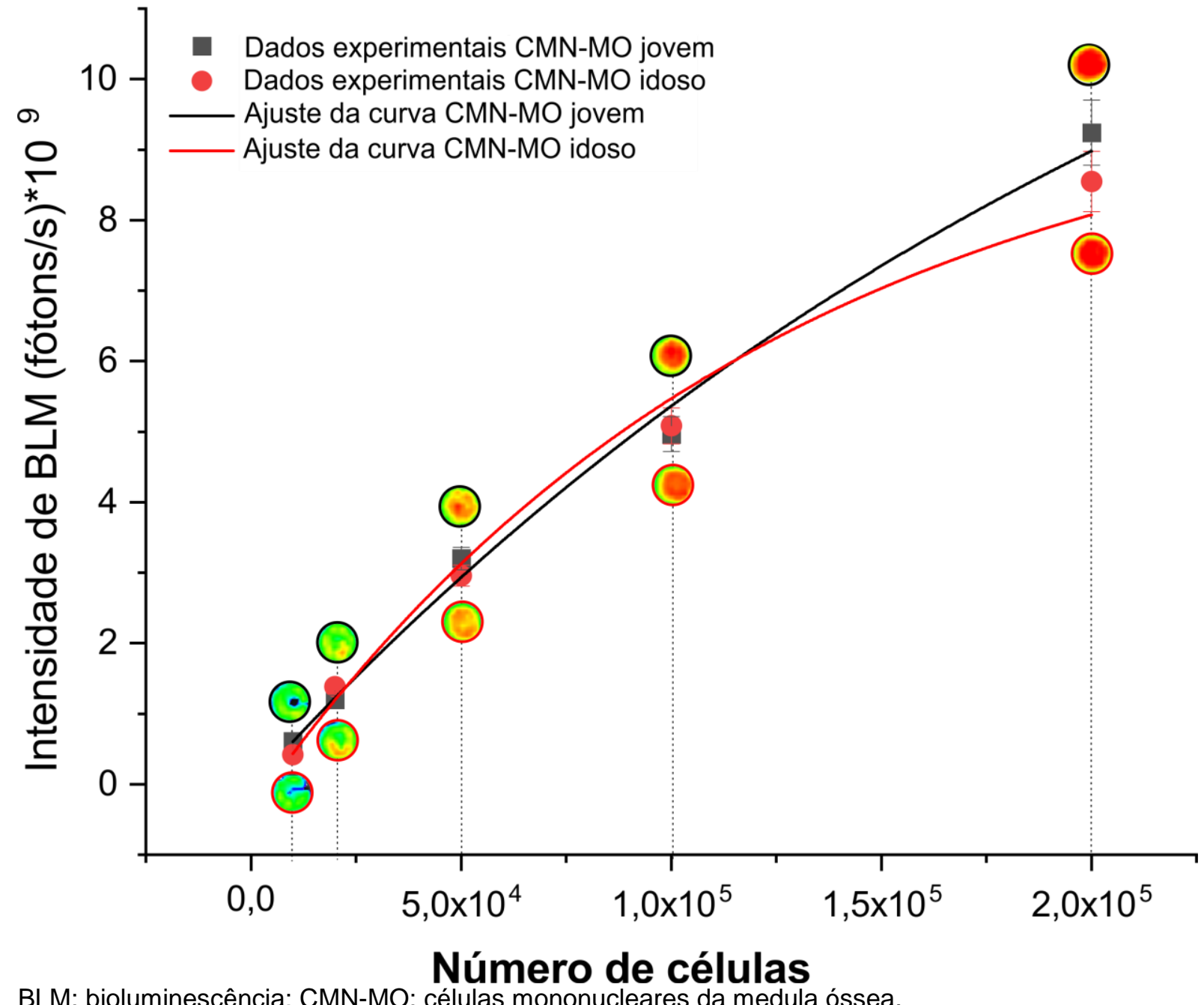

Figura 26. Curva de correlação da cinética de bioluminescência entre camundongos jovens e idosos após ajuste

\subsubsection{Avaliação da marcação das células mononucleares da medula óssea de camundongos jovens e idosos com nanopartículas multimodais}

Após o processo de marcação das CMN-MO isoladas de camundongos jovens e idosos com NPMM, foi verificada a internalização das NPMM por microscopia de campo claro e FL no espectro visível. A figura 27A mostra a marcação de CMN-MO isoladas de camundongos jovens e marcadas com NPMM por microscopia de campo claro e FL. Já a figura 27B mostra a marcação de CMN-MO isoladas de camundongos idosos e marcadas com NPMM por microscopia de campo 
claro e FL. Ambas as imagens foram realizadas em três diferentes aumentos (10x, 40x e 100x), sendo que em cada FOV foram realizadas imagens correspondentes em campo claro e FL no mesmo aumento. A microscopia de campo claro permitiu visualizar as CMN-MO destacando o ferro intracelular das NPMM internalizadas no citoplasma das células, por meio da coloração de azul da Prússia. A microscopia de FL permitiu visualizar a presença do fluoróforo de rodamina-B acoplado a NPMM através da imagem em vermelho e pela marcação dos núcleos das CMN-MO por DAPI que é visualizado em azul. A análise por microscopia em campo claro e FL permitiu visualizar a capacidade de internalização das NPMM tanto em CMN-MO de camundongos jovens quanto em camundongos idosos.

A $\quad$ стH-C57BL6 jovem marcado com NPMM B CTH-C57BL/6 idoso marcado com NPMM
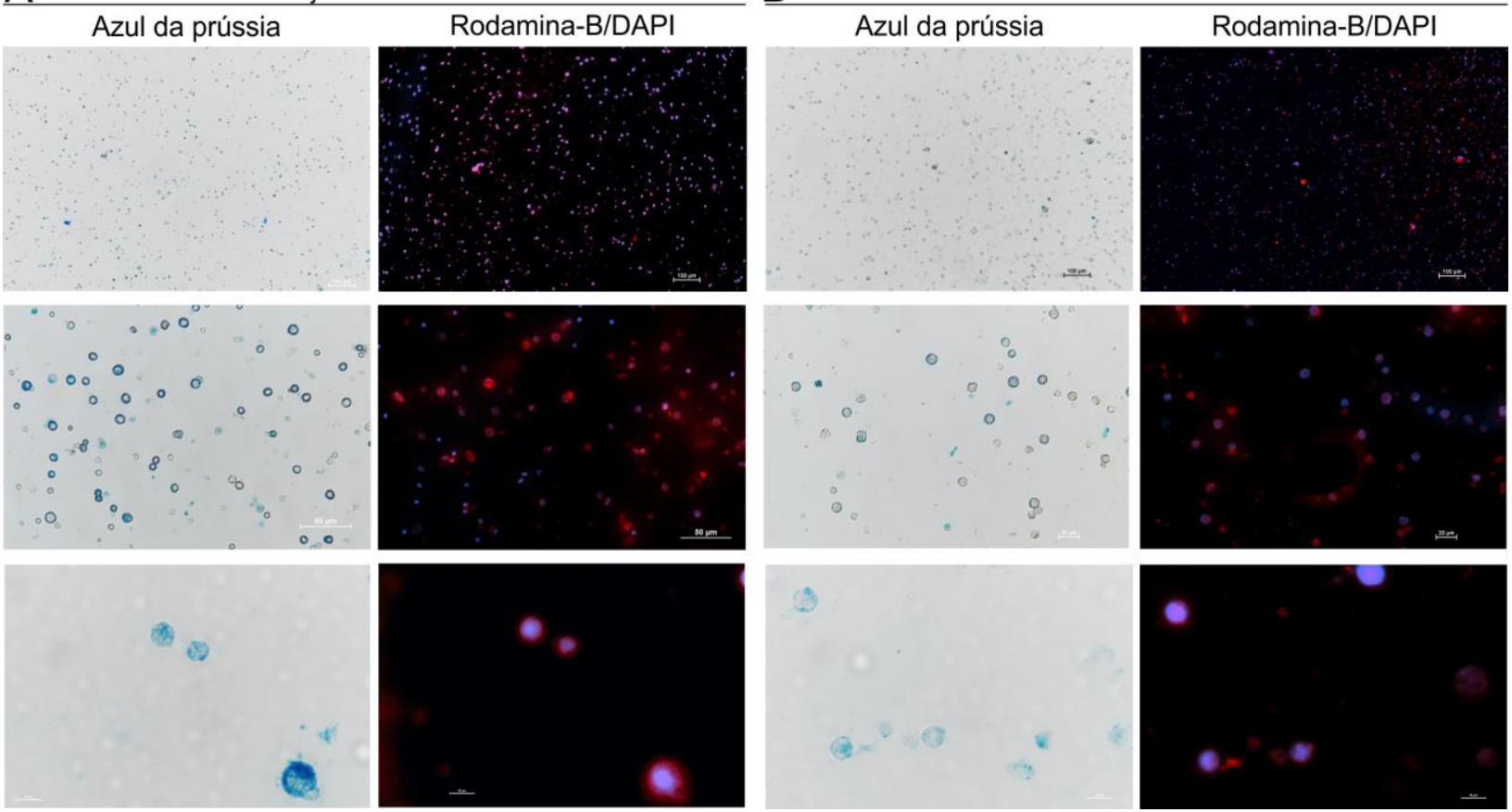

A: Imagem de campo claro e fluorescência de células mononucleares da medula óssea isoladas de camundongos jovens e marcadas com nanopartículas multimodais na concentração de $50 \mu \mathrm{g} / \mathrm{mL}$, as imagens no mesmo aumento são de campos de visão correspondentes, sendo realizada esta correspondência para os três aumentos utilizados (10x, 40x e 100x). B: Imagem de campo claro e fluorescência de células mononucleares da medula óssea isoladas de camundongos idosos e marcadas com nanopartículas multimodais na concentração de $50 \mu \mathrm{g} \mathrm{Fe} / \mathrm{mL}$, as imagens no mesmo aumento são de campos de visão correspondentes.

Figura 27. Microscopia de campo claro e fluorescência de células mononucleares da medula óssea marcadas com nanopartículas multimodais 


\subsubsection{Avaliação da marcação das células mononucleares da medula óssea por imagem de fluorescência no infravermelho próximo e viabilidade após marcação por imagem de bioluminescência}

Após a marcação das CMN-MO de camundongos jovens e idosos com NPMM nas concentrações de 10,30 e $50 \mu \mathrm{g} / \mathrm{mL}$, foram adquiridas imagens de NIRF, como pode ser observado na figura 28A. O sinal de NIRF aumentou de acordo com o aumento da concentração de NPMM, tanto em camundongos jovens quanto em idosos. Para a avaliação da viabilidade das CMN-MO após marcação foram realizadas imagens de BLM, no qual observamos que as células mantiveram a viabilidade após a marcação quando comparadas a intensidade de sinal de células não marcadas (controle), como pode ser visualizada na figura 28B.
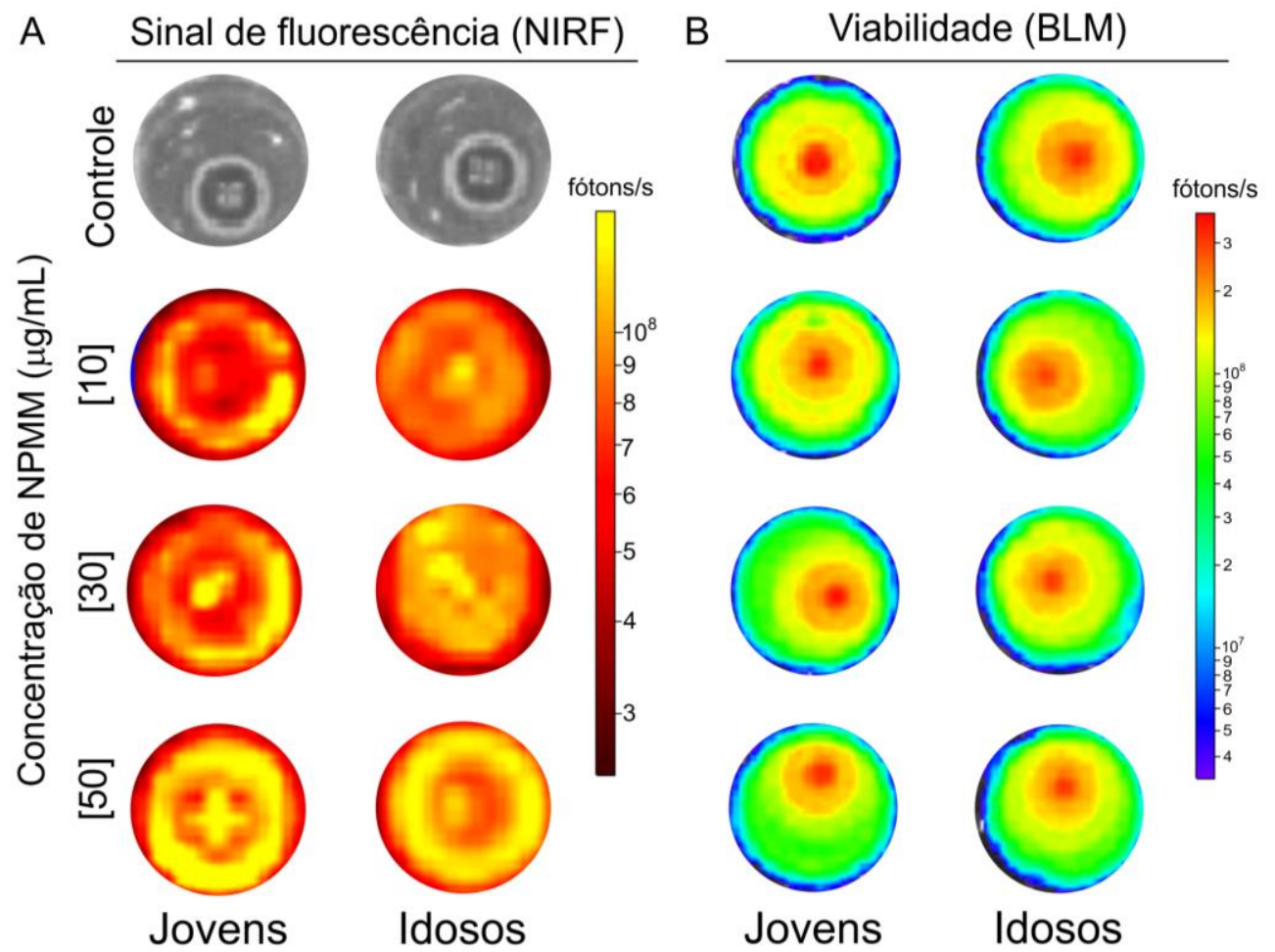

A: Intensidade de fluorescência no infravermelho próximo de células mononucleares da medula óssea de animais jovens e idosos, marcadas com nanopartículas multimodais em três diferentes concentrações. B: Viabilidade por imagem de bioluminescência de células mononucleares da medula óssea de animais jovens e idosos, marcadas com nanopartículas multimodais em três diferentes concentrações após a administração de luciferina.

Figura 28. Avaliação da intensidade de sinal de fluorescência no infravermelho próximo e viabilidade por bioluminescência de células mononucleares da medula óssea de animais jovens de idosos marcadas com nanopartículas multimodais em três concentrações diferentes 
Analisando a quantificação da intensidade do sinal de NIRF das CMN-MO de animais jovens e idosos, marcadas com NPMM nas concentrações de 10, 30 e $50 \mu \mathrm{g} / \mathrm{mL}$ disposto na figura 29 e na tabela 4 , podemos verificar pelo teste de ANOVA que há diferença entre os grupos ( $p<0,001$; Tabela 5). Entretanto, podemos observar pelo teste de post hoc (Tabela 6) que a diferença significativa não ocorre na comparação entre as médias da intensidade do sinal de NIRF dos grupos jovens com os idosos dentro de cada concentração (em 10: $p=0,096$; em 30 e 50: $p=1$ ), somente ocorreu diferença significativa na comparação entre as concentrações de 10, 30 e $50 \mu \mathrm{g} / \mathrm{mL}$ de NPMM ( $\mathrm{p}<0,001)$. Portanto, o aumento da concentração de NPMM difere significativamente na intensidade do sinal de NIRF para ambos os grupos. Os dados acima foram avaliados previamente pelo teste de igualdade de variância de Levene's $(p=0,711)$ para realização dos testes paramétricos.

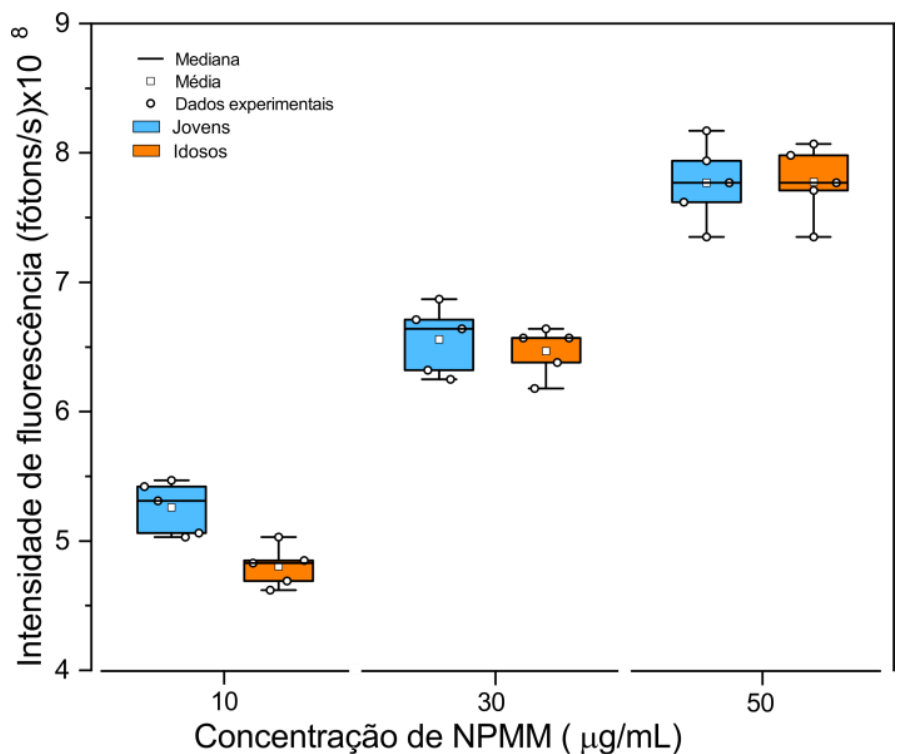

Figura 29. Intensidade de fluorescência no infravermelho próximo de células mononucleares da medula óssea de animais jovens de idosos marcadas com nanopartículas multimodais

Tabela 4. Valores das intensidades de fluorescência no infravermelho próximo das amostras de células mononucleares da medula óssea de animais jovens de idosos marcadas com nanopartículas multimodais

\begin{tabular}{ccccc}
\hline Animal & $\begin{array}{c}\text { Concentração } \\
(\boldsymbol{\mu g} \mathbf{~ N P M M} / \mathbf{m L})\end{array}$ & $\begin{array}{c}\text { Média*10 }^{\mathbf{8}} \\
\text { (fótons/s) }\end{array}$ & Desvio padrão*10 $^{\mathbf{8}}$ & $\mathbf{n}$ \\
\hline Jovem & 10 & 5,26 & 0,20 & 5 \\
Idoso & 10 & 4,80 & 0,16 & 5 \\
Jovem & 30 & 6,56 & 0,26 & 5 \\
Idoso & 30 & 6,47 & 0,19 & 5 \\
Jovem & 50 & 7,77 & 0,31 & 5 \\
Idoso & 50 & 7,78 & 0,28 & 5 \\
\hline
\end{tabular}

NPMM: nanopartículas multimodais; CMN-MO: células mononucleares da medula óssea; NIRF: fluorescência no infravermelho próximo. 
Tabela 5. ANOVA da intensidade de fluorescência no infravermelho próximo das células mononucleares da medula óssea de animais jovens de idosos marcadas com nanopartículas multimodais

\begin{tabular}{cccccc}
\hline $\begin{array}{c}\text { Fonte de } \\
\text { Variação }\end{array}$ & $\begin{array}{c}\text { Soma dos } \\
\text { quadrados }\end{array}$ & $\begin{array}{c}\text { Graus de } \\
\text { liberdade }\end{array}$ & $\begin{array}{c}\text { Quadrado } \\
\text { médio }\end{array}$ & F & Valor-p \\
\hline Aplicações & $3,82 \times 10^{17}$ & 5 & $7,64 \times 10^{16}$ & 132,20 & $<0,001$ \\
Residual & $1,39 \times 10^{16}$ & 24 & $5,78 \times 10^{14}$ & & \\
\hline
\end{tabular}

NPMM: nanopartículas multimodais; CMN-MO: células mononucleares da medula óssea; NIRF: fluorescência no infravermelho próximo.

Tabela 6. Teste de post hoc da intensidade de fluorescência no infravermelho próximo das células mononucleares da medula óssea de animais jovens de idosos marcadas com nanopartículas multimodais

\begin{tabular}{|c|c|c|c|c|c|}
\hline \multicolumn{2}{|c|}{ Grupos } & \multirow{3}{*}{$\begin{array}{c}\begin{array}{c}\text { Diferença } \\
\text { da média }\end{array} \\
4,54 \times 10^{7}\end{array}$} & \multicolumn{2}{|c|}{$\begin{array}{l}\text { 95\% IC da diferença } \\
\text { da média }\end{array}$} & \multirow{3}{*}{$\begin{array}{c}\text { Valor-p } \\
0,096\end{array}$} \\
\hline & & & \multirow{2}{*}{$\begin{array}{l}\text { Inferior } \\
1,52 \times 10^{7}\end{array}$} & \multirow{2}{*}{$\begin{array}{c}\text { Superior } \\
2,97\end{array}$} & \\
\hline c10_jovens & c10_idosos & & & & \\
\hline & c30_jovens & $-1,30 \times 10^{8}$ & $1,52 \times 10^{7}$ & $-8,55$ & $<0,001$ \\
\hline & c30_idosos & $-1,21 \times 10^{8}$ & $1,52 \times 10^{7}$ & $-7,98$ & $<0,001$ \\
\hline & c50_jovens & $-2,51 \times 10^{8}$ & $1,52 \times 10^{7}$ & $-16,52$ & $<0,001$ \\
\hline & c50_idosos & $-2,51 \times 10^{8}$ & $1,52 \times 10^{7}$ & $-16,56$ & $<0,001$ \\
\hline \multirow[t]{4}{*}{ c10_idosos } & c30_jovens & $-1,75 \times 10^{8}$ & $1,52 \times 10^{7}$ & $-11,54$ & $<0,001$ \\
\hline & c30_idosos & $-1,66 \times 10^{8}$ & $1,52 \times 10^{7}$ & $-10,94$ & $<0,001$ \\
\hline & c50_jovens & $-2,97 \times 10^{8}$ & $1,52 \times 10^{7}$ & $-19,51$ & $<0,001$ \\
\hline & c50_idosos & $-2,97 \times 10^{8}$ & $1,52 \times 10^{7}$ & $-19,55$ & $<0,001$ \\
\hline \multirow[t]{3}{*}{ c30_jovens } & c30_idosos & $9,00 \times 10^{6}$ & $1,52 \times 10^{7}$ & 0,59 & 1 \\
\hline & c50_jovens & $-1,21 \times 10^{8}$ & $1,52 \times 10^{7}$ & $-7,97$ & $<0,001$ \\
\hline & c50_idosos & $-1,21 \times 10^{8}$ & $1,52 \times 10^{7}$ & $-8,01$ & $<0,001$ \\
\hline \multirow[t]{2}{*}{ c30_idosos } & c50_jovens & $-1,30 \times 10^{8}$ & $1,52 \times 10^{7}$ & $-8,56$ & $<0,001$ \\
\hline & c50_idosos & $-1,31 \times 10^{8}$ & $1,52 \times 10^{7}$ & $-8,60$ & $<0,001$ \\
\hline c50_jovens & c50_idosos & $-6,00 \times 10^{6}$ & $1,52 \times 10^{7}$ & $-0,04$ & 1 \\
\hline
\end{tabular}

NPMM: nanopartículas multimodais; CMN-MO: células mononucleares da medula óssea; NIRF: fluorescência no infravermelho próximo.

Analisando a quantificação da intensidade do sinal de BLM quanto à viabilidade celular das células marcadas com NPMM nas concentrações controle, 10, 30 e $50 \mu \mathrm{g} / \mathrm{mL}$ entre os grupos (animais jovens e idosos), conforme mostrado na figura 30 e na tabela 7 , podemos verificar pelo teste de ANOVA que há diferença significativa $(p<0,001)$ entre os grupos (Tabela 8). Entretanto, pela análise de post hoc (Tabela 9), podemos verificar que não há diferença entre os grupos (jovens e idosos) em nenhuma das concentrações analisadas $(p=1)$, a diferença significativa ocorre nas comparações entre as concentrações de 30 e $50 \mu \mathrm{g} / \mathrm{mL}$ de NPMM com relação ao controle (30 e 50: $p<0,001$ ), tanto para células de animais jovens quanto para animais idosos, também foi observada diferença significativa na comparação da concentração de 10 com relação à de $50 \mu \mathrm{g} / \mathrm{mL}$ de NPMM $(p<0,001)$ em animais jovens e idosos, não havendo diferença 
significativa entre as concentrações de 30 e $50 \mu \mathrm{g} / \mathrm{mL}$ (jovens: $p=0,114$ e idosos: $p=1$ ). Também pode ser observado que a redução da viabilidade é inferior a $5 \%$ na comparação da maior concentração de NPMM $(50 \mu \mathrm{g} / \mathrm{mL})$ utilizadas para marcação com relação ao controle, o que representa uma baixa redução da viabilidade mesmo utilizando a maior concentração da NPMM (Figura 30). Os dados acima foram avaliados previamente pelo teste de igualdade de variância de Levene's $(p=0,285)$ para realização dos testes.

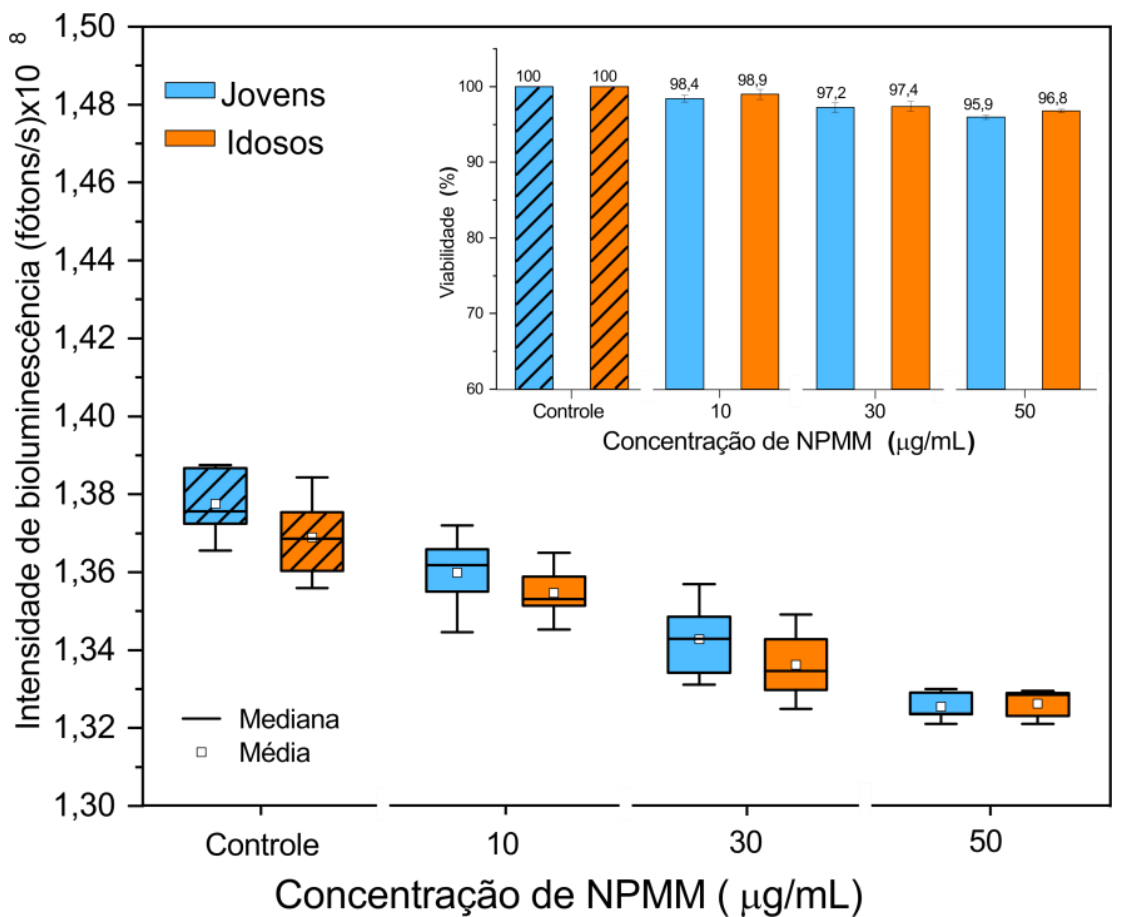

NPMM: nanopartículas multimodais.

Figura 30. Representação gráfica da intensidade bioluminescência de células mononucleares da medula óssea de animais jovens de idosos marcadas com nanopartículas multimodais em diferentes concentrações

Tabela 7. Valores das intensidades de bioluminescência das amostras de células mononucleares da medula óssea de animais jovens e idosos marcadas com nanopartículas multimodais

\begin{tabular}{ccccc}
\hline Animal & $\begin{array}{c}\text { Concentração } \\
(\boldsymbol{\mu g} \mathbf{~ N P M M} / \mathbf{m L})\end{array}$ & $\begin{array}{c}\text { Média*10 }^{\mathbf{8}} \\
\text { (fótons/s) }\end{array}$ & Desvio padrão*10 $^{\mathbf{8}}$ & $\mathbf{n}$ \\
\hline Jovem & 0 & 1,378 & 0,009 & 5 \\
Idoso & 0 & 1,369 & 0,001 & 5 \\
Jovem & 10 & 1,360 & 0,001 & 5 \\
Idoso & 10 & 1,355 & 0,007 & 5 \\
Jovem & 30 & 1,343 & 0,001 & 5 \\
Idoso & 30 & 1,336 & 0,009 & 5 \\
Jovem & 50 & 1,325 & 0,003 & 5 \\
Idoso & 50 & 1,326 & 0,003 & 5 \\
\hline
\end{tabular}

NPMM: nanopartículas multimodais; CMN-MO: células mononucleares da medula óssea; BLM: bioluminescência. 
Tabela 8. ANOVA da intensidade de bioluminescência das células mononucleares da medula óssea marcadas com nanopartículas multimodais

\begin{tabular}{cccccc}
\hline $\begin{array}{c}\text { Fonte de } \\
\text { Variação }\end{array}$ & $\begin{array}{c}\text { Soma dos } \\
\text { quadrados }\end{array}$ & $\begin{array}{c}\text { Graus de } \\
\text { liberdade }\end{array}$ & $\begin{array}{c}\text { Quadrado } \\
\text { médio }\end{array}$ & F & Valor-p \\
\hline Aplicações & $1,32 \times 10^{14}$ & 7 & $1,88 \times 10^{13}$ & 24,10 & $<0,001$ \\
Residual & $2,50 \times 10^{13}$ & 32 & $7,81 \times 10^{11}$ & & \\
\hline
\end{tabular}

NPMM: nanopartículas multimodais; CMN-MO: células mononucleares da medula óssea; BLM: bioluminescência.

Tabela 9. Teste de post hoc da intensidade de bioluminescência das células mononucleares da medula óssea marcadas com nanopartículas multimodais

\begin{tabular}{|c|c|c|c|c|c|}
\hline \multirow{2}{*}{\multicolumn{2}{|c|}{ Grupos }} & \multirow{3}{*}{$\begin{array}{l}\begin{array}{l}\text { Diferença } \\
\text { da média }\end{array} \\
8,66 \times 10^{5}\end{array}$} & \multicolumn{2}{|c|}{ 95\% IC da diferença da média } & \multirow{3}{*}{$\frac{\text { Valor-p }}{1}$} \\
\hline & & & \multirow{2}{*}{$\begin{array}{c}\text { Inferior } \\
5,59 \times 10^{5}\end{array}$} & \multirow{2}{*}{$\begin{array}{c}\text { Superior } \\
1,55\end{array}$} & \\
\hline ctrl_jovens & ctrl_idosos & & & & \\
\hline & c10_jovens & $1,77 \times 10^{6}$ & $5,59 \times 10^{5}$ & 3,17 & 0,094 \\
\hline & c10_idosos & $2,28 \times 10^{6}$ & $5,59 \times 10^{5}$ & 4,09 & 0,008 \\
\hline & c30_jovens & $3,48 \times 10^{6}$ & $5,59 \times 10^{5}$ & 6,22 & $<0,001$ \\
\hline & c30_idosos & $4,13 \times 10^{6}$ & $5,59 \times 10^{5}$ & 7,39 & $<0,001$ \\
\hline & c50_jovens & $5,21 \times 10^{6}$ & $5,59 \times 10^{5}$ & 9,32 & $<0,001$ \\
\hline & c50_idosos & $5,13 \times 10^{6}$ & $5,59 \times 10^{5}$ & 9,18 & $<0,001$ \\
\hline \multirow[t]{6}{*}{ ctrl_idosos } & c10_jovens & $9,06 \times 10^{5}$ & $5,59 \times 10^{5}$ & 1,62 & 1 \\
\hline & c10_idosos & $1,42 \times 10^{6}$ & $5,59 \times 10^{5}$ & 2,54 & 0,454 \\
\hline & c30_jovens & $2,61 \times 10^{6}$ & $5,59 \times 10^{5}$ & 4,68 & 0,001 \\
\hline & c30_idosos & $3,27 \times 10^{6}$ & $5,59 \times 10^{5}$ & 5,84 & $<0,001$ \\
\hline & c50_jovens & $4,34 \times 10^{6}$ & $5,59 \times 10^{5}$ & 7,77 & $<0,001$ \\
\hline & c50_idosos & $4,27 \times 10^{6}$ & $5,59 \times 10^{5}$ & 7,63 & $<0,001$ \\
\hline \multirow[t]{5}{*}{ c10_jovens } & c10_idosos & $5,12 \times 10^{5}$ & $5,59 \times 10^{5}$ & 0,92 & 1 \\
\hline & c30_jovens & $1,70 \times 10^{6}$ & $5,59 \times 10^{5}$ & 3,05 & 0,127 \\
\hline & c30_idosos & $2,36 \times 10^{6}$ & $5,59 \times 10^{5}$ & 4,30 & 0,005 \\
\hline & c50_jovens & $3,44 \times 10^{6}$ & $5,59 \times 10^{5}$ & 6,15 & $<0,001$ \\
\hline & c50_idosos & $3,36 \times 10^{6}$ & $5,59 \times 10^{5}$ & 6,01 & $<0,001$ \\
\hline \multirow[t]{4}{*}{ c10_idosos } & c30_jovens & $1,19 \times 10^{6}$ & $5,59 \times 10^{5}$ & 2,14 & 1 \\
\hline & c30_idosos & $1,85 \times 10^{6}$ & $5,59 \times 10^{5}$ & 3,30 & 0,066 \\
\hline & c50_jovens & $2,92 \times 10^{6}$ & $5,59 \times 10^{5}$ & 5,23 & $<0,001$ \\
\hline & c50_idosos & $2,85 \times 10^{6}$ & $5,59 \times 10^{5}$ & 5,09 & $<0,001$ \\
\hline \multirow[t]{3}{*}{ c30_jovens } & c30_idosos & $6,52 \times 10^{5}$ & $5,59 \times 10^{5}$ & 1,17 & 1 \\
\hline & c50_jovens & $1,73 \times 10^{6}$ & $5,59 \times 10^{5}$ & 3,10 & 0,114 \\
\hline & c50 idosos & $1,65 \times 10^{6}$ & $5,59 \times 10^{5}$ & 2,96 & 0,162 \\
\hline \multirow[t]{2}{*}{ c30_idosos } & c50_jovens & $1,08 \times 10^{6}$ & $5,59 \times 10^{5}$ & 1,93 & 1 \\
\hline & c50_idosos & $1,00 \times 10^{6}$ & $5,59 \times 10^{5}$ & 1,80 & 1 \\
\hline c50 jovens & c50_idosos & $-7,7610^{5}$ & $5,59 \times 10^{5}$ & $-0,14$ & 1 \\
\hline
\end{tabular}

NPMM: nanopartículas multimodais; CMN-MO: células mononucleares da medula óssea; BLM: bioluminescência. ctrl: controle. 


\subsubsection{Avaliação da marcação das células mononucleares da medula óssea por imagem de ressonância magnética}

Após a marcação das CMN-MO com NPMM foram encontrados os valores de T2 a partir das intensidades do sinal de IRM entre os grupos (células de animais jovens e idosos) e (células marcadas e não marcadas com NPMM), conforme mostrado na figura 31 e tabela 10.

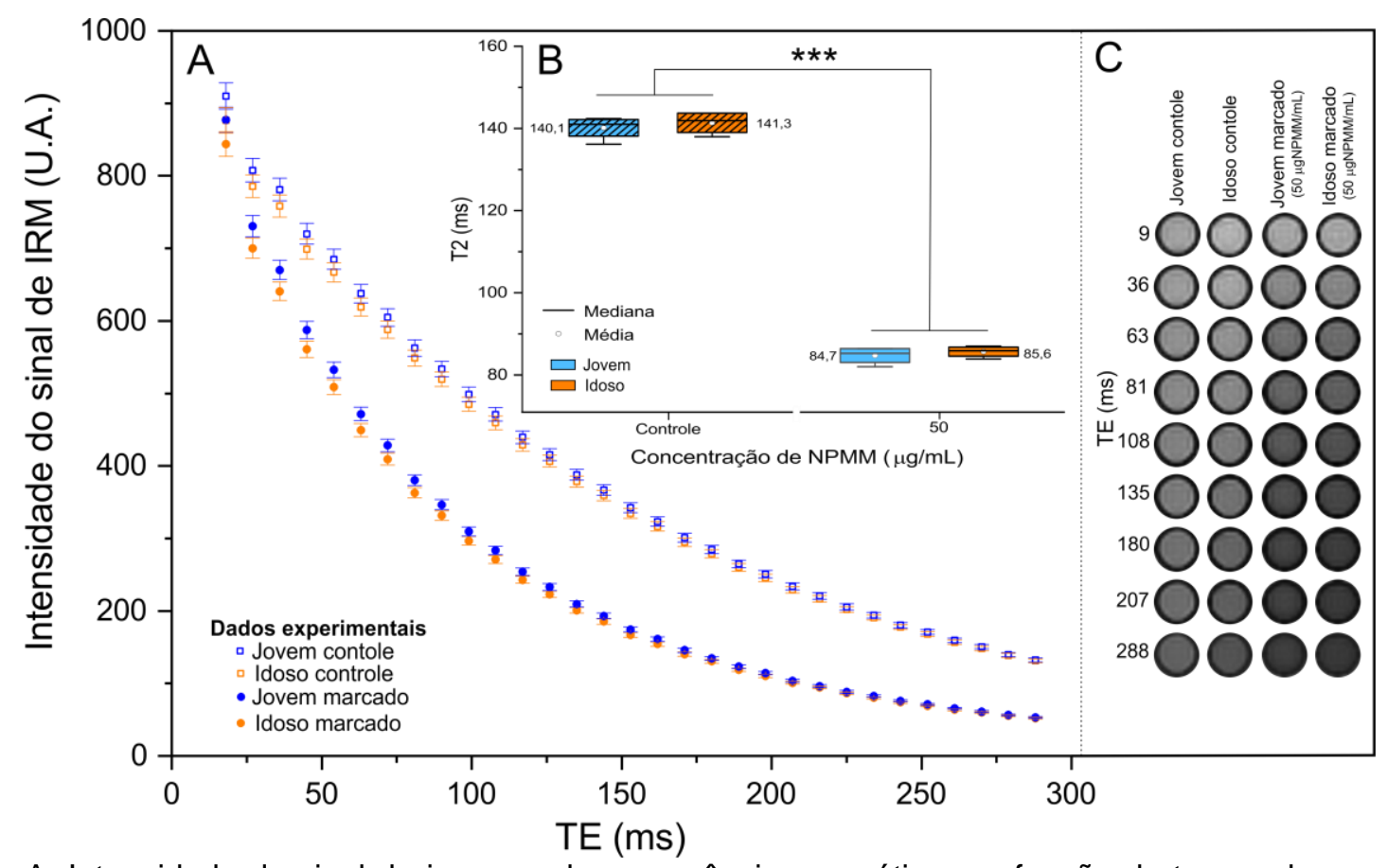

A: Intensidade do sinal de imagem de ressonância magnética em função do tempo de eco para amostras de células mononucleares da medula óssea marcadas com nanopartículas multimodais $(50 \mu \mathrm{g} / \mathrm{mL})$ para camundongos jovens e idosos. B: Valores de T2 de células mononucleares da medula óssea marcados com seus respectivos controles. C: Imagem de ressonância magnética do phantom de agarose contendo células mononucleares da medula óssea marcadas e seus respectivos controles em função do tempo de eco.

Figura 31. Avaliação da intensidade do sinal de ressonância magnética nas células mononucleares da medula óssea marcadas com nanopartículas multimodais

Pelo teste de ANOVA podemos verificar que há diferença entre os grupos ( $\mathrm{p}<0,001$; Tabela 11). Entretanto, através da análise de post hoc (Tabela 12) podemos verificar que a diferença significativa não ocorre entre os grupos de células de animais jovens e idosos $(p=1)$, somente na comparação entre as condições células marcadas NPMM na concentração de $50 \mu \mathrm{g} / \mathrm{mL}$ e não marcadas ( $p<0,001)$, conforme mostrado na tabela 12. Portanto, a marcação das células muda significativamente 0 sinal de IRM para ambos os grupos. Os dados acima foram avaliados previamente pelo teste de igualdade de variância de Levene's $(p=0,416)$ para realização dos testes. 
Tabela 10. Valores de relaxação spin-spin das amostras de células mononucleares da medula óssea de animais jovens e idosos marcadas com nanopartículas multimodais obtidas pela imagem de ressonância magnética

\begin{tabular}{ccccc}
\hline Animal & $\begin{array}{c}\text { Concentração } \\
(\boldsymbol{\mu g} \text { NPMM/mL) }\end{array}$ & $\begin{array}{c}\text { Média } \\
(\mathbf{U} . \mathbf{A})\end{array}$ & Desvio padrão & $\mathbf{n}$ \\
\hline Jovem & 0 & 140,15 & 2,83 & 4 \\
Idoso & 0 & 141,38 & 2,84 & 4 \\
Jovem & 50 & 84,73 & 2,12 & 4 \\
Idoso & 50 & 85,67 & 1,40 & 4 \\
\hline
\end{tabular}

NPMM: nanopartículas multimodais; CMN-MO: células mononucleares da medula óssea; IRM: imagem de ressonância magnética.

Tabela 11. ANOVA dos valores de relaxação spin-spin das amostras de imagem de ressonância magnética das células mononucleares da medula óssea marcadas com nanopartículas multimodais

\begin{tabular}{cccccc}
\hline $\begin{array}{c}\text { Fonte de } \\
\text { Variação }\end{array}$ & $\begin{array}{c}\text { Soma dos } \\
\text { quadrados }\end{array}$ & $\begin{array}{c}\text { Graus de } \\
\text { liberdade }\end{array}$ & $\begin{array}{c}\text { Quadrado } \\
\text { médio }\end{array}$ & F & Valor-p \\
\hline Aplicações & 12354,78 & 3 & 4118,26 & 732,52 & $<0,001$ \\
Residual & 67,47 & 12 & 5,62 & & \\
\hline
\end{tabular}

NPMM: nanopartículas multimodais; CMN-MO: células mononucleares da medula óssea; IRM: imagem de ressonância magnética.

Tabela 12. Teste de post hoc dos valores de T2 de imagem de ressonância magnética das amostras de células mononucleares da medula óssea de animais jovens e idosos marcadas com nanopartículas multimodais

\begin{tabular}{|c|c|c|c|c|c|}
\hline \multicolumn{2}{|c|}{ Grupos } & \multirow{3}{*}{$\begin{array}{c}\begin{array}{c}\text { Diferença } \\
\text { da média }\end{array} \\
-55,42\end{array}$} & \multicolumn{2}{|c|}{$\begin{array}{l}\text { IC 95\% da diferença da } \\
\text { média }\end{array}$} & \multirow{3}{*}{$\begin{array}{l}\text { Valor-p } \\
<0,001\end{array}$} \\
\hline & & & \multirow{2}{*}{$\begin{array}{c}\text { Inferior } \\
1,68\end{array}$} & \multirow{2}{*}{$\begin{array}{c}\text { Superior } \\
-33,05\end{array}$} & \\
\hline c50_jovens & ctrl_jovens & & & & \\
\hline & ctrl_idosos & $-56,64$ & 1,68 & $-33,79$ & $<0,001$ \\
\hline & c50_idosos & $-0,93$ & 1,68 & $-0,56$ & 1 \\
\hline \multirow[t]{2}{*}{ ctrl_jovens } & ctrl_idosos & $-1,22$ & 1,68 & $-0,73$ & 1 \\
\hline & c50_idosos & 54,49 & 1,68 & 32,50 & $<0,001$ \\
\hline ctrl_idosos & c50_idosos & 55,71 & 1,68 & 33,29 & $<0,001$ \\
\hline
\end{tabular}

NPMM: nanopartículas multimodais; CMN-MO: células mononucleares da medula óssea; IRM: imagem de ressonância magnética; ctrl: controle.

\subsubsection{Quantificação do ferro internalizado nas células mononucleares da medula óssea de camundongos jovens e idosos}

\subsubsection{Quantificação por imagem de fluorescência no infravermelho próximo}

A quantificação de ferro pela técnica de NIRF foi feita inicialmente com a construção de uma curva de calibração como é mostrada na figura 32 que relaciona a intensidade do sinal do NIRF em fótons/s com a concentração de ferro em $\mu \mathrm{g} / \mathrm{mL}$. Após o ajuste linear da curva de calibração foi obtida a relação: 
$[\mathrm{Fe}]=(-7,23 \pm 5,56) \times 10^{7}+(1,91 \pm 0,65) \times 10^{8} \times[\mathrm{NPMM}]$

Utilizando a curva de calibração foi obtida a quantificação da carga de ferro por célula e a quantidade de NPMM correspondente. Para a concentração de marcação de $10 \mu \mathrm{g} \mathrm{Fe} / \mathrm{mL}$ foi encontrado 2,27 $\pm 0,09 \mathrm{pg} \mathrm{Fe} / \mathrm{CMN}-\mathrm{MO}$ ou $(2,85 \pm 0,11) \times 10^{4}$ NPMM/CMN-MO de camundongos jovens e nas CMN-MO de camundongos idosos foi encontrado $2,07 \pm 0,07 \mathrm{pg}$ Fe/CMN-MO ou $(2,61 \pm 0,84) \times 10^{4}$ NPMM/CMN-MO. Para a concentração de marcação de $30 \mu \mathrm{g} \mathrm{Fe} / \mathrm{mL}$ foi encontrado 3,06 $\pm 0,12 \mathrm{pg} \mathrm{Fe} / \mathrm{CMN}-\mathrm{MO}$ ou $(3,85 \pm 0,16) \times 10^{4}$ NPMM/CMN-MO de camundongos jovens e nas CMN-MO de camundongos idosos $3,02 \pm 0,09 \mathrm{pg}$ Fe/CMN-MO ou $(3,79 \pm 0,11) \times 10^{4} \mathrm{NPMM} / \mathrm{CMN}-\mathrm{MO}$. Para a concentração de marcação de $50 \mu \mathrm{g} F / \mathrm{mL}$ foi encontrado $3,98 \pm 0,16 \mathrm{pg}$ Fe/CMN-MO ou $(5,00 \pm 0,20) \times 10^{4}$ NPMM/CMN-MO de camundongos jovens e nas CMN-MO de camundongos idosos $3,98 \pm 0,14 \mathrm{pg}$ Fe/CMN-MO ou $(5,00 \pm 0,18) \times 10^{4}$ NPMM/CMN-MO (Figura 33 e Tabela 13).

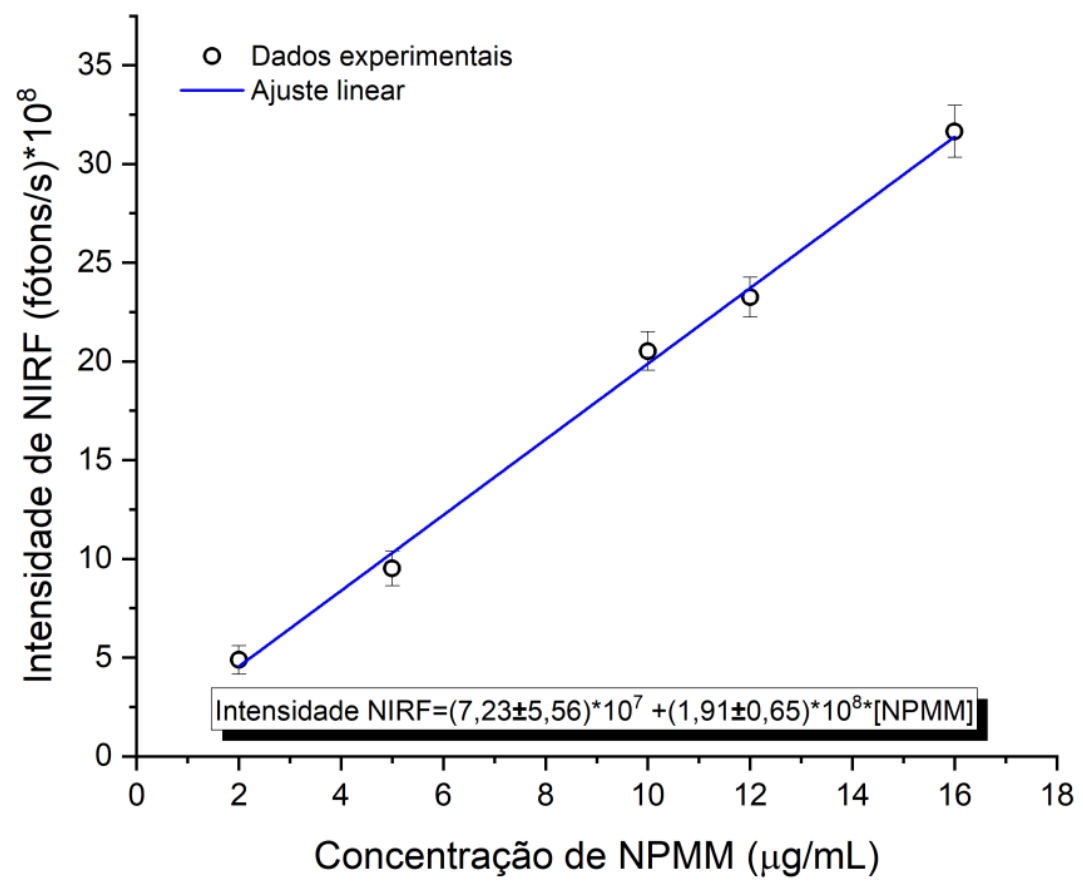

Figura 32. Curva de calibração de fluorescência no infravermelho próximo a partir de concentrações conhecidas de nanopartículas multimodais 


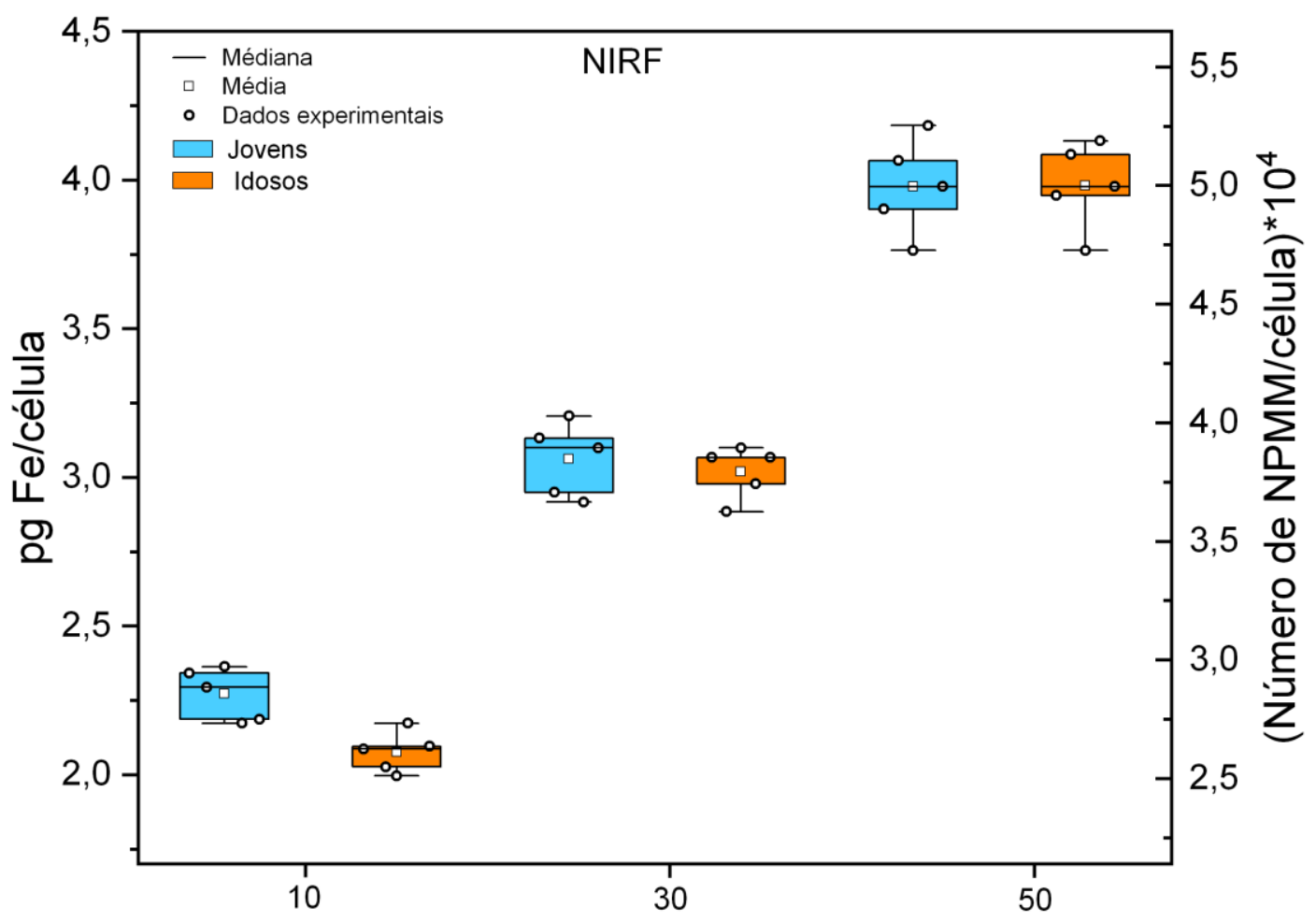

Concentração de NPMM na marcação celular $(\mu \mathrm{g} / \mathrm{mL})$

Figura 33. Quantificação pela técnica de fluorescência no infravermelho próximo da internalização de nanopartículas multimodais/células mononucleares da medula óssea após marcação nas concentrações de 10, 30 e $50 \mu \mathrm{g} \mathrm{Fe} / \mathrm{mL}$ comparando as células mononucleares da medula óssea de camundongos jovens e idosos

Tabela 13. Valores das da quantificação do ferro internalizado nas CMN-MO por NIRF de animais jovens e idosos marcadas com NPMM

\begin{tabular}{ccccc}
\hline Animal & $\begin{array}{c}\text { Concentração } \\
(\boldsymbol{\mu g ~ F e} / \mathbf{m L})\end{array}$ & $\begin{array}{c}\text { pg Fe/Célula } \\
(\text { Média } \pm \text { DP })\end{array}$ & $\begin{array}{c}\text { № de NPMM/Célula*10 } \\
(\text { Média } \pm \text { DP) }\end{array}$ & $\mathbf{n}$ \\
\hline Jovens & 10 & $2,27 \pm 0,09$ & $2,85 \pm 0,11$ & 5 \\
Idosos & 10 & $2,07 \pm 0,07$ & $2,61 \pm 0,84$ & 5 \\
Jovens & 30 & $3,06 \pm 0,12$ & $3,85 \pm 0,16$ & 5 \\
Idosos & 30 & $3,02 \pm 0,09$ & $3,79 \pm 0,11$ & 5 \\
Jovens & 50 & $3,98 \pm 0,16$ & $5,00 \pm 0,20$ & 5 \\
Idosos & 50 & $3,98 \pm 0,14$ & $5,00 \pm 0,18$ & 5 \\
\hline
\end{tabular}

NPMM: nanopartículas multimodais; CMN-MO: células mononucleares da medula óssea; NIRF: fluorescência no infravermelho próximo.

Os dados da quantificação de ferro internalizada nas CMN-MO avaliados por NIRF foram analisados quanto à diferença na concentração de ferro utilizada na marcação e entre o uso de células de camundongos jovens e idosos, verificamos pelo teste de ANOVA que a quantificação para estes fatores tanto em pg $\mathrm{Fe} / c e ́ l u l a s$ quanto por número de NPMM/células apresentaram diferença significativa $(p<0,001)$, como mostrado na tabela 14 e na análise de post hoc (Tabela 15) foi verificado que as comparações que tiveram diferença significativa $(p<0,01)$, ocorreram 
entre as diferentes concentrações (10, 30 e $50 \mu \mathrm{g} \mathrm{Fe} / \mathrm{mL}$ ), pois na comparação entre os grupos (jovens e idosos) para a mesma concentração não houve diferença significativa

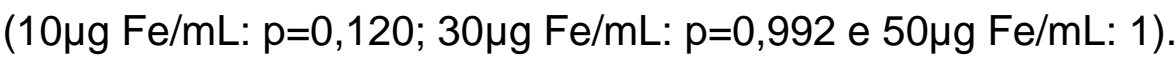

Tabela 14. ANOVA da quantificação do ferro internalizado nas CMN-MO por NIRF

\begin{tabular}{ccccccc}
\hline Internalização & $\begin{array}{c}\text { Fonte de } \\
\text { variação }\end{array}$ & $\begin{array}{c}\text { Soma dos } \\
\text { quadrados }\end{array}$ & $\begin{array}{c}\text { Graus de } \\
\text { liberdade }\end{array}$ & $\begin{array}{c}\text { Quadrado } \\
\text { médio }\end{array}$ & F & Valor-p \\
\hline \multirow{2}{*}{ pg Fe/Célula } & Aplicações & 16,419 & 5 & 3,284 & 242,47 & $<0,001$ \\
& Residual & 0,325 & 24 & 0,014 & & \\
NNo de & Aplicações & $2,59 \times 10^{9}$ & 5 & $5,19 \times 10^{8}$ & 245,47 & $<0,001$ \\
NPMM/Célula & Residual & $5,07 \times 10^{7}$ & 24 & $2,11 \times 10^{6}$ & & \\
\hline
\end{tabular}

NPMM: nanopartículas multimodais; CMN-MO: células mononucleares da medula óssea; NIRF: fluorescência no infravermelho próximo.

Tabela 15. Teste de post hoc da quantificação do ferro internalizado nas Células mononucleares da medula óssea por fluorescência no infravermelho próximo

\begin{tabular}{|c|c|c|c|c|c|}
\hline \multicolumn{2}{|c|}{ Grupos } & \multirow{2}{*}{$\begin{array}{c}\begin{array}{c}\text { Diferença } \\
\text { da média }\end{array} \\
0,19\end{array}$} & \multirow{2}{*}{$\begin{array}{c}\text { Erro padrão } \\
0,07\end{array}$} & \multirow{2}{*}{$\begin{array}{c}\mathbf{t} \\
2,66\end{array}$} & \multirow{2}{*}{$\begin{array}{c}\text { Valor-p } \\
0,120\end{array}$} \\
\hline c10_jovens & c10_idosos & & & & \\
\hline & c30_jovens & $-0,78$ & 0,07 & $-10,72$ & $<, 001$ \\
\hline & c30_idosos & $-0,74$ & 0,07 & $-10,15$ & $<, 001$ \\
\hline & c50_jovens & $-1,70$ & 0,07 & $-23,18$ & $<, 001$ \\
\hline & c50_idosos & $-1,71$ & 0,07 & $-23,22$ & $<, 001$ \\
\hline \multirow[t]{4}{*}{ c10_idosos } & c30_jovens & $-0,98$ & 0,07 & $-13,38$ & $<, 001$ \\
\hline & c30_idosos & $-0,94$ & 0,07 & $-12,81$ & $<, 001$ \\
\hline & c50_jovens & $-1,90$ & 0,07 & $-25,85$ & $<, 001$ \\
\hline & c50_idosos & $-1,90$ & 0,07 & $-25,89$ & $<, 001$ \\
\hline \multirow[t]{3}{*}{ c30_jovens } & c30_idosos & 0,04 & 0,07 & 0,57 & 0,992 \\
\hline & c50_jovens & $-0,91$ & 0,07 & $-12,46$ & $<, 001$ \\
\hline & c50_idosos & $-0,92$ & 0,07 & $-12,50$ & $<, 001$ \\
\hline \multirow[t]{2}{*}{ c30_idosos } & c50_jovens & $-0,95$ & 0,07 & $-13,03$ & $<, 001$ \\
\hline & c50_idosos & $-0,96$ & 0,07 & $-13,07$ & $<, 001$ \\
\hline c50_jovens & c50_idosos & $-0,01$ & 0,07 & $-0,04$ & 1,000 \\
\hline
\end{tabular}

NPMM: nanopartículas multimodais; CMN-MO: células mononucleares da medula óssea; NIRF: fluorescência no infravermelho próximo.

\subsubsection{Quantificação por imagem de ressonância magnética}

Para a quantificação de NPMM internalizado nas CMN-MO pela técnica de IRM foi utilizado os valores de T2 calculados na tabela 10, o valor de r2 $(19,9 \pm 0,9) \times 10-4 \mathrm{~ms}^{-1} \mu \mathrm{g} \mathrm{Fe}{ }^{-1} \mathrm{~mL}$ para este tipo de NPMM e com o uso das equações $4 \mathrm{e}$ 5 foram determinados os valores da carga de ferro por célula e a quantidade de NPMM correspondente. Para a concentração de marcação com $50 \mu \mathrm{g} \mathrm{Fe} / \mathrm{mL}$, única 


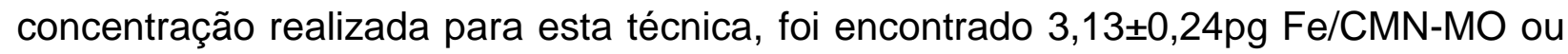
$(3,93 \pm 0,30) \times 10^{4}$ NPMM/CMN-MO de camundongos jovens e nas CMN-MO de camungongos idosos foram encontradas $3,08 \pm 0,17 \mathrm{pg}$ Fe/CMN-MO ou $(3,87 \pm 0,21) \times 10^{4}$ NPMM/CMN-MO (Figura 34 e Tabela 16).

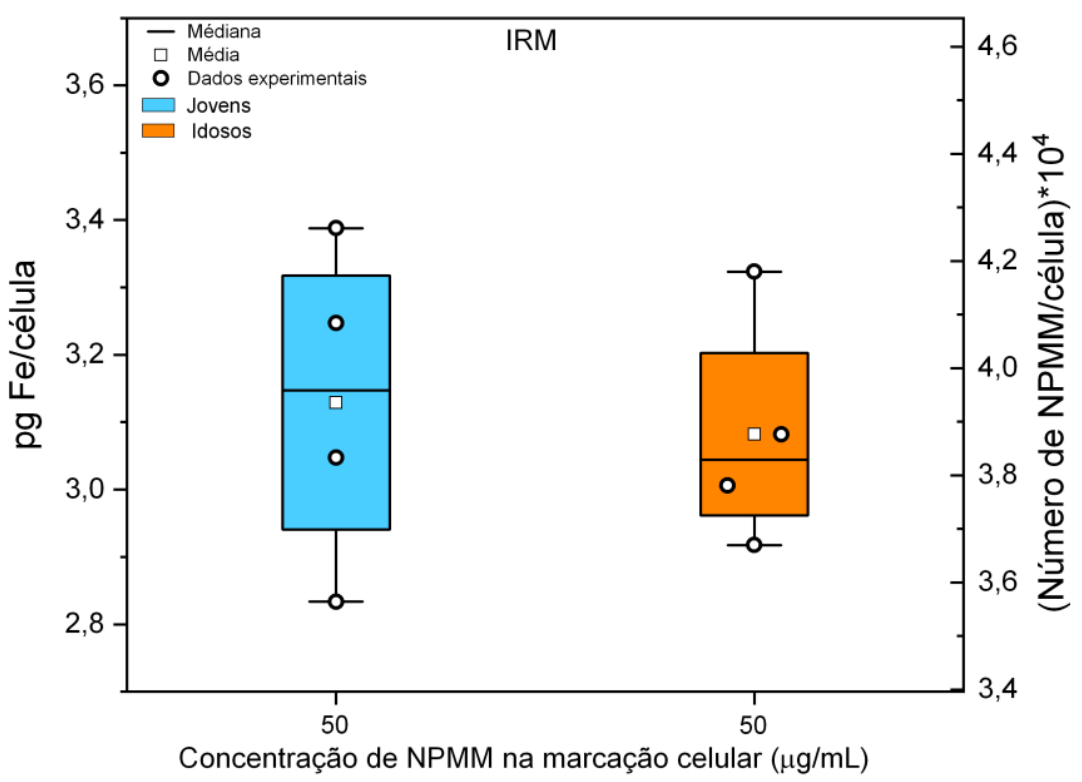

Figura 34. Quantificação pela técnica de imagem de ressonância magnética da internalização de nanopartículas multimodais/células mononucleares da medula óssea após marcação na concentração de $50 \mu \mathrm{g} \mathrm{Fe} / \mathrm{mL}$ comparando as células mononucleares da medula óssea de camundongos jovens e idosos

Tabela 16. Valores da quantificação do ferro internalizado nas células mononucleares da medula óssea de animais jovens e idosos marcadas com nanopartículas multimodais por imagem de ressonância magnética

\begin{tabular}{ccccc}
\hline Animal & $\begin{array}{c}\text { Concentração } \\
(\boldsymbol{\mu g ~ N P M M} / \mathbf{m L})\end{array}$ & $\begin{array}{c}\text { pg Fe/célula } \\
(\text { Média } \pm \text { DP) }\end{array}$ & $\begin{array}{c}\text { № de NPMM/célula*10 } \\
(\text { Média } \pm \text { DP) }\end{array}$ & $\mathbf{n}$ \\
\hline Jovens & 50 & $3,13 \pm 0,24$ & $3,93 \pm 0,30$ & 4 \\
Idosos & 50 & $3,08 \pm 0,17$ & $3,87 \pm 0,22$ & 4 \\
\hline
\end{tabular}

NPMM: nanopartículas multimodais; CMN-MO: células mononucleares da medula óssea; IRM: imagem de ressonância magnética.

A quantificação de ferro internalizada nas $\mathrm{CMN}-\mathrm{MO}$ avaliados por IRM foi avaliado pelo teste $t$ de Student e não mostrou diferença significativa entre os grupos (jovens e idosos) na marcação com $50 \mu \mathrm{g} \mathrm{Fe} / \mathrm{mL}(p=0,764)$ para pg Fe/células e $(\mathrm{p}=0,770)$ para número de NPMM/células, como mostrado na tabela 17. 
Tabela 17. Teste $t$ da quantificação do ferro internalizado nas células mononucleares da medula óssea por imagem de ressonância magnética de animais jovens e idosos marcadas com nanopartículas multimodais

\begin{tabular}{cccc}
\hline Internalização & $\mathbf{t}$ & Graus de liberdade & Valor-p \\
\hline pg Fe/Células & 0,36 & 6 & 0,764 \\
$\mathrm{n}$ o de NPMM/Células & 0,30 & 6 & 0,770 \\
\hline
\end{tabular}

NPMM: nanopartículas multimodais; CMN-MO: células mononucleares da medula óssea; IRM: imagem de ressonância magnética.

\subsubsection{Quantificação por espectrometria de massa por plasma indutivamente acoplado}

O processo de quantificação pela técnica de ICP-MS foi iniciado com a construção da curva de calibração como mostrado na figura 35 que relaciona a intensidade do sinal em contas por segundo (CPS) em função da concentração de ferro em ppb. Após o ajuste linear da curva de calibração foi obtida a seguinte relação:

$$
[\mathrm{Fe}]=(-47,28 \pm 0,72)+(5,27 \pm 0,04) \times[\text { Intensidade do sinal] }
$$

Com o uso da curva de calibração foi obtida a quantificação da carga de ferro por célula e a quantidade de NPMM correspondente. Para a concentração de

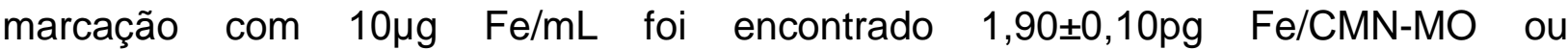
$(2,39 \pm 0,12) \times 10^{4} \quad \mathrm{NPMM} / \mathrm{CMN}-\mathrm{MO}$ de camundongos jovens e nas CMN-MO de camundongos idosos foi encontrado $1,67 \pm 0,06 \mathrm{pg}$ Fe/CMN-MO ou $(2,10 \pm 0,74) \times 10^{4}$ NPMM/CMN-MO. Para a concentração de marcação de $30 \mu \mathrm{g} \mathrm{Fe} / \mathrm{mL}$ foi encontrado $3,21 \pm 0,07 \mathrm{pg} F \mathrm{Fe} / \mathrm{CMN}-\mathrm{MO}$ ou $(4,03 \pm 0,93) \times 10^{4} \mathrm{NPMM} / \mathrm{CMN}-\mathrm{MO}$ de camundongos

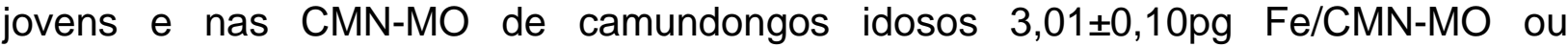
$(3,78 \pm 0,13) \times 10^{4} \mathrm{NPMM} / \mathrm{CMN}-\mathrm{MO}$. Para a concentração de marcação de $50 \mu \mathrm{g} \mathrm{Fe} / \mathrm{mL}$ foi encontrado 4,23 $\pm 0,09 \mathrm{pg} \mathrm{Fe} / \mathrm{CMN}-\mathrm{MO}$ ou $(5,32 \pm 0,11) \times 10^{4}$ NPMM/CMN-MO de camundongos jovens e nas CMN-MO de camundongos idosos 4,00 0,07pg Fe/CMNMO ou $(5,03 \pm 0,81) \times 10^{4}$ NPMM/CMN-MO (Tabela 18 e Figura 36 ). 


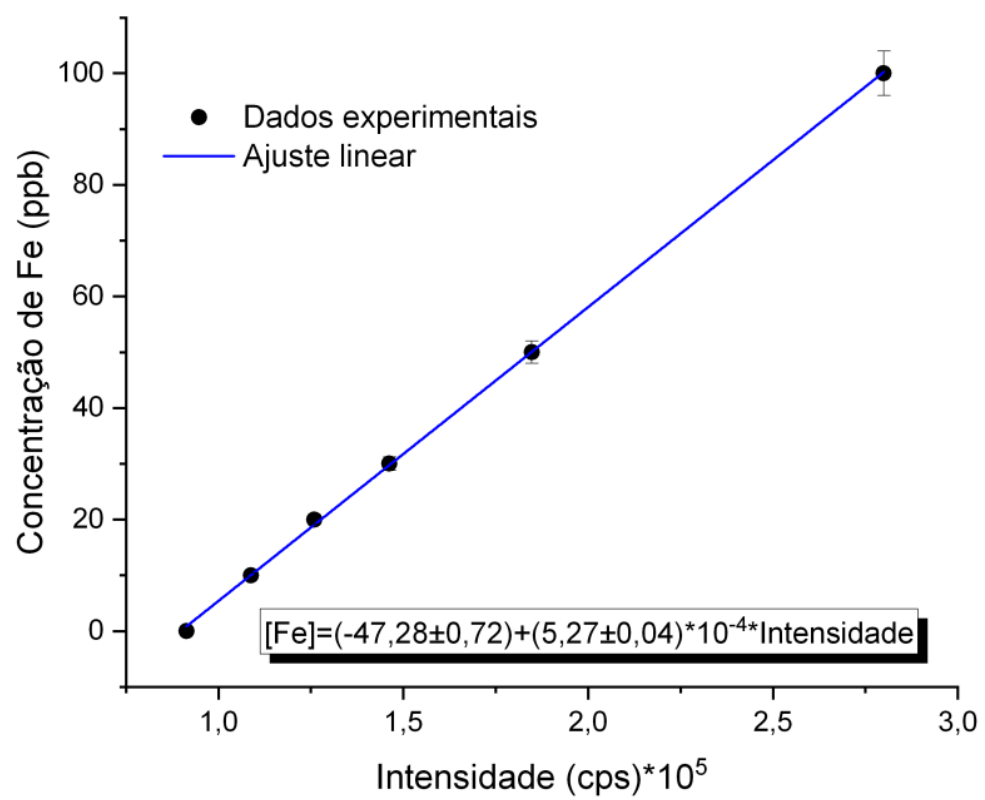

Figura 35. Curva de calibração de espectrometria de massa por plasma indutivamente acoplado a partir de concentrações conhecidas de nanopartículas multimodais

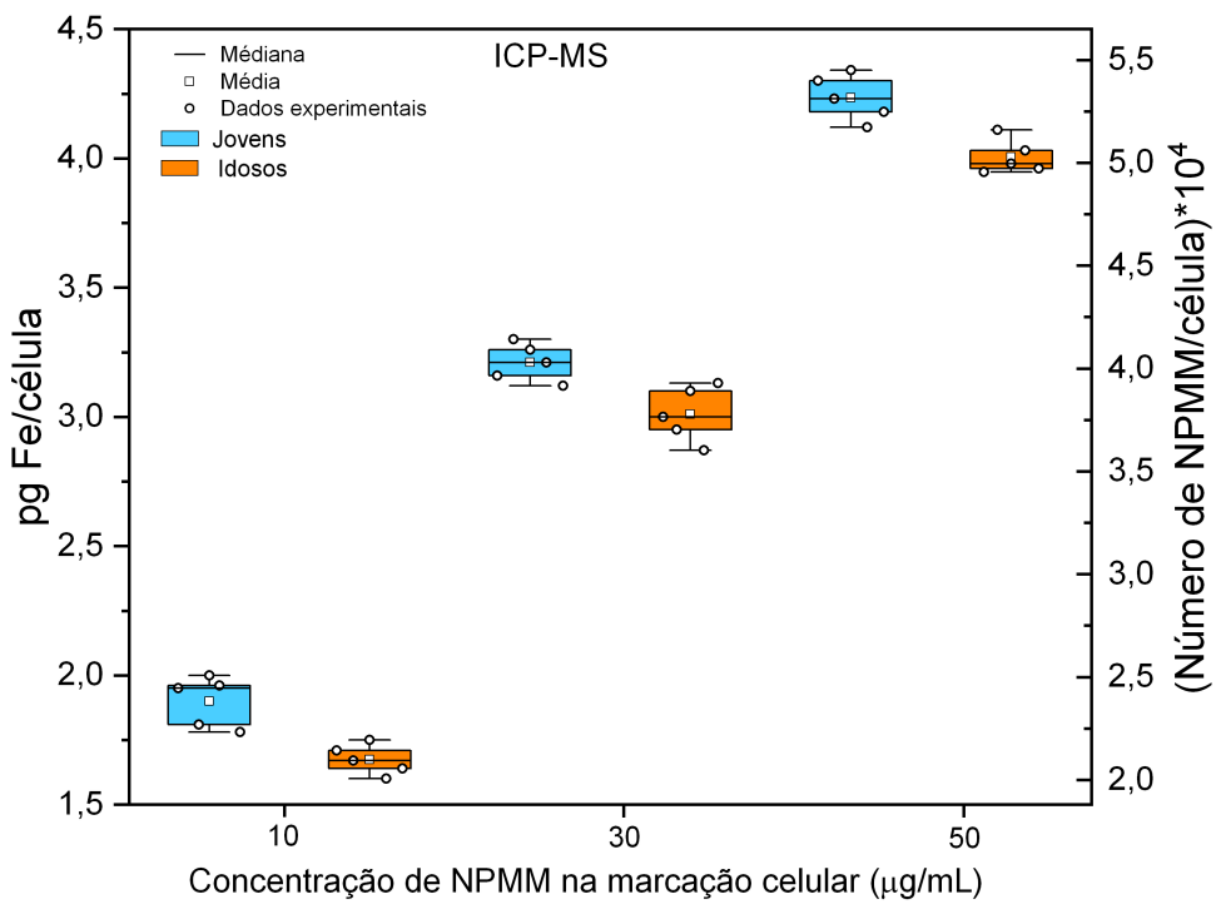

Figura 36. Quantificação pela técnica de espectrometria de massa por plasma indutivamente acoplado da internalização de nanopartículas multimodais/células mononucleares da medula óssea após marcação nas concentrações de 10, 30 e $50 \mu \mathrm{g} \mathrm{Fe} / \mathrm{mL}$ comparando as células mononucleares da medula óssea de camundongos jovens e idosos 
Tabela 18. Valores das da quantificação do ferro internalizado nas células mononucleares da medula óssea por espectrometria de massa por plasma indutivamente acoplado de animais jovens e idosos marcadas com nanopartículas multimodais

\begin{tabular}{ccccc}
\hline Animal & $\begin{array}{c}\text { Concentração } \\
(\boldsymbol{\mu g} \text { NPMM/mL) }\end{array}$ & $\begin{array}{c}\mathbf{p g} \text { Fe/Célula } \\
(\text { Média } \pm \text { DP) }\end{array}$ & $\begin{array}{c}\text { № de NPMM/Célula*10 } \\
(\text { Média } \pm \text { DP) }\end{array}$ & $\mathbf{n}$ \\
\hline Jovens & 10 & $1,90 \pm 0,10$ & $2,39 \pm 0,12$ & 5 \\
Idosos & 10 & $1,67 \pm 0,06$ & $2,10 \pm 0,74$ & 5 \\
Jovens & 30 & $3,21 \pm 0,07$ & $4,03 \pm 0,93$ & 5 \\
Idosos & 30 & $3,01 \pm 0,10$ & $3,78 \pm 0,13$ & 5 \\
Jovens & 50 & $4,23 \pm 0,09$ & $5,32 \pm 0,11$ & 5 \\
Idosos & 50 & $4,00 \pm 0,07$ & $5,03 \pm 0,81$ & 5 \\
\hline
\end{tabular}

NPMM: nanopartículas multimodais; CMN-MO: células mononucleares da medula óssea; ICP-MS: espectrometria de massa por plasma indutivamente acoplado.

Os dados da quantificação de ferro internalizada nas CMN-MO avaliados por ICP-MS foram analisados quanto à diferença na concentração de ferro utilizada para a marcação e entre o uso de células de camundongos jovens e idosos, verificamos pelo teste de ANOVA que a quantificação destes fatores tanto em pg $\mathrm{Fe} / c e ́ l u l a$ quanto por número de NPMM/célula apresentou diferença significativa $(p<0,001)$, mostrado na tabela 19 e na análise de post hoc (Tabela 20) foi verificado que todas as comparações tiveram diferença significativa $(p<0,01)$, sendo relevante que a quantificação de ferro foi diferente entre os grupos (jovens e idosos) para a mesma concentração, como também para o mesmo grupo com diferentes concentrações (10, 30 e $50 \mu \mathrm{g} \mathrm{Fe} / \mathrm{mL}$ ).

Tabela 19. ANOVA da quantificação do ferro internalizado nas células mononucleares da medula óssea por espectrometria de massa por plasma indutivamente acoplado

\begin{tabular}{ccccccc}
\hline Internalização & $\begin{array}{c}\text { Fonte de } \\
\text { Variação }\end{array}$ & $\begin{array}{c}\text { Soma dos } \\
\text { quadrados }\end{array}$ & $\begin{array}{c}\text { Graus de } \\
\text { liberdade }\end{array}$ & $\begin{array}{c}\text { Quadrado } \\
\text { médio }\end{array}$ & F & Valor-p \\
\hline pg Fe/Células & Aplicações & 27,73 & 5 & 5,55 & 790,89 & $<0,001$ \\
& Residual & 0,17 & 24 & 0,01 & & \\
no de & Aplicações & $4,36 \times 10^{9}$ & 5 & $8,75 \times 10^{8}$ & 810,15 & $<0,001$ \\
NPMM/Células & Residual & $2,59 \times 10^{7}$ & 24 & $1,08 \times 10^{6}$ & & \\
\hline
\end{tabular}

NPMM: nanopartículas multimodais; CMN-MO: células mononucleares da medula óssea; ICP-MS: espectrometria de massa por plasma indutivamente acoplado. 
Tabela 20. Teste de post hoc da quantificação do ferro internalizado nas células mononucleares da medula óssea por espectrometria de massa por plasma indutivamente acoplado

\begin{tabular}{|c|c|c|c|c|c|}
\hline \multicolumn{2}{|c|}{ Grupos } & \multirow{2}{*}{$\begin{array}{c}\begin{array}{c}\text { Diferença } \\
\text { da média }\end{array} \\
0,23\end{array}$} & \multirow{2}{*}{$\begin{array}{c}\text { Erro padrão } \\
0,05\end{array}$} & \multirow{2}{*}{$\frac{\mathbf{t}}{4,277}$} & \multirow{2}{*}{$\frac{\text { Valor-p }}{0,003}$} \\
\hline c10_jovens & c10_idosos & & & & \\
\hline & c30_jovens & $-1,31$ & 0,05 & $-24,73$ & $<, 001$ \\
\hline & c30_idosos & $-1,11$ & 0,05 & $-20,95$ & $<, 001$ \\
\hline & c50_jovens & $-2,33$ & 0,05 & $-44,07$ & $<, 001$ \\
\hline & c50_idosos & $-2,10$ & 0,05 & $-39,75$ & $<, 001$ \\
\hline \multirow[t]{4}{*}{ c10_idosos } & c30_jovens & $-1,54$ & 0,05 & $-29,00$ & $<, 001$ \\
\hline & c30_idosos & $-1,34$ & 0,05 & $-25,22$ & $<, 001$ \\
\hline & c50_jovens & $-2,56$ & 0,05 & $-48,33$ & $<, 001$ \\
\hline & c50_idosos & $-2,33$ & 0,05 & $-44,02$ & $<, 001$ \\
\hline \multirow[t]{3}{*}{ c30_jovens } & c30_idosos & 0,20 & 0,05 & 3,77 & 0,010 \\
\hline & c50_jovens & $-1,02$ & 0,05 & $-19,33$ & $<, 001$ \\
\hline & c50_idosos & $-0,79$ & 0,05 & $-15,02$ & $<, 001$ \\
\hline \multirow[t]{2}{*}{ c30_idosos } & c50_jovens & $-1,22$ & 0,05 & $-23,11$ & $<, 001$ \\
\hline & c50_idosos & $-0,99$ & 0,05 & $-18,80$ & $<, 001$ \\
\hline c50_jovens & c50_idosos & 0,23 & 0,05 & 4,31 & 0,003 \\
\hline
\end{tabular}

NPMM: nanopartículas multimodais; CMN-MO: células mononucleares da medula óssea; ICP-MS: espectrometria de massa por plasma indutivamente acoplado.

Para uma melhor visualização da quantificação de ferro internalizado (pg Fe/célula e número de NPMM/células) nas CMN-MO pelas técnicas NIRF, ICP-MS e IRM os dados são mostrados na tabela 21, organizados por grupos jovens e idosos e as concentrações de NPMM utilizadas na marcação celular.

Tabela 21. Comparação da massa de ferro e número de nanopartículas multimodais internalizadas por células mononucleares da medula óssea mediante as técnicas de fluorescência no infravermelho próximo, espectrometria de massa por plasma indutivamente acoplado e imagem de ressonância magnética, nas concentrações de 10, 30 e $50 \mu \mathrm{g}$ de nanopartículas multimodais $/ \mathrm{mL}$

\begin{tabular}{|c|c|c|c|c|c|c|c|}
\hline \multirow[b]{2}{*}{$\begin{array}{c}{[\mathrm{Fe}]} \\
(\mu \mathrm{g} / \mathrm{mL})\end{array}$} & \multirow[b]{2}{*}{ Idade } & \multicolumn{2}{|c|}{ NIRF } & \multicolumn{2}{|c|}{ ICP-MS } & \multicolumn{2}{|c|}{ IRM } \\
\hline & & $\begin{array}{c}\text { Massa } \\
\text { (pg Fe/célula) }\end{array}$ & $\begin{array}{l}N^{\circ} \text { de NPMM } \\
{ }^{*} 10^{4} / \text { células }\end{array}$ & $\begin{array}{c}\text { Massa } \\
\text { (pg Fe/célula) }\end{array}$ & $\begin{array}{l}N^{\circ} \text { de NPMM } \\
{ }^{*} 10^{4} / \text { células }\end{array}$ & $\begin{array}{c}\text { Massa } \\
\text { (pg Fe/célula) }\end{array}$ & $\begin{array}{c}N^{\circ} \text { de } \\
\text { NPMM } \\
* 10^{4} / \text { células }\end{array}$ \\
\hline \multirow{2}{*}{10} & Jovens & $2,27 \pm 0,09$ & $2,85 \pm 0,11$ & $1,90 \pm 0,10$ & $2,39 \pm 0,12$ & - & - \\
\hline & Idosos & $2,07 \pm 0,07$ & $2,61 \pm 0,08$ & $1,67 \pm 0,06$ & $2,10 \pm 0,74$ & - & - \\
\hline \multirow{2}{*}{30} & Jovens & $3,06 \pm 0,12$ & $3,85 \pm 0,15$ & $3,21 \pm 0,07$ & $4,03 \pm 0,93$ & - & - \\
\hline & Idosos & $3,02 \pm 0,09$ & $3,79 \pm 0,11$ & $3,01 \pm 0,10$ & $3,78 \pm 0,13$ & - & - \\
\hline \multirow{2}{*}{50} & Jovens & $3,98 \pm 0,16$ & $5,00 \pm 0,20$ & $4,23 \pm 0,09$ & $5,32 \pm 0,11$ & $3,13 \pm 0,24$ & $3,93 \pm 0,30$ \\
\hline & Idosos & $3,98 \pm 0,14$ & $5,00 \pm 0,18$ & $4,00 \pm 0,07$ & $5,03 \pm 0,81$ & $3,08 \pm 0,17$ & $3,87 \pm 0,21$ \\
\hline
\end{tabular}

NPMM: nanopartículas multimodais; CMN-MO: células mononucleares da medula óssea; NIRF: fluorescência no infravermelho próximo; ICP-MS: espectrometria de massa por plasma indutivamente acoplado; IRM: imagem de ressonância magnética. 


\subsection{Estudo in vivo}

\subsubsection{Avaliação da curva de dose letal}

Para estabelecer a dose letal mínima de radiação no condicionamento dos animais para realização do TCTH foram irradiados 12 camundongos C57BL/6 com diferentes doses de radiação (5, 7, 9 e 11Gy) e avaliamos a sobrevida dos animais por 30 dias. Como pode ser visualizado na figura 37 , os animais irradiados com as doses de 5 e 7Gy tiveram sobrevida superior aos 30 dias de análise. Já os camundongos irradiados com 9Gy, no dia 12 após a $\mathrm{ICl}$, foi observado que um dos animais apresentava desidratação severa, perda superior a $20 \%$ do peso inicial, mucosas hipocoradas e mobilidade reduzida, sendo realizado a eutanásia deste animal para que fosse evitado maior sofrimento, o mesmo aconteceu com os outros 2 camundongos deste grupo, irradiados com 9Gy, no dia 14 após a ICI. Os animais irradiados com 11Gy foram encontrados mortos no $11^{\circ}$ após a ICI.

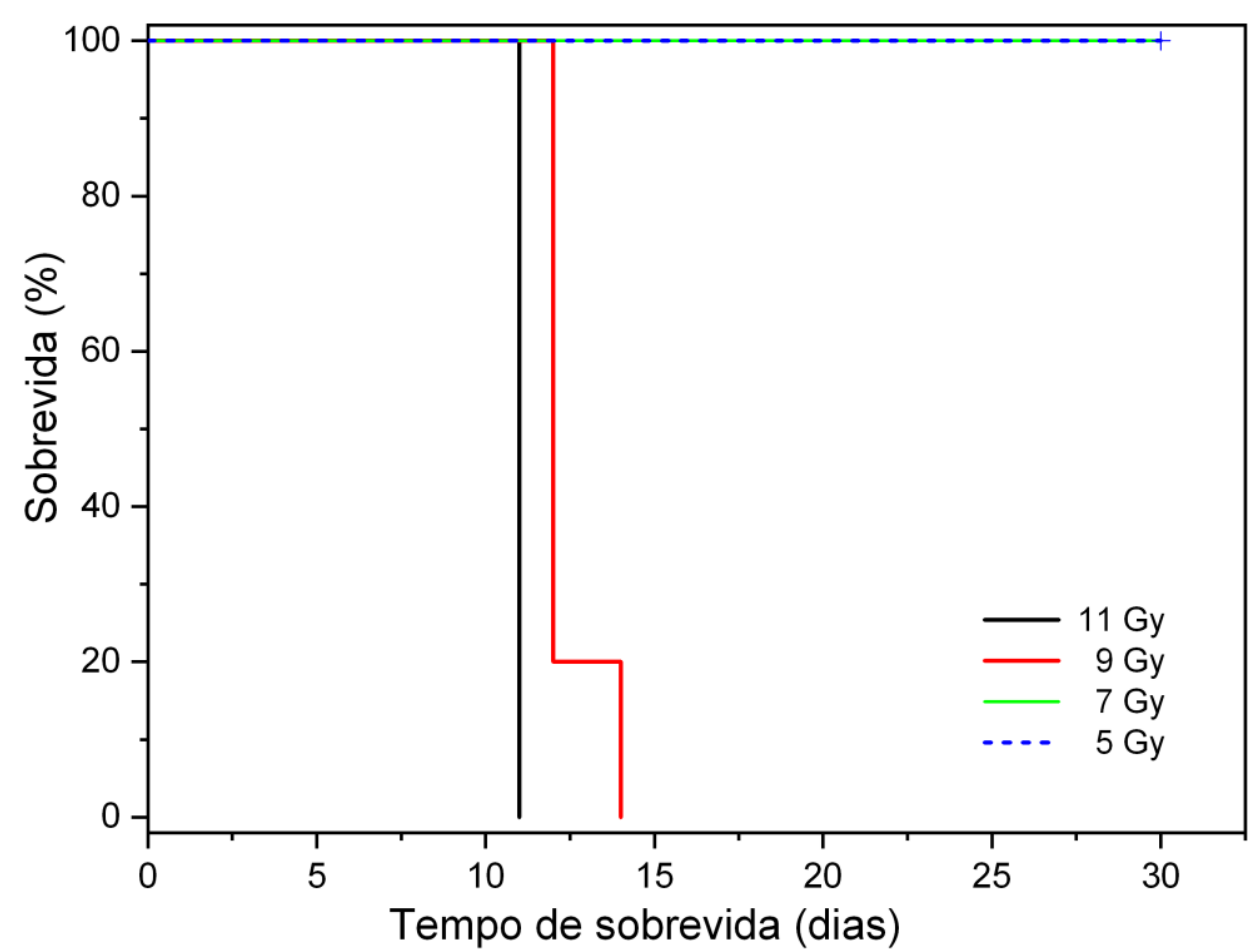

Figura 37. Análise de sobrevida realizada por 30 dias em animais que receberam irradiação de corpo inteiro

Os resultados indicaram que a dose letal mínima para o condicionamento dos animais para realização do TMO foi de 9Gy. 


\subsubsection{Avaliação da migração das células mononucleares da medula óssea de camundongos jovens e idosos}

\subsubsection{Avaliação da migração por imagem de bioluminescência}

As imagens de BLM dos animais receptores das células de doadores jovens e idosos foram adquiridas ao longo de 4 meses (120 dias), com imagens sendo realizadas semanalmente durante o primeiro mês e a cada 15 dias aproximadamente nos meses seguintes. As figuras 38 e 39 mostram que no 4ํㅜ dia não foi possível obter sinal de BLM das células transplantadas, já no 11ำ dia foi observado um sinal de BLM nas 4 posições analisadas, esse sinal estava presente principalmente no lado esquerdo dos animais, provavelmente em função da presença do baço na região. Assim também foi possível verificar sinais presentes na região da coluna espinhal e tibiofemoral. Com o avanço dos dias de análise o sinal se tornou mais intenso, tendo seu pico máximo de intensidade em 30 dias para os receptores de células idosas $\left(7,88 \pm 2,61 \times 10^{8}\right.$ fótons/s) e em 35 dias para os receptores de células jovens $\left(10,18 \pm 2,35 \times 10^{8}\right.$ fótons/s), como pode ser visualizado na figura 40 e tabela 22. O sinal de BLM após o máximo pico de intensidade mostrou uma redução acentuada até 85 dias, com os valores de $2,10 \pm 1,19 \times 10^{8}$ fótons/s e $0,96 \pm 0,21 \times 10^{8}$ fótons/s para os receptores de células jovens e idosas respectivamente, se mantendo estável na ordem de aproximadamente $10^{8}$ fótons/s até o fim da análise em 120 dias, indicando a presença de células doadoras tanto de animais jovens como idosos por todo o período de avaliação. 

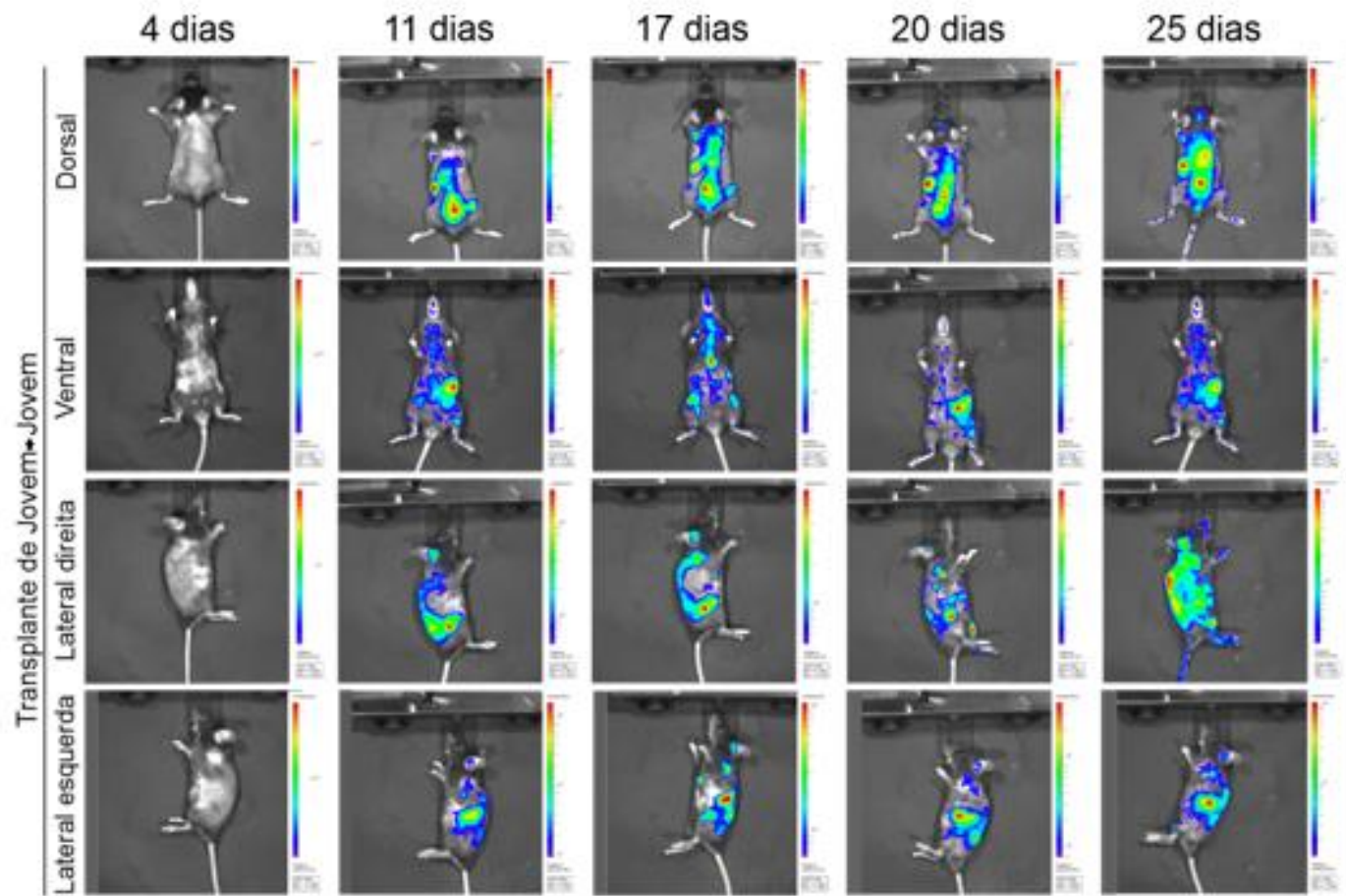

30 dias
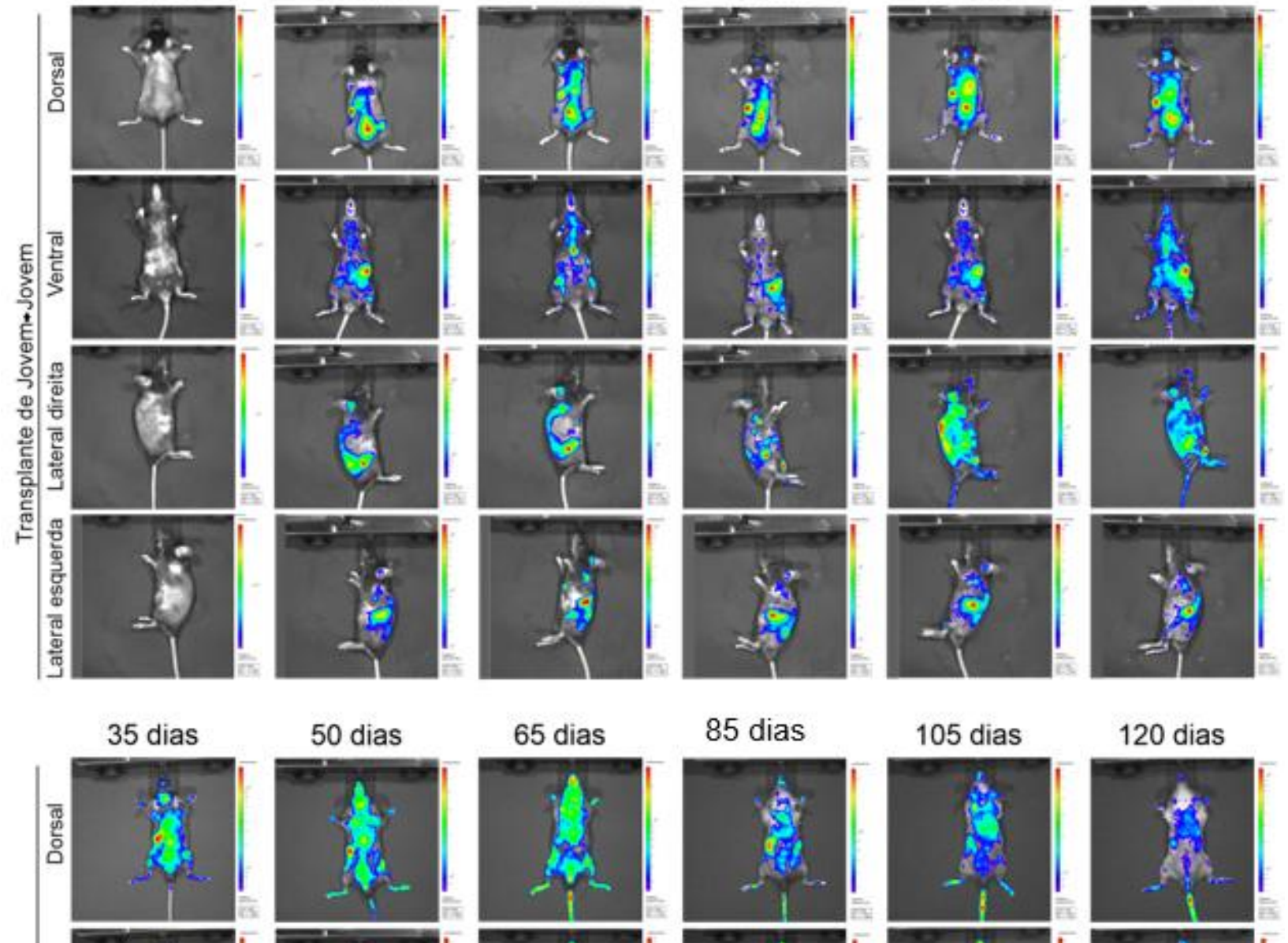

120 dias
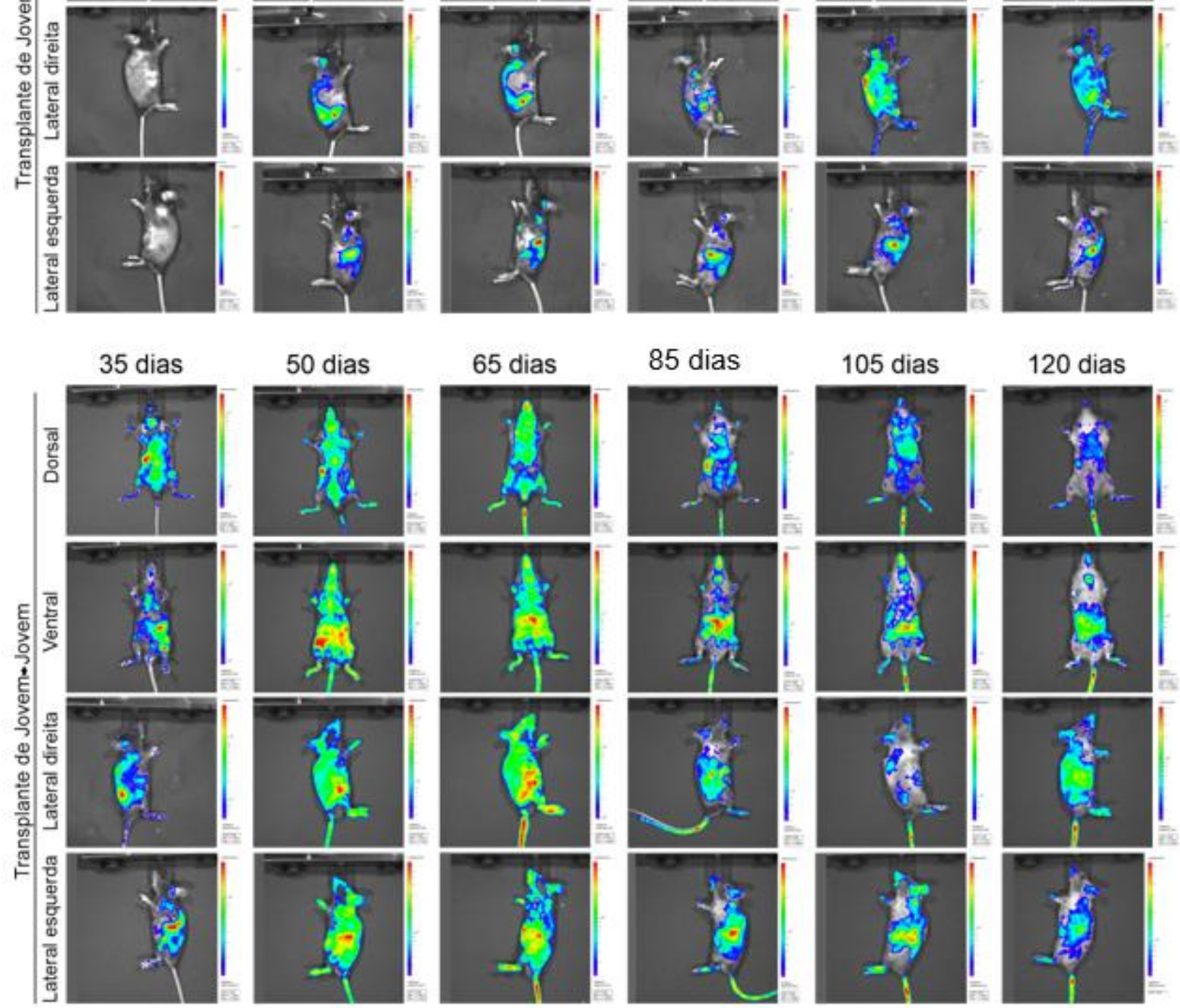

Figura 38. Rastreamento das células transplantadas de doadores jovens em receptores jovens por um período de 120 dias por imagem de bioluminescência 

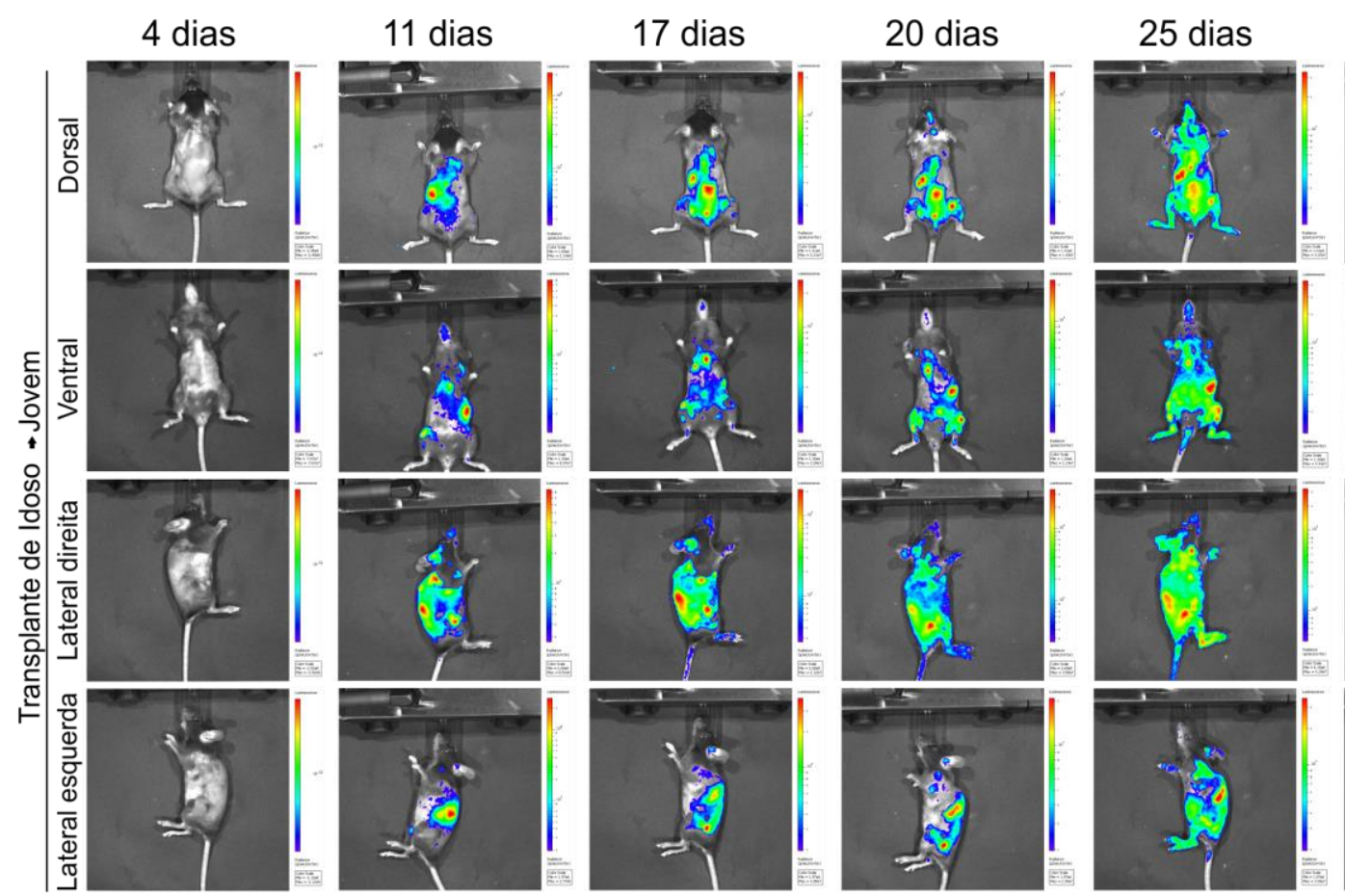

30 dias
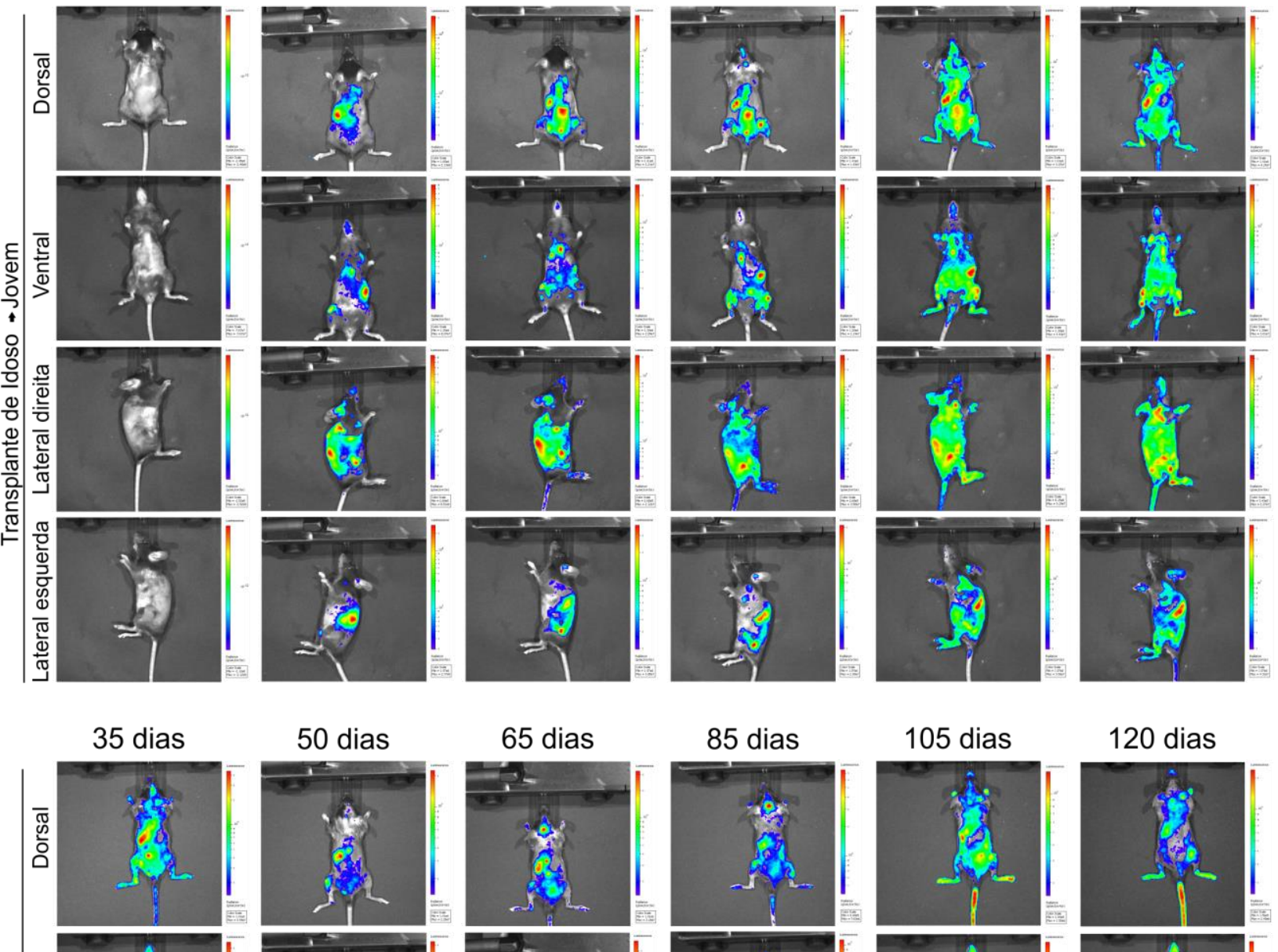

65 dias

\section{5 dias}
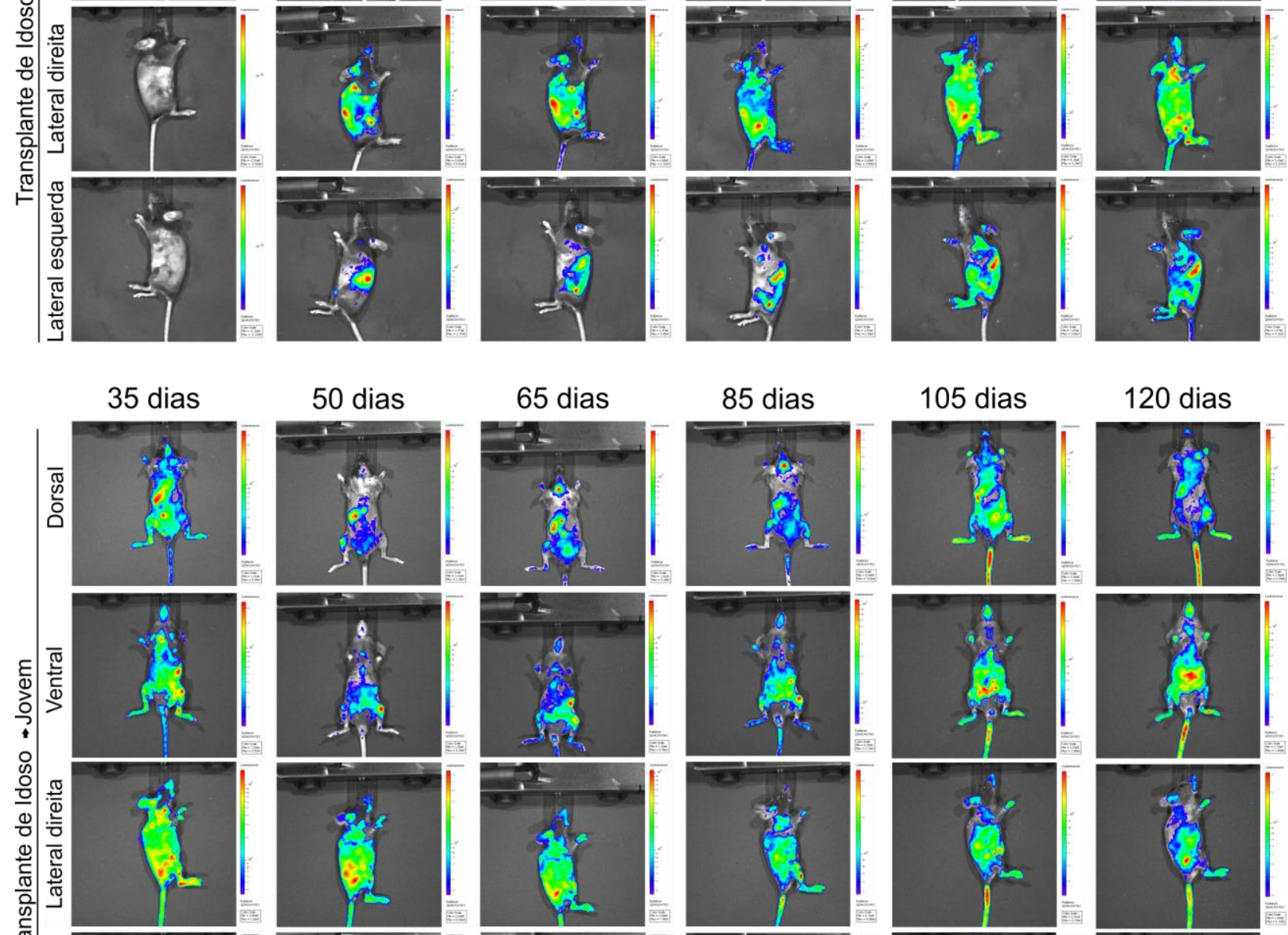

120 dias
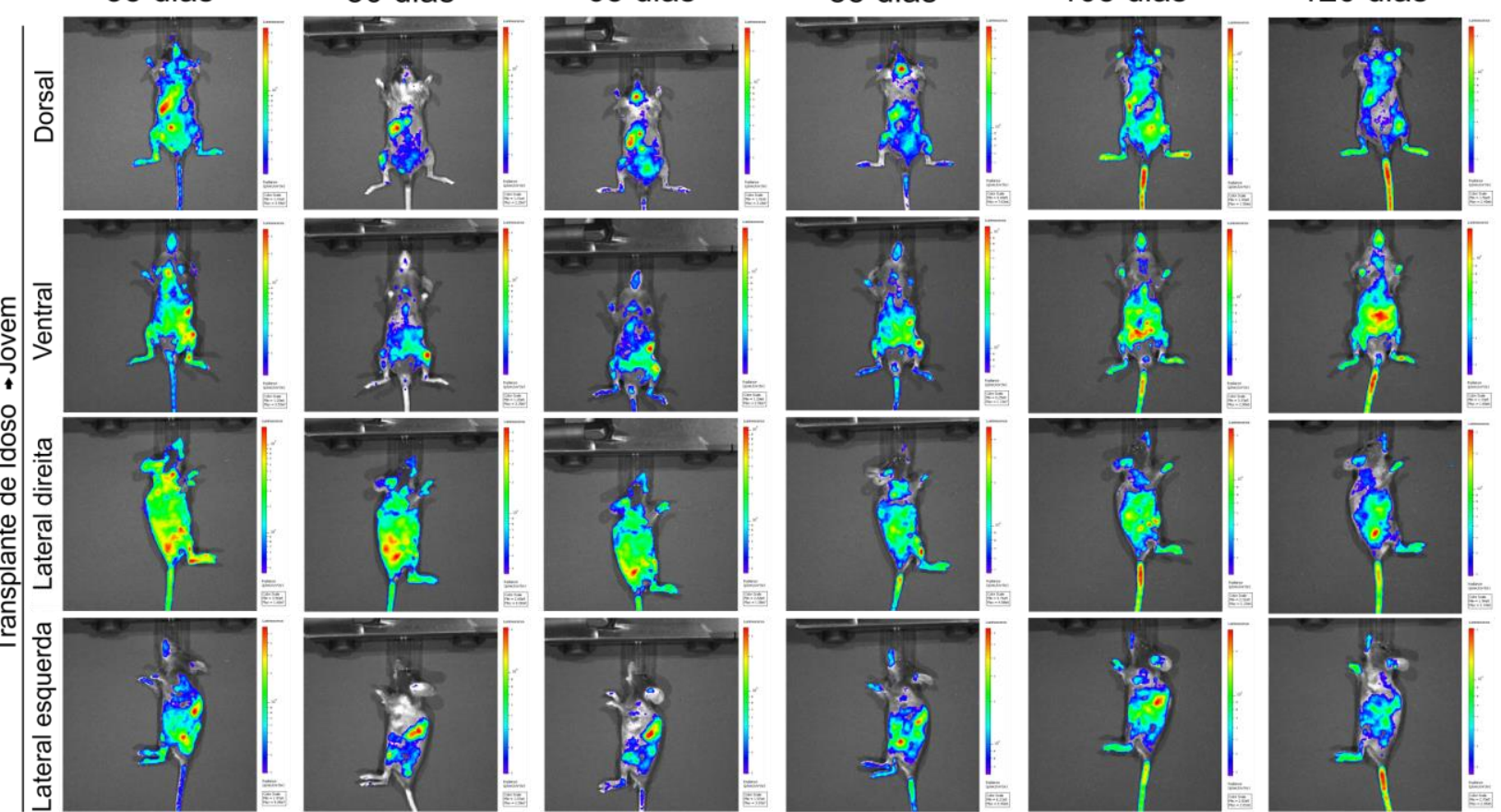

Figura 39. Rastreamento das células transplantadas de doadores idosos em receptores jovens por um período de 120 dias por imagem de bioluminescência 


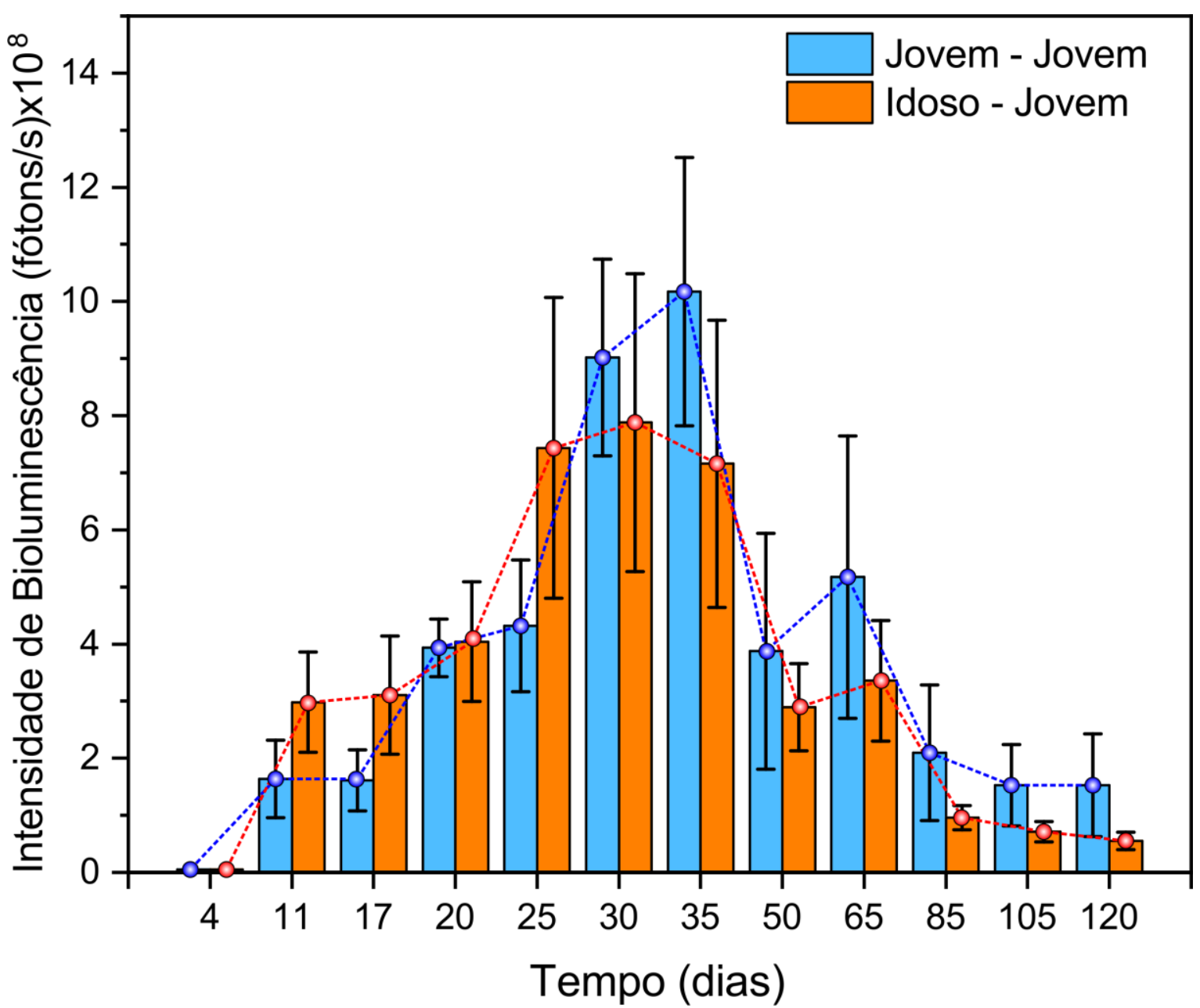

Figura 40. Intensidade de sinal de bioluminescência de animais que receberam células de doadores jovens e idosos ao longo de 120 dias

Tabela 22. Valores de intensidade de sinal de bioluminescência de animais que receberam células de doadores jovens e idosos ao longo de 120 dias

\begin{tabular}{|c|c|c|}
\hline \multirow{2}{*}{$\begin{array}{c}\text { Tempo de avaliação } \\
\text { (dias) }\end{array}$} & \multicolumn{2}{|c|}{ Média \pm desvio padrão da Intensidade de BLM (fótons/s) x10 } \\
\hline & Jovem $\rightarrow$ Jovem & Idoso $\rightarrow$ Jovem \\
\hline 4 & 0 & 0 \\
\hline 11 & $1,64 \pm 0,68$ & $2,98 \pm 0,88$ \\
\hline 17 & $1,61 \pm 0,53$ & $3,11 \pm 1,04$ \\
\hline 20 & $3,93 \pm 0,50$ & $4,04 \pm 1,05$ \\
\hline 25 & $4,32 \pm 1,15$ & $7,44 \pm 2,64$ \\
\hline 30 & $9,02 \pm 1,72$ & $7,88 \pm 2,61$ \\
\hline 35 & $10,18 \pm 2,35$ & $7,16 \pm 2,51$ \\
\hline 50 & $3,87 \pm 2,07$ & $2,89 \pm 0,76$ \\
\hline 65 & $5,17 \pm 2,47$ & $3,36 \pm 1,05$ \\
\hline 85 & $2,10 \pm 1,19$ & $0,96 \pm 0,21$ \\
\hline 105 & $1,53 \pm 0,71$ & $0,71 \pm 0,18$ \\
\hline 120 & $1,53 \pm 0,90$ & $0,55 \pm 0,16$ \\
\hline
\end{tabular}

BLM: bioluminescência. 
Após 120 dias de avaliação por imagem de BLM in vivo, os animais foram eutanasiados e os órgãos (cérebro, pulmão, coração, baço, fígado, rins, fêmur, tíbia e coluna espinhal) foram coletados para realização de imagens de BLM ex vivo (Figura 41 A, C, D e F). A figura 41 A e C mostram imagens ex vivo de BLM dos órgãos coletados de um receptor de células jovens, com destaque para baço, pulmão, fêmur, tíbia e coluna espinhal, onde foi possível observar o sinal BLM, sobretudo no baço, região de maior intensidade de sinal, o mesmo padrão pode ser visualizado na figura $41 \mathrm{D}$ e $\mathrm{F}$ de um animal que recebeu células provenientes de doador idoso. Já a figura $41 \mathrm{~B}$ e $\mathrm{E}$, representam o sinal de BLM encontrado na análise in vivo antes da retirada dos órgãos, podendo assim mostrar a correlação dos sinais in vivo e ex vivo, com destaque para as regiões com maior intensidade de BLM visualizadas.
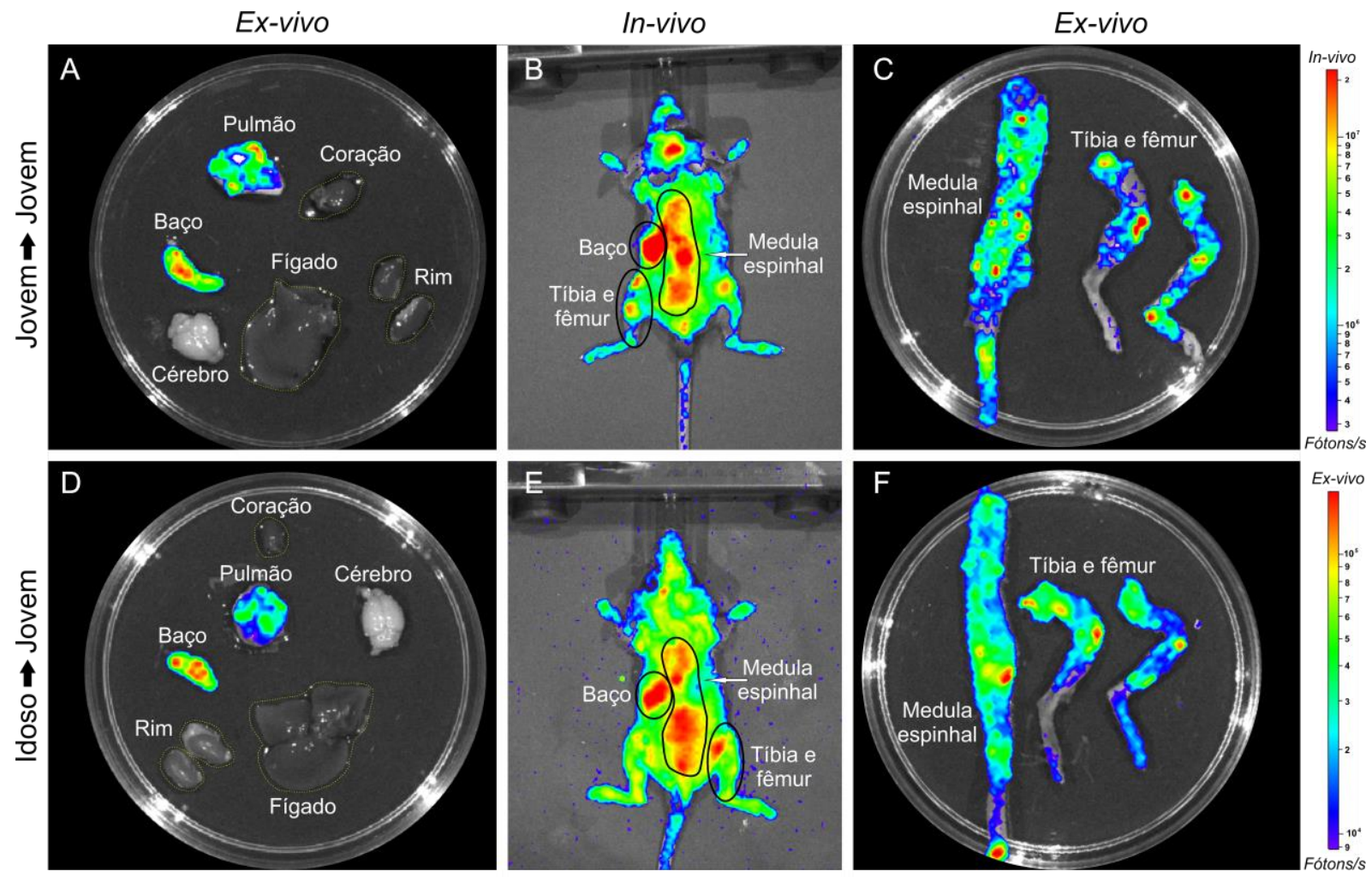

Figura 41. Imagem de bioluminescência ex vivo dos principais órgãos de animais receptores de células de doadores jovens e idoso após 120 dias do transplante de medula óssea 


\subsubsection{Avaliação da migração por imagem de fluorescência no infravermelho próximo}

O homing das CMN-MO de doadores jovens e idosos marcadas com NPMM foi avaliado in vivo por NIRF 24 horas após o transplante, foram obtidas imagens nos planos dorsal e ventral, onde foi possível observar a distribuição das células marcadas por todo o animal com destaque para a região da coluna espinhal, como também na região abdominal, possivelmente no fígado (Figura 42). Para confirmar a localização do sinal de NIRF os animais foram eutanasiados após a aquisição de imagens in vivo e então foram realizadas imagens ex vivo dos principais órgãos, evidenciando um sinal de NIRF em praticamente todos os órgãos analisados (pulmão, coração, baço, fígado, rins, coluna espinhal, tíbia e fêmur), com destaque para os órgãos hematopoiéticos como baço e medula óssea em receptores de células jovens (Figura 42 E-j, I-j e J-j) e idosos (Figura 42 E-i, I-i e J-i). Entretanto, não foi possível evidenciar diferenças de sinal entre os animais que receberam células de doadores jovens e idosos. 

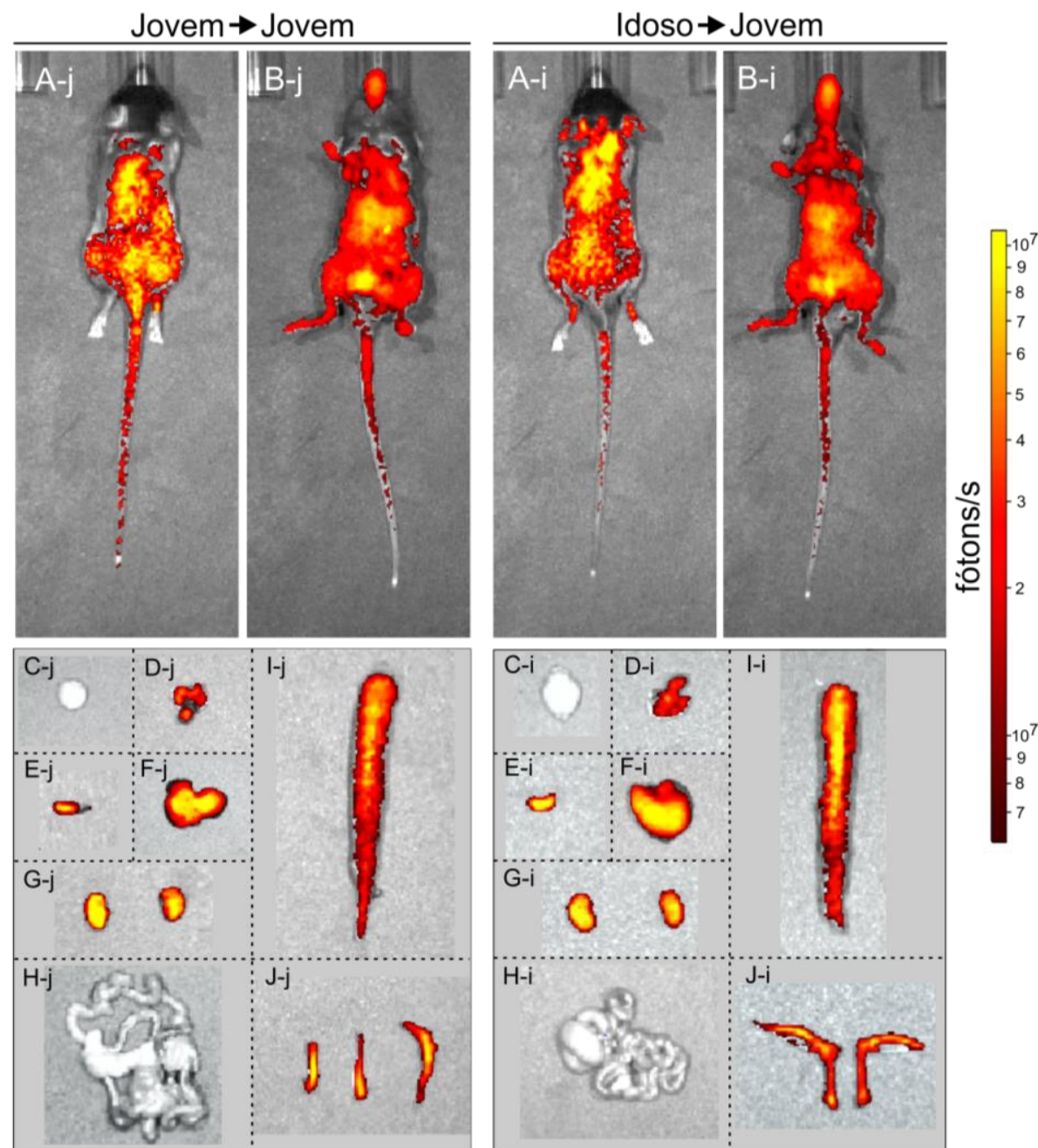

A-j: Imagem de fluorescência no infravermelho próximo na posição dorsal de um receptor de células jovens marcadas com nanopartículas multimodais. B-j: Imagem de fluorescência no infravermelho próximo na posição ventral de um receptor de células jovens marcadas com nanopartículas multimodais. A-i: Imagem de fluorescência no infravermelho próximo na posição dorsal de um receptor de células idosas marcadas com nanopartículas multimodais. B-i: Imagem de fluorescência no infravermelho próximo na posição ventral de um receptor de células idosas marcadas com nanopartículas multimodais. C-j: Cérebro. D-j: Pulmão e coração. E-j: Baço. F-j: Fígado. G-j: Rins. H-j: Intestino. I-j: Coluna espinhal. J-j: Tíbias e fêmures. C-i: Cérebro. D-i: Pulmão e coração. E-i: Baço. F-i: Fígado. G-i: Rins. H-i: Intestino. I-i: Coluna espinhal. J-i: Tíbias e fêmures.

Figura 42. Imagem in vivo e ex vivo de fluorescência no infravermelho próximo 24 após o transplante de células provenientes de animais jovens e idosos

\subsubsection{Avaliação da migração por análise histológica}

Após a administração de CMN-MO por via intravenosa, os animais foram eutanasiados e os principais órgãos foram coletados para análise histológica. $\mathrm{Na}$ figura 43, podemos observar que em todos os órgãos, exceto o cérebro (Figura 43 C14) foi possível identificar áreas do tecido coradas em azul, devido a presença do ferro das NPMM, sendo a coloração mais prevalente em órgãos hematopoiéticos com baço (Figura 43 B1-4) e MO (Figura 43 H1-4). 


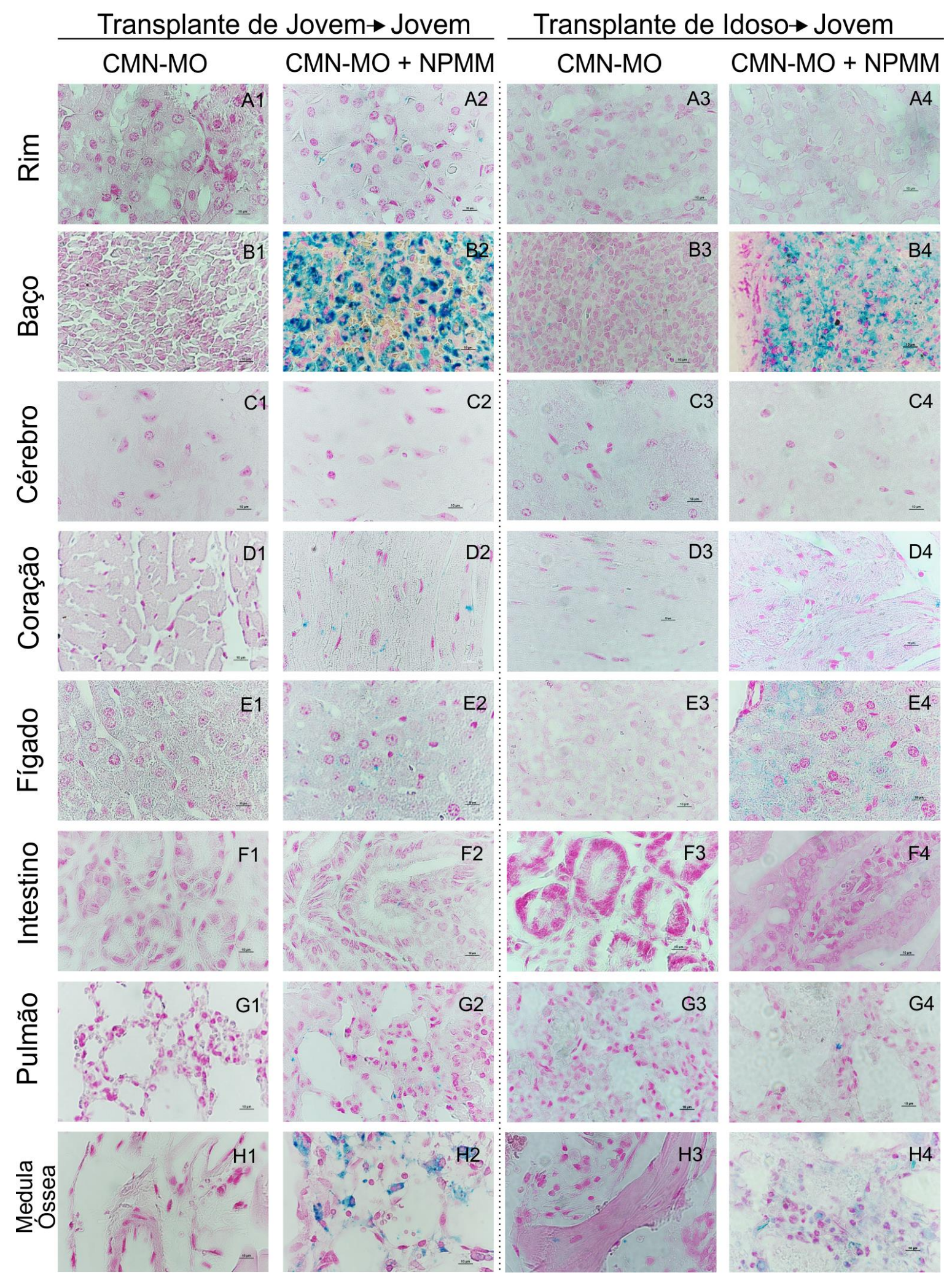

A1-4: Rim. B1-4: Baço. C1-4: Cérebro. D1-4: Coração. E1-4: Fígado. F1-4: Intestino. G1-4: Pulmão. H1-4: Medula óssea.

Figura 43. Análise histológica de tecidos de animais submetidos ao transplante de medula óssea cortados com $5 \mu \mathrm{m}$ e corados com azul da Prússia e nuclear fast red no aumento de 100x 


\subsubsection{Avaliação da reconstituição hematológica}

A avaliação da reconstituição hematológica foi realizada por hemograma automatizado após 15, 30, 60, 90 e 120 dias da realização do transplante, os resultados podem ser visualizados na figura 44 .

A figura 44-A indica que após 120 dias de análise os leucócitos dos animais que receberam células de doadores jovens e de idosos chegaram a níveis semelhantes aos dos controles. Entretanto, a curva de resposta da produção de leucócitos foi mais lenta nos animais que receberam células de doadores idosos. Já os granulócitos (Figura 44-B) tiveram recuperação semelhante em 15 dias após o transplante, com um aumento acentuado nos animais que receberam células de doadores jovens na análise de 30 dias, que se inverteu com o passar do tempo, tendo maior presença de granulócitos os receptores de células idosas ao final da análise dos 120 dias.

A partir do dia 30, os dois grupos tiveram um aumento na quantidade de leucócitos e hemácias circulantes, sendo que camundongos que receberam células jovens tiveram um número maior de leucócitos que os camundongos que receberam células idosas. Também foi observado que na análise do dia 60, que o enxerto jovem recuperou o número normal de linfócitos com redução no número de granulócitos circulantes, já no enxerto de células idosas não houve aumento da produção linfocítica e uma menor redução da produção de granulocítica indicando uma hematopoese inclinada em direção à linhagem mieloide, o que se manteve até o final da análise com linfócitos representando a maior população entre os leucócitos no enxerto jovem, já no enxerto idoso os granulócitos representaram a maioria dos leucócitos circulantes (Figura 44-B e D). A análise da recuperação dos linfócitos se mostrou mais lenta quando comparada aos granulócitos, atingindo valores semelhantes ao controle apenas em receptores de células jovens. A recuperação de monócitos nos dois grupos retornou padrões semelhantes, mas sem atingir valores próximos aos controles em 120 dias (Figura 44-C). Hemácias e plaquetas mostraram padrões de recuperação semelhante aos controles na análise de 30 dias e se mantiveram iguais até o fim da análise (Figura 44-E e F). 

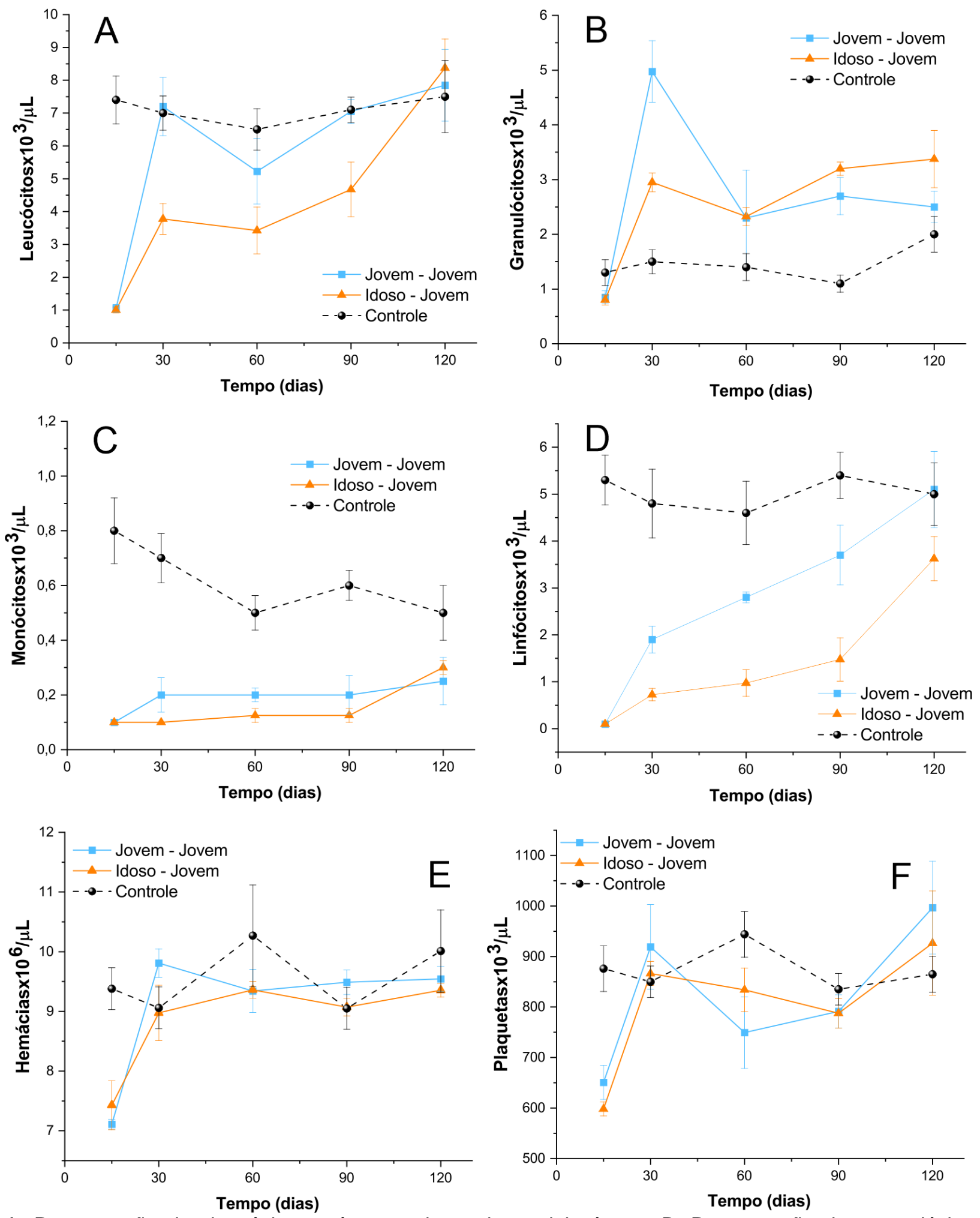

A: Recuperação dos leucócitos após transplante de medula óssea. B: Recuperação dos granulócitos após transplante de medula óssea. C: Recuperação dos monócitos após transplante de medula óssea. D: Recuperação dos linfócitos após transplante de medula óssea. E: Recuperação das hemácias após transplante de medula óssea. F: Recuperação das plaquetas após transplante de medula óssea.

Figura 44. Análise por hemograma da reconstituição hematopoiética dos animais receptores de células de doadores jovens e idosos por 120 dias 


\subsubsection{Quantificação de células linhagem- Sca-1+ c-Kit+ na medula receptora}

A quantificação de células LKS da medula receptora por citometria de fluxo foi realizada após 120 dias do TMO, na figura 45 foi possível observar que após a análise de tamanho (FSC) e viabilidade (7AAD), foi realizada a análise de marcadores de linhagem e CD177, que não mostrou diferença na população linhagemCD177+ das células coletadas da medula de receptores de células jovens $(6,1 \%)$ e idosas (4,7\%). Para identificação das células LKS foi feito primeiramente uma análise de fluorescência menos um (FMO - Fluorescence Minus One), sem o marcador Sca-1 para identificar o limite da população CD177+, a partir disso obtivemos valores de $67,0 \%$ de células LKS dentro da população linhagem- CD177+ em receptores de células jovens e de $70,4 \%$ em receptores de células idosas, como mostrado no gráfico da figura 45.

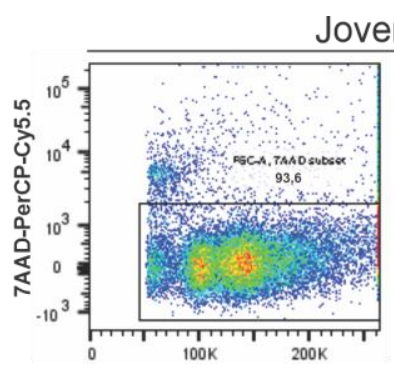

FSC-A
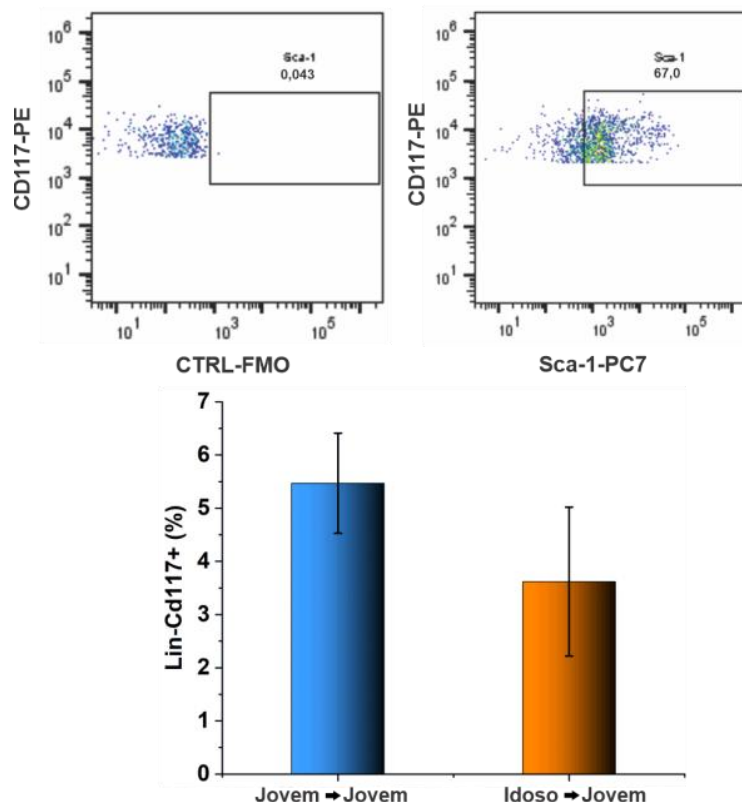

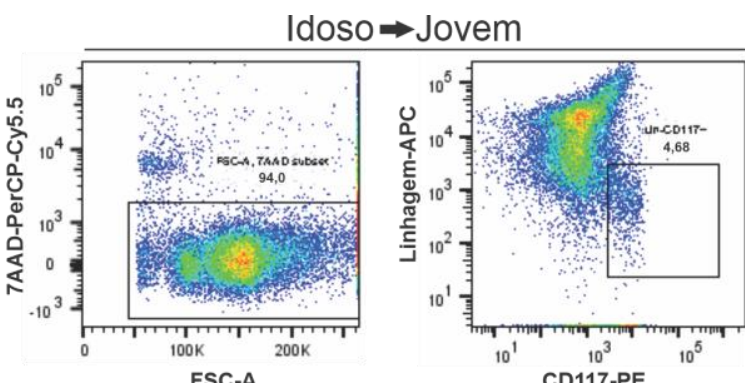

FSC-A
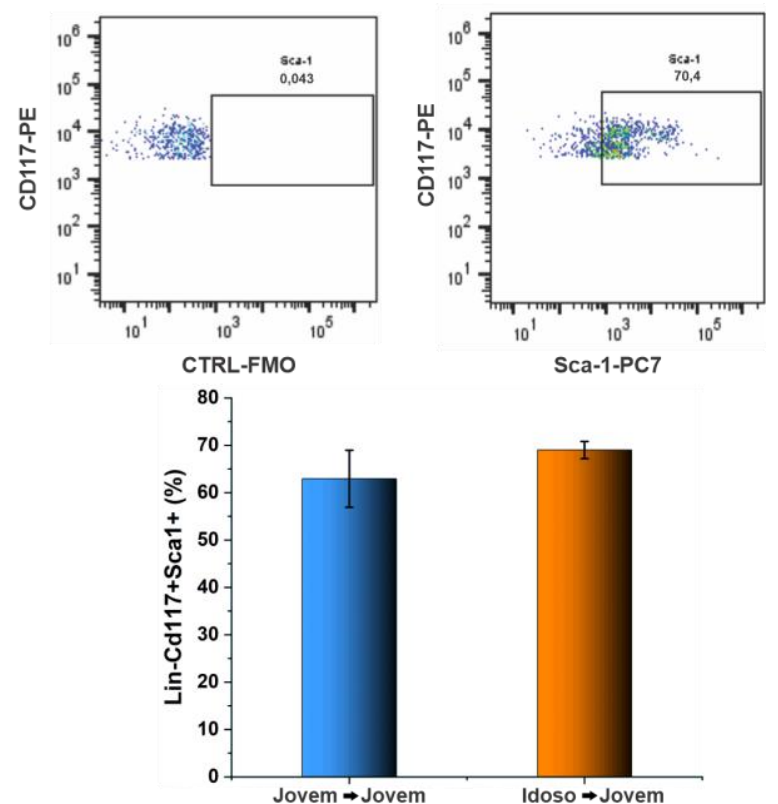

Figura 45. Análise por citometria de fluxo da população de células linhagem- Sca-1+ c-Kit+ presente na medula óssea receptora de células de animais jovens e idosos após 120 dias da realização do transplante de medula óssea 
4 DISCUSSÃO

O TMO é um tratamento consagrado para as patologias do sistema hematopoiético, entretanto, ainda existem desafios para um melhor entendimento sobre a migração das $\mathrm{CTH}$ após a realização do transplante. Um dos principais desafios envolve a falta de dados consistentes sobre o homing das CTH para a MO, como também a sobrevivência das células após sua administração e o processo de enxerto das diferentes populações de células hematopoiéticas em experimentos in vivo, utilizando técnicas não invasivas que permitam uma avaliação temporal em um único animal.

O envelhecimento tem grande influência nessas questões, já é sabido que CTH de animais idosos tem menor capacidade de migrar e enxertar quando comparada a CTH extraídas de camundongos jovens. ${ }^{(37,105)}$ Para buscar um melhor entendimento sobre homing das CTH após o TMO e avaliar a diferença de migração devido a influência do envelhecimento, marcamos as células de camundongos jovens e idosos com NPMM que possuem núcleo de óxido de ferro e dois tipos de fluoróforos com diferentes comprimento de onda em sua superfície (espectro visível e no infra vermelho), além disso, as células foram transduzidas com vetor lentiviral para expressão de luciferase, essa combinação de técnicas permite análises qualitativas e quantitativas tanto in vitro como in vivo. Sendo assim, a escolha do agente de rastreamento, cuidados no isolamento das células e sua marcação antes do transplante, são desafios estudados para potencializar a melhor condição e para que se possa atingir o objetivo da avaliação do homing e enxerto das $\mathrm{CTH}$.

No caso das nanopartículas, para sua utilização como agentes de rastreamento é necessário que elas tenham propriedades físico-químicas adequadas. Essas propriedades contribuem para uma internalização eficiente, mantendo a viabilidade e capacidade de enxertar das $\mathrm{CTH}$, permitindo assim o rastreamento não invasivo das células por técnicas de imagem molecular. ${ }^{(68)}$

As NPMM foram avaliadas quanto as suas propriedades físicoquímicas e pôde ser observado que possuíam um diâmetro hidrodinâmico de $38,2 \mathrm{~nm}$ com um potencial zeta positivo de $34,9 \mathrm{mV}$ (Figura 19), quando analisadas em água, o potencial zeta positivo facilita o processo de internalização das NPMM, devido à carga superficial negativa das $\mathrm{CTH}$ e o processo eletrostático envolvido. ${ }^{(127)}$ Alguns estudos 
utilizaram estratégias com o uso de agentes de transfecção como polibreno, sulfato de protamina e lipofectamina para potencializar a internalização/marcação das nanopartículas nas $\mathrm{CTH} .{ }^{(56-58)}$

A análise do tamanho hidrodinâmico das NPMM em outras condições mostrou uma variação de acordo com o meio em que as nanopartículas estão suspensas, pela ligação a proteínas e lipídios dispersos na solução que levam a formação de uma "coroa" que amplia o seu tamanho, ${ }^{(128,129)}$ nosso trabalho mostrou um aumento de $14 \%$ no diâmetro das NPMM quando elas estão dispersas no meio de cultura (SFEM), utilizado para a marcação das células, também pôde ser observado um aumento do diâmetro hidrodinâmico quando as NPMM estavam suspensas em SFEM na presença de $10 \%$ de SFB, já quando as NPMM estavam suspensas em PBS o diâmetro hidrodinâmico foi inferior ao registrado em água.

Uma vez realizadas as medidas de tamanho hidrodinâmico, as NPMM foram avaliadas quanto a estabilidade do tamanho hidrodinâmico por 4 horas, o mesmo tempo utilizado para marcação de células com NPMM no nosso estudo e em outros estudos identificados. ${ }^{(56-58)}$ Observou-se que o tamanho hidrodinâmico das NPMM se mantém estável ao longo do tempo em todas as condições testadas (Figura 20), um aumento no tamanho hidrodinâmico poderia afetar a capacidade das NPMM internalizarem pela formação de aglomerados de nanopartículas, isso geralmente ocorre em NSOF que não são revestidos e acabam se aglomerando devido à atração magnética, alta energia de superfície e forças de van der Waals. ${ }^{(130)}$

Outro aspecto importante na realização do modelo experimental de TMO é o número limitado de CTH isoladas a partir de um animal, devido ao baixo número de $\mathrm{CTH}$ presentes na $\mathrm{MO}$, o que exigiria um número muito alto de camundongos utilizados como doadores. ${ }^{(7)}$ Para enfrentar este desafio foi analisado o efeito da administração prévia de 5-fluorouracil nos animais doadores antes do isolamento, esta fármaco age na MO induzindo uma hipoplasia temporária, que posteriormente gera um estímulo para que a MO promova um aumento na produção de $\mathrm{CTH}^{(131)}$ Quando isolamos as células com a administração prévia de 5-fluorouracil, encontramos um número maior de células linhagem- tanto em camundongos jovens como em idosos, também foi possível observar que as células LKS de camundongos idosos estão presentes em menor frequência na MO quando comparadas a medula de animais jovens. Essa estratégia potencializa o rastreamento, considerando que para a avaliação da migração das células in vivo de forma não invasiva um dos fatores 
importantes é o número de células administradas. ${ }^{(132,133)}$ Também foi observado que 4 dias após a administração de 5-fluorouracil a população de células linhagem- na MO de camundongos jovens $(59,5 \%)$ era menos frequente do que na $\mathrm{MO}$ de camundongos idosos $(91,6 \%)$, isso se dá pela capacidade de diferenciação reduzida gerada pelo envelhecimento, que acaba retardando a resposta das $\mathrm{CTH}$ frente ao 5 -fluorouracil. ${ }^{(134)}$

A marcação/internalização das CMN-MO de animais jovens e idosos com as NPMM foi realizada somente após a caracterização das propriedades físicoquímicas das NPMM e análise da sua estabilidade nas condições de aplicação in vivo. Geralmente a confirmação da internalização de NSOF em CTH e em outros tipos celulares é realizada pela coloração de azul da Prússia que evidencia as nanopartículas internalizadas em azul. ${ }^{(56,57,77,135)}$ No nosso trabalho podemos corroborar a internalização das nanopartículas por várias técnicas, devido à utilização de uma nanopartícula que apresenta características magnéticas e dupla FL, permitindo verificar a internalização não só por meio da coloração de azul da Prússia, mas também por microscopia de FL, IRM e NIRF.

A avaliação por microscopia de campo claro e FL evidenciou as NPMM na região do citoplasma de células, com alta relação núcleo/citoplasma e na faixa dos $10 \mu \mathrm{m}$ sugestivo para CTH. ${ }^{(136)}$ Para análise por NIRF, utilizamos NPMM nas concentrações de $0,10,30$ e $50 \mu \mathrm{g} / \mathrm{mL}$, sendo obtido um sinal na ordem de $10^{8}$ fótons $/ \mathrm{s}$ para todas as concentrações, com um sinal $\sim 35 \%$ maior na concentração de 50 , quando comparada a $10 \mu \mathrm{g} / \mathrm{mL}$ de NPMM, tanto para células de camundongos jovens quanto para idosos (Figura 29). A viabilidade das células após marcação com NPMM foi avaliada por imagem de BLM nas concentrações citadas anteriormente, sendo que a células marcadas na maior concentração $(50 \mu \mathrm{g} N P M M / m L)$ mostraram viabilidade superior a 95\% (Figura 30), outro estudo que marcou CTH com nanopartículas registrou viabilidade inferior a $90 \%$, provavelmente pelo uso de uma alta concentração para marcação $(125 \mu \mathrm{g} / \mathrm{mL})$, quando comparado ao nosso estudo. ${ }^{(58)}$ Para a análise in vitro por IRM utilizamos células de camundongos jovens e idosos marcadas na concentração de $50 \mu \mathrm{g} / \mathrm{mL}$ e seus respectivos controles não marcados, evidenciando um sinal hipointenso das células marcadas quando comparada aos controles, com uma redução de $39 \%$ do tempo de relaxação transversal T2 tanto para jovens e idosos (Figura 31).

A quantificação da carga de ferro internalizada nas CMN-MO foi realizada pelas técnicas NIRF, IRM e ICP-MS e NIRF (Tabela 21). A quantificação está 
de acordo com a limitação de detecção do sinal em função da sensibilidade, resolução espacial, resolução temporal de cada técnica. Alguns estudos relataram a internalização de $0,69 \pm 0,08 ;^{(137)} 1,33 \pm 0,2 ;^{(138)} 2,01 \pm 0,10 \mathrm{pg}^{(139)}$ de nanopartículas por $\mathrm{CTH}$, utilizando IRM in vitro, nosso estudo conseguiu uma internalização superior como mostrado na tabela 21 , com valores de 4,23 $\pm 0,09 p g$ Fe/CMN-MO ou $(5,32 \pm 0,11) \times 10^{4}$ NPMM/CMN-MO de camundongos jovens e nas CMN-MO de camundongos idosos $4,00 \pm 0,07 \mathrm{pg}$ Fe/CMN-MO ou $(5,03 \pm 0,81) \times 10^{4}$ NPMM/CMN-MO, obtidos pela técnica de ICP-MS. Pela técnica de IRM foram confirmados esses altos valores de internalização $3,13 \pm 0,24 \mathrm{pg}$ Fe/CMN-MO ou $(3,93 \pm 0,30) \times 10^{4}$ NPMM/CMN-MO de camundongos jovens e nas CMN-MO de camundongos idosos foram encontradas 3,08 $\pm 0,17 \mathrm{pg}$ Fe/CMN-MO ou $(3,87 \pm 0,21) \times 10^{4}$ NPMM/CMN-MO. Finalmente a carga de ferro foi quantificada por NIRF obtendo valores de 3,98 $\pm 0,16 \mathrm{pg}$ Fe/CMN-MO ou $(5,00 \pm 0,20) \times 10^{4}$ NPMM/CMN-MO de camundongos jovens e nas CMN-MO de camundongos idosos 3,98 $\pm 0,14 \mathrm{pg}$ Fe/CMN-MO ou $(5,00 \pm 0,18) \times 10^{4}$ NPMM/CMN-MO. Estes valores são maiores que os estudos citados, possivelmente por utilizarmos um pool de células da $\mathrm{MO}$, além de usarmos nanopartículas com tamanho hidrodinâmico de $38,2 \pm 0,5 \mathrm{~nm}$, diferente dos outros estudos que usaram tamanho acima dos $200 \mathrm{~nm}$ que dificulta a internalização. ${ }^{(137)}$ Também foi possível estimar o número de NPMM internalizado por CMN-MO correlacionando a carga de ferro em grandezas na ordem de $10^{4}$ NPMM.

O estudo in vivo buscou avaliar o homing e enxerto das CMN-MO de camundongos jovens e idosos, marcadas com NPMM e modificadas para a expressão de luciferase pelas técnicas de imagem de BLM, NIRF e corroboração dos resultados por azul da Prússia em tecido. O que representa uma característica desafiadora e inovadora frente à literatura, que foi mostrada pelo extenso estudo in vitro e comparado com os resultados da revisão sistemática, que não descreveu em nenhum estudo o uso de agentes de rastreamento multimodais na avaliação do homing e enxerto das CTH em modelo de TMO. ${ }^{(91)}$

A avaliação aguda do transplante por imagem de NIRF indicou que após 24 horas da administração das células, foi possível observar o sinal de FL distribuído por todo corpo dos camundongos semelhante ao estudo de Ushiki et al. ${ }^{(83)}$ Após a realização da imagem in vivo os animais foram eutanasiados e os órgãos coletados para realização de imagens ex vivo onde ficou evidenciado que o sinal de NIRF estava presente nos principais órgãos incluindo locais de interesse para a 
hematopoiese como $\mathrm{MO}$ e baço, esse resultado pode ser corroborado pela analise histológica que evidenciou em azul o ferro contido nas NPMM em quase tecidos analisados (exceto no intestino e cérebro) com acúmulo acentuado no baço e na MO (tíbia), semelhante aos achados de Maxwell et al. ${ }^{(140)}$ Outros estudos que buscaram avaliar a migração aguda da $\mathrm{CTH}$ para a $\mathrm{MO}$ por meio de técnicas de imagem molecular (PET, NIRF e IRM), também conseguiram visualizar as células transplantadas no animal receptor na região do baço e na $\mathrm{MO}$, além de outros órgãos, indicando que o homing é um processo rápido e que parte das células vão para outros órgãos além daqueles que promovem a hematopoiese. ${ }^{(58,83,114,141)}$

Não foi possível realizar a avaliação do homing das células transplantadas para a MO por imagem de BLM, porém técnica de BLM possibilitou acompanhar o enxerto dos animais por todo período de análise, conseguimos obter um sinal na ordem de $2 \times 10^{8}$ fótons/s nos receptores de células de jovens e idosos no dia 11, esse sinal aumentou com o passar do tempo obtendo seu pico de maior intensidade no dia 30 para receptores de células idosas $\left(7,88 \pm 2,61 \times 10^{8}\right.$ fótons/s) e em 35 dias para receptores de células jovens $\left(10,18 \pm 2,35 \times 10^{8}\right.$ fótons/s), a partir desse pico o sinal começou a decair se estabilizando no dia 85, com sinal na ordem de aproximadamente $10^{8}$ fótons/s até o fim da análise em 120 dias. O padrão de sinal de BLM até a do dia 83 foi compatível com a reconstituição hematopoiética analisada por hemograma, onde verificamos uma resposta do enxerto com um grande número de células maduras na circulação no dia 30, provavelmente esse aumento seja reflexo do enxerto tentando a restabelecer a função da medula produzindo células em grande quantidade. ${ }^{(142)} \mathrm{Em}$ seguida na análise de 60 dias obtivemos redução nos valores de leucócitos, semelhante a redução na intensidade do sinal de BLM, entretanto, nas análises seguintes o número de leucócitos aumentou enquanto o sinal de BLM diminuiu até o final da análise.

Esses resultados talvez indiquem o reestabelecimento da hematopoese por CTH do receptor que não foram destruídas no processo de $\mathrm{ICl}$ e que agora estão participando novamente da produção de células sanguíneas nos indivíduos receptores. ${ }^{(143)}$ Paralelamente a isso, o sinal de BLM do nosso estudo foi semelhante ao estudo de Cao et al. ${ }^{(82)}$ Que obteve uma curva com tendência parecida quando transplantou CTH-CP e observou uma diminuição na intensidade de sinal a partir do $60^{\circ}$ dia até o final da análise. Essa associação entre a sobrevivência de CTH no hospedeiro após a ICl mais transplante de progenitores e CTH-LP pode explicar a 
recuperação de células nucleadas em direção a valores normais, mas com decaimento do sinal de BLM. Infelizmente nosso estudo não conseguiu diferenciar as populações celulares transplantadas das próprias do hospedeiro, o que traria dados que possibilitariam um melhor entendimento desse fenômeno. ${ }^{(113)}$

A análise por hemograma mostrou uma diferença na frequência de leucócitos circulantes, camundongos receptores de células jovens tiveram maior número de granulócitos circulando nas duas primeiras análises hematológicas, a partir daí linfócitos foram a principal tipo celular entre ou leucócitos, padrão típico para camundongos. ${ }^{(144)}$ Enquanto receptores de células idosas tiveram a predominância de granulócitos por toda análise, essa diferenciação enviesada para a linhagem mieloide é característica do envelhecimento das $\mathrm{CTH}$, o que também acarreta a redução de diferenciação em linhagem linfoide. ${ }^{(39)}$ Esse resultado é compatível com a observação de que o sistema imune adaptativo (mediado em grande parte, pelo sistema linfoide) diminui a eficácia imunológica em idosos. ${ }^{(145,146)}$

A técnica de BLM não permitiu a visualização das células nos primeiros dias após o transplante, porém permitiu acompanhar o enxerto do $11^{\circ}$ ao $140^{\circ}$ dia após o transplante. A BLM possibilita um tempo maior de avaliação, por permitir o acompanhamento das células que se diferenciaram a partir das células transplantadas. ${ }^{\left({ }^{(2)}\right)}$ Essa avaliação concomitante, utilizando NIRF para a migração aguda e BLM no acompanhamento crônico, mostra a importância da complementação de duas ou mais técnicas para avaliação de processos biológicos in vivo de forma não invasiva. ${ }^{147)}$ Pela característica magnética da NPMM ela também permitiria a realização de imagem de IRM. ${ }^{(56-58)}$ Entretanto, nós não dispúnhamos do equipamento necessário para a realização dessas imagens. Outra possibilidade para potencializar o poder de rastreamento da NPMM seria com a adição de um radiotraçador que poderia trazer mais dados sobre a migração aguda das CMN-MO para a MO mediante o uso de técnicas de imagem nuclear. ${ }^{(148)}$

Nossos experimentos de rastreamento de CTH in vivo em modelo de TMO não demonstraram diferenças na migração e enxerto das células provenientes de animais jovens e idosos, somente na análise por hemograma podemos verificar uma tendência de diferenciação inclinada para a linhagem mieloide nos camundongos que receberam células de animais idosos. O uso conjunto de NPMM a BLM se mostrou um candidato promissor para o rastreamento de in vivo, principalmente em modelos animais que precisam ser avaliados de maneira não invasiva, com possibilidade de 
correlacionar os resultados com dados quantitativos obtidos em análises ex vivo. Entretanto, para a análise do enxerto essa estratégia deve estar alinhada a técnicas que permitam não só quantificar, como também avaliar a qualidade do enxerto. ${ }^{(110,114,116)}$ Esses resultados demonstram uma limitação das técnicas utilizadas, para que se possam gerar dados mais robustos sobre a migração das CTH e avaliação do enxerto é de extrema importância o uso de técnicas que possam corroborar os resultados em análises ex vivo. Outra limitação do estudo foi o tempo curto de avaliação do enxerto, talvez pudéssemos evidenciar diferenças nos enxertos em experimentos com maior tempo de acompanhamento ou utilizando outros tipos celulares. 


\section{CONCLUSÕES}

1. A revisão sistemática possibilitou identificar que as técnicas de imagem de bioluminescência, fluorescência, ressonância magnética, tomografia por emissão de pósitrons e tomografia computadorizada por emissão de fóton único são as principais técnicas utilizadas no rastreamento não invasivo de células-tronco hematopoiéticas em modelo de transplante de medula óssea;

2. A caracterização das nanopartículas multimodais demostrou que elas possuem um potencial zeta positivo o que favorece sua internalização nas células, além disso, elas se mostraram estáveis nos meios utilizados e geraram pouca toxicidade celular;

3. Pela característica magnética e de dupla fluorescência das nanopartículas foi possível quantificar a internalização nas células por diversas técnicas como imagem de fluorescência no infravermelho próximo, ressonância magnética e espectrometria de massa por plasma indutivamente acoplado, sendo que a única técnica que demonstrou diferenças entre células de animais jovens e idosos na mesma concentração foi à técnica de espectrometria de massa por plasma indutivamente acoplado que é padrão ouro para esse tipo de análise;

4. A imagem de fluorescência no infravermelho próximo permitiu visualizar o homing das células mononucleares da medula óssea após a realização do transplante, já a imagem de bioluminescência não permitiu rastrear as células logo após o transplante, porém permitiu acompanhar o enxerto do dia 11 até o dia 120;

5. Não foi possível evidenciar diferenças nos processos de homing e enxerto das células de animais jovens e idosos. Para buscar dados mais robustos sobre esses processos é necessário contornar limitações das técnicas utilizadas, tempo de avaliação e linhagem celular transplantada, além do uso de técnicas que possibilitem corroborar os resultados encontrados;

6. A estratégia de utilizar mais de uma técnica se mostrou fundamental, pois possibilitou rastrear as células em todos os momentos após o transplante, reduzindo as limitações das técnicas utilizadas, esse resultado ressalta a importância da construção de sondas multimodias no rastreamento de células hematopoiéticas in vivo, que também permitam confirmar os resultados em análises ex vivo por diferentes técnicas de imagem, além disso, essas avaliações devem estar associadas a técnicas que permitam avaliar a qualidade do enxerto. 


\section{REFERÊNCIAS}

1. Kondo M, Weissman IL, Akashi K. Identification of clonogenic common lymphoid progenitors in mouse bone marrow. Cell. 1997;91(5):661-72.

2. Jagannathan-Bogdan M, Zon LI. Hematopoiesis. Development. 2013;140(12):2463-7.

3. Hoffbrand AV, Moss PA, Pettit JE. Fundamentos em hematologia. Porto Alegre: Artmed; 2008. Figura 1.2 Diagrama mostrando a célula-tronco multipotente da medula óssea e as linhagens celulares que dela se originam; p. 12.

4. Dzierzak E, Bigas A. Blood development: hematopoietic stem cell dependence and independence. Cell Stem Cell. 2018;22(5):639-51.

5. McGrath KE, Frame JM, Fegan KH, Bowen JR, Conway SJ, Catherman SC, et al. Distinct sources of hematopoietic progenitors emerge before HSCs and provide functional blood cells in the mammalian embryo. Cell Rep. 2015;11(12):1892-904.

6. de Bruijn MF, Speck NA, Peeters MC, Dzierzak E. Definitive hematopoietic stem cells first develop within the major arterial regions of the mouse embryo. EMBO J. 2000;19(11):2465-74.

7. Yucel D, Kocabas F. Developments in hematopoietic stem cell expansion and gene editing technologies. In: Turksen K, editor. Cell biology and translational medicine. Manhattan, NY: Springer International Publishing; 2018. v. 1, p. 103-25.

8. Kondo M, Wagers AJ, Manz MG, Prohaska SS, Scherer DC, Beilhack GF, et al. Biology of hematopoietic stem cells and progenitors: implications for clinical application. Annu Rev Immunol. 2003;21:759-806.

9. Seita J, Weissman IL. Hematopoietic stem cell: self-renewal versus differentiation. Wiley Interdiscip Rev Syst Biol Med. 2010;2(6):640-53.

10. Pinho S, Frenette PS. Haematopoietic stem cell activity and interactions with the niche. Nat Rev Mol Cell Biol. 2019;20(5):303-20.

11. Castro Jr CG, Gregianin LJ, Brunetto AL. Transplante de medula óssea e transplante de sangue de cordão umbilical em pediatria. J Pediatr (Rio J). 2001;77:345-60.

12. Copelan EA. Hematopoietic stem-cell transplantation. N Engl J Med. 2006;354(17):181326.

13. Broxmeyer HE, Douglas GW, Hangoc G, Cooper S, Bard J, English D, et al. Human umbilical cord blood as a potential source of transplantable hematopoietic stem/progenitor cells. Proc Natl Acad Sci USA. 1989;86(10):3828-32.

14. Rhodes B, Anderlini P. Allogeneic peripheral blood stem cell collection as of 2008. Transfus Apheresis Sci. 2008;38(3):219-27.

15. Gratwohl A, Pasquini MC, Aljurf M, Atsuta Y, Baldomero H, Foeken L, et al.; Worldwide Network for Blood and Marrow Transplantation (WBMT). One million haemopoietic stem-cell transplants: a retrospective observational study. Lancet Haematol. 2015;2(3):e91-100. 
16. Gyurkocza B, Rezvani A, Storb RF. Allogeneic hematopoietic cell transplantation: the state of the art. Expert Rev Hematol. 2010;3(3):285-99.

17. Goyama S, Wunderlich M, Mulloy JC. Xenograft models for normal and malignant stem cells. Blood. 2015;125(17):2630-40.

18. Beatty PG, Dahlberg S, Mickelson EM, Nisperos B, Opelz G, Martin PJ, et al. Probability of finding HLA-matched unrelated marrow donors. Transplantation. 1988;45(4):714-8.

19. Luznik L, Jalla S, Engstrom LW, lannone R, Fuchs EJ. Durable engraftment of major histocompatibility complex-incompatible cells after nonmyeloablative conditioning with fludarabine, low-dose total body irradiation, and posttransplantation cyclophosphamide. Blood. 2001;98(12):3456-64.

20. Bashey A, Solomon SR. T-cell replete haploidentical donor transplantation using posttransplant CY: an emerging standard-of-care option for patients who lack an HLA-identical sibling donor. Bone Marrow Transplant. 2014;49(8):999-1008.

21. Aslam HM, lqbal SM, Shaikh H, Faizee FA, Merchant AA, Shaheen M, et al. Haploidentical stem cell transplantation: a gateway to infrequent availability of HLA-matched related donors. Case Rep Med. 2018;2018:2573657.

22. Pinho VF. Características clínicas e complicações do transplante haploidêntico com ciclofosfamida pós-transplante: implicações para a Enfermagem. Rev Bras Cancerol. 2020;66(1):1-12.

23. Lee SJ, Nguyen TD, Onstad L, Bar M, Krakow EF, Salit RB, et al. Success of immunosuppressive treatments in patients with chronic graft-versus-host disease. Biol Blood Marrow Transplant. 2018;24(3):555-62.

24. Passweg JR, Halter J, Bucher C, Gerull S, Heim D, Rovó A, et al. Hematopoietic stem cell transplantation: a review and recommendations for follow-up care for the general practitioner. Swiss Med Wkly. 2012;142:w13696.

25. Ferrara JL, Levine JE, Reddy P, Holler E. Graft-versus-host disease. Lancet. 2009;373(9674):1550-61.

26. McDonald-Hyman C, Turka LA, Blazar BR. Advances and challenges in immunotherapy for solid organ and hematopoietic stem cell transplantation. Sci Transl Med. 2015;7(280):280rv2.

27. Billingham RE, Brent L. Quantitative Studies on Tissue Transplantation Immunity. IV. Induction of Tolerance in Newborn Mice and Studies on the Phenomenon of Runt Disease. Philos Trans R Soc Lond B Biol Sci. 1959;242(694):439-77.

28. Billingham RE. The biology of graft-versus-host reactions. Harvey Lect. 1966-1967;62:2178.

29. Shlomchik WD. Graft-versus-host disease. Nat Rev Immunol. 2007;7(5):340-52.

30. Schroeder MA, DiPersio JF. Mouse models of graft-versus-host disease: advances and limitations. Dis Model Mech. 2011;4(3):318-33.

31. Bouzas LF, Silva MM, Tavares RC, Moreira MC, Correa ME, Funke VA, et al. Diretrizes para o diagnóstico, classificação, profilaxia e tratamento da doença enxerto contra hospedeiro crônica. Rev Bras Hematol Hemoter. 2010;32(Supl 1):22-39. 
32. Jagasia MH, Greinix HT, Arora M, Williams KM, Wolff D, Cowen EW, et al. National Institutes of Health consensus development project on criteria for clinical trials in chronic graftversus-host disease: I. The 2014 Diagnosis and Staging Working Group report. Biol Blood Marrow Transplant. 2015;21(3):389-401.e1.

33. Liu Y, Weng W, Gao R, Liu Y. New insights for cellular and molecular mechanisms of aging and aging-related diseases: herbal medicine as potential therapeutic approach. Oxid Med Cell Longev. 2019;2019:4598167.

34. de Haan G, Lazare SS. Aging of hematopoietic stem cells. Blood. 2018;131(5):479-87.

35. López-Otín C, Blasco MA, Partridge L, Serrano M, Kroemer G. The hallmarks of aging. Cell. 2013;153(6):1194-217.

36. Paiva RM, Calado RT. Telomere dysfunction and hematologic disorders. Prog Mol Biol Transl Sci. 2014;125:133-57. Figure 6.1 Short telomeres engage hematopoietic stem cells into senescense and apoptosis, impairingthe appropriate production of peripheral blood cells. p. 134.

37. Morrison SJ, Wandycz AM, Akashi K, Globerson A, Weissman IL. The aging of hematopoietic stem cells. Nat Med. 1996;2(9):1011-6.

38. Sudo K, Ema H, Morita Y, Nakauchi H. Age-associated characteristics of murine hematopoietic stem cells. J Exp Med. 2000;192(9):1273-80.

39. Khurana S. The effects of proliferation and DNA damage on hematopoietic stem cell function determine aging. Dev Dyn. 2016;245(7):739-50. Fig. 2. Increased numbers of myeloidbiased HSCs in aged mice. p. 741.

40. Boulais PE, Frenette PS. Making sense of hematopoietic stem cell niches. Blood. 2015;125(17):2621-9.

41. Szade K, Gulati GS, Chan CK, Kao KS, Miyanishi M, Marjon KD, et al. Where hematopoietic stem cells live: the bone marrow niche. Antioxid Redox Signal. 2018;29(2):191204.

42. Ehninger A, Trumpp A. The bone marrow stem cell niche grows up: mesenchymal stem cells and macrophages move in. J Exp Med. 2011;208(3):421-8. Figure 1. Location of HSC niches in trabecular boné cavities. p. 422.

43. Morikawa T, Takubo K. Hypoxia regulates the hematopoietic stem cell niche. Pflugers Arch. 2016;468(1):13-22.

44. Nombela-Arrieta C, Pivarnik G, Winkel B, Canty KJ, Harley B, Mahoney JE, et al. Quantitative imaging of haematopoietic stem and progenitor cell localization and hypoxic status in the bone marrow microenvironment. Nat Cell Biol. 2013;15(5):533-43.

45. Morrison SJ, Scadden DT. The bone marrow niche for haematopoietic stem cells. Nature. 2014;505(7483):327-34.

46. Crane GM, Jeffery E, Morrison SJ. Adult haematopoietic stem cell niches. Nat Rev Immunol. 2017;17(9):573-90. 
47. Lampreia FP, Carmelo JG, Anjos-Afonso F. Notch signaling in the regulation of hematopoietic stem cell. Curr Stem Cell Rep. 2017;3(3):202-9.

48. Bhattacharya D, Czechowicz A, Ooi AG, Rossi DJ, Bryder D, Weissman IL. Niche recycling through division-independent egress of hematopoietic stem cells. J Exp Med.

2009;206(12):2837-50.

49. Lapidot T, Dar A, Kollet O. How do stem cells find their way home? Blood. 2005;106(6):1901-10.

50. Ratajczak MZ, Suszynska M. Emerging strategies to enhance homing and engraftment of hematopoietic stem cells. Stem Cell Rev Rep. 2016;12(1):121-8.

51. Palomino DC, Marti LC. Chemokines and immunity. einstein (São Paulo). 2015;13(3):46973.

52. Zou YR, Kottmann AH, Kuroda M, Taniuchi I, Littman DR. Function of the chemokine receptor CXCR4 in haematopoiesis and in cerebellar development. Nature.

1998;393(6685):595-9.

53. Nagasawa T, Hirota S, Tachibana K, Takakura N, Nishikawa S, Kitamura Y, et al. Defects of B-cell lymphopoiesis and bone-marrow myelopoiesis in mice lacking the CXC chemokine PBSF/SDF-1. Nature. 1996;382(6592):635-8.

54. Cahalan MD, Parker I, Wei SH, Miller MJ. Two-photon tissue imaging: seeing the immune system in a fresh light. Nat Rev Immunol. 2002;2(11):872-80.

55. Lee HW, Gangadaran P, Kalimuthu S, Ahn BC. Advances in Molecular Imaging Strategies for In Vivo Tracking of Immune Cells. BioMed Res Int. 2016;2016:1946585.

56. Bengtsson NE, Kim S, Lin L, Walter GA, Scott EW. Ultra-high-field MRI real-time imaging of HSC engraftment of the bone marrow niche. Leukemia. 2011;25(8):1223-31.

57. Niemeyer M, Oostendorp RA, Kremer M, Hippauf S, Jacobs VR, Baurecht H, et al. Noninvasive tracking of human haemopoietic CD34(+) stem cells in vivo in immunodeficient mice by using magnetic resonance imaging. Eur Radiol. 2010;20(9):2184-93.

58. Sweeney SK, Manzar GS, Zavazava N, Assouline JG. Tracking embryonic hematopoietic stem cells to the bone marrow: nanoparticle options to evaluate transplantation efficiency. Stem Cell Res Ther. 2018;9(1):204.

59. da Silva HR, Mamani JB, Nucci MP, Nucci LP, Kondo AT, Fantacini DM, et al. Triple-modal imaging of stem-cells labeled with multimodal nanoparticles, applied in a stroke model. World $\mathrm{J}$ Stem Cells. 2019;11(2):100-23.

60. Choy G, Choyke P, Libutti SK. Current advances in molecular imaging: noninvasive in vivo bioluminescent and fluorescent optical imaging in cancer research. Mol Imaging.

2003;2(4):303-12.

61. Duinhouwer LE, van Rossum BJ, van Tiel ST, van der Werf RM, Doeswijk GN, Haeck JC, et al. Magnetic resonance detection of CD34+ cells from umbilical cord blood using a 19F label. PLoS One. 2015;10(9):e0138572.

62. Webster TJ. Nanomedicine: what's in a definition? Int J Nanomedicine. 2006;1(2):115-6. 
63. Bardhan R, Lal S, Joshi A, Halas NJ. Theranostic nanoshells: from probe design to imaging and treatment of cancer. Acc Chem Res. 2011;44(10):936-46.

64. Davis ME, Chen ZG, Shin DM. Nanoparticle therapeutics: an emerging treatment modality for cancer. Nat Rev Drug Discov. 2008;7(9):771-82.

65. Chen X, Gambhir SS, Cheon J. Theranostic nanomedicine. Acc Chem Res. 2011;44(10):841.

66. Chou LY, Ming K, Chan WC. Strategies for the intracellular delivery of nanoparticles. Chem Soc Rev. 2011;40(1):233-45.

67. Itani R, Al Faraj A. siRNA conjugated nanoparticles-a next generation strategy to treat lung cancer. Int J Mol Sci. 2019;20(23):6088.

68. Accomasso L, Gallina C, Turinetto V, Giachino C. Stem cell tracking with nanoparticles for regenerative medicine purposes: an overview. Stem Cells Int. 2016;2016:7920358.

69. Dulińska-Litewka J, Łazarczyk A, Hałubiec P, Szafrański O, Karnas K, Karewicz A. Superparamagnetic iron oxide nanoparticles-current and prospective medical applications. Materials (Basel). 2019;12(4):617.

70. Khafaji M, Zamani M, Golizadeh M, Bavi O. Inorganic nanomaterials for chemo/photothermal therapy: a promising horizon on effective cancer treatment. Biophys Rev. 2019;11(3):335-52.

71. Jasmin, de Souza GT, Louzada RA, Rosado-de-Castro PH, Mendez-Otero R, Campos de Carvalho AC. Tracking stem cells with superparamagnetic iron oxide nanoparticles: perspectives and considerations. Int J Nanomedicine. 2017;12:779-93.

72. Muthiah M, Park IK, Cho CS. Surface modification of iron oxide nanoparticles by biocompatible polymers for tissue imaging and targeting. Biotechnol Adv. 2013;31(8):1224-36.

73. Bakhtiary Z, Saei AA, Hajipour MJ, Raoufi M, Vermesh O, Mahmoudi M. Targeted superparamagnetic iron oxide nanoparticles for early detection of cancer: possibilities and challenges. Nanomedicine. 2016;12(2):287-307.

74. Wahajuddin AS, Arora S. Superparamagnetic iron oxide nanoparticles: magnetic nanoplatforms as drug carriers. Int J Nanomedicine. 2012;7:3445-71.

75. Alvarim LT, Nucci LP, Mamani JB, Marti LC, Aguiar MF, Silva HR, et al. Therapeutics with SPION-labeled stem cells for the main diseases related to brain aging: a systematic review. Int J Nanomedicine. 2014;9:3749-70.

76. Kuhn DA, Vanhecke D, Michen B, Blank F, Gehr P, Petri-Fink A, et al. Different endocytotic uptake mechanisms for nanoparticles in epithelial cells and macrophages. Beilstein $\mathrm{J}$ Nanotechnol. 2014;5:1625-36.

77. Mamani JB, Malheiros JM, Cardoso EF, Tannús A, Silveira PH, Gamarra LF. In vivo magnetic resonance imaging tracking of $\mathrm{C} 6$ glioma cells labeled with superparamagnetic iron oxide nanoparticles. einstein (São Paulo). 2012;10(2):164-70.

78. Mankoff DA. A definition of molecular imaging. J Nucl Med. 2007;48(6):18N, 21N. 
79. Kim J, Lee N, Hyeon T. Recent development of nanoparticles for molecular imaging. Philos Trans- Royal Soc, Math Phys Eng Sci. 2017;375(2107):20170022.

80. Hong $\mathrm{H}$, Yang $\mathrm{Y}$, Zhang $\mathrm{Y}$, Cai W. Non-invasive cell tracking in cancer and cancer therapy. Curr Top Med Chem. 2010;10(12):1237-48. Fig. (1). Many imaging labels and techniques have been used to label cells and track them in vivo. Some involve direct labeling of the cells while others require genetic modification of the cells. p. 1238.

81. Kim MH, Lee YJ, Kang JH. Stem cell monitoring with a direct or indirect labeling method. Nucl Med Mol Imaging. 2016;50(4):275-83.

82. Cao YA, Wagers AJ, Beilhack A, Dusich J, Bachmann MH, Negrin RS, et al. Shifting foci of hematopoiesis during reconstitution from single stem cells. Proc Natl Acad Sci USA. 2004;101(1):221-6.

83. Ushiki T, Kizaka-Kondoh S, Ashihara E, Tanaka S, Masuko M, Hirai H, et al. Noninvasive tracking of donor cell homing by near-infrared fluorescence imaging shortly after bone marrow transplantation. PLoS One. 2010;5(6):e11114.

84. Wu M, Shu J. Multimodal molecular imaging: current status and future directions. Contrast Media Mol Imaging. 2018;2018:1382183.

85. Fernández-Friera L, García-Álvarez A, Ibáñez B. Imagining the future of diagnostic imaging. Rev Esp Cardiol (Engl Ed). 2013;66(2):134-43.

86. Hage MC, Iwasaki M. Imagem por ressonância magnética: princípios básicos. Cienc Rural. 2009;39:1275-83.

87. Mazzola AA. Ressonância magnética: princípios de formação da imagem e aplicações em imagem funcional. Rev Bras Fis Med. 2009;3(1):117-29.

88. Grover VP, Tognarelli JM, Crossey MM, Cox IJ, Taylor-Robinson SD, McPhail MJ. Magnetic resonance imaging: principles and techniques: lessons for clinicians. J Clin Exp Hepatol. 2015;5(3):246-55.

89. Contreras LF. Espectroscopia por ressonância magnética nuclear localizada: projeto e implementação [dissertação]. São Paulo: Universidade de São Paulo; 2001.

90. Shan L. Superparamagnetic iron oxide nanoparticles (SPION) stabilized by alginate. 2009 [updated 2009 Nov 30 cited 2021 Apr 20]. In: Molecular Imaging and Contrast Agent Database (MICAD) [Internet]. Bethesda (MD): National Center for Biotechnology Information (US); 20042013. Available from: https://www.ncbi.nlm.nih.gov/books/NBK23636/

91. Oliveira FA, Nucci MP, Filgueiras IS, Ferreira JM, Nucci LP, Mamani JB, et al. Noninvasive tracking of hematopoietic stem cells in a bone marrow transplant model. Cells. 2020;9(4):939.

92. Nucci MP, Filgueiras IS, Ferreira JM, de Oliveira FA, Nucci LP, Mamani JB, et al. Stem cell homing, tracking and therapeutic efficiency evaluation for stroke treatment using nanoparticles: a systematic review. World J Stem Cells. 2020;12(5):381-405. Table 1. Molecular imaging modalities. p. 384.

93. Fiz F, Marini C, Campi C, Massone AM, Podestà M, Bottoni G, et al. Allogeneic cell transplant expands bone marrow distribution by colonizing previously abandoned areas: an FDG PET/CT analysis. Blood. 2015;125(26):4095-102. 
94. Habringer S, Lapa C, Herhaus P, Schottelius M, Istvanffy R, Steiger K, et al. Dual targeting of acute leukemia and supporting niche by CXCR4-Directed theranostics. Theranostics. 2018;8(2):369-83.

95. Marini C, Podestà M, Massollo M, Capitanio S, Fiz F, Morbelli S, et al. Intrabone transplant of cord blood stem cells establishes a local engraftment store: a functional PET/FDG study. J Biomed Biotechnol. 2012;2012:767369.

96. Williams KM, Holter-Chakrabarty J, Lindenberg L, Duong Q, Vesely SK, Nguyen CT, et al. Imaging of subclinical haemopoiesis after stem-cell transplantation in patients with haematological malignancies: a prospective pilot study. Lancet Haematol. 2018;5(1):e44-52.

97. Zheng Y, Huang J, Zhu T, Li R, Wang Z, Ma F, et al. Stem cell tracking technologies for neurological regenerative medicine purposes. Stem Cells Int. 2017;2017:2934149.

98. Deshpande N, Pysz MA, Willmann JK. Molecular ultrasound assessment of tumor angiogenesis. Angiogenesis. 2010;13(2):175-88.

99. Abbas F, Wu JC, Gambhir SS, Rodriguez-Porcel M. Molecular imaging of stem cells. StemJournal. 2019;1:27-46.

100. Livieratos L. Basic principles of SPECT and PET imaging. In: Fogelman I, Gnanasegaran $\mathrm{G}$, van der Wall H, editors. Radionuclide and hybrid bone imaging. Berlin, Heidelberg: Springer Berlin Heidelberg; 2012. p. 345-59.

101. Ramesh $\mathrm{CH}$, Mohanraju R. A review on bioluminescence and its applications. Int $\mathrm{J}$ Lumin Appl. 2015; 5(1):45-6.

102. Ozawa T, Yoshimura H, Kim SB. Advances in fluorescence and bioluminescence imaging. Anal Chem. 2013;85(2):590-609.

103. Badr CE, Tannous BA. Bioluminescence imaging: progress and applications. Trends Biotechnol. 2011;29(12):624-33. Figure 1. Bioluminescence reactions of Fluc, Rluc and Gluc. p. 625.

104. Wang X, Rosol M, Ge S, Peterson D, McNamara G, Pollack H, et al. Dynamic tracking of human hematopoietic stem cell engraftment using in vivo bioluminescence imaging. Blood. 2003;102(10):3478-82.

105. Liang Y, Van Zant G, Szilvassy SJ. Effects of aging on the homing and engraftment of murine hematopoietic stem and progenitor cells. Blood. 2005;106(4):1479-87.

106. Mezzanotte L, van't Root M, Karatas H, Goun EA, Löwik CW. In vivo molecular bioluminescence imaging: new tools and applications. Trends Biotechnol. 2017;35(7):640-52.

107. Lee HW, Gangadaran P, Kalimuthu S, Ahn BC. Advances in molecular imaging strategies for in vivo tracking of immune cells. BioMed Res Int. 2016;2016:1946585.

108. Evans TA, Barkauskas DS, Silver J. Intravital imaging of immune cells and their interactions with other cell types in the spinal cord: experiments with multicolored moving cells. Exp Neurol. 2019;320:112972.

109. Lopez D, Lin L, Monaghan JR, Cogle CR, Bova FJ, Maden M, et al. Mapping hematopoiesis in a fully regenerative vertebrate: the axolotl. Blood. 2014;124(8):1232-41. 
110. Parada-Kusz M, Penaranda C, Hagedorn EJ, Clatworthy A, Nair AV, Henninger JE, et al. Generation of mouse-zebrafish hematopoietic tissue chimeric embryos for hematopoiesis and host-pathogen interaction studies. Dis Model Mech. 2018;11(11):dmm034876.

111. Khamis RY, Woollard KJ, Hyde GD, Boyle JJ, Bicknell C, Chang SH, et al. Near Infrared Fluorescence (NIRF) molecular imaging of oxidized LDL with an autoantibody in experimental atherosclerosis. Sci Rep. 2016;6(1):21785.

112. Liberati A, Altman DG, Tetzlaff J, Mulrow C, Gøtzsche PC, loannidis JP, et al. The PRISMA statement for reporting systematic reviews and meta-analyses of studies that evaluate health care interventions: explanation and elaboration. PLoS Med. 2009;6(7):e1000100.

113. Andrade J, Ge S, Symbatyan G, Rosol MS, Olch AJ, Crooks GM. Effects of sublethal irradiation on patterns of engraftment after murine bone marrow transplantation. Biol Blood Marrow Transplant. 2011;17(5):608-19.

114. Asiedu KO, Koyasu S, Szajek LP, Choyke PL, Sato N. Bone marrow cell trafficking analyzed by $89 \mathrm{Zr}$-oxine positron emission tomography in a murine transplantation model. Clin Cancer Res. 2017;23(11):2759-68.

115. Astuti Y, Kramer AC, Blake AL, Blazar BR, Tolar J, Taisto ME, et al. A functional bioluminescent zebrafish screen for enhancing hematopoietic cell homing. Stem Cell Reports. 2017;8(1):177-90.

116. Faivre L, Chaussard M, Vercellino L, Vanneaux V, Hosten B, Teixera K, et al. 18F-FDG labelling of hematopoietic stem cells: dynamic study of bone marrow homing by PET-CT imaging and impact on cell functionality. Curr Res Transl Med. 2016;64(3):141-8.

117. Hamilton N, Sabroe I, Renshaw SA. A method for transplantation of human HSCs into zebrafish, to replace humanised murine transplantation models [version 1; referees: 2 approved]. F1000 Res. 2018;7:594.

118. Lange S, Steder A, Killian D, Knuebel G, Sekora A, Vogel H, et al. Engraftment efficiency after intra-bone marrow versus intravenous transplantation of bone marrow cells in a canine nonmyeloablative dog leukocyte antigen-identical transplantation model. Biol Blood Marrow Transplant. 2017;23(2):247-54.

119. Lin Y, Cheung P, Roth JC, Wilson DL, Gerson SL. Imaging stem cell-derived persistent foci after in vivo selection of lentiviral MGMT-P140K transduced murine bone marrow cells. Mol Ther. 2011;19(7):1342-52.

120. Massollo M, Podestà M, Marini C, Morbelli S, Cassanelli C, Pinto V, et al. Contact with the bone marrow microenvironment readdresses the fate of transplanted hematopoietic stem cells. Exp Hematol. 2010;38(10):968-77.

121. Ohmori T, Kashiwakura Y, Ishiwata A, Madoiwa S, Mimuro J, Furukawa Y, et al. Vinculin is indispensable for repopulation by hematopoietic stem cells, independent of integrin function. $J$ Biol Chem. 2010;285(41):31763-73.

122. Pantin JM, Hoyt RF Jr, Aras O, Sato N, Chen MY, Hunt T, et al. Optimization of intrabone delivery of hematopoietic progenitor cells in a swine model using cell radiolabeling with [89]zirconium. Am J Transplant. 2015;15(3):606-17. 
123. Saia M, Termanini A, Rizzi N, Mazza M, Barbieri E, Valli D, et al. AML1/ETO accelerates cell migration and impairs cell-to-cell adhesion and homing of hematopoietic stem/progenitor cells. Sci Rep. 2016;6:34957.

124. Sambuceti G, Massollo M, Marini C, Podestà M, Cassanelli C, Morbelli S, et al. Trafficking and homing of systemically administered stem cells: the need for appropriate analysis tools of radionuclide images. Q J Nucl Med Mol Imaging. 2013;57(2):207-15.

125. Staal FJ, Spaink HP, Fibbe WE. Visualizing human hematopoietic stem cell trafficking in vivo using a zebrafish xenograft model. Stem Cells Dev. 2016;25(4):360-5.

126. Steiner D, Gelovani J, Savoldo B, Robinson SN, Decker WK, Brouard N, et al. Noninvasive bioluminescent imaging demonstrates long-term multilineage engraftment of ex vivo-expanded CD34-selected umbilical cord blood cells. Stem Cells. 2009;27(8):1932-40.

127. Gratton SE, Ropp PA, Pohlhaus PD, Luft JC, Madden VJ, Napier ME, et al. The effect of particle design on cellular internalization pathways. Proc Natl Acad Sci USA.

2008;105(33):11613-8.

128. Walczyk D, Bombelli FB, Monopoli MP, Lynch I, Dawson KA. What the cell "sees" in bionanoscience. J Am Chem Soc. 2010;132(16):5761-8.

129. Tenzer S, Docter D, Kuharev J, Musyanovych A, Fetz V, Hecht R, et al. Rapid formation of plasma protein corona critically affects nanoparticle pathophysiology. Nat Nanotechnol. 2013;8(10):772-81.

130. Ali A, Zafar H, Zia M, UI Haq I, Phull AR, Ali JS, et al. Synthesis, characterization, applications, and challenges of iron oxide nanoparticles. Nanotechnol Sci Appl. 2016;9:49-67.

131. Shaikh A, Bhartiya D, Kapoor S, Nimkar H. Delineating the effects of 5-fluorouracil and follicle-stimulating hormone on mouse bone marrow stem/progenitor cells. Stem Cell Res Ther. 2016;7(1):59.

132. Troy T, Jekic-McMullen D, Sambucetti L, Rice B. Quantitative comparison of the sensitivity of detection of fluorescent and bioluminescent reporters in animal models. Mol Imaging. 2004;3(1):9-23.

133. Zhang SJ, Wu JC. Comparison of imaging techniques for tracking cardiac stem cell therapy. J Nucl Med. 2007;48(12):1916-9.

134. Säwen P, Eldeeb M, Erlandsson E, Kristiansen TA, Laterza C, Kokaia Z, et al. Murine HSCs contribute actively to native hematopoiesis but with reduced differentiation capacity upon aging. eLife. 2018;7:7.

135. Wierzbinski KR, Szymanski T, Rozwadowska N, Rybka JD, Zimna A, Zalewski T, et al. Potential use of superparamagnetic iron oxide nanoparticles for in vitro and in vivo bioimaging of human myoblasts. Sci Rep. 2018;8(1):3682.

136. Arbab AS, Yocum GT, Rad AM, Khakoo AY, Fellowes V, Read EJ, et al. Labeling of cells with ferumoxides-protamine sulfate complexes does not inhibit function or differentiation capacity of hematopoietic or mesenchymal stem cells. NMR Biomed. 2005;18(8):553-9.

137. Kim SJ, Lewis B, Steiner MS, Bissa UV, Dose C, Frank JA. Superparamagnetic iron oxide nanoparticles for direct labeling of stem cells and in vivo MRI tracking. Contrast Media Mol Imaging. 2016;11(1):55-64. 
138. Thu MS, Bryant LH, Coppola T, Jordan EK, Budde MD, Lewis BK, et al. Self-assembling nanocomplexes by combining ferumoxytol, heparin and protamine for cell tracking by magnetic resonance imaging. Nat Med. 2012;18(3):463-7.

139. Arbab AS, Yocum GT, Kalish H, Jordan EK, Anderson SA, Khakoo AY, et al. Efficient magnetic cell labeling with protamine sulfate complexed to ferumoxides for cellular MRI. Blood. 2004;104(4):1217-23.

140. Maxwell DJ, Bonde J, Hess DA, Hohm SA, Lahey R, Zhou P, et al. Fluorophoreconjugated iron oxide nanoparticle labeling and analysis of engrafting human hematopoietic stem cells. Stem Cells. 2008;26(2):517-24.

141. Short C, Lim HK, Tan J, O'Neill HC. Targeting the spleen as an alternative site for hematopoiesis. BioEssays. 2019;41(5):e1800234.

142. Miller SC. Hematopoietic reconstitution of irradiated, stem cell-injected mice: early dynamics of restoration of the cell lineages of the spleen and bone marrow. J Hematother Stem Cell Res. 2002;11(6):965-70.

143. Montfort MJ, Olivares CR, Mulcahy JM, Fleming WH. Adult blood vessels restore host hematopoiesis following lethal irradiation. Exp Hematol. 2002;30(8):950-6.

144. O'Connell KE, Mikkola AM, Stepanek AM, Vernet A, Hall CD, Sun CC, et al. Practical murine hematopathology: a comparative review and implications for research. Comp Med. 2015;65(2):96-113.

145. Rossi DJ, Bryder D, Zahn JM, Ahlenius H, Sonu R, Wagers AJ, et al. Cell intrinsic alterations underlie hematopoietic stem cell aging. Proc Natl Acad Sci USA.

2005;102(26):9194-9.

146. Mejia-Ramirez E, Florian MC. Understanding intrinsic hematopoietic stem cell aging. Haematologica. 2020;105(1):22-37.

147. w Thin M, Allan H, Bofinger R, Kostelec TD, Guillaume S, Connell JJ, et al. Multi-modal imaging probe for assessing the efficiency of stem cell delivery to orthotopic breast tumours. Nanoscale. 2020;12(31):16570-85.

148. Belderbos S, González-Gómez MA, Cleeren F, Wouters J, Piñeiro Y, Deroose CM, et al. Simultaneous in vivo PET/MRI using fluorine-18 labeled Fe3O4@Al(OH)3 nanoparticles: comparison of nanoparticle and nanoparticle-labeled stem cell distribution. EJNMMI Res. 2020;10(1):73. 


\section{Abstract}

Introduction: Bone marrow transplantation is a therapeutic procedure used as a treatment for several hematological disease given the ability of the hematopoietic stem cell to self-renew and differentiate itself in the different lineages of the hematopoietic tissue. The aging of the hematopoietic stem cell is linked to the reduced ability to graft and differentiate into hematopoietic strains after transplantation. In addition, the lack of consistent data in vivo experiments is a barrier to allow data generating on graft kinetics and hematopoietic stem cell migration in a noninvasive way that can improve the transplant and graft process. The labeling of cells with nanoparticles or the transduction with luciferase combined with molecular imaging techniques can contribute to a better understanding of their dynamics after transplantation. Purpose: To evaluate the homing of hematopoietic stem cells from young and aged mice labeled with multimodal nanoparticles and modified for luciferase expression by molecular imaging techniques in a bone marrow transplantation model. Methods: A systematic review of the literature was carried out to search for the best strategies to perform noninvasive screening for hematopoietic stem cells in a bone marrow transplantation model. Subsequently, we performed the physicochemical characterization of multimodal nanoparticles (magnetic and fluorescent properties) regarding their hydrodynamic size, stability, zeta potential, and optical properties. After this characterization, we labelled the bone marrow mononuclear cells of young and aged mice with nanoparticles and transfect them for luciferase expression to conduct feasibility, sensitivity, and quantity of internalization analyzes by magnetic resonance imaging, near-infrared fluorescence imaging, bioluminescence imaging, and inductively coupled plasma mass spectrometry techniques. Once labeled, cells were transplanted and evaluated by molecular imaging and histology techniques. Results: The literature review indicated that the imaging techniques of bioluminescence, fluorescence, magnetic resonance, positron emission tomography, and single-photon emission computed tomography are the most used for noninvasive tracking of hematopoietic stem cells. The multimodal nanoparticles characterization showed a positive zeta $(34.9 \mathrm{mV})$ that favors their internalization into cells that have a negative charge. The nanoparticles were stable in the culture medium used during the labeling, and it avoided the formation of agglomerates that could compromise their internalization in the cells. After labeling in the highest concentration 
of nanoparticles we also observed that cells remained $95 \%$ viable compared with the unlabeled control. The detection of the near-infrared fluorescence imaging signal was also allowed in the order of $10^{8}$ in all concentrations and a hypointense signal in magnetic resonance imaging. The use of nanoparticles also enabled the quantification of nanoparticles internalized by cells by various techniques (magnetic resonance imaging, near-infrared fluorescence imaging, and inductively coupled plasma mass spectrometry). When the groups and multimodal nanoparticles concentrations were compared only the quantification of iron by inductively coupled plasma mass spectrometry showed a significant difference between young and aged mice in the same multimodal nanoparticles concentration. The remaining techniques showed significant differences between multimodal nanoparticles concentrations as in the order of picograms of iron per cell as well as in the number of nanoparticles/cell in the order of $10^{4}$, however, there were no differences between groups. In the in vivo study, we observed a result that was corroborated by those of ex vivo bioluminescence, and histological analysis by using a near-infrared fluorescence imaging of cells labeled with multimodal nanoparticles 24-hours after transplantation in all analyzed organs, particularly in hematopoietic organs (spleen and bone marrow). The bioluminescence imaging evaluation allowed us to monitor the grafting from the 11th day to the 120th day. Conclusion: The systematic review of the literature enabled to direct our study towards a better approach of all aspects regarding the noninvasive tracking model after bone marrow transplantation, especially in terms of evaluation and parameters. The nanoparticles used did not significantly change cell viability and allowed quantification by various techniques. These results generate an advance in the homing/tracking of hematopoietic stem cells by various molecular imaging techniques and corroborate the migration by histology of target organs.

Keywords: Nanoparticles; Bioluminescence imaging [not in DeCS]; Fluorescence imaging [not in DeCS]; Magnetic resonance imaging; Hematopoietic stem cells; Bone marrow transplantation; Molecular imaging 